ZEITSCHRIFT FÜR FEMINISTISCHE POLITIKWISSENSCHAFT

02 | 2018 27. Jg.

\title{
100 Jahre Frauenwahlrecht - und wo bleibt die Gleichheit?
}

ABElS. AHRENS. Blome 100 Jahre Frauenwahlrecht - Der UNVOLLENDETE WEg CRESS (DIS-)KONTINUITÄTEN FEMINISTISCHER REPRÄSENTATIONSKRITIK RÖHNER RELATIONALE DEMOKRATIE DAVIDSON-SCHMICH SUPPLY-SIDE HURDLES TO GENDER-EQUAL REPRESENTATION JENICHEN POLITISCHE UNTERREPRÄSENTATION von Musliminnen MUSHABEN The ReLuctant Feminist Angela MERKEL KLETZING HaNDLUNGSRESSOURCEN, MÄNNLICHE STANDARDS und BürgermeisterinNen FIIG Gendered Distribution of SeAtS IN Danish PaRliamentaRy CommitTEes 


\section{Jahre Frauenwahlrecht - und wo bleibt die Gleichheit?}





\section{INHALT}

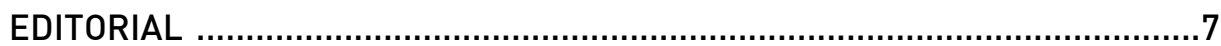

100 JAHRE FRAUENWAHLRECHT - UND WO BLEIBT DIE GLEICHHEIT? ....... 9

GABRIELE ABELS. PETRA AHRENS. AGNES BLOME

100 Jahre Frauenwahlrecht - der unvollendete Weg zu geschlechtergerechter

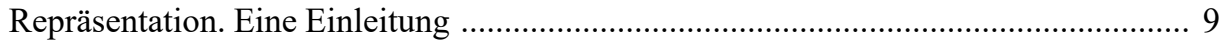

\section{ANNE CRESS}

Feministische Repräsentationskritik: (Dis-)Kontinuitäten von den ersten

deutschen Frauenbewegungen bis in die Gegenwart

CARA RÖHNER

Relationale Demokratie. Das verfassungsrechtliche Demokratieprinzip und gerechte Staatlichkeit in Deutschland

LOUISE K. DAVIDSON-SCHMICH

Addressing Supply-Side Hurdles to Gender-Equal Representation in Germany 53

ANNE JENICHEN

Muslimische Politikerinnen in Deutschland: Erfolgsmuster und Hindernisse politischer Repräsentation 70

JOYCE MARIE MUSHABEN

The Reluctant Feminist: Angela Merkel and the Modernization of Gender

Politics in Germany 83

UTA KLETZING

Ausschluss trotz Einschluss. Ungleiche Handlungsressourcen von

Bürgermeisterinnen und Bürgermeistern 95

CHRISTINA FIIG

Gendered Segregation in Danish Standing Parliamentary Committees

$1990-2015$ 
FORUM

ALEX WISCHNEWSKI

Femi(ni)zide in Deutschland - ein Perspektivwechsel

\section{ISABELLA SOPHIE ROTINO}

Der Zugang zu Schutz für geflüchtete Menschen: eine feministische Analyse

PERSSON PERRY BAUMGARTINGER

Trans Studies \& Feminismen - Reibungen, Brüche ... und Allianzen?

TAGESPOLITIK

ANDREA PETŐ

Without Remedy: Lessons Learned from a Gendered Analysis of the 2018

Hungarian General Elections

JASMIN KASSAI. HANNA LICHTENBERGER

Gewalt an Frauen auf der Flucht

MECHTHILD EXO

Afrin, Frauenrevolution und die Jineolojî 1623

NEUES AUS LEHRE UND FORSCHUNG

Kurznachrichten

JANA GÜNTHER

Studium prekär

DAVID KERGEL. BIRTE HEIDKAMP-KERGEL

Strategien für eine gender- und diversitätssensible Hochschuldidaktik 184

REZENSIONEN 162

HELIN RUF-UÇAR

Hürcan Aslı Aksoy (Hg.): Patriarchat im Wandel. Frauen und Politik in der Türkei 191

KARIN LOHR

Maria Funder (Hg.): Neo-Institutionalismus - Revisited. Bilanz und

Weiterentwicklungen aus Sicht der Geschlechterforschung 194 


\section{CARINA MAIER}

Alexandra Scheele, Stefanie Wöhl (Hg.): Feminismus und Marxismus

ANNE CRESS

Petra Ahrens: Actors, Institutions, and the Making of EU Gender

Equality Programs

\section{BRIGITTE TEMEL}

Heike Mauer: Intersektionalität und Gouvernementalität. Die Regierung von Prostitution in Luxemburg

\section{MAREIKE GEBHARDT}

Gerald Posselt, Tatjana Schönwälder-Kuntze, Sergej Seitz (Hg.):

Judith Butlers Philosophie des Politischen. Kritische Lektüren

ANNETTE HENNINGER

Antifeminismus: Kontextualisierung, Historisierung und Theoretisierung eines aktuellen Phänomens (Sammelrezension)

Call for Papers: Heft 2/2019 der Femina Politica: Umkämpfte Solidaritäten (Arbeitstitel) 



\section{EDITORIAL}

\section{Liebe Leser_innen,}

vor 100 Jahren gelang den ersten Frauenbewegungen ein entscheidender Erfolg. Ihre vielfältigen, hartnäckigen, langen Kämpfe führten dazu, dass 1918 in Österreich und Deutschland das Frauenwahlrecht eingeführt wurde. Frauen konnten damit Anfang 1919 bei den Wahlen zur Deutschen bzw. Österreichischen Nationalversammlung erstmalig ihre Repräsentant_innen wählen und selbst kandidieren. Seither besteht nun die Möglichkeit, dass Frauen gleichermaßen an politischen Entscheidungsprozessen partizipieren können. Was hat diese formale Möglichkeit politischer Partizipation und Gestaltung bewirkt? Wie ist es um die Repräsentation von Frauen heute bestellt?

100 Jahre nach der formalen Einführung des Frauenwahlrechtes nimmt die Femina Politica das Jubiläum zum Anlass, sich erneut mit Stand und Perspektiven der politischen Repräsentation von Frauen auseinanderzusetzen. Nachdenklich stimmen hier vor allem Befunde zur deskriptiv-quantitativen Repräsentation von Frauen, die hinsichtlich der Vertretung von Frauen in Parteien und Parlamenten eher ein Bild der Stagnation zeichnen. Auch Frauen in herausgehobenen politischen Ämtern sind - trotz mancher einzelner erfolgreicher Frauen - längst keine Normalität. Mit Blick auf die Qualität der Repräsentation bzw. die substanzielle Repräsentation wird zugleich kontroverser diskutiert, unter welchen Bedingungen feministische sowie gleichstellungs- und diversitätspolitische Fragen in der Politik Vertretung und Gehör finden. Dies gilt besonders vor dem Hintergrund, dass sich in den letzten Jahren deutliche Widerstände gegen feministische Politiken formiert haben. Nicht zuletzt angesichts des aktuellen Angriffs auf die Demokratie (siehe Femina Politica 1/2018) wird offensichtlich, dass Macht- und Herrschaftsverhältnisse nicht nur mit Blick auf die Kategorie Geschlecht problematisiert werden sollten, sondern eine herrschaftskritische, auf die Rechte aller hin orientierte Politik breiter aufgestellt sein muss.

Neben diesem thematischen Schwerpunkt öffnet das „Forum“ den Blick auf weitere geschlechterpolitisch wichtige Themen: Der Beitrag von Wischnewski beleuchtet Frauenmorde bzw. das Phänomen der Femi(ni)zide in Deutschland und gibt eine überfällige Einordnung zur Begriffskontroverse und zum Stand von gesellschaftlicher Debatte, Rechtsprechung und Forschung. Rotino analysiert - mit Blick auf geschlechtsbezogene Fluchtgründe, sogenannte sichere Herkunftsstaaten und den Familiennachzug - die Gesetzesverschärfungen im Flüchtlingsrecht und konstatiert insbesondere einen Rückschritt bei der Geschlechtergleichstellung. Der Beitrag von Baumgartinger befasst sich schließlich vor dem Hintergrund feministischer Antitrans-Politiken mit der Entstehung der Trans Studies, ihrem gesellschaftlichen Kontext, ihren theoretischen Bezügen und aktivistischen Kämpfen. 
In der Tagespolitik setzt sich Pető kritisch damit auseinander, wie derzeit in Ungarn feministische Bewegungen und die Gender-Forschung durch Akteur_innen der Anti-Gender-Bewegung diffamiert und bekämpft werden, und sich auf diese Weise der Zulauf für den Ministerpräsidenten Viktor Orbán bei den letzten Wahlen erhöht hat - ein Thema, das durch die geplante Abschaffung von Gender Studies an den Budapester Universitäten aktuell für Diskussionen und Protest sorgt. Weitere Beiträge thematisieren unterschiedliche Facetten geschlechtsspezifischer Gewalt auf der Flucht (Kassai/Lichtenberger) sowie die Aktivitäten kurdischer Frauenorganisationen um Afrin (Rojava) für den Auf- und Ausbau einer alternativen, anti-patriarchalen Gesellschaft (Exo).

Die Rubrik Neues aus Lehre und Forschung bietet neben den Kurznachrichten zum ersten einen Beitrag zur sozialen Dimension in Lehre und Forschung, der vor allem auf die prekäre Situation von Studierenden kritisch eingeht und die Studierendenfinanzierung in Deutschland näher in den Blick nimmt. Zum zweiten werden neuere Ansätze gender- und diversitätskritischer Hochschuldidaktik vorgestellt und deren Potenzial für Machtkritik, dekonstruktivistische Wissensproduktion und ein Empowerment von Studierenden herausgearbeitet.

Zum Schluss finden sich Rezensionen sowie die Rubrik Ankündigungen und Infos, die wie gewohnt Besprechungen enthalten und einen Überblick über aktuelle Neuerscheinungen geben.

Eine anregende Lektüre wünscht Ihnen und Euch die Redaktion.

Vorschau auf die nächsten Hefte (Arbeitstitel)

1/2019 Her mit der Zukunft?! Feministische und queere Utopien und die Suche nach alternativen Gesellschaftsformen

2/2019 Umkämpfte Solidaritäten 


\title{
SCHWERPUNKT
}

\section{Jahre Frauenwahlrecht - und wo bleibt die Gleichheit?}

\section{Jahre Frauenwahlrecht - der unvollendete Weg zu geschlechtergerechter Repräsentation. Eine Einleitung ${ }^{1}$}

\author{
GABRIELE ABELS. PETRA AHRENS. AGNES BLOME
}

Am 30. November 1918 erhielten Frauen in Deutschland das Wahlrecht. Das Reichswahlgesetz ,gewährte“ Männern und Frauen ab dem vollendeten 20. Lebensjahr das gleiche Wahlrecht; die Bestimmung wurde sodann in die Länderwahlgesetze übernommen und in der Weimarer Reichsverfassung in Art. 22 I 1 verankert. Damit war es geschafft: Die staatsbürgerliche Gleichheit, verkörpert durch das allgemeine und gleiche Wahlrecht, war erreicht.

Am 19. Januar 1919 nahmen Frauen erstmals ihr aktives Wahlrecht als vollwertige Staatsbürgerinnen gleichberechtigt mit Männern bei nationalen Wahlen wahr; ihre Wahlbeteiligung lag bei $82,3 \%$. Zahlreiche Frauen nutzten auch das passive Wahlrecht: Von den Parteien waren ca. 310 Kandidatinnen aufgestellt worden und 37 weibliche Abgeordnete schafften schließlich den Einzug in den Reichstag. Nachrückerinnen erhöhten die Zahl auf 41. Der Frauenanteil im ersten Reichstag lag damit bei 9,7\%! Die Reichstagsabgeordnete Marie Juchaz (SPD) kommentiert in ihrer Rede am 19.2.1919 den Erfolg mit folgenden Worten: „Ich möchte hier feststellen ..., dass wir deutschen Frauen dieser Regierung nicht etwa in dem althergebrachten Sinne Dank schuldig sind. Was diese Regierung getan hat, das war eine Selbstverständlichkeit: Sie hat den Frauen gegeben, was ihnen bis dahin zu Unrecht vorenthalten worden ist."

Deutschland zählt zu Ländern, in denen Frauen ,früh` das Wahlrecht erhielten und vielfach galt es als ,Geschenk' der Revolution. Diese hat zweifellos den Prozess beschleunigt. So wurde das Frauenwahlrecht als Teil eines allgemeinen Wahlrechts zuweilen als Versuch betrachtet, die revolutionäre Situation zu beruhigen und zu kanalisieren (Rosenbusch 1998, 453f.). Aber dem voraus gegangen war ein zäher Kampf seit dem späten 18. Jahrhundert, der in die historischen und internationalen Kontexte eingebettet werden muss, um die demokratische Errungenschaft des Frauenwahlrechts vor 100 Jahren angemessen würdigen und analysieren zu können. Auch das allgemeine Männerwahlrecht war keine Selbstverständlichkeit, sondern hatte viele Einschränkungen etwa nach „Rasse“ und Klasse. Für die 
staatsbürgerliche Gleichheit von Frauen spielten zudem weitere Gründe wie etwa ihr rechtlicher Status als Geschlechtswesen eine Rolle. Einige Beispiele: Schweden hatte das Frauenwahlrecht bereits 1718 eingeführt, es 1771 wieder zurückgenommen und später zunächst nur unverheirateten Frauen gewährt. In Kanada erhielten 1883 nur Witwen das Stimmrecht. In den USA war das Wyoming Territory der Vorreiter; dort wurde 1869 das Wahlrecht eingeführt - um mehr Frauen in die neuen Siedlungsgebiete zu locken (Teele 2018).

Im Folgenden werden wir zunächst auf die Kämpfe um die staatsbürgerliche Gleichheit von Frauen seit dem späten 18. Jahrhundert verweisen. Wir wollen verdeutlichen, dass (1) diese eng mit der Frage der zivilen Gleichstellung - v.a. mit dem Recht auf Bildung - verbunden waren, (2) es sich um eine internationale Bewegung handelte und (3) es unterschiedliche Strömungen gab, die sich in ihren Forderungen (Welches Wahlrecht für wen?) und Strategien unterschieden. Im Anschluss werden wir die heutige Situation skizzieren und verdeutlichen, dass auch 100 Jahre nach Einführung des Wahlrechts de facto die politische Gleichheit von Frauen noch nicht erreicht wurde. Zwar wurden in Bezug auf die deskriptiv-quantitative Repräsentation Erfolge erzielt (d.h. in Bezug auf den numerischen Anteil von Frauen in der Politik), die aber weiterhin weit von echter Parität entfernt sind. Im Bereich substantiell-qualitativer Repräsentation (d.h. wer wessen Interessen vertritt und ob und wie diese durchgesetzt werden können) und symbolischer Repräsentation (d.h. die (in) formellen Rahmenbedingungen) bestehen aber weiterhin Mängel, die wir im letzten Teil thematisieren werden.

\section{Frühfeministisches Engagement für das Frauenwahlrecht}

Frauen waren an den politischen Freiheitskämpfen des 18. und 19. Jahrhunderts beteiligt, ohne dass daraus politische Rechte für ihr Geschlecht resultierten. Dies führte zu frühfeministischen Aktivitäten. Zwei Frauen gelten als „Mütter des Feminismus": Mary Wollstonecraft (1759-1797) argumentierte in ihrer Kampfschrift „A Vindication of the Rights of Woman“ bereits 1792, dass Frauen prinzipiell die gleichen Rechte wie Männer haben sollten; sie setzte sich insbesondere für das Recht von Frauen auf Bildung ein. Zeitgleich verfasste Olympe de Gouges (1748-1793), enttäuscht von der französischen Revolution, die ihren Gleichheits- und Freiheitsanspruch auf ,Brüderlichkeit' reduzierte, ihre „Erklärung der Rechte der Frau und Bürgerin“. Darin forderte sie scharfzüngig gleiche politische Rechte für ihr Geschlecht: „Die Frau hat das Recht, das Schafott zu besteigen. Sie muss gleichermaßen das Recht haben, die Rednerbühne zu besteigen. “2

In Deutschland wurden erste Forderungen durch die Vorreiterin Louise Otto-Peters (1819-1895) im Kontext der 1848er Revolution erhoben, die als Begründerin der bürgerlichen Frauenbewegung gilt. Die von ihr gegründete erste Frauenzeitung hatte das Motto: „Dem Reich der Freiheit werb ich Bürgerinnen“. Sie forderte bereits 1843 „die Theilnahme der weiblichen Welt am Staatsleben“ (zit.n. Ferner 2008, 7) 
und begründete sie mit dem Kongruenzprinzip der Demokratie: „Ich fordere, dass Frauen bei denjenigen Gesetzen, welche sie selbst betreffen, eine Stimme haben. Ich fordere diese Stimme für sie auch da, wo es gilt, Vertreter des ganzen Volkes zu wählen - denn wir Frauen sind ein Teil dieses Volkes.“ (zit.n. Rosenbusch 1998, 286) Die Paulskirchen-Verfassung von 1848 sah nur ein allgemeines Männerwahlrecht vor; Frauen als Staatsbürgerinnen waren nicht vorgesehen.

Allerdings sah Otto-Peters selber Grenzen der staatsbürgerlichen Rolle: „So wenig, wie eine Frau sich zur Besetzung eines Staatsamtes eignen würde, so wenig wird sie sich auch eignen, ein Schlossermeister oder Schmied zu werden.“( (ebd.) Rosenbusch schreibt dazu, dass ,auch die fortgeschrittensten Frauen dabei stehen (blieben), den Anspruch der Frauen auf Teilhabe zu postulieren, (...) zu einem öffentlichen Auftreten für politische Rechte ist es nicht gekommen“. (ebd., 287).

Da in Deutschland den Frauen die Teilnahme an politischen Veranstaltungen und die Mitgliedschaft in politischen Vereinen verwehrt war, konzentrierte sich die frühe Frauenbewegung auf die Forderung nach Bildung und Zugang zur Erwerbstätigkeit (Günther 2017). Politische Rechte wurden erst in den 1870er Jahren wieder sehr entschieden von Hedwig Dohm (1831-1919) gefordert. Sie rief ihre Geschlechtsgenossinnen 1873 dazu auf: „Fordert das Stimmrecht, denn über das Stimmrecht geht der Weg zur Selbständigkeit und Ebenbürtigkeit, zur Freiheit und zum Glück der Frau“ (zit.n. Rosenbusch 1998, 287). Angeregt u.a. von den Schriften John Stuart Mills argumentierte Dohm gleichheitstheoretisch und menschenrechtlich: „Wie die Frauen Kinder gebären, darum sollen sie keine politischen Rechte haben. Ich behaupte: weil die Männer keine Kinder gebären, darum sollen sie keine politischen Rechte haben, und ich finde die eine Behauptung mindestens ebenso tiefsinnig wie die andere.“ (zit.n: ebd., 292).

Parteien hatten sich bis dahin nicht für das Frauenstimmrecht stark gemacht. Der SPD kommt das Verdienst zu, sich als erste Partei in Deutschland - gestützt auf August Bebels Klassiker „Die Frau und der Sozialismus“ von 1879 - für ein allgemeines, geschlechterneutrales Wahlrecht einzusetzen. Für Bebel waren Frauenrechte Teil der sozialen Frage. Clara Zetkin (1857-1933) schätzte die Bedeutung des Frauenstimmrechts zunächst nicht sehr hoch ein, revidierte ihre Skepsis jedoch und wurde in der proletarischen Frauenbewegung zur stärksten Befürworterin. Sie hat die SPD in dieser Frage entscheidend beeinflusst (ebd., 306). 1891 stand die Forderung im SPD-Wahlprogramm und Bebel stellte 1895 im Reichstag erstmals einen entsprechenden Antrag, der freilich abgelehnt wurde. ${ }^{3}$ Seit den Reichstagswahlen von 1903 beteiligten sich Sozialdemokratinnen zunehmend an den Wahlkämpfen. Da dort nun auch für das Frauenstimmrecht geworben wurde, erlebte auch die Frauenstimmrechtsbewegung einen ersten Aufschwung. Es war dann die Verbindung von Frauenversammlungen mit Straßendemonstrationen, eine Idee Zetkins, welche ein wichtiges Zeichen setzte.

Auch in der sogenannten bürgerlichen Frauenbewegung kam Schwung in die Forderung nach dem Frauenwahlrecht. Das Programm des 1899 gegründeten Verbandes 
fortschrittlicher Frauenvereine enthielt u.a. das Ziel, politische Rechte für Frauen und insbesondere das Frauenstimmrecht einzuführen (ebd., 299). Der Bund deutscher Frauenvereine (BDF) verabschiedete auf Betreiben radikaler Stimmen 1902 eine Resolution zum Frauenstimmrecht und nahm die Forderung 1907 in sein Programm auf. Ihm wurde eine grundlegende Bedeutung für die Durchsetzung von Frauenforderungen zugesprochen - auch wenn viele gemäßigte Frauenrechtlerinnen das Anliegen noch für verfrüht hielten. Radikale Frühfeministinnen gründeten erste Frauenstimmrechtsvereine. Der Verein für Frauenstimmrecht wurde 1902 von Lida Gustava Heymann und Anita Augspurg mit dem Ziel gegründet, für das Stimmrecht durch Agitationsreisen, Pressekampagnen, Petitionen und Lobbying zu mobilisieren. Zugleich sollten Frauen durch politische Bildung für das Wahlrecht fit gemacht werden. Die Aktivitäten in Deutschland waren nicht isoliert, sondern die Frauenrechtsaktivistinnen waren international gut vernetzt. Sie standen in regem Austausch, es gab Vortragsreisen und in den Verbandszeitschriften der Frauenbewegungen wurde über die Aktivitäten zum Stimmrecht in anderen Ländern berichtet (Günther 2017). Besonders aktiv waren die so genannten Suffragetten-Bewegungen in Großbritannien und in den USA. „Deeds not words“ (Taten statt Worte) war das Motto der britischen Suffragetten, von denen sich nach 1911 ein Teil radikalisierte und - anders als die Bewegung in den meisten Ländern - schließlich auch zu militanten Aktionen wie Sachbeschädigung griff (Günther 2006; 2017). Mildere Formen der Aktivitäten der britischen Suffragetten, z.B. Straßendemonstrationen, hingegen übernahm der Verein für Frauenstimmrecht (Günther 2006, 301; Günther 2017). 1904 fand die Gründungskonferenz des Weltbundes für Frauenstimmrecht in Berlin statt.

\section{Der Weg zur Verabschiedung des Frauenstimmrechts}

In Deutschland waren ab 1902 die Liberalisierungen und ab 1908 die Aufhebung des Reichsvereinsgesetzes, das zuvor die politischen Aktivitäten von Frauen stark einschränkte, wichtige Schritte; die Stimmrechtsorganisationen fanden regen $\mathrm{Zu}$ lauf. ${ }^{4} 1911$ wurde in Deutschland erstmals der Internationale Frauentag gefeiert, der vielerorts und auch in den Folgejahren zu Versammlungen und Demonstrationen zugunsten des Frauenwahlrechts führte. Parallel dazu gab es - erfolglose - Versuche, das Frauenstimmrecht quasi durch die Hintertür einzuführen, nämlich durch eine Interpretation der bestehenden Wahlgesetze, demzufolge die Verwendung des männlichen Geschlechts in der Formulierung des Wahlgesetzes eigentlich geschlechtsneutral gemeint sei und somit auch Frauen einschließe (Rosenbusch 1998, 364). Letztlich blieb nur der Weg über ein Gesetz. Eine Frauenpetition für ein solches Gesetz wurde 1914 in einer der letzten Reichstagsdebatten diskutiert. Bemerkenswert sind die Argumente gegen das Wahlrecht: (1) Dies sei nicht im Staatsinteresse, da das Frauenstimmrecht das Gewicht der anderen Stimmen reduziere; (2) den Frauen fehlten die bildungsmäßigen Voraussetzungen; (3) das Stimmrecht wirke familienzerstörend, weil Frauen ihre Mutterpflichten vernachlässigen könnten oder es Streit 
zwischen Eheleuten über Politik geben könnte (Eulers 1991, 26f.) Mit dem Ausbruch des 1 . Weltkrieges kamen politische Reformen dann nahezu zum Erliegen - Vorrang hatte das nationale Interesse; zudem wurden Aktivitäten durch Versammlungsverbote und Pressezensur unterbunden. Auch der für 1915 bereits in Berlin geplante Internationale Kongress für Frauenstimmrecht wurde abgesagt.

1917 wurden die Wahlrechtsdebatten wiederaufgenommen und eine Verfassungskommission legte hierzu einen Bericht vor: das Frauenstimmrecht fand Berücksichtigung. Teile der bürgerlichen und sozialdemokratischen Frauenbewegung begannen in Bezug auf die Stimmrechtsforderung zusammenzuarbeiten; sie begründeten ihre Forderung mit dem wichtigen Kriegsbeitrag der Frauen, mit ihrer gestiegenen Erwerbstätigkeit und ihrem Dienst für das Vaterland. Die bürgerlichen Parteien nahmen immer noch eine abwartende bis ablehnende Haltung ein; die Zustimmung der Zentrums- und der Nationalliberalen Partei zu einem SPD-Initiativantrag pro Frauenstimmrecht kam 1918 erst in letzter Minute zustande - als Zugeständnis, um die revolutionäre Lage zu beruhigen (Rosenbusch 1998, 453f.).

Somit wurde die Forderung nach dem Frauenstimmrecht sowohl von der bürgerlichkonservativen als auch von der radikalfeministischen und der proletarischen Frauenbewegung vertreten. Alle drei Strömungen kritisierten, bei allen Differenzen über die Art des Frauenwahlrechts und über die angemessene Strategie, den männlichen Alleinvertretungsanspruch in der Politik; ein Aspekt, der auch heute noch relevant ist, wie der Beitrag von Anne Cress in diesem Heft zeigt.

\section{Und wo bleibt die Gleichheit?}

Was hat sich seit der Einführung des Frauenwahlrechts vor 100 Jahren getan? Heute wählen zwar noch immer mehr Männer als Frauen; der Unterschied ist aber seit Jahrzehnten deutlich gesunken und betrug bei der letzten Wahl lediglich 0,3 Prozentpunkte (Der Bundeswahlleiter 2017b). Neben der Beteiligung an Wahlen stand jedoch nicht minder die Beteiligung in der Politik im Vordergrund der Forderungen der frühen Frauenbewegungen. Bis jedoch ein nennenswerter Anteil von Frauen in die Parlamente einzog, verging viel Zeit. In der Literatur wird häufig argumentiert, dass es einen Zusammenhang zwischen dem (Anstieg des) Anteil(s) von Frauen und politischen Inhalten oder politischen Stil gebe. Erst eine „kritische Masse“ von mindestens 30\% Frauen in Parlamenten könne politischen Einfluss ausüben. Auch wenn die konkrete Zahl sowie der Zusammenhang zwischen deskriptiver und substantieller Repräsentation umstritten ist (Childs/Krook 2008), hat sich die Zahl dennoch als Richtwert für internationale Vergleiche wie auch für (partei)politische Strategien zur Erhöhung des Frauenanteils entwickelt. Zugleich können aber auch durch „kritische Akte“ und durch Einzelpersonen Verbesserungen im Sinne substantieller Repräsentation erzielt werden (vgl. Mushaben in diesem Heft).

Im Folgenden werden Entwicklungen in der deskriptiven Repräsentation von Frauen auf unterschiedlichen Ebenen - international, national, regional - dargestellt. 
Neben Deutschland gab es auch in anderen Ländern Frauenstimmrechtsbewegungen, die teilweise erfolgreicher als in Deutschland waren und in denen das Stimmrecht früher eingeführt wurde (Paxton/Hughes 2017), so v.a. in den skandinavischen Ländern. Finnland führte 1906 zeitgleich das allgemeine Wahlrecht für Frauen und Männer ein; Norwegen gewährte den Frauen 1907 zunächst das passive(!) und ab 1913 auch das aktive Wahlrecht; Dänemark und Island folgten 1915. In anderen europäischen Ländern wurde das Stimmrecht etwa zeitgleich eingeführt, so etwa 1918 in Österreich, Polen und Luxemburg, 1919 in den Niederlanden, 1921 in Schweden und 1918 bzw. 1928 in Großbritannien ${ }^{5}$ (die USA folgten 1920). Nach dem zweiten Weltkrieg führten weitere europäische Länder das Frauenwahlrecht ein: Frankreich 1944, Slowenien und Bulgarien 1945, Italien 1946 und Griechenland 1952. Nachzügler waren 1971 die Schweiz und 1984 (!) Liechtenstein. ${ }^{6}$

Der großen Heterogenität der Einführung des Frauenwahlrechts entsprechend gibt es auch heute noch große Unterschiede bei den Frauenanteilen in den nationalen Parlamenten (vgl. Abbildung 1). Aufgrund der großen Variation zwischen den Ländern und innerhalb der Gruppen, die in der gleichen Phase das Wahlrecht eingeführt haben, lässt sich - wie in der Forschung teils vermutet - aber nicht schlussfolgern, dass Länder, in denen Frauen früh das Wahlrecht erhielten, heute höhere Frauenanteile in den Parlamenten aufweisen. So haben Nachzügler wie Portugal, die Schweiz oder Belgien heute ähnlich hohe Anteile wie die Vorreiter Österreich oder Deutschland, während einige osteuropäische Länder trotz früher Verabschiedung des Frauenstimmrechts heute noch geringe Anteile aufweisen.

Abbildung 1: Frauen in nationalen Parlamenten, 2018 (in \%)

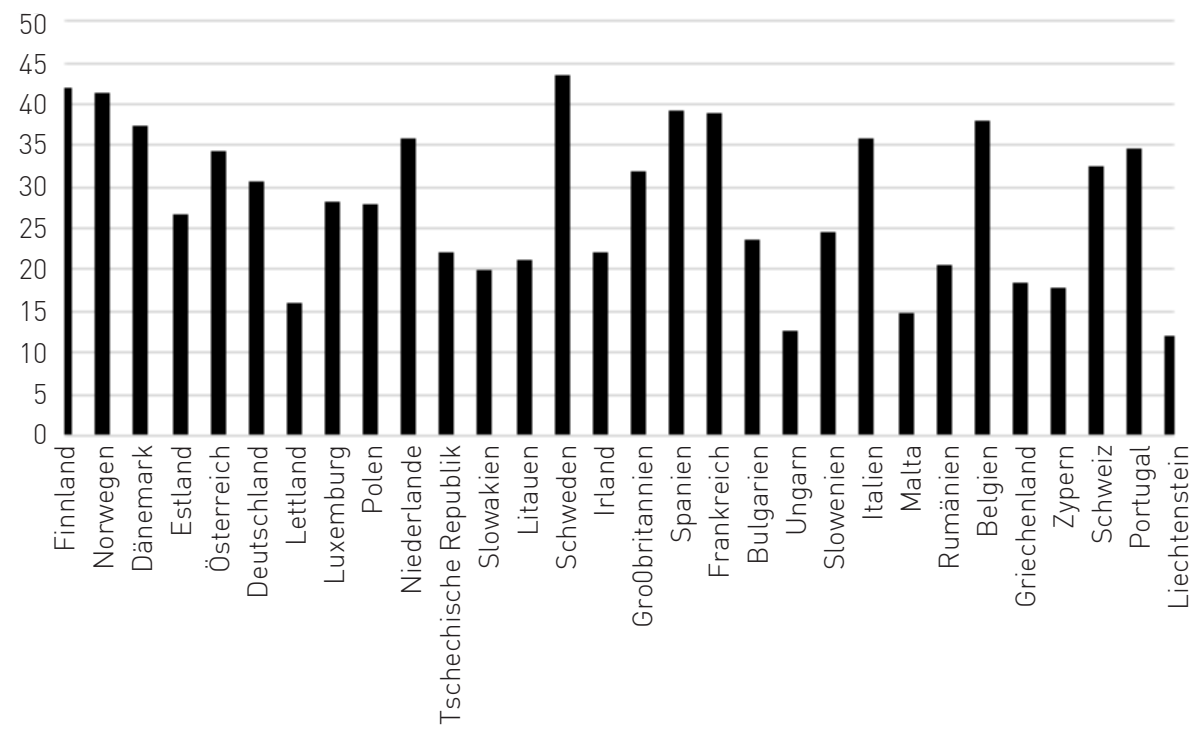

Quelle: Inter-Parliamentary Union; Paxton/Hughes 2016. 
Bemerkenswerterweise haben aber, selbst unter den Nachzüglern, insgesamt 21 EU-Mitgliedstaaten einen höheren Frauenanteil unter den Europaabgeordneten vorzuweisen als in den nationalen Parlamenten; dies betrifft etwa auch Deutschland (37\%) oder auch Rumänien, Frankreich, Großbritannien - und selbst den europäischen Spitzenreiter Finnland (Europäisches Parlament 2018, 6). Insgesamt liegt der Frauenanteil im Europäischen Parlament derzeit bei 36,1\% (ebd., 5).

In Deutschland sind wir auch 100 Jahre nach der Einführung des Wahlrechts noch weit von Parität entfernt, wobei sich die Anteile in der DDR-Volkskammer und dem Deutschen Bundestag von Anfang an unterschiedlich entwickelten. Während in der Volkskammer der Frauenanteil von Beginn an über 20\% lag und bis 1986 auf 32,2\% anstieg (Pawlowski 2008), wurde im Bundestag die „kritische Masse“ von 30\% erst 1998, also deutlich nach der Wiedervereinigung, erreicht (vgl. Abbildung 2). Für eine Steigerung des Frauenanteils spielen die nach und nach eingeführten parteiinternen Quotenregelungen für Wahllisten eine zentrale Rolle (vgl. Tabelle 1 im nächsten Abschnitt). Mit 36,5\% war der Frauenanteil während der 18. Legislaturperiode (2013-2017) am höchsten, sank aber mit der letzten Wahl 2017 auf 31\% - eine Folge des Rechtsrucks im Deutschen Bundestag.

Abbildung 2: Frauenanteil im Deutschen Bundestag, 1949-2017

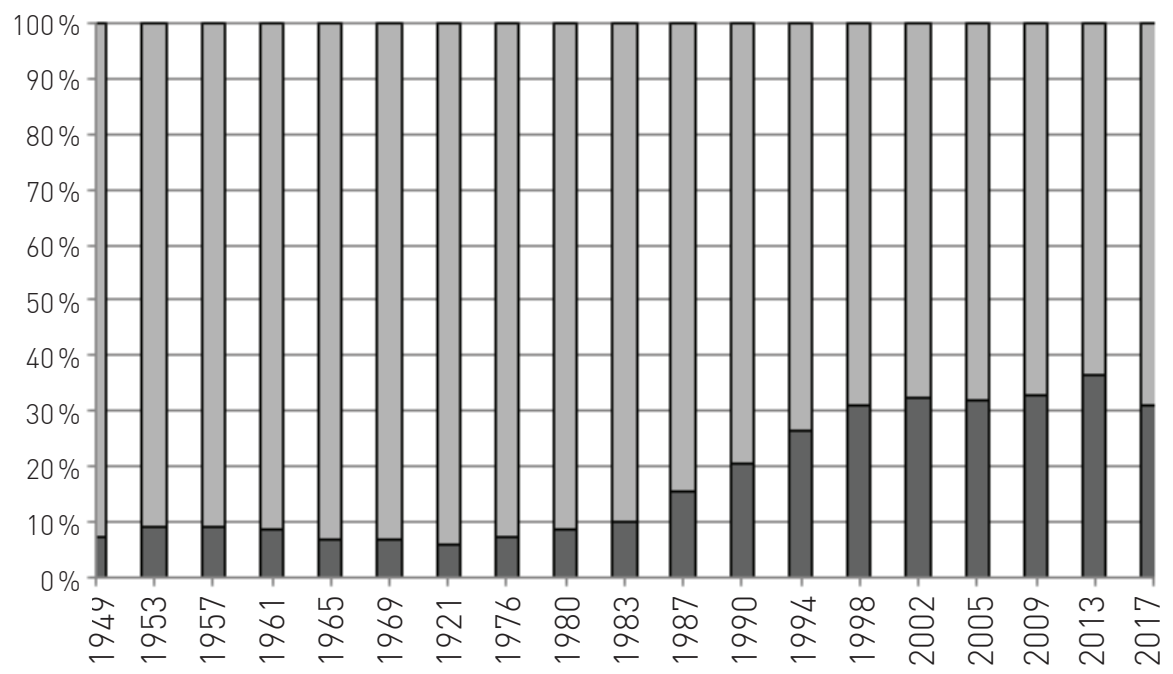

Quelle: Bundeswahlleiter 2017a; Daten für 2017 von bundestag.de (2018).

Ein Erklärungsfaktor für die niedrigen weiblichen Abgeordnetenanteile ist der Frauenanteil an den Parteimitgliedern. Wie Louise Davidson-Schmich in diesem Heft zeigt, stellen die Parteien zwar teilweise durchaus Kandidatinnen gemäß dem Anteil ihrer Mitglieder auf-aber der liegt für alle Parteien unter 50\%. Die AfD hat lediglich 
16\% weibliche Parteimitglieder, die CSU ein Fünftel, die FDP 23\%, die CDU ein Viertel, die SPD ein knappes Drittel. In der Linken und den Grünen stellen sie 37\% bzw. 39\% (Niedermayer 2017). Diejenigen Parteien, die einen höheren weiblichen Mitgliederanteil haben (Grüne, Linke und SPD), haben sogar einen deutlich höheren Frauenanteil bei den Abgeordneten als bei den Parteimitgliedern. CDU/CSU und die AfD hingegen haben anteilig weniger Frauen im Parlament als weibliche Parteimitglieder (vgl. Abbildung 3). Nur bei der FDP entspricht der (niedrige) Frauenanteil bei den Parteimitgliedern dem der Abgeordneten. ${ }^{7}$

Abbildung 3: Frauenanteile unter den Abgeordneten des 19. Bundestages nach Partei, 2018

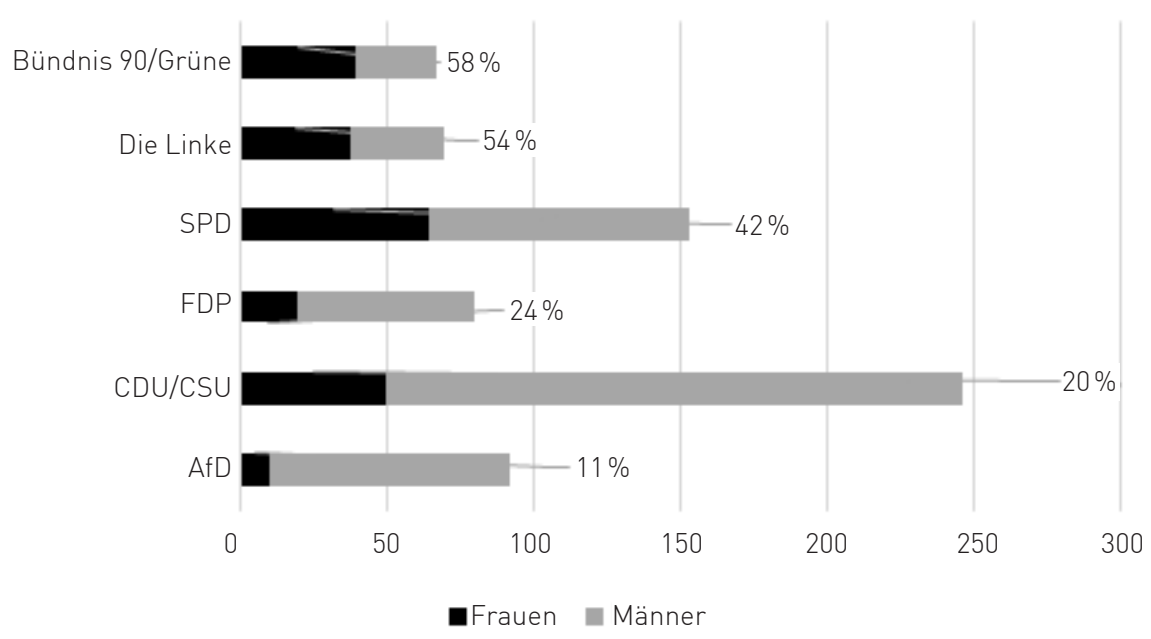

Quelle: Deutscher Bundestag 2018 (Zugriff 3.7.2018)

Eine ähnlich große Heterogenität wie im internationalen Vergleich lässt sich auch in den deutschen Landesparlamenten finden (vgl. Abbildung 4). 2018 variieren die Anteile zwischen 24\% in Sachsen-Anhalt und 41\% in Brandenburg, wobei keineswegs ein kontinuierlicher Anstieg, sondern in neun von 16 Ländern sogar ein Rückgang des Frauenanteils zwischen 2004 und 2018 zu verzeichnen ist. Dieser hängt in einigen Fällen von neuen parteipolitischen Konstellationen in den Landtagen ab (u.a. Einzug der AfD), jedoch gibt es kein generelles Muster, das die Entwicklungen erklärt (Kroeber et al. 2018). Sowohl Uta Kletzing als auch Louise Davidson-Schmich zeigen in diesem Heft die Schwierigkeiten und die Bedingungen für Frauen auf, auf lokaler Ebene Kandidatinnen für politische Ämter zu werden. 


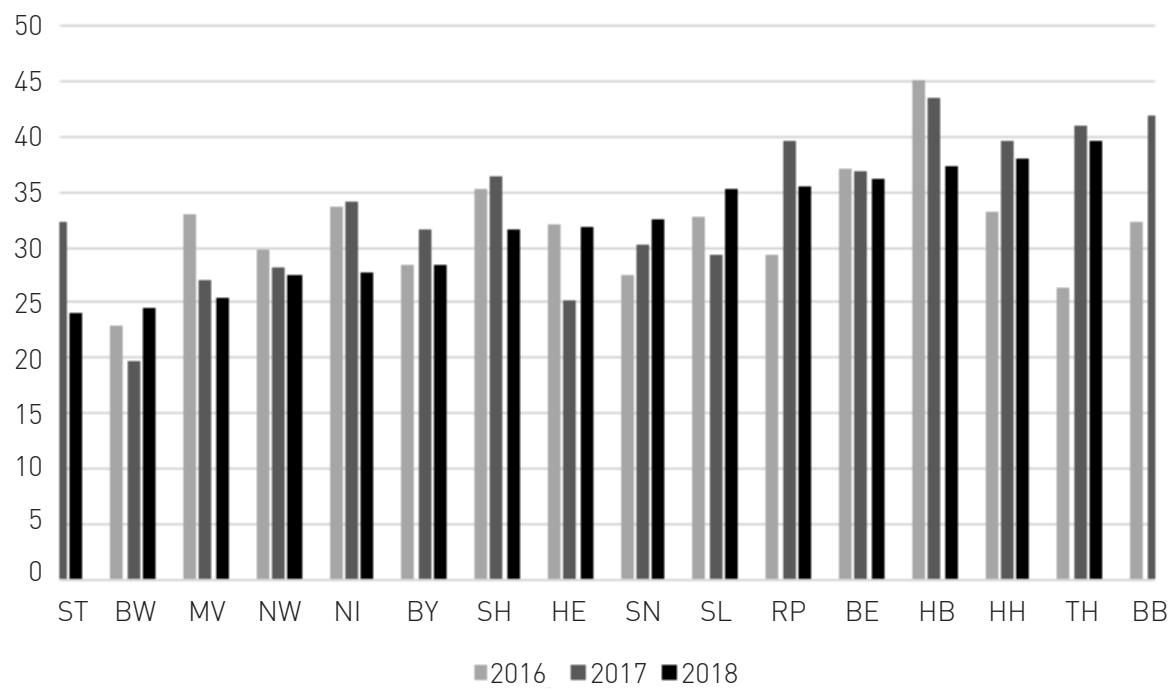

Anmerkung: $\mathrm{BW}=$ Baden-Württemberg, $\mathrm{BY}=$ Bayern, $\mathrm{BE}=\mathrm{Berlin}, \mathrm{BB}=$ Brandenburg, $\mathrm{HB}=$ Bremen, $\mathrm{HH}=$ Hamburg, $\mathrm{HE}=$ Hessen, $\mathrm{MV}=$ Mecklenburg-Vorpommern, $\mathrm{NI}=$ Niedersachsen, NW=NordrheinWestfalen, RP=Rheinland-Pfalz, SL=Saarland, SN=Sachsen, ST=Sachsen-Anhalt, SH=SchleswigHolstein, TH=Thüringen.

Quelle: European Institute for Gender Equality (EIGE) Gender Statistics Database, Zugriff 1.7.2018

Der Überblick über den Stand und die Entwicklungen der politischen Repräsentation von Frauen verdeutlicht, dass weder auf der Ebene des Bundes noch auf der Ebene der Länder (kontinuierlich) mehr als ein Drittel der Abgeordneten weiblich sind. Dieses Muster setzt sich auch auf der Kommunalebene fort, wo, wie Uta Kletzing in ihrem Beitrag für dieses Heft schreibt, derzeit sogar nur 25\% Mandatsträgerinnen und nur 10\% (Ober-)Bürgermeisterinnen und Landrätinnen sind. Kroeber et al. (2018) sprechen aufgrund der diskontinuierlichen Entwicklung auch von einem Sättigungspunkt, der in Deutschland deutlich vor der Geschlechterparität erreicht ist und von international vergleichenden Studien bestätigt wird, wonach der Anteil von Frauen selten 30\% übersteigt (Paxton/Hughes 2017). Schweden und Finnland sind eher Ausnahmen.

\section{Repräsentation - aber welche?}

Auf Basis der gerade skizzierten unerreichten Parität wollen wir ausleuchten, wie sich Repräsentationsfragen weiterdenken lassen und welche Dimensionen dabei eine Rolle spielen. Wir knüpfen dabei an den Klassiker The Concept of Representation von Hanna Pitkin (1967) an und befassen uns - angesichts formal gewährleisteter Repräsentation - damit, wie sich deskriptive, substanzielle und symbolische Repräsentation herstellen lassen bzw. worin die Herausforderungen bestehen. 


\section{Deskriptive Repräsentation}

In den Parlamenten und Regierungen dieser Welt sind Frauen - und auch andere marginalisierte Gruppen (z.B. Musliminnen im Bundestag, vgl. Jenichen in diesem Heft) - nach wie vor unterrepräsentiert - mit sehr wenigen Ausnahmen. Und das, obwohl weltweit seit Jahrzehnten verschiedene Instrumente genutzt werden, unter anderem verschiedenste Quotenarten: gesetzlich festgelegte Quoten (z.B. Argentinien, Frankreich), Parteiquoten (z.B. Österreich, Südafrika) und reservierte Mandate (z.B. Marokko, Uganda). ${ }^{8}$ In Deutschland sind (freiwillige) Parteiquoten das vorherrschende Instrument, wenngleich die Parteien diese sehr unterschiedlich ausgestalten (vgl. Tabelle 1).

Tabelle 1: Quotenregelungen in den deutschen Parteien

\begin{tabular}{|l|l|l|l|}
\hline Partei & $\begin{array}{l}\text { Jahr der } \\
\text { Einführung }\end{array}$ & Regelung & $\begin{array}{l}\text { Aktueller Frauenanteil } \\
\text { im Bundestag (\%) }\end{array}$ \\
\hline Bündnis90/ Grüne & 1986 & $\begin{array}{l}50 \% \text {-Geschlechterquote für } \\
\text { Liste, ungerade Sitze für } \\
\text { Frauen, gerade Sitze offen für } \\
\text { Männer und Frauen }\end{array}$ & 58,0 \\
\hline SPD & 1988 & $\begin{array}{l}\text { zuerst 30\%, seit 1998 40\% } \\
\text { Geschlechterquote für Liste }\end{array}$ & 42,0 \\
\hline Die Linke & 1990 & $\begin{array}{l}50 \% \text {-Geschlechterquote für } \\
\text { Liste }\end{array}$ & 54,0 \\
\hline CDU & 1996 & 30\% Frauenquorum & 20,0 \\
\hline CSU & -- & $\begin{array}{l}\text { Keine Regelung (40\% für } \\
\text { Parteifunktionen) }\end{array}$ & 22,5 \\
\hline FDP & -- & Keine Regelung & 10,6 \\
\hline AfD & -- & Keine Regelung & \\
\hline
\end{tabular}

Quelle: eigene Zusammenstellung.

Quoten sind ein weitverbreitetes Instrument und die etablierten Demokratien stehen nicht unbedingt an der Spitze. Quoten bringen sehr unterschiedliche Resultate: In manchen Ländern sind Quotenvorgabe und der Anteil der Frauen im Parlament annähernd gleich, bei manchen liegt der Frauenanteil höher, bei anderen niedriger. Deutschland ist unter den Ländern, in denen Parteiquoten verabschiedet wurden, hinsichtlich des Frauenanteils im Parlament nicht unter den ersten zwanzig und insgesamt aktuell nur auf Platz 46. ${ }^{9}$ Angesichts dieser ernüchternden Ergebnisse diskutiert Cara Röhner in ihrem Beitrag zu diesem Heft, wie aus verfassungswissenschaftlicher Sicht eine gesetzliche geschlechtergerechte Nominierung für alle staatlichen (nicht nur die legislativen) Ämter der Parteien begründet werden könnte. 
Angesichts der begrenzten Erfolge stellt sich die Frage nach Alternativen. Rainbow Murray (2014) schlägt vor, statt Frauenquoten Maximalquoten von z.B. 70\% für Männer festzulegen, damit deren permanente Überrepräsentation sichtbarer wird und sich die Wahrnehmung ändert. Denkbar sind auch interne Parteiregeln wie „Twinning“ bei Direktmandaten, bei denen Kanditat*innen gleiche Anteile an Kandidaturen in „sicheren“ und „umkämpften“ Bezirken erhalten. Bisher werden Frauen, wenn sie denn überhaupt als Direktkandidatin aufgestellt werden, häufig immer noch in umkämpften, um nicht zu sagen aussichtslosen Bezirken platziert (Davidson-Schmich/Kürschner 2011). Ähnlich funktionieren Doppellisten, bei denen Wahlbezirke zusammengelegt würden und es für die zwei zu vergebenen Mandate jeweils eine Frauen- und eine Männerliste gäbe - Frankreichs Parité-Gesetz hat eine vergleichbare Systematik (Murray 2012). In manchen Ländern werden Sonderfonds (durch Zivilgesellschaft, Parteien, Staat) für Kandidatinnen oder für gleichstellungsorientierte Kandidat*innen eingerichtet, mit denen Kampagnen, Kinderbetreuung, und persönliche Sicherheit (Stichwort Bedrohungen, sexuelle Belästigung u.ä.) finanziert werden können (Krook/Norris 2014).

Wie auch der Beitrag von Christina Fiig zu gleichberechtigter Repräsentation in den parlamentarischen Ausschüssen in dieser Ausgabe verdeutlicht, sind zudem Quoten für Parlamentsfunktionen und die öffentliche Verwaltung (Führungspositionen, Anteil innerhalb von Ausschüssen angelehnt an Parlamentsanteilen) erforderlich. ${ }^{10}$ Auch in dieser Hinsicht ist das Europäische Parlament recht fortschrittlich. So sind 5 der 14 Vizepräsident*innen und 50\% der Ausschussvorsitzenden weiblich (Europäisches Parlament 2018). In den Ausschüssen selber schwankt der Frauenanteil allerdings zwischen 16,5\% im Haushaltskontrollausschuss und 78,4\% im Ausschuss für die Rechte der Frau und Gleichstellung der Geschlechter (ebd.).

Auch parteiübergreifende Organisationen innerhalb des Parlaments, so genannte „Women's Caucus“ (Frauenarbeitskreise), haben nachhaltig zu steigender deskriptiver Repräsentation beigetragen. Damit wird zumindest, so die Annahme, eine positive Voraussetzung auch für substantielle Repräsentation geschaffen. Gleichwohl sollte, um zukunftsweisend und angemessen zu sein, deskriptive Repräsentation nicht simpel entlang von Geschlechterbinarität gedacht werden. Weitere sich überlagernde und gegenseitig formende Strukturkategorien wie beispielsweise Ethnie, soziale Klasse, Alter, sexuelle Orientierung, u.ä. prägen in unterschiedlichster Weise die Chance, Repräsentationsfunktionen in der Politik wahrzunehmen, wie in dieser Ausgabe die Beiträge von Davidson-Schmich und Jenichen zeigen.

\section{Substanzielle Repräsentation}

Während sich deskriptive Repräsentation relativ einfach erfassen lässt, fällt das für substanzielle Repräsentation schwerer. Wer vertritt wessen Interessen? Wer sollte wessen Interessen vertreten? Welche Interessen werden nicht vertreten? Wie kann 
mit intersektionalen Aspekten umgegangen werden? Diese Fragen sind nicht ohne weiteres ,messbar“.

Häufig wird ein direkter Zusammenhang zwischen deskriptiver und substanzieller Repräsentation unterstellt, wenn beispielsweise über „kritische Masse“ oder „kritische Akteur*innen“ diskutiert wird, wobei die Ergebnisse in verschiedene Richtungen weisen (Childs/Krook 2009; Franceschet/Krook/Piscopo 2012). Sacchet (2008) hat wiederum gezeigt, dass Quoten dazu beitragen, Gleichstellungsthemen auf die politische Agenda zu bringen und das Bewusstsein dafür insgesamt zu erhöhen. Blome und Fuchs (2017) reflektieren, inwieweit sich substantielle Repräsentation von Frauen in Macht verwandelt, also ob der Einsatz von Frauen für Frauen entsprechende Policy-Outputs hervorbringt. Für den Deutschen Bundestag stellte Xydias (2014) hierzu fest, dass Quoten zu mehr Beteiligung an gleichstellungspolitischen Debatten führten - allerdings nur bei Männern, nicht bei Frauen. Xydias führt das darauf zurück, dass Quoten eher Männer sozialisieren, da Frauen das Thema ohnehin mehr bewusst sei. Gleichzeitig verneinte sie für Deutschland, dass steigende deskriptive auch zu mehr substanzieller Repräsentation führe. Diesen Aspekt untersuchen Celis und Childs (2012) sowie Celis und Erzeel (2015) in ihrer Auseinandersetzung mit konservativen Politiker*innen ebenfalls kritisch; Mushaben (in diesem Heft) verweist hingegen darauf, dass auch Einzelakteurinnen - wenn sie in entsprechender Machtposition wie die Bundeskanzlerin sind - einflussreich sein können.

Unabhängig davon stehen in der Europäischen Union und Deutschland bereits konkrete, wenn auch bisher nicht konsequent umgesetzte Instrumente für substanzielle Repräsentation, zur Verfügung: Gender Mainstreaming (GM), Gender Budgeting (GB) und die gleichstellungsorientierte Gesetzesfolgenabschätzung. GM wird auf den verschiedenen politischen Ebenen (EU(-Mitgliedsstaaten), Bund, Land, Kommunen, Organisationen) unterschiedlich umgesetzt. ${ }^{11} \S 2$ der Gemeinsamen Geschäftsordnung (GGO) der Bundesministerien benennt die Gleichstellung von Männern und Frauen als „durchgängiges Leitprinzip“, das „bei allen politischen, normgebenden und verwaltenden Maßnahmen“" umzusetzen ist (Bundesministerium des Innern 2011). Während GM und auch GB zu Beginn der 2000er Jahre in vielen Ländern neue, oft ausprobierte und gleichzeitig aus der feministischen Wissenschaft kritisch beäugte politische Strategien waren (Ahrens/Scheele/Van der Vleuten 2016), werden sie aktuell aus dem rechtsgerichteten Spektrum diskreditiert und angegriffen (Schmincke 2018; Kuhar/Paternotte 2017).

Ein zunehmend zentraler Bereich für substanzielle Repräsentation sind zudem Gesetze gegen geschlechtsspezifische Gewalt und sexuelle Belästigung, da mit diesen (un)sichtbare Machtverhältnisse und Ausschlussmechanismen bearbeitet werden.

\section{Symbolische Repräsentation}

Neben quantitativer und inhaltlicher spielt symbolische Repräsentation eine bisher wenig erforschte Rolle (Lombardo/Meier 2014), d.h. wie Repräsentation jenseits 
von Wahlfragen und dem politischen Kerngeschäft aussehen kann (Saward 2009) und wie hier „gendersensible Parlamente“ zu fassen sind (Childs 2015; Galligan/ Meier 2015; Wängnerud 2009). Wer wird (wie) dargestellt (Bilder, Räume, Sprache, Veröffentlichungen)? Welche Regeln bestehen (Vorschriften und Sanktionen sexueller Belästigung und sexistischer Äußerungen, Regelungen zu Schwangerschaft, Elternzeit)? Welche Gepflogenheiten gibt es (Zeremonien, Rituale, Uhrzeiten von Abstimmungen, u.ä.)? Wo liegen „Schmerzgrenzen“ (Diskussionsstile, Sexismus, u.ä.)? Eine interessante Illustration für den Gender-Charakter von Parlamenten ist etwa, dass jüngst die Abgeordnete Henfling mit ihrem (schlafenden) Baby vom Landtagspräsidenten aus dem Thüringer Plenarsaal verwiesen wurde. Er riet ihr, dass Baby betreuen zu lassen; allerdings gibt es im Thüringer Landtag keine Betreuungsoption. Mehr noch: Für Abgeordnete gelten die gesetzlichen Elternzeitregelungen nicht (nur der Mutterschutz ist obligatorisch), da ihr Mandat mit verfassungsrechtlichen Pflichten nach Art. 38 GG verbunden ist. Somit stellt sich die Frage nach der Vereinbarkeit von Familie und Mandat. Einzelne Parlamente, so etwa der Landtag von Brandenburg oder der von Baden-Württemberg, haben hierzu Regelungen getroffen, die eine Vereinbarkeit erleichtern (vgl. Fokken 2018).

Symbolische Repräsentation befasst sich auch damit, wie sich ein höherer Frauenanteil in der Politik auf die öffentliche Wahrnehmung von Politikerinnen und das Stereotyp „Politik ist Männersache“ auswirkt (High-Pippert/Comer 1998). Ein weiterer Forschungsschwerpunkt liegt auf der Frage, ob politische Institutionen als legitimer wahrgenommen werden, wenn mehr Frauen vertreten sind (Childs 2004, Schwindt-Bayer/Mishler 2005). Auch hier sind die Ergebnisse insbesondere zu den Auswirkungen von Quoten widersprüchlich: In einigen Ländern ergab sich durch Quoten insgesamt ein kultureller und sozialer Wandel, in anderen lösten sie Widerstand gegenüber Politiker*innen und Gleichberechtigung aus (Franceschet/Krook/ Piscopo 2012).

\section{Fazit}

Für ihr Stimmrecht mussten Frauen lange kämpfen. Was heute selbstverständlich klingt - das Ziel der staatsbürgerlichen Gleichstellung mit den Männern - war damals jedoch nicht unumstritten und keinesfalls „im Interesse aller Frauen“. Schon damals zeigten sich mit dem Geschlecht überlagernde Interessen, die teilweise in den unterschiedlichen Strömungen der Frauenbewegung Ausdruck fanden. Auch heute ist sich die Forschung uneins darüber, ob von genuinen „Fraueninteressen“ gesprochen werden könne oder nicht vielmehr eine intersektionale Perspektive besser in der Lage sei, vorhandene Unterschiede unter Frauen (und unter Männern) und damit die Realität abzubilden.

Rückblickend zeigt sich jedoch auch, wie wirksam ein gemeinsames Eintreten für das Frauenwahlrecht war. Trotz Differenzen über Ziele und Strategien verfolgten alle Strömungen der Frauenbewegung das Ziel, dem männlichen Alleinvertretungs- 
anspruch in der Politik die verstärkte politische Teilhabe von Frauen entgegenzusetzen. Unterstützt wurden sie von linken Parteien wie der SPD, die sich auch heute noch durch eine bessere Repräsentation von Frauen als konservative und rechte Parteien auszeichnen.

Von Gleichheit im politischen Amt war und ist dennoch nicht zu reden. In Deutschland dauerte es lange Zeit, bis ein nennenswerter Anteil von Frauen im Bundestag vertreten war, und er liegt seit nunmehr zwanzig Jahren relativ stabil bei etwa 30\% - Tendenz derzeit eher fallend. Obwohl sich die genderorientierte vergleichende Repräsentationsforschung seit vielen Jahren intensiv mit den Trends und Gründen für die weiterhin bestehende Unterrepräsentation von Frauen in Parlamenten und Regierungen auseinandersetzt, besteht nach wie vor Forschungsbedarf zur Erklärung der Entwicklungen und Bewertung des Einflusses von Frauen in der Politik.

Diese und weitere Aspekte werden in den Beiträgen dieses Schwerpunkts behandelt. So sind laut Anne Cress viele Fragen, die zur Zeit der Kämpfe um das Frauenwahlrecht relevant waren, auch heute noch aktuell. Auch bei den rechtlichen Bedingungen, mit denen Repräsentation im Sinne von Geschlechterparität abgesichert werden könne, gibt es nach Cara Röhner genügend Ansatzpunkte. Bei der Frage, wie sich der Anteil von weiblichen Abgeordneten erhöhen ließe, geht es laut Louise Davidson-Schmich nicht um „fixing women“, sondern darum, informelle Institutionen die eine gleichberechtigte Teilhabe unterminieren, zu verändern. In ähnlicher Weise verweist Anne Jenichen auf noch unzureichende Bemühungen der Parteien bei der politischen Repräsentation muslimischer Frauen in Deutschland, bei denen zudem Religion als Differenzkategorie quer zu Migrationshintergrund liegt. Joyce Marie Mushaben betrachtet in ihrem Beitrag Deutschlands erste Bundeskanzlerin, Angela Merkel und argumentiert, dass diese trotz ihrer CDU-Mitgliedschaft und ihrer wiederholten Beteuerung, keine Feministin zu sein, mehr für die Geschlechtergleichheit in Deutschland getan hat als alle ihre Amtsvorgänger. Dass auch nach 100 Jahren passivem Frauenwahlrecht Männer und (hegemoniale) Männlichkeit den politischen Raum dominieren, zeigt Uta Kletzing am Beispiel von hauptamtlichen Bürgermeisterinnen in Nordrhein-Westfalen, während Christina Fiig schließlich am Beispiel Dänemark und den parlamentarischen Ausschüssen zeigt, dass sich die ungleiche Repräsentation in diesen sowohl horizontal als auch vertikal fortsetzt.

Für die Zukunft besteht die zentrale Herausforderung - in der Forschung ebenso wie in der politischen Praxis - darin, zum einen die Zusammenhänge zwischen den Repräsentationsdimensionen zusammenzudenken und Interdependenzen in den Blick zu nehmen und zum anderen eine intersektionale Perspektive hierbei konsequent einzubeziehen.

\section{Anmerkungen}

1 Teile dieses Beitrags sind aus Abels (2011) entnommen.

2 Zumindest das Recht auf das Schafott wurde ihr ..gewährt”, denn sie wurde 1793 von den Revolutionären hingerichtet. Als Begründung führten die Richter an: „Ein Staatsmann wollte 
sie sein, und das Gesetz hat die Verschwörerin dafür bestraft, dass sie die Tugenden vergaß, die ihrem Geschlecht geziemen." (Zit.n. Lang 2004, 66)

3 Die SPD brachte danach mehrere Resolutionen zugunsten des Frauenwahlrechts in den Reichstag ein. Erst ab 1908 fand die Forderung auch bei anderen Reichstagsparteien langsam Zuspruch.

4 Bis zum Jahr 1914 zählten sie ca. 14.000 Mitglieder (Rosenbusch1998, 301).

51918 erhielten nur Frauen ab dem 30. Lebensjahr - unter bestimmten Voraussetzungen - das Wahlrecht; das allgemeine gleiche Wahlrecht wurde erst 1928 eingeführt.

$6 \mathrm{Vgl}$. https://www.bundestag.de/besuche/ausstellungen/parl_hist/frauenwahlrecht/einfuehrung/246998 (Abfrage: 2.6.2018)

7 Dieses Links-Rechts-Muster in Bezug auf Frauenanteile findet sich auch im Europäischen Parlament $(2018,10)$ wieder.

8 Für eine detaillierte Übersicht vgl. Franceschet, Krook und Piscopo (2012), Hughes, Paxton und Krook (2017), sowie zu aktuellen Daten www.idea.int/data-tools/data/gender-quotas und die Inter-Parliamentary Union, www.ipu.org, (8.6.2018).

9 Vgl. http://archive.ipu.org/wmn-e/classif.htm (31.7.2018).

10 Auch die aktuelle Diskussion um die Besetzung zentraler Funktionen in den Bundesministerien zeigt die Notwendigkeit eindrücklich. Vgl. https://faktenfinder.tagesschau.de/inland/ frauen-ministerien-101.html (8.6.2018).

11 Vgl. ausführlicher die Übersicht des Europäischen Gleichstellungsinstituts unter http://eige. europa.eu/gender-mainstreaming (31.7.2018).

\section{Literatur}

Abels, Gabriele, 2011: 90 Jahre Frauenwahlrecht: Zum Wandel von Geschlechterverhältnissen in der deutschen Politik. In: Abels, Gabriele (Hg.): Deutschland im Jubiläumsjahr 2009: Blick zurück nach vorn. Baden-Baden, 197-219.

Ahrens, Petra/Scheele, Alexandra/van der Vleuten, Anna, 2016: 20 Jahre Vertrag von Amsterdam - reelle Vision oder reale Desillusion europäischer Gleichstellungspolitik? In: Femina Politica. Zeitschrift für feministische Politikwissenschaft. 25 (2), 9-21.

Blome, Agnes/Fuchs, Gesine, 2017: Macht und substantielle Repräsentation von Frauen. In: Femina Politica. Zeitschrift für feministische Politikwissenschaft. 26 (1), 55-69.

Bundesministerium des Innern, 2011: Gemeinsame Geschäftsordnung der Bundesministerien. GGO. Internet: http://www.verwaltungsvorschriften-im-internet.de/bsvwvbund_21072009 011313012.htm (31.7.2018).

Celis, Karen/Childs, Sarah, 2012: Research Note. The Substantive Representation of Women: What to do with Conservative Claims? In: Political Studies. 60, 213-225.

Celis, Karen/Erzeel, Silvia, 2015: Beyond the Usual Suspects. Non-Left, Male and Non-Feminist MPs and the Substantive Representation of Women. In: Government and Opposition. 50 (1), 45-64.

Childs, Sarah, 2004: New Labour's Women MP's: Women Representing Women. New York.

Childs, Sarah, 2015: The Good Parliament. Report. Bristol University.

Childs, Sarah/Krook, Mona L., 2008: Critical Mass Theory and Women's Political Representation. In: Political Studies. 56, 725-736.

Childs, Sarah/Krook, Mona L., 2009: Analyzing Women's Substantive Representation: From Critical Mass to Critical Actors. In: Government and Opposition. 44 (2), 125-145.

Davidson-Schmich, Louise K./Kürschner, Isabelle, 2011: Stößt die Frauenquote an ihre Grenzen? Eine Untersuchung der Bundestagswahl 2009. In: Zeitschrift für Parlamentsfragen. 42 (1), 25-34. 
Der Bundeswahlleiter, 2017a: Ergebnisse früherer Bundestagswahlen. Informationen des Bundeswahlleiters. Wiesbaden.

Der Bundeswahlleiter, 2017b: Wahl zum 19. Deutschen Bundestag am 24. September 2017. Heft 4. Wahlbeteiligung und Stimmabgabe der Frauen und Männer nach Altersgruppen. Statistisches Bundesamt. Informationen des Bundeswahlleiters. Wiesbaden.

Deutscher Bundestag, 2018: Abgeordnete in Zahlen. Internet: https://www.bundestag.de/ abgeordnete/biografien/mdb_zahlen_19\#url=L2FiZ2VvcmRuZXRIL2Jpb2dyYWZpZW4vbWRiX3 phaGxlbl8x0S9mcmF1ZW5fbWFlbm5lci81Mjk1MDg=\&mod=mod529494 (1.7.2018).

Eulers, Kathrin, 1991: Frauen im Wahlrecht. Möglichkeiten zur Verbesserung der Partizipation von Frauen im Bundestag. Baden-Baden.

Europäisches Parlament, 2018: Frauen im Europäischen Parlament. Luxemburg. Internet: http://www.europarl.europa.eu/germany/resource/static/files/service/l008519-bro-a4-de-dgpers-women-in-the-ep_web.pdf (22.7.2018).

Ferner, Elke (Hg.), 2008: 90 Jahre Frauenwahlrecht. Berlin.

Fokken, Silke, 2018: Deshalb dürfen Abgeordnete keine Elternzeit nehmen, Spiegel Online. Internet: https://www.spiegel.de/karriere/madeleine-henfling-warum-abgeordnete-keine-elternzeit-nehmen-duerfen-a-1225892.html (31.8.2018).

Franceschet, Susan/Krook, Mona Lena/Piscopo, Jennifer M. (Hg.), 2012: The Impact of Gender Quotas. Oxford.

Galligan, Yvonne/Meier, Petra, 2015: Report on Gender-Sensitive Parliaments in the European Union: Analysis. Unveröffentlichter Bericht, Queens University Belfast.

Günther, Jana, 2006: Die politische Inszenierung der Suffragetten in Großbritannien: Formen des Protests, der Gewalt und symbolische Politik einer Frauenbewegung. Freiburg.

Günther, Jana, 2017: Fragile Solidaritäten. Klasse und Geschlecht in der britischen und deutschen Frauenbewegung. Dissertation. Humboldt-Universität zu Berlin.

Kroeber, Corinna/Marent, Vanessa/Fortin-Rittberger, Jessica/Eder, Christina, 2018: Still a Glass Ceiling? Tracing the Limits to Women's Representation in Elected Office. In: Comparative European Politics. doi: dx.doi.org/10.1057/s41295-018-0114-5.

Krook, Mona Lena/Norris, Pippa, 2014: Beyond Quotas: Strategies to Promote Gender Equality in Elected Office. In: Political Studies. 62 (1), 2-20.

Kuhar, Roman/Paternotte David (Hg.), 2017: Anti-Gender Campaigns in Europe. Mobilizing against Equality. Lanham.

Lang, Sabine, 2004: Politik - Öffentlichkeit - Privatheit. In: Rosenberger, Sieglinde K./Sauer, Birgit (Hg.): Politikwissenschaft und Geschlecht. Wien, 65-81.

Lombardo, Emanuela/Meier, Petra, 2014: The Symbolic Representation of Gender. A Discursive Approach. Aldershot.

Murray, Rainbow, 2012: Parity and Legislative Competence in France. In: Franceschet, Susan/ Krook, Mona Lena/Piscopo, Jennifer M. (Hg.), 2012: The Impact of Gender Quotas. Oxford, 27-42.

Murray, Rainbow, 2014: Quotas for Men: Reframing Gender Quotas as a Means of Improving Representation for All. In: American Political Science Review. 108 (3), 520-532.

Niedermayer, Oskar, 2017: Parteimitglieder in Deutschland: Version 2017. In: Arbeitshefte aus dem Otto-Stammer-Zentrum. Nr. 27. Berlin.

Pawlowski, Rita (Hg.), 2008: Unsere Frauen stehen ihren Mann. Frauen in der Volkskammer der DDR 1950-1989. Ein biographisches Handbuch. Berlin.

Paxton, Pamela/Hughes, Melanie M., 2017: Women, Politics, and Power. A Global Perspective. 3. Auflage. Los Angeles u.a.

Pitkin, Hanna, 1967: The Concept of Representation. Berkeley u.a. 
Rosenbusch, Ute, 1998: Der Weg zum Frauenwahlrecht in Deutschland. Baden-Baden.

Sacchet, Teresa, 2008: Beyond Numbers. The Impact of Gender Quotas in Latin America. In: International Feminist Journal of Politics. 10 (3), 396-386.

Saward, Michael, 2009: Authorisation and Authenticity. Representation and the Unelected. In: Journal of Political Philosophy. 17 (1), 1-22.

Schmincke, Imke, 2018: Frauenfeindlich, sexistisch, antifeministisch? Begriffe und Phänomene bis zum aktuellen Antigenderismus. In: Aus Politik und Zeitgeschichte. 17, 28-33.

Schwindt-Bayer, Leslie A./Mishler, William, 2005: An Integrated Model of Women's Representation. In: The Journal of Politics. 67 (2), 407-428.

Teele, Dawn Langan, 2018: How the West Was Won: Competition, Mobilization, and Women's Enfranchisement in the United States. In: The Journal of Politics. 80 (2), 442-461.

Wängnerud, Lena, 2009: The Principles of Gender-Sensitive Parliaments. New York.

Xydias, Christina, 2014: Women's Rights in Germany: Generations and Gender Quotas. In: Politics \& Gender. 10 (1), 4-32.

\section{Feministische Repräsentationskritik: (Dis-)Kontinuitäten von den ersten deutschen Frauenbewegungen bis in die Gegenwart}

\section{ANNE CRESS}

Repräsentationskritik ist im feministischen politischen Denken und Handeln fest verankert - und dies nicht erst seit den 1970er Jahren. Vielmehr kann diese Kritik zumindest bis in das 19. Jahrhundert zurückverfolgt werden, wenn nämlich bislang marginalisierte Werke von Akteur_innen der deutschen Frauenstimmrechtsbewegungen „vom Rand in das Zentrum der Betrachtung“ (Conradi 2015, 107) gerückt werden. ${ }^{1}$ Auf diese Weise sollen wichtige Rezeptionslücken auch in der feministischen Repräsentationstheorie zumindest ein stückweit geschlossen werden. Vorrangiges Ziel ist es, die politische Ideengeschichte durch die Nachrezeption der Schriften aus der Frauenstimmrechtsbewegung zu bereichern. Die vergessenen, verleugneten und verschütteten politischen und vor allem denkerischen (Gegen-) Bestrebungen sollen so innerhalb der Politikwissenschaft erneut oder gar erstmalig Sichtbarkeit erlangen (Klinger 1986, 76).

Methodisch habe ich mich an dem von Elisabeth Conradi (2015) entwickelten Verfahren eines ,rekonstruierenden Quellenstudiums“" orientiert. Mittels einer archivarischen Recherche und unter Berücksichtigung der zeitgenössischen Forschung analysiere ich Schriften von Frauenstimmrechtsaktivistinnen in Bezug auf ihre Repräsentationskritik. Es lassen sich zunächst drei Varianten einer solchen Kritik identifizieren und entlang der Dimensionen ,externe“ und ,interne Repräsentationskritik“ unterscheiden: 
eine konservativ-gemäßigte, eine radikal-feministische und eine marxistisch-feministische Variante. ${ }^{2}$ Im zweiten Schritt gehe ich auf das Denken zeitgenössischer Theoretiker_innen ein, das ich idealtypisch in eine essentialistisch-output-orientierte und eine anti-essentialistisch-partizipatorische Variante unterteile, und frage nach theoretischen (Dis-)Kontinuitäten. Abschließend diskutiere ich das herrschaftskritische und transformative Potenzial feministischer Repräsentationskritik.

\section{Eine gemeinsame Sprache der Kritik?}

Auguste Kirchhoff $(1912,4)$ zufolge ist die Frauenstimmrechtsidee in Deutschland zum ersten Mal im Kontext der Revolution von 1848 aufgekommen. Sie sei anschließend jedoch in einen ,tiefen Dornröschenschlummer“ gefallen, aus dem sie Hedwig Dohm mit ihrem Werk „Der Frauen Natur und Recht“" (1876) befreit habe. ${ }^{3}$ Als weitere „Gründerinnen und Vorkämpferinnen“ nennt Kirchhoff $(1912,12)$ Lily v. Gyzicki, Minna Cauer, Anita Augspurg und Lida Gustav Heymann. Auch in der aktuellen Forschung zur Frauenstimmrechtsbewegung wurden lange Zeit v.a. die Leistungen der „radikalen“ Frauenbewegung betont. Seit Ende der 1990er Jahre wird dies jedoch von einigen Historiker_innen stark kritisiert, die z.B. den Einsatz der konservativ-gemäßigten Helene Lange für das Frauenstimmrecht hervorheben (Bock 1999; Bock 2018; Schaser 2009; Wolff 2018). Kerstin Wolff $(2018,38)$ vertritt die These, dass „der Kampf der deutschen bürgerlichen Frauenbewegung um das Stimmrecht ab Mitte der 1890er Jahre (...) als ein Gemeinschaftsprojekt aller Flügel und Richtungen zu verstehen (sei)“. Wolff (ebd., 46) argumentiert, dass es keine grundsätzliche Uneinigkeit über das Ziel, sondern nur über „taktische Herangehensweisen“ (ebd., 52) auf dem Weg zum Stimmrecht gegeben hätte. ${ }^{4}$ Auch Gisela Bock (1999, 191) behauptet: „,Der politische Diskurs des Suffragismus war grundsätzlich derselbe, sowohl im Vergleich der Radikalen und Gemäßigten innerhalb Deutschlands als auch im Vergleich zwischen deutschen und außerdeutschen Suffragistinnen.“Alle hätten die „Sprache der politischen Repräsentation“ (ebd.) gesprochen. Diese vermeintlich gemeinsame Sprache entpuppt sich, so meine These, bei genauerem Hinsehen jedoch als in sich äußerst differenziert. Meine Analyse der Frauenstimmrechtsideen zeigt, dass es durchaus nicht ,die' feministische Repräsentationskritik gab, sondern unterschiedliche Kritikvarianten, und es in den Konflikten um mehr ging als ,nur' um Taktikfragen. ${ }^{5}$ In Bezug auf Repräsentationskritik erweist sich die weit verbreitete, teilweise kritisierte Einteilung der Frauenstimmrechtsbewegung in drei distinkte Flügel (s.u.) durchaus als sinnvolle Heuristik.

\section{Feministische Repräsentationskritik im Kontext deutscher Frauenstimmrechtsbewegungen}

Eine Gemeinsamkeit der meisten Frauenstimmrechtsideen ist, dass sie den männlichen Repräsentationsanspruch bzw. die -fähigkeit in Frage stellen. Gleichwohl 
können in den drei Flügeln - konservativ-gemäßigter, radikal-feministischer und marxistisch-feministischer - unterschiedliche Spielarten einer Repräsentationskritik rekonstruiert werden. Diese unterscheiden sich sowohl hinsichtlich ihrer externen Repräsentationskritik, d.h. ihrer Kritik am männlichen Repräsentationsanspruch, als auch in Bezug auf ihre interne Repräsentationskritik, d.h. inwiefern sie ihre eigenen Repräsentationsansprüche selbstkritisch hinterfragen.

Konservativ-gemäßigte Repräsentationskritik

Helene Lange stellte in ihrem 1886 erschienenen Aufsatz fundamental die Fähigkeit des Mannes in Frage, die Frau zu repräsentieren:

Indem man von ihnen (Anmerk. AC: den männlichen Parlamentariern) verlangte, daß sie für die Frauen eintreten, sich in ihre Stelle versetzen sollten, verlangte man etwas, was gegen die Natur ist. Der einzelne, ethisch hochstehende Mann kann, von der Idee der Gerechtigkeit ergriffen, für die Frau eintreten wollen - in sie hineindenken kann auch er sich nicht. Nur die Frau versteht alle Bedürfnisse und Interessen ihres Geschlechts ganz, und wenn auch der Mann für die einzelne, geliebte Frau eintreten kann und wird, so kann nur die Frau die Frau als Geschlecht schützen. Und die einzige Form, in der das wirksam und auf Dauer geschehen kann, ist das Frauenstimmrecht (...), der Einfluss auf die Gesetzgebung. (Lange 1886, 183)

Ihr Plädoyer basierte auf der Annahme von essentialistisch verstandenen, spezifischen Interessen, Bedürfnissen, Sichtweisen und Fähigkeiten der Frau, die sich fundamental von denen des Mannes unterscheiden (Lange 1913, 72). Eine Repräsentation der Frau durch den Mann sei schlicht unmöglich. Zumal die Erfahrung zeige, ,daß überall, wo Männer im großen für die Fraueninteressen eingetreten sind, ihr eigener Vorteil im Hintergrund stand" (ebd., 182). So habe man Mädchen etwa eine bessere Bildung zugestanden, damit sich der Mann später mit seiner Ehefrau nicht allzu sehr langweilen müsse. Lange ging es nicht allein um Interessenspolitik, sondern vielmehr um die Wohlfahrt des gesamten Volkes (Lange 1912, 108f.), denn sie schrieb der Frau gemäß des Prinzips der „geistigen Mütterlichkeit" eine besondere „Kulturmission“ zu, die sie nur mithilfe des Stimmrechts vollumfänglich erfüllen könne (ebd.; vgl. Clemens 1988, 77). Die Frau solle in die Politik ideelle Werte hineintragen, die in ihrem „Instinkt der Mutterschaft“ und ihrer „unmittelbare(n) Fühlung mit der Natur" gründen (Lange 1886, 188). Insbesondere im Bereich der Sozialpolitik (z.B. öffentliche Erziehung, Armenpflege) habe sich „diese Mutterliebe“ als von Nöten erwiesen, um Probleme wie Alkoholismus, Verarmung, Jugenddelinquenz oder Prostitution erfolgreich zu bewältigen (ebd., 186). Basierend auf dieser identitätslogischen Argumentation kritisierte Lange den ,rein männliche(n) Staat in seiner starren Einseitigkeit“ (ebd., 188); sie forderte stattdessen das verständigungsorientierte Zusammenwirken beider Geschlechter, die sich mit ihrer jeweiligen Eigenart gegenseitig ergänzen würden und ihre je spezifischen Qualitäten im Sinne des wahrhaft öffentlichen Wohls einsetzen sollten (ebd., 186, 188, 194f.). 
Differenzen innerhalb der Gruppe der Frauen problematisierte Lange nicht; der eigene Anspruch, ,die Frau' repräsentieren zu können, wurde von ihr nicht kritisch hinterfragt. Dieser Mangel an interner Repräsentationskritik ist für weite Teile der bürgerlichen Frauenbewegung charakteristisch. So war das anwaltschaftliche Handeln für Arbeiterinnen weitgehend unumstritten (Bäumer 1901, 36). Louise Otto $(1848,71)$ sah es gar als ihre ,,heiligste Pflicht (an), der Sache Derer, welche nicht den Muth haben, dieselbe zu vertreten, (...) ihre Stimme zu leihen“. Sie legitimierte ihr Repräsentationshandeln ebenfalls identitätslogisch - „Ich bin gewiss, meine armen Schwestern theilen meine Gefühle“ (ebd.) - sowie über die Annahme, dass Arbeiterinnen aufgrund ihrer prekären Lebenssituation nicht dazu in der Lage sind, für sich selbst zu sprechen.

\section{Radikal-feministische Repräsentationskritik}

Die radikal-feministische Kritik argumentierte anders. Eine legitime Repräsentation von Frauen durch Männer wurde nicht prinzipiell ausgeschlossen, aber es wurde bemängelt, dass das männliche Repräsentationshandeln vollkommen losgelöst von jeglicher Partizipation der Frau erfolge. Bereits 1876 wendete sich Hedwig Dohm gegen die vorherrschende Meinung, die Frau werde durch den Mann mitrepräsentiert $^{6}$ :

Wann übertrug die Frau dem Manne das Mandat? Wann legte er ihr Rechenschaft von seinen Beschlüssen ab? Weder das eine noch das andere ist jemals geschehen. Wenn die Frauen nicht einverstanden sind mit dieser Vertretung, so ist eine Behauptung wie die angeführte eine beleidigende sociale Improvisation der Männer, ein Hohn in's Antlitz der realen Verhältnisse. (Dohm 1876, 126)

Dohm fokussierte auf das Fehlen einer unmittelbaren Legitimierung durch die Repräsentierten und bediente sich damit eines klassisch-demokratietheoretischen Arguments, wenngleich dessen Anwendung bis dato und auch darüber hinaus keineswegs üblich war; denn es war keine Selbstverständlichkeit, Frauen als eigenständige Persönlichkeiten anzuerkennen, die dazu berechtigt und befähigt sind, unmittelbar an der Weltgestaltung mitzuwirken. Marie Baumgarten $(1914,41)$ nahm den Faden Dohms später auf und kritisierte die Männer dafür, dass sie für und über Frauen sprächen, ohne diese ,selbst reden (zu) lassen, wie es (...) (ihnen) dabei zu Mute ist, ob es ihren Wünschen entspricht“. Die radikalen Frauen forderten nicht mehr und nicht weniger als das Recht, für sich selbst sprechen zu dürfen. Sie kämpften für die Möglichkeit „ein(es) aktive(n) und innerlich freie(n) Leben(s) als Bürgerin des Staates“ (Solltmann 1917, 22).

Sie waren sich zudem der Heterogenität innerhalb der Gruppe der Frauen um einiges bewusster als der konservativ-gemäßigte Flügel. Sie thematisierten v.a. Klassenunterschiede und lehnten einen auf Harmonie und Einheit bedachten ,Reinfeminismus - wie er z.B. von der konservativ-gemäßigten Paula Schindler (1913) von der Deut- 
schen Vereinigung für Frauenstimmrecht vertreten wurde - ab, denn die Radikalen wollten sich nicht darauf beschränken, nur die „Beseitigung derjenigen Einschränkungen und Ungerechtigkeiten (zu fordern), die die Frau wegen ihres Geschlechts treffen" (ebd., 35). Vielmehr setzten sie sich für eine umfassende Demokratisierung der (Welt-)Gesellschaft ein. ${ }^{7}$ Mittels des Stimmrechts sollte allen Gesellschaftsmitgliedern die Teilhabe am politischen Leben ermöglicht werden (Kulka 1914, 2). Konsequenterweise forderten die Radikalen das allgemeine und gleiche Wahlrecht. Sie waren davon überzeugt, dass ,an die Stelle der Entrechtung der Frau durch den Mann niemals die Entrechtung der Frau durch die Frau treten darf" (Kirchhoff 1912, 33). ${ }^{8}$ Radikale, wie Minna Cauer (1913), wollten die Frauenbewegung durch und durch „als eine demokratische Bewegung“ verstanden wissen und sorgten sich daher auch um deren interne Demokratie; sie beklagten Bevormundung sowie bürokratische Herrschaft (Cauer 1917b, 39). Ferner waren sie davon überzeugt, dass weder sie noch die Frauenbewegung als Ganzes ,im Namen der ganzen Frauenwelt (...) handeln, (...) Prinzipien verkünden und diese als (...) anerkannt hinstellen (konnten)" (Cauer 1917a, 38). Deswegen hielten sie es auch für einen Irrtum, dass die Gemäßigten meinten, sie könnten das gesamte Geschlecht vertreten. Trotz oder gerade wegen aller Zurückhaltung gegenüber der Repräsentation anderer, rangen die Radikalen um ein gelingendes solidarisch-verantwortliches Handeln. Anstatt egoistische Klasseninteressen zu verfolgen, wollten sie auch für die Rechte der Arbeiterin kämpfen (Cauer 1916, 14). Tony Breitscheid $(1909,14)$ schreibt: „Wir, die wir die ,bürgerlichen Frauen' genannt werden, wollen kein Vorrecht vor den Arbeiterinnen, wir wollen Gleichberechtigung. Und wenn sie auch in anderen Organisationen stehen, so wollen wir doch auf das gleiche Ziel gehen und müssen uns auf dem Weg gegenseitig unterstützen." In ähnlicher Weise appellierte Lilly Braun (geb. Gizycki) bereits 1895 an die Verantwortung der (bürgerlichen) Frauen, ,in den Kampf für die leidende Menschheit einzutreten“" (Gizycki 1895, 24).

\section{Marxistisch-feministische Repräsentationskritik}

Die Proletarier_innen waren skeptisch gegenüber solchen Solidaritätsbekundungen. $\mathrm{Zu}$ groß schienen die soziale Ungleichheit und die Interessensgegensätze. Insbesondere Clara Zetkin $(1907,32)$ zweifelte die Bereitschaft all der „,edelsteinübersäten Damen (...) (an,) gegen ihre eigene Klasse und deren wirtschaftliche, soziale und politische Vorrechte (zu kämpfen) (...), (d.h.) gegen soziale Zustände, denen sie selbst ihre Muße, ihre Bewegungsfreiheit, ihre Bildung und ihren Luxus verdanken“. Die Bündnisfähigkeit der bürgerlichen Frauen war folglich umstritten (Richebächer 1982, 132). Das „schöne frauenrechtlerische Lirum Larum von der ,einen großen Schwesternschaft““ (Zetkin 1907, 13) sowie „das theoretische Märchen von der einen unteilbaren Frauenbewegung" (ebd., 17) wurden kritisiert. Zetkin beklagte zudem, dass sich die Forderungen der Radikalen nicht hinreichend in ihrer politischen Praxis widerspiegeln würden (ebd., 16f.). Allerdings schlossen nicht alle Akteur_in- 
nen der proletarischen Frauenbewegung prinzipiell eine Zusammenarbeit mit jenen Bürgerlichen aus, die für das allgemeine Frauenwahlrecht kämpfen wollten (Notz 2008, 29). So fand etwa ein gemeinsamer Protest für das Wahlrecht am 19.03.1911, dem ersten Internationalen Frauentag, statt (ebd., 34).

Am Repräsentationsanspruch der Arbeiter gegenüber den Arbeiterinnen wurde von Seiten der Proletarier_innen hingegen nur zögerlich Kritik geübt. Dies mag unterschiedliche Gründe gehabt haben. Zum einen sahen sie im Frauenwahlrecht in erster Linie ein Mittel im gemeinsamen Kampf gegen den Kapitalismus. Zum anderen war die Arbeiterbewegung insgesamt von einer hegemonialen Männlichkeit durchdrungen (Welskoop 2000, 335ff.), was eine solche Kritik sicherlich erschwerte. Aber - so formuliert es die ungarische Feministin und Frauenstimmrechtlerin Rosika Schwimmer $(1907,155)$ - , ,auch den sozialistischen Frauen dämmerte es, daß in dem ständigen Unterordnen der speziellen Fraueninteressen unter die der ,Allgemeinheit des Proletariats' eine tüchtige Portion Männerklasseninteresse steckt(e)“‘.

\section{Zeitgenössische feministische Repräsentationskritik: Zwei idealtypische Varianten}

Die Institutionalisierung des allgemeinen und gleichen Wahlrechts 1918 stellt ohne Zweifel einen bedeutenden Meilenstein dar auf dem Weg der Befreiung der Frauen „,von den künstlichen Fesseln“ (Chapmann-Catt 1913, 14) und ,aus den großen Gefängnissen, die für die Frauenschaft die Welt bedeuteten“ (Dohm 1910, 3). Sollte Dohm also mit ihrer 1876 formulierten Annahme Recht behalten, dass Frauen durch das Erlangen des Stimmrechts dazu ermächtigt würden, ihre Unterdrückung aufzuheben und Freiheit, Ebenbürtigkeit sowie Selbstständigkeit zu verwirklichen (Dohm 1876, 183)? Die Antwort fällt angesichts der nach wie vor bestehenden (vergeschlechtlichten) Herrschaftsverhältnisse ambivalent aus. Gabriele Abels (2011, 217) betont, welch beeindruckende Entwicklung die Geschlechterverhältnisse in Deutschland seit der Zeit der Frauenstimmrechtsbewegung durchlaufen haben; gleichwohl sei ,einzuräumen, dass wir von einer echten Geschlechterparität immer noch entfernt sind."

Vielfältige Demokratiedefizite werden innerhalb (feministischer) Politikwissenschaft sowie politischer Praxis intensiv diskutiert. Immer noch versuchen frauenbewegte Akteur_innen und feministische (Politik-)Wissenschaftler_innen den geschlechtsbezogenen Hindernissen politischer Gleichheit und Freiheit mittels Repräsentationskritik auf die Spur zu kommen. Auch gegenwärtig gibt es nicht ,die“ feministische Repräsentationskritik, sondern eine Vielfalt an Stimmen. Dies hängt u.a. mit divergierenden Demokratie- und Politikverständnissen sowie Geschlechterund Erkenntnistheorien zusammen. Im Folgenden vertrete ich die These, dass es zwei idealtypische Varianten zeitgenössischer feministischer Repräsentationskritik gibt, die unterschiedliche Kontinuitäten bzw. Diskontinuitäten mit der , alten ‘ Kritik aufweisen. 
Gemäß der vorherrschenden liberalen Demokratietheorie besteht eine zentrale Funktion eines jeden demokratischen politischen Systems darin, für eine Bündelung sowie für eine rationale Übertragung der Bürger_inneninteressen in Politik (policy) zu sorgen. Repräsentation wird mit Interessenvertretung gleichgesetzt. Ein Repräsentationsproblem besteht, laut diesem output-orientiertem Demokratieverständnis, sofern die Interessen der Bürger_innen keine adäquate Berücksichtigung finden und darunter sowohl die demokratische Legitimität des politischen Systems als auch die Qualität der Politikergebnisse leidet. In dieser Tradition verhaftete feministische Politikwissenschaftler_innen sind dementsprechend an der Frauenfreundlichkeit der Politikergebnisse interessiert. Von Belang ist, inwiefern Fraueninteressen im politischen Prozess durch- und umgesetzt werden können (Blome/Fuchs 2017, 57). Eine zentrale Annahme lautet, dass Frauen - als eine eigene, anzuerkennende Interessensgruppe - aufgrund des hierarchischen Geschlechterverhältnisses und der damit verbundenen sozialen Ungleichheiten strukturell benachteiligt und politisch exkludiert werden. Ähnlich wie Lange unterstellen einige, dass die Berücksichtigung von Fraueninteressen ausschließlich oder zumindest in besonderer Weise durch Frauen erfolgen könne (Sauer 2011, 127; Wängnerud 2009, 65). Im Unterschied zum wissenschaftlichen Mainstream ist somit nicht nur das Was der Repräsentation von Interesse, sondern der Inhalt hängt unweigerlich mit dem Wer - also dem Subjekt des Repräsentationshandelns - zusammen.

Diese Annahme baut in der Regel auf einer (dualistisch-)essentialistischen Theorie der Geschlechterdifferenz auf. Frauen werden als homogene Gruppe mit spezifischen Sichtweisen, Themen, Problemen und Interessen betrachtet, welche erfahrungsbasiert und somit in erster Linie Frauen selbst vorbehalten sind. Zugleich wird diesem exklusiven Wissen eine große Bedeutung für die Transformation der Gesellschaft und insbesondere für die Befreiung der Frau zugeschrieben (Hartsock 1983, 289, 304). Für die Standpunkt-Theoretikerin Nancy Hartsock (ebd., 284) gründet das Besondere der weiblichen Erfahrung in der geschlechtlichen Arbeitsteilung. Auch andere nennen geschlechtsbezogene sozio-ökonomische Positionen und/oder biologische Differenzen als Quelle (Wängnerud 2009, 53; Sapiro 1981, 166; Phillips 1998, 233).

Ausgehend davon wird der geringe Frauenanteil in staatlichen Institutionen kritisiert und eine zahlenmäßige Verbesserung deskriptiver Repräsentation, z.B. mittels Quoten, eingefordert. Gleichwohl wird in diesen Studien oftmals nicht expliziert, warum numerische Unterpräsenz aus demokratie- bzw. geschlechtertheoretischer Perspektive ein Problem darstellt (Wängnerud 2009, 53). Der Zusammenhang zwischen deskriptiver Repräsentation - verstanden als Präsenz von Frauen in politischen Entscheidungsprozessen - und substanzieller Repräsentation - gemessen an der Frauenfreundlichkeit der Ergebnisse - ist innerhalb der feministischen Repräsentationsforschung sehr wohl umstritten (Sauer 2011, 129). Frauen handeln nicht 
immer zu Gunsten ihres Geschlechts (to act for women) und mehr weibliche Abgeordnete führen nicht zwangsläufig zu einem Politikwandel im Sinne bestimmter, feministisch-normativer Positionen (Childs/Krook 2008, 21f.). Zudem wird die präpolitische Existenz von spezifischen, universal-gültigen Fraueninteressen von Seiten einer anti-essentialistisch-partizipatorischen Repräsentationskritik massiv in Frage gestellt.

In gewisser Weise zeichnet sich zwischen dieser essentialistisch-output-orientierten Repräsentationskritik und der ,alten“ konservativ-gemäßigten Kritikvariante eine Kontinuitätslinie ab. Beide begegnen männlichen Repräsentationsansprüchen gegenüber Frauen grundsätzlich mit Skepsis oder halten sie aufgrund einer diesbezüglich präsumierten Repräsentationsunfähigkeit des Mannes sogar für prinzipiell illegitim und unbegründet (Phillips 1998, 234; Diamond/Hartsock 1981, 198). Hingegen haben sie in der Regel kein Problem damit, wenn eine kleine Gruppe von Frauen oder womöglich eine einzelne Frau den Anspruch erhebt, für und über die Frau im Allgemeinen sprechen zu können. Eine (gruppen-)interne Repräsentationskritik ist ihnen weitgehend fremd.

\section{Die anti-essentialistisch-partizipatorische Repräsentationskritik}

Insbesondere intersektionale, postkolonial-feministische sowie queer-feministische Ansätze weisen Vorstellungen von universellen weiblichen Erfahrungen und Interessen entschieden zurück. Die Idee der universellen Schwesternschaft entpuppt sich als ein Versuch, Vielfältiges und Widersprüchliches zu vereindeutigen (Lorey 1998, 102). Die postkolonial-feministische Kulturwissenschaftlerin Ien Ang (1995, 191) konstatiert: „not all women share the same experience of ,being a women', nor is a shared gender enough to guarantee a commonality on social positioning". Die Gruppe der Frauen ist aus unterschiedlichen Gründen in sich heterogen. Neben dem Geschlecht bestehen weitere relevante soziale Strukturkategorien, die auf vielfältige Weise miteinander verwoben sind, wie etwa: Sexualität, Ethnizität (race), Klasse oder (Dis-)Ability. Zudem wird bezweifelt, dass es feste, unveränderbare, wesenhafte Identitäten gibt, „die als Essenz den Kern der Frau, der Lesbe, des Mannes etc. ausmachen“ (Lorey 1998, 93). Vielmehr ist die „Position, von der aus frau/man spricht, (zwar) durch historisch spezifische Praktiken und Diskurse konstituiert (...) (, aber) niemals endgültig und fest (ist)“ (ebd., 111). In dieser Variante wird unter politischer Repräsentation nicht nur das Sprechen-für-andere (Stellvertretung), sondern explizit auch das Sprechen-über-andere (Darstellung) verstanden; beide Phänomene sind schwer voneinander abzugrenzen und werfen durchaus ähnliche Fragen auf (Alcoff 1991, 9). Zudem werden auch non-verbale Darstellungsformen (z.B. Bilder) für politisch relevant erachtet.

Damit wird politische Repräsentation zu einem grundsätzlichen Problem. Die substanzielle Schwierigkeit besteht darin, dass die Repräsentierten in der Regel als politisches Subjekt konstituiert werden, d.h. als Einheit mit gemeinsamen Interessen, 
Forderungen oder Perspektiven. Dieses Gemeinsame - sprich das Objekt der Repräsentation - ist jedoch nicht einfach gegeben und kann daher auch nicht ohne weiteres abbildungslogisch repräsentiert werden (Castro Varela/Dhawan 2004, 209). Es kann allenfalls in einem politischen, konflikthaften Prozess konstruiert werden. Damit drängt sich die nur schwer zu beantwortende Frage auf, wer auf welche Weise an diesen Prozessen beteiligt gewesen sein sollte. Jede (Gruppen-)Repräsentation birgt letztlich die Gefahr, über die Homogenisierung von Heterogenität in Exklusion zu münden (Disch 2015, 490).

Die anti-essentialistisch-partizipatorische Repräsentationskritik zielt hingegen darauf ab, bislang Marginalisierten und Ausgeschlossenen Partizipationsmöglichkeiten zu eröffnen (Dhawan/Castro Varela 2016, 12). Anstatt weiterhin als prinzipiell partizipationsunfähige Objekte adressiert zu werden, sollen sie als (potenzielle) politische Subjekte Anerkennung finden, die ,define their own reality, establish their own identities, name their history“ (hooks 1989, 42; vgl. auch Collins 1990, 95; Hanock 2016, 12). Das fragliche, komplexe Ich, das ,sich weigert einen Minderheitenstatus oder gelebten Ort der Prekarität zugunsten eines anderen in den Hintergrund treten zu lassen“ (Butler 2016, 93), ist zu würdigen. Diese herrschaftskritische Priorisierung von Partizipation ist für die feministische politische Theorie und Praxis durchaus charakteristisch (Sauer 2011, 126).

Ausgehend von dieser normativen Präferenz gründet die potenzielle Gewaltförmigkeit politischer Repräsentation darin, dass die Repräsentierten am Repräsentationsakt selbst nicht unmittelbar beteiligt sind (Pitkin 1967, 9; Castro Varela/Dhawan 2013, 270). Nicht sie sind es, die in diesem Moment sprechend und handelnd an der gemeinsamen Gestaltung der Gesellschaft partizipieren, sondern die Repräsentant_innen, die für und über sie sprechen. Wenn diese ihre direkte Verbindung zu den Repräsentierten nahezu gänzlich verlieren, bewusst kappen oder erst gar nie hatten, können sie womöglich von diesen losgelöst, weitgehend autonom als elitär Herrschende agieren (Young 2000, 129). Repräsentation und Partizipation stehen somit zwangsläufig in einem spannungsreichen Verhältnis.

Je nach Gestalt der Repräsentationsbeziehung ist das Handeln der Repräsentant_innen als legitim oder illegitim, als begrüßenswert oder kritikwürdig zu bewerten (Young 2000, 128). Von Relevanz ist die Art, also ob Repräsentant_innen und Repräsentierte überhaupt in Kontakt stehen. Sofern dies der Fall ist, ist ferner die Qualität der Repräsentationsinteraktion, ihr Gelingen und die Rückbindung an die Repräsentierten zu untersuchen. Das Sprechen-für kann nur dann gelingen - und legitim sein -, wenn zuvor in der Interaktion eine gemeinsame Perspektive, ein gemeinsames Interesse oder eine gemeinsame Meinung herausgebildet oder identifiziert wurde (ebd., 129).

Vertreter_innen einer anti-essentialistisch-partizipatorischen Repräsentationskritik fragen zudem nach der Verteilung von Repräsentationsmöglichkeiten: Wer kann wen, wann und wie repräsentieren? Sie stellen fest: Nicht jede_r hat gleichermaßen die Möglichkeit andere zu repräsentieren, weil es eben nicht allen, sondern nur 
„einigen Wenigen gestattet wird, sich an öffentlichen Orten zu artikulieren“ (Castro Varela/Dhawan 2004, 212). Angehörige privilegierter sozialer Gruppen können nicht nur jeder Zeit für sich selbst die Stimme erheben, sondern sind zudem in der Lage, „den Anderen (,Nicht-Privilegierten'; AC) zu repräsentieren und sich damit Respekt und Geltung zu verschaffen“ (ebd.). Patricia Hill Collins (1990, 26) macht auf die diskursive Dominanz der Erfahrungen, Perspektiven und Interpretationen Privilegierter aufmerksam, die mitunter kaum Raum für abweichende Sichtweisen und Erzählungen lässt. Selbst wenn unterdrückte soziale Gruppen eine Äußerung tätigen und diese von anderen registriert wird, gelingt es ihnen oftmals nicht, sich verständlich zu machen (Steyerl/Rodriguez 2013, 7). Ihrem Sprechen wird nicht selten ,durch Nicht-Zuhören widerstanden“(Castro Varela 2007, 261).

Schließlich sind die politischen Effekte des Repräsentationshandelns in den Blick zu nehmen. Hierbei ist vor allem von Interesse, wie sich das Sprechen für und über die Repräsentierten auf deren politische Partizipationsmöglichkeiten - auch jenseits der konkreten Repräsentationsbeziehung - auswirkt. Die politische Relevanz der Repräsentationspraxen ist nicht nur darin begründet, dass von dem produzierten und vermittelten Wissen über die Repräsentierten etwa Problemdefinitionen sowie politische Lösungsvorschläge (policies) abgeleitet werden, sondern sie wird auch an den normierenden und normalisierenden Effekten dieser Darstellungen festgemacht (Lorey 1998, 100). Die Repräsentationen können sich auf die Anerkennung zukünftiger Repräsentationsansprüche auswirken, indem sie die Möglichkeiten einschränken, eine andere (politische) Subjektivität zum Ausdruck zu bringen (Castro Varela/Dhawan 2004, 208). Eine diskursive Festschreibung der Subjektposition Frau kann einige Frauen politisch sichtbar, andere unsichtbar machen (ebd., 209). Castro Varela und Dhawan sprechen davon, dass so „Exklusionsformen generiert (werden), die gewaltvolle regulatorische Konsequenzen hervorbringen“" (ebd., 208). So wird beispielsweise in feministischen Diskursen des globalen Nordens ein Bild von der emanzipierten Frau gezeichnet, das zwar die Anerkennung und Befreiung einiger Frauen unterstützt und legitimiert, aber zugleich andere Frauen ausschließt, die nicht diesem Bild entsprechen, weil sie z.B. ein Kopftuch tragen (ebd., 207).

Im Vergleich zur alten Frauenstimmrechtsbewegung hat sich heute insbesondere die interne Repräsentationskritik weiter ausdifferenziert und intensiviert, besonders in der anti-essentialistisch-partizipatorischen Variante. Allerdings war diese Kritik - zumindest in Ansätzen - in der ,alten' radikal- und marxistisch-feministischen Repräsentationskritik bereits angelegt (s.o.). Mit der radikal-feministischen Repräsentationskritik teilt die zeitgenössische Kritikvariante zudem die Ablehnung eines ,Reinfeminismus' sowie die normativ-herrschaftskritische Priorisierung politischer Partizipation. Mit Blick auf die verschiedenen deutschen Frauenstimmrechtsbewegungen fällt aus heutiger Perspektive noch etwas auf: Immer noch wird innerhalb feministischer Politik und Wissenschaft - trotz oder gerade wegen der intensivierten Repräsentationskritik - um die (Un-)Möglichkeit von politischen Bündnissen und solidarischem Handeln sowie um einen kritischen Umgang mit den jeweils eigenen 
Privilegien gerungen (siehe etwa Butler 2016). Insofern lassen sich im feministischen Denken durchaus beachtliche Kontinuitäten ausmachen.

\title{
Das herrschaftskritische und transformative Potenzial feministischer Repräsentationskritik
}

\author{
„Jahrelang haben wir selbst im Stimmrecht das Endziel \\ aller unserer Bestrebungen erblickt, \\ bis wir lernten, daß auch dies Ziel ein neuer Anfang ist. “ \\ (Kirchhoff 1912, 13)
}

Die formal-rechtliche politische Gleichheit aller deutscher Staatsbürger_innen wurde zwar mit der Institutionalisierung des allgemeinen und gleichen Wahlrechts vor 100 Jahren erreicht, sie kann aber durch diverse strukturelle Exklusionsmechanismen unterwandert werden. ${ }^{9}$ Die Erweiterung des Stimmrechts alleine kann nicht sicherstellen, dass unterdrückte soziale Gruppen (Frauen*, People of Color, Menschen mit Behinderung etc.) eine politische Stimme haben. Ungeachtet ihres formalrechtlichen Status als gleichberechtigte Bürger_innen können sie innerhalb politischer Diskurse auf unterschiedliche Weise „mundtot gemacht oder marginalisiert“ (Young 1993, 286) und somit in ihrer Sprechfähigkeit massiv eingeschränkt werden. Feministische Repräsentationskritiken können ein wirksames Instrument für die Realisierung politischer Gleichheit darstellen. Mit ihrer Hilfe können Repräsentationspraxen in ihrer Komplexität, in ihren vielfältigen Erscheinungsformen sowie mit den ihnen inhärenten Ambivalenzen theoretisiert werden. Die hier dargestellten Kritikvarianten können zum Aufdecken oftmals verschleierter Herrschaftsverhältnisse beitragen. Mit ihnen gerät in den Blick, dass es nach wie vor innerhalb und außerhalb von Frauenbewegungen Akteur_innen gibt, die im politischen Diskurs für andere sprechen. Nicht selten präsentieren sie sich explizit oder implizit als Anwält_innen, die insbesondere jenen Frauen eine Stimme verleihen, die sonst keine hätten (Lorey 2012, 184). Sie sprechen etwa für und über von Gewalt betroffene Frauen, Migrant_innen oder auch Sexarbeiter_innen. (Postkolonial-)Feministische Theoretiker_innen thematisieren die (potenzielle) Gewaltförmigkeit derartiger interner und externer Repräsentationspraxen und brechen mit der weitverbreiteten Annahme, Repräsentation sei per se etwas Gutes bzw. würde nur Gutes bewirken - oder sei zumindest nicht kritikwürdig. Feministische Repräsentationskritik kann somit Demokratiedefizite aufdecken. Aus einer feministisch-herrschaftskritischen Perspektive besteht weiterhin die Notwendigkeit, an einem radikaldemokratischen Projekt zu arbeiten, das jegliche Form der Prekarität bekämpft und mit dem Anspruch antritt, ,dass Leben gleich behandelt werden und gleich lebbar sein sollten“ (Butler 2016, 92). 


\section{Anmerkungen}

1 Ich adressiere die Akteur_innen der Frauenstimmrechtsbewegung somit explizit auch als politische Denker_innen und nicht, nur' als Aktivist_innen. Ihr politisches Denken hat sich u.a. aufgrund ihrer inneruniversitären Marginalisierung vor allem im Rahmen von selbst herausgegebenen Zeitschriften und Schriften publizistisch niedergeschlagen (Conradi 2015, 99). Damals wie heute besteht zudem zwischen feministischer Wissenschaft und dem politischem Projekt „Feminismus“ eine enge, wenngleich auch nicht spannungsfreie Verwobenheit (Krause 2003, 26f.).

2 Ich habe v.a. die Schriften von Lange und Zetkin sowie die Zeitschrift für Frauenstimmrecht (Jahrgang 1913-1918) analysiert. Meinen Thesen zur konservativ-gemäßigten Repräsentationskritik wurde durch eine punktuelle Sichtung der Zeitschrift Die Frau (Jahrgang 1887/881919/20) validiert. Weitere Quellen können dem Literaturverzeichnis entnommen werden. Die Analyse der marxistisch-feministischen Repräsentationskritik ist im Vergleich etwas kurz gekommen. Hier wäre eine Sichtung der Zeitschrift Die Gleichheit erforderlich.

3 Dohm hatte das Frauenstimmrecht erstmalig 1873 in ihrer Schrift „Der Jesuitismus im Hausstande. Ein Beitrag zur Frauenfrage“ öffentlich gefordert (Gerhard 1990, 105).

4 Ähnlich argumentiert Lange (1913) selbst.

5 Innerhalb der bürgerlichen Frauenstimmrechtsbewegung existierten 1914 drei Organisationen mit unterschiedlicher Ausrichtung (Cauer 1914; Heymann 1941, 111): Der Deutsche Verband für Frauenstimmrecht (gemäßigt, aber ursprünglich radikal); 1902 gegründet von Anita Augspurg, Lida Gustava Heymann, Minna Cauer u.a.; zunächst als Deutscher Verein für Frauenstimmrecht bis 1904), die Deutsche Vereinigung für Frauenstimmrecht (konservativ; gegründet 1911), und der Deutsche Bund für Frauenstimmrecht (radikal; 1913 gegründet von Augspurg, Heymann, Cauer u.a.). Die ersten beiden schlossen sich im März 1916 unter der Leitung von Marie Stritt zum Deutschen Reichsverband für Frauenstimmrecht zusammen (Schüller 2005, 197). Der Hauptkonflikt zwischen den verschiedenen Strömungen entfachte sich an der Frage, welches Stimmrecht gefordert werden sollte: ,nur' das Frauenstimmrecht - im Sinne einer Angleichung an das jeweils bestehende Männerwahlrecht - oder das allgemeine, gleiche (Breitscheid 1909, 3). Überdies bestand Dissens, welcher Stellenwert dem Stimmrecht in der Gesamtschau der Bestrebungen der Frauenbewegung zukommen sollte und zu welchem Zeitpunkt welche Stimmrechtsforderung zu äußern sei (Clemens 1990, 60 , 83f.; Schüller 2005, 185).

6 Diese Schrift Dohms wird auch von Lange (1899) positiv rezipiert.

7 Unter den Radikalen war der internationale Gedanke weit verbreitet. Sie wollten i.d.R. nicht nur das Wohl ihres eigenen Volkes, sondern das der gesamten Welt im Blick haben (Heymann 1915). Zudem waren die Frauenstimmrechtsbewegungen international sehr gut vernetzt (Abels 2011, 203).

8 Wie ausgeprägt die selbstkritische Haltung unter den Radikalen tatsächlich war, müsste näher untersucht werden. Denn sie sahen sich etwa, trotz Abneigung gegenüber jeglicher Form von Bevormundung, durchaus dazu im Stande, .Ideale für das weibliche Geschlecht auf(zu) stellen, (...) für Ziele ein(zu)treten und für dieselben (zu) wirken“" (Cauer 1917a, 38).

9 Zur folgenreichen Problematik der Bindung von politischer Gleichheit an Staatsbürger_innenschaft statt an Herrschaftsbetroffenheit vgl. Benhabib 2016.

\section{Literatur}

Abels, Gabriele, 2011: 90 Jahre Frauenwahlrecht. Zum Wandel von Geschlechterverhältnissen in der deutschen Politik. In: Abels, Gabriele (Hg.): Deutschland im Jubiläumsjahr 2009. Blick zurück nach vorn. Baden-Baden, 197-219.

Alcoff, Linda, 1991: The Problem of Speaking for Others. In: Cultural Critique. 5 (Winter), 5-32. 
Ang, len, (1995) 2004: I'm a Feminist but ... Other Women and Postnational Feminism. In: Lewis, Reina/Mills, Sara (Hg.): Feminist Postcolonial Theory. A Reader. New York, 190-206.

Bäumer, Gertrud, 1901: Die Geschichte der Frauenbewegung in Deutschland. In: Lange, Helene/ Bäumer, Gertrud (Hg.): Handbuch der Frauenbewegung. 1. Teil. Die Geschichte der Frauenbewegung in den Kulturländern. Berlin, 1-153.

Baumgarten, Marie, 1914: Muß die Frau das Stimmrecht haben. In: Zeitschrift für Frauenstimmrecht. 1. Juli 1914, 41-42.

Benhabib, Seyla, 2016: Demokratische Iterationen und demokratische Exklusionen. Eine Debatte über die gerechten Grenzen des Demos. In: Benhabib, Seyla: Kosmopolitismus ohne Illusionen. Menschenrechte in unruhigen Zeiten. Berlin, 191-234.

Blome, Agnes/Fuchs, Gesine, 2017: Macht und substantielle Repräsentation von Frauen. In: Femina Politica. Zeitschrift für feministische Politikwissenschaft. 26 (1), 55-69.

Bock, Gisela, 1999: Das politische Denken im Suffragismus. Deutschland um 1900 im internationalen Vergleich. In: Bock, Gisela: Geschlechtergeschichten der Neuzeit. Ideen, Politik, Praxis. Göttingen, Bristol, 168-203.

Bock, Gisela, 2018: 100 Jahre Frauenwahlrecht. Deutschland in transnationaler Perspektive. In: Zeitschrift für Geschichtswissenschaft. 66 (5), 395-412.

Breitscheid, Tony, 1909: Die Notwendigkeit der Forderung des allgemeinen, gleichen, direkten, geheimen Wahlrechts. Berlin.

Butler, Judith, 2016: Anmerkung zu einer performativen Theorie der Versammlung. Berlin.

Castro Varela, Maria do Mar, 2007: Unzeitgemäße Utopien. Migrantinnen zwischen Selbsterfindung und Gelehrter Hoffnung. Bielefeld.

Castro Varela, Maria do Mar/Dhawan, Nikita, 2004: Horizonte der Repräsentationspolitik - Taktiken der Intervention. In: Roß, Bettina (Hg.): Migration, Geschlecht und Staatsbürgerschaft. Perspektiven für eine anti-rassistische und feministische Politik und Politikwissenschaft. Wiesbaden, 205-226.

Castro Varela, Maria do Mar/Dhawan, Nikita, 2013: Postkolonialer Feminismus und die Kunst der Selbstkritik. In: Steyerl, Hito/Gutiérrez Rodriguez, Encarnación (Hg.): Spricht die Subalterne deutsch? Migration und postkoloniale Kritik. Münster, 270-290.

Cauer, Minna, 1913: Antwort. In: Zeitschrift für Frauenstimmrecht. 15. Juni 1913, 36.

Cauer, Minna, 1914: Drei Richtungen. In: Zeitschrift für Frauenstimmrecht. 15. Februar 1914, 11.

Cauer, Minna, 1916: Reflexion zur bürgerlichen Frauenstimmrechtsbewegung in Deutschland. In: Zeitschrift für Frauenstimmrecht. 1. April 1916, 13-14.

Cauer, Minna, 1917a: Majoritäten und Minoritäten. In: Zeitschrift für Frauenstimmrecht. 1. u. 15. September 1917, 38.

Cauer, Minna, 1917b: Offene Antwort an Fräulein Lohmann. In: Zeitschrift für Frauenstimmrecht. 1. u. 15. Oktober 1917, 39-40.

Chapmann-Catt, Carrie, 1913: Aufruf zum VII. Kongreß des Weltbundes für Frauenstimmrecht. In: Zeitschrift für Frauenstimmrecht. 1. März 1913. Berlin, 14-15.

Childs, Sarah/Krook, Mona Lena, 2008: Theorizing Women's Political Representation. Debates and Innovations in Empirical Research. In: Femina Politica. Zeitschrift für feministische Politikwissenschaft. 17 (2), 20-30.

Clemens, Bärbel, 1988: Menschenrechte haben kein Geschlecht! Zum Politikverständnis der bürgerlichen Frauenbewegung. Pfaffenweiler.

Clemens, Bärbel, 1990: Der Kampf um das Frauenstimmrecht in Deutschland. In: Wickert, Christl (Hg.): Heraus mit dem Frauenwahlrecht. Die Kämpfe der Frauen in Deutschland und England um die politische Gleichberechtigung. Pfaffenweiler, 51-131. 
Collins, Patricia Hill, 1990: Black Feminist Thought. Knowledge, Consciousness, and the Politics of Empowerment. Boston.

Conradi, Elisabeth, 2015: Rekonstruierendes Quellenstudium und Nachrezeption. Wie die politische Ideengeschichte zu bereichern ist. In: Reese-Schäfer, Walter/Salzborn, Samuel (Hg.): Die Stimme des Intellekts ist leise. Klassiker/innen des politischen Denkens abseits des Mainstreams. Baden-Baden, 85-111.

Dhawan, Nikita/Castro Varela, Maria do Mar, 2016: What Difference Does Difference make?. Diversity, Intersectionality and Transnational Feminist Politics. In: Wagadu. A Journal of Transnational Women's and Gender Studies. 16, 11-39.

Diamond, Irene/Hartsock, Nancy, (1981) 1998: Beyond Interests in Politics. A Comment on Virginia Sapiro's 'When Are Interests Interesting? The Problem of Political Representation of Women'. In: Phillips, Anne (Hg.): Feminism and Politics. Oxford, New York, 193-202.

Disch, Lisa, 2015: The Constructivist Turn in Democratic Representation. A Normative Dead-End? In: Constellations. 22 (4), 487-499.

Dohm, Hedwig, (1876) 1986: Der Frauen Natur und Recht. Zur Frauenfrage zwei Abhandlungen über Eigenschaften und Stimmrecht der Frauen. (Berlin), Neunkirch.

Dohm, Hedwig, 1910: Erziehung zum Frauenstimmrecht. Berlin.

Gerhard, Ute, 1990: Unerhört. Die Geschichte der deutschen Frauenbewegung. Reinbek.

Gizycki, Lily von, 1895: Die Bürgerpflicht der Frau. Vortrag gehalten in Dresden, Breslau und Berlin. Berlin.

Hanock, Ange-Marie, 2016: Intersectionality. An Intellectual History. New York.

Hartsock, Nancy C. M., 1983: The Feminist Standpoint. Developing the Ground for a Specifically Feminist Historical Materialism. In: Harding, Sandra/Hintikka, Merrill B. (Hg.): Discovering Reality. Feminist Perspectives on Epistemology, Metaphysics, Methodology, and Philosophy of Science. Dordrecht, 283-310.

Heymann, Lida Gustava, 1915: National-International. In: Zeitschrift für Frauenstimmrecht. 1. Februar 1915, 3-4.

Heymann, Lida Gustava, (1941) 1992: Erlebtes. Erschautes. Deutsche Frauen kämpfen für Freiheit, Recht und Frieden. 1850-1940. Unter Mitarbeit von Anita Augsburg. Frankfurt/M.

hooks, bell, 1989: Talking Back. Thinking Feminist, Thinking Black. Boston.

Klinger, Cornelia, 1986: Das Bild der Frau in der Philosophie und die Reflexion von Frauen auf die Philosophie. In: Hausen, Karin/Nowotny, Helga (Hg.): Wie männlich ist die Wissenschaft? Frankfurt/M., 62-84.

Kirchhoff, Auguste, 1912: Warum muß der Deutsche Verband für Frauenstimmrecht sich zum allgemeinen, gleichen, geheimen und direkten Wahlrecht bekennen? Bremen.

Krause, Ellen, 2003: Einführung in die politikwissenschaftliche Geschlechterforschung. Opladen

Kulka, Leopoldine, 1914: Das Prinzip der Neutralität. In: Zeitschrift für Frauenstimmrecht. 1. Januar 1914, 1-3.

Lange, Helene, (1896) 1928: Frauenwahlrecht. In: Lange, Helene: Kampfzeiten. Aufsätze und Reden aus vier Jahrzehnten. Erster Band. Berlin, 180-196.

Lange, Helene, 1899: Unsere „Alten“ und das Frauenstimmrecht. In: Die Frau. 7 (3), 129-133.

Lange, Helene, (1912) 1928: Frauen und Politik. In: Lange, Helene: Kampfzeiten. Aufsätze und Reden aus vier Jahrzehnten. Zweiter Band. Berlin, 101-117.

Lange, Helene, 1913: Der Weg zum Frauenstimmrecht. In: Die Frau. 21 (2), 65-76.

Lorey, Isabell, 1998: Dekonstruierte Identitätspolitik. Zum Verhältnis von Theorie, Praxis und Politik. In: Hornscheidt, Antje/Jähnert, Gabriele/Schlichter, Annette (Hg.): Kritische Differenzen - 
geteilte Perspektiven. Zum Verhältnis von Feminismus und Postmoderne. Opladen, Wiesbaden, 94-114.

Lorey, Isabell, 2012: Postkoloniale politische Theorie. In: Kreisky, Eva/Löffler, Marion/Spitaler, Georg (Hg.): Theoriearbeit in der Politikwissenschaft. Wien, 175-187.

Notz, Gisela, 2008: Her mit dem allgemeinen, gleichen Wahlrecht für Mann und Frau! Die internationale sozialistische Frauenbewegung zu Beginn des 20. Jahrhunderts und der Kampf um das Frauenwahlrecht. Bonn.

Otto, Louise, (1848) 2008: Adresse eines Mädchens. In: Gerhard, Ute/Pommerenke, Petra/Wischermann, Ulla (Hg.): Klassikerinnen feministischer Theorie. Grundlagentexte. Band I (17891919). Königstein/Taunus, 71-73.

Phillips, Anne, 1998: Democracy and Representation. Or, Why Should it Matter Who our Representatives Are?. In: Phillips, Anne (Hg.): Feminism and Politics. Oxford, New York, 224-240.

Pitkin, Hanna Fenichel, 1967: The Concept of Representation. Berkley, Los Angeles.

Richebächer, Sabine, 1982: Uns fehlt nur eine Kleinigkeit. Deutsche proletarische Frauenbewegung 1890-1914. Frankfurt/M.

Sapiro, Virginia, (1981) 1998: When are Interest Interesting? The Problem of Political Representation of Women. In: Phillips, Anne (Hg.): Feminism and Politics. Oxford, New York, 161-192.

Sauer, Birgit, 2011: Only paradoxes to offer? Feministische Demokratie- und Repräsentationstheorie in der Postdemokratie. In: Österreichische Zeitschrift für Politikwissenschaft. 40 (2), 125138.

Schaser, Angelika, 2009: Zur Einführung des Frauenwahlrechts vor 90 Jahren am 12. November 1918. In: Feministische Studien. 27 (1), 97-110.

Schindler, Paula, 1913: Frauenstimmrecht und Demokratie. Eine demokratische Stimme aus der Deutschen Vereinigung. In: Zeitschrift für Frauenstimmrecht. 15. Juni 1913, 35-36.

Schüller, Elke, 2005: Marie Stritt. Eine kampffrohe Streiterin in der Frauenbewegung (18551928). Königstein/Taunus.

Schwimmer, Rosita, 1907: Sozialdemokratie und Frauenstimmrecht. In: Ethische Kultur. 15 (20), 153-155.

Solltmann, Idamarie, 1917: Frauenstimmrecht und dauernder Friede. 1. u. 15. Juni 1917, $21-22$.

Steyerl, Hito/Gutiérrez Rodriguez, Encarnación, 2013: Einleitung. In: Steyerl, Hito/Gutiérrez Rodriguez, Encarnación (Hg.): Spricht die Subalterne deutsch? Migration und postkoloniale Kritik. Münster, 7-16.

Wängnerud, Lena, 2009: Women in Parliaments. Descriptive and Substantive Representation. In: Annual Review of Political Science. 12 (1), 51-69.

Welskoop, Thomas, 2000: Das Banner der Brüderlichkeit. Die deutsche Sozialdemokratie vom Vormärz bis zum Sozialistengesetz. Bonn.

Wolff, Kerstin, 2018: Noch einmal von vorn und neu erzählt. Die Geschichte des Kampfes um das Frauenwahlrecht in Deutschland. In: Richter, Hedwig/Wolff, Kerstin (Hg.): Frauenwahlrecht. Demokratisierung der Demokratie in Deutschland und Europa. Hamburg, 35-56.

Young, Iris Marion, 1993: Das politische Gemeinwesen und die Gruppendifferenz. Eine Kritik am Ideal des universalen Staatsbürgerstatus. In: Nagl-Docekal, Herta/Pauer-Studer, Herlinde (Hg.): Jenseits der Geschlechtermoral. Beiträge zur feministischen Ethik. Frankfurt/M., 267-304.

Young, Iris Marion, 2000: Inclusion and Democracy. Oxford.

Zetkin, Clara, 1907: Zur Frage des Frauenwahlrechts. Bearbeitet nach dem Referat auf der Konferenz sozialistischer Frauen zu Mannheim. Berlin. 


\section{Relationale Demokratie. Das verfassungsrechtliche Demokratieprinzip und gerechte Staatlichkeit in Deutschland ${ }^{1}$}

\section{CARA RÖHNER}

Nach 100 Jahren Frauenwahlrecht sind in keinem deutschen Parlament Frauen hälftig oder in der Mehrheit vertreten. Der Mandatsträgerinnenanteil stagniert bei etwa 25 bis 35\%. ${ }^{2}$ Auch die Bundestagswahl im Herbst 2017 hat zu keinerlei Fortschritt geführt, stattdessen sank der Anteil weiblicher Abgeordneter auf 30,7\%. ${ }^{3}$ Noch weniger Frauen sind in Regierungsämtern zu finden: Nur 10\% der Kommunen sind von Oberbürgermeisterinnen und 19\% der Länder von Ministerpräsidentinnen regiert (Kletzing/Lukoschat 2014, 6). Dies verweist auf eine anhaltende ungleiche Repräsentation der Geschlechter in legislativen und exekutiven Institutionen. Neben der geschlechterstereotypen Sozialisation, der weiblichen Doppelbelastung mit Haushalt, Kindern und Pflege sowie dem sozioökonomischen Status von Frauen (Kinzig 2007), gilt das sexistische Nominierungsverhalten von Parteien als die wesentliche Ursache für dieses Repräsentationsungleichgewicht (Holtkamp/Wiechmann/Eimer 2013; Davidson-Schmich 2016). Die Parteien rekrutieren in der parlamentarischen Demokratie das politische Personal und entscheiden damit über die geschlechtergerechte bzw. -ungerechte Aufstellung von Kandidat*innen.

Die Forschung hat neben dem Verhältniswahlrecht rechtsverbindliche Quoten als institutionelle Mechanismen für eine geschlechtergerechte Repräsentation identifiziert. So konnten beispielsweise Drude Dahlerup und Lenita Freidenvall (2009, 30f.) zeigen, dass Länder, die ein Verhältniswahlrecht anwenden, mit einem Mandatsträgerinnenanteil von durchschnittlich 19,6\% besser abschneiden als Länder mit einem Mehrheitswahlrecht mit durchschnittlich 10,5\%. Auch stellten sie fest, dass die Mehrheit der Länder mit einem Frauenanteil von über 30\% Quotenregelungen eingeführt hat. Quoten werden von Dahlerup und Freidenvall $(2005,29)$ daher auch als ,,fast track“ to equal representation“ beschrieben. Vor diesem Hintergrund wundert es nicht, dass Geschlechterquoten in über 100 Ländern existieren und über 15 Verfassungen zu finden sind. ${ }^{4}$

Die inklusiven Effekte von Quoten zeigen sich im deutschen Bundeswahlrecht. Hinsichtlich der verhältniswahlrechtlichen Wahllisten ist erkennbar, dass Wahlerfolge von Parteien, die sich selbst auf eine verbindliche Quote verpflichtet haben - Bündnis 90/Die Grünen (50\%), Die Linke (50\%), und die SPD $(40 \%)^{5}-$, regelmäßig zu einem ausgewogeneren Geschlechterverhältnis in den deutschen Parlamenten beitragen. Nach Louise Davidson-Schmich (2016, 220f.) haben diese Parteiquoten außerdem zu einer weiblichen Nachwuchsförderung geführt, sodass verstärkt weibliche Parteimitglieder für Kandidaturen angefragt werden (s. auch Davidson-Schmich in diesem Heft). 
Für die mehrheitswahlrechtlichen Direktmandate gibt es bisher keine Quotierung. Parteien stellen weiterhin deutlich weniger Frauen als Männer für Direktmandate auf und in der Konsequenz unterlaufen so eine hohe Anzahl gewonnener Direktmandate die positiven Effekte der jedenfalls teilweise quotierten Wahllisten (Ahrens u.a. 2018, 17f.). So erhielten Frauen bei der Bundestagswahl 2013 nur 20\% der 299 Direktmandate, aber 50\% der 332 Sitze, die über Wahllisten vergeben wurden (Der Bundeswahlleiter 2015, 90).

Die ungleichen Effekte der Direktmandate werden mit der Kandidat*innenzentriertheit des Mehrheitswahlrechts erklärt: Aufgrund stereotyper Geschlechterrollen, die politische Verantwortung und Öffentlichkeit maskulin codieren, bieten sich männliche Kandidaten zum einen vermehrt zur Wahl an und werden zum anderen von den Parteien als erfolgsversprechender wahrgenommen. Im deutschen Kontext gilt die Nominierung für ein Direktmandat zudem als Belohnung für ein langjähriges Parteiengagement, weshalb dies strukturell männliche Parteimitglieder bevorteilt, die typischerweise kaum reproduktive Arbeit leisten und daher über mehr Zeitressourcen verfügen (Holtkamp/Wiechmann/Eimer 2013, 11).

Wirft man hingegen einen Blick in die herrschende Literatur der deutschen Verfassungswissenschaft, dann fällt auf, dass weder das Repräsentationsungleichgewicht als demokratisches Defizit noch eine Reform des Wahlrechts oder die Einführung gesetzlicher Quoten als Inklusionsmechanismen diskutiert werden. In aktuellen Monografien, Handbüchern und in der für die Rechtswissenschaft wichtigen Kommentarliteratur ${ }^{6}$ wird die Unterrepräsentation von Frauen nicht zu den relevanten demokratischen Defiziten gezählt, sie bleibt schlicht unerwähnt (Steinberg 2013; Unger 2008; Wild 2003; Isensee/Kirchhof 2005; die Kommentierung zu Art. 20 und Art. 38 GG in Dreier 2015; Epping/Hillgruber 2017; Jarass/Pieroth 2016; Sachs 2014). Dieser Befund einer De-Thematisierung ungleicher Repräsentation, so meine These, folgt aus dem individualisierenden Demokratieverständnis des liberalen Repräsentationsmodells. Dieses begreift Staatsbürger*innen als freie und gleiche Rechtssubjekte unabhängig von ihrer sozialen Position und richtete sich historisch gegen die politische Unfreiheit der Feudalherrschaft. Eine solch abstrakt-formale Perspektive bietet jedoch keinen Maßstab für gerechte Staatlichkeit und hat dementsprechend kein Vokabular für die Thematisierung von Ungleichheitsachsen entwickelt. Dies führt dazu, dass in Rechtskonflikten feministische Konzepte fehlen und abstrakte - also von Ungleichheitsverhältnissen losgelöste - Interpretationen der Wahlrechtsgleichheit und Parteifreiheit dominieren. Daher existiert im juristischen Diskurs eine Konzeption des Demokratieprinzips, die die faire Repräsentation „der Anderen“ als Störung und Unfreiheit anstatt als demokratisches Prinzip erscheinen lässt.

Im Folgenden wird zuerst das individualisierende Demokratieverständnis der herrschenden Verfassungspraxis in Deutschland dargestellt. Anschließend werden relational-feministische Ansätze aus der Politikwissenschaft und Verfassungswissenschaft rezipiert, um eine relationale Interpretation des Demokratieprinzips zu entwickeln. Diese macht, so der nächste Abschnitt, gesellschaftliche Ungleichheitsverhältnisse 
zum Maßstab des Verfassungsrechts und versteht institutionelle Inklusionsmechanismen als Verwirklichung des Demokratieprinzips. Damit verschiebt eine relationale Perspektive den methodischen Fokus vom abstrakten Subjekt auf die Strukturierung von gesellschaftlichen Beziehungen. Sie ermöglicht eine Rechtssprache, die Ungleichheit als relationales Phänomen im Recht adressierbar macht und im Ergebnis eine diese transformierende Rechtsinterpretation anstrebt (Nedelsky 2013).

\section{Individualisierende Demokratie}

Das Grundgesetz (GG) schweigt zu gleicher Repräsentation. Art. 20 Abs. 1, Abs. 2 GG und Art. 38 Abs. 1 GG begründen die Herrschaftsform der repräsentativen Demokratie und fordern eine unmittelbare, freie, gleiche und geheime Wahl. Art. 21 GG spricht den Parteien die zentrale Funktion in der parlamentarischen Demokratie zu, Bindeglied zwischen gesellschaftlicher Selbstorganisation und staatlichpolitischen Institutionen zu sein. Die Konkretisierung des Wahlprozesses bleibt der Bundesgesetzgebung überlassen.

In der Verfassungsrechtsprechung und der Kommentarliteratur dominieren ein unitärer Volksbegriff, eine formale Wahlrechtsgleichheit sowie eine abstrakte Freiheit der Wahl, welche die Forderung nach fairer Repräsentation mittels institutioneller Inklusionsmechanismen systemfremd erscheinen lassen.

\section{Unitäres Volk}

Nach Art. 38 Abs. 1 S. 2 GG vertreten Abgeordnete das gesamte Volk, sind an Aufträge und Weisungen nicht gebunden und nur ihrem Gewissen unterworfen. Abgeordnete verfügen im Verhältnis zur Wähler*innenschaft also über ein freies Mandat. Sie gelten nicht als Vertreter*innen bestimmter Kollektive oder Interessensgruppen, sondern sind nur dem Allgemeininteresse verpflichtet. Damit geht die Idee einher, dass die Abgeordneten ein ergründbares Gesamtinteresse aller Staatsbürger*innen vertreten können und die Gesamtheit der Abgeordneten eine Gesamtrepräsentation des Volkes erreicht (z.B. BVerfGE 112, 118 (134) - 2004; BVerfGE 134, 141 (172) - 2013). ${ }^{7}$ Das Bundesverfassungsgericht fasst den Zusammenhang zwischen Volkssouveränität und dem Status der Abgeordneten z.B. wie folgt zusammen:

Der Deutsche Bundestag ist das unmittelbare Repräsentationsorgan des Volkes. Er besteht aus den als Vertretern des ganzen Volkes gewählten Abgeordneten, die insgesamt die Volksvertretung bilden. Der durch Art. 38 Abs. 1 Satz 2 GG gewährleistete repräsentative Status der Abgeordneten (...) ist Grundlage für die repräsentative Stellung des Bundestages, der als „,besonderes Organ“ (Art. 20 Abs. 2 GG) die vom Volk ausgehende Staatsgewalt ausübt (...). (BVerfGE 130, 318 (342) - 2011)

Das Volk bleibt in dieser Konzeption eine abstrakte Masse, die nicht wesentlich durch Ungleichheitsverhältnisse bestimmt ist, weshalb es auch nicht auf die indi- 
viduelle Verortung der Repräsentant*innen ankommt. So gewährleistet das Demokratieprinzip zwar seit der Einführung des Frauenwahlrechts im November 1918 die formale Gleichheit aller Staatsbürger*innen, erfasst aber nicht, dass in der Realität tatsächlich überwiegend weiße, nicht-behinderte, heterosexuelle Männer aus der Mittelschicht die parlamentarischen Prozesse bestimmen. In einem unitären Volks- und Demokratieverständnis gilt dies verfassungsrechtlich jedoch nicht als problematisch, weil es zu keinem Repräsentationsdefizit kommen könne, wenn die durch eine demokratische Wahl gewählten Abgeordneten das gesamte Volk vertreten (Foljanty 2006, 194f.).

\section{Formale Wahlrechtsgleichheit}

In einer formal konzipierten Wahlrechtsgleichheit sieht das Bundesverfassungsgericht die demokratische Gleichheit aller Staatsbürger*innen als Basis der staatlichen Ordnung begründet:

Für eine freiheitlich-demokratische Grundordnung, wie das Grundgesetz sie geschaffen hat, ist die Gleichbewertung aller Staatsbürger bei der Ausübung des Wahlrechts eine der wesentlichen Grundlagen der Staatsordnung. (BVerfGE 6, 84 (91) - 1957; BVerfGE 131, $316(334)-2012)$

Für das Wahlrecht bedeutet dies, dass jede abgegebene Stimme gleich viel zählt (gleicher Zählwert) und sich gleich stark im Wahlergebnis widerspiegelt (gleicher Erfolgswert). Die Gleichheit der Stimme ist hier das zentrale demokratische Prinzip. Historisch richtet sich dieses gegen jegliche Formen des Zensus- oder Pluralwahlrechts. Vor diesem Hintergrund wird die Wahlrechtsgleichheit heute als striktes Differenzierungsverbot verstanden (z.B. BVerfGE 121, 266 (295) - 2008; BVerfGE 135, 259 (284) - 2014), das eine ungleiche Gewichtung der Stimmen, die Benachteiligung von einzelnen Parteien sowie eine Ungleichbehandlung der Wähler*innen oder Kandidat*innen aufgrund von Zugehörigkeiten verbietet. Gesetzliche Differenzierungen sind daher nur ausnahmsweise im Fall von „zwingenden Gründen“ oder kollidierendem Verfassungsrecht zulässig. Mit diesem Maßstab wurden beispielsweise die 5\%-Klausel zur Gewährleistung einer funktionsfähigen Volksvertretung für verfassungskonform (BVerfGE 51, 222 - 1979) und der Effekt des negativen Stimmgewichts für verfassungswidrig (BVerfGE 121, 266 - 2008) erklärt. Ob zu den zwingenden bzw. den durch die Verfassung legitimierten Gründen, die der Wahlrechtsgleichheit die Waage halten können (BVerfGE 135, 259 (286) - 2014), auch das Gleichberechtigungsgebot gemäß Art. 3 Abs. 2 GG zählt, nach dem der Staat die tatsächliche Durchsetzung der Gleichberechtigung fördern und auf die Beseitigung von Nachteilen hinwirken muss, hat das Bundesverfassungsgericht bisher nicht zu entscheiden gehabt. Schaut man sich allerdings die Literatur an, dann scheint sich das Gleichberechtigungsgebot nicht auf den politisch-staatlichen Bereich zu erstrecken bzw. der formalen Wahlrechtsgleichheit nicht die Waage halten zu können. 
So argumentiert beispielsweise Johann Hahlen in seiner Kommentierung des $\S 27$ Bundeswahlgesetz:

Im Hinblick auf die strenge Formalisierung der Wahlrechtsprinzipien ist für die Berücksichtigung objektiver Wertentscheidungen zugunsten der Frauenförderung kein Platz. (...) Faktisch gegebene zahlenmäßige Ungleichheiten sind grundsätzlich keine rechtlich relevante Benachteiligung von Frauen i.S. des Art. 3 Abs. 2 und Abs. 3 GG, die eine Differenzierung gegenüber der strengen Wahlrechtsgleichheit rechtfertigen können. (...) Denn eine gesetzlich verbindliche Frauenquote wäre eine die Wahlrechtsgleichheit der männlichen Bewerber verletzende, weil unangemessene Diskriminierung. (§ 27 BWahlG in Schreiber 2013, Rn. 14) $)^{8}$

Und ebenso kommt Jörn Ipsen in der Kommentierung des Parteiengesetzes zu dem Ergebnis, dass eine Rechtfertigung über das Gleichberechtigungsgebot nicht in Betracht komme, da es sich seiner Ansicht nach nur um ein Staatsziel und keinen Wahlrechtsgrundsatz handele und „Parität um ihrer selbst willen“ kein legitimes Verfassungsziel sei (§ 17 PartG in Ipsen 2008, Rn. 17ff., Zitat Rn. 24).

Das formale Verständnis der Wahlrechtsgleichheit führt in diesem Kontext zu einer verfassungsrechtlichen Differenzierung zwischen parteiinternen und gesetzlichen Quotenregelungen. Die Selbstverpflichtung der Parteien auf bestimmte Quoten wird in der Literatur zwar als Beeinträchtigung der passiven Wahlrechtsgleichheit männlicher Parteimitglieder angesehen, sie könne aber durch die Parteifreiheit gerechtfertigt werden (siehe die Kommentierungen zu Art. 38 in Dreier 2015, Rn. 107; von Mangoldt/Klein/Strack 2010, Rn. 125 (Fn. 240), 144ff.; Maunz/Dürig 2017, Rn. 108; und zu § 15 PartG Kersten/Rixen 2009, Rn. 27ff.). Dieser herrschenden Ansicht hat sich die Dritte Kammer des Zweiten Senats des Bundesverfassungsgerichts angeschlossen, als sie über eine Verfassungsbeschwerde wegen Versagung von Prozesskostenhilfe und in diesem Zuge mittelbar über die Zulässigkeit parteiinterner Frauenquoten zu entscheiden hatte. Sie stellt in wenigen Sätzen fest, dass Geschlechterquoten zwar aufgrund der Wahlgrundsätze, die auch für die demokratische Organisation von Parteien bindend sind, als Beeinträchtigung der passiven Wahlrechtsgleichheit rechtfertigungsbedürftig sind, dass diese aber durch die Parteifreiheit gerechtfertigt werden können, weil es den Parteien frei steht, ihre Organisation programmatischen Zielen entsprechend auszugestalten (Beschluss v. 1.4.2015, 2 BvR 3058/14, Rn. 25).

Eine solche Rechtfertigung gelingt nach der Literatur bei gesetzlichen Quotenvorgaben allerdings nicht mehr, weil diese als unverhältnismäßiger Eingriff in die Freiheit der Partei und somit als undemokratisch bewertet werden (Jutzi 2012). Eine solche Begründung erinnert nicht nur an Versuche, Gleichheitsansprüche von Frauen und Minderheiten im Namen gesellschaftlicher Selbstorganisation als Eingriff in die private Sphäre abzuwehren, sondern lässt außerdem unreflektiert, dass unterschiedliche Perspektiven zu unterschiedlichen Antworten führen (Baer/Markard zu Art. 3 Abs. 2, 3 GG in: von Mangoldt/Klein/Starck 2018, Rn. 422; Gaßner/Neusüß/ Viezens 2012; Williams 2009). 


\section{Freiheit der Wahl}

Das Repräsentationsungleichgewicht wurde erstmals vor dem Verfassungsgerichtshof Rheinland-Pfalz verhandelt. ${ }^{9}$ Dieser hatte über die Reform des Kommunalwahlrechts vom Jahr 2013 zu entscheiden. Da der Frauenanteil in den rheinland-pfälzischen Gemeindevertretungen nur 16,8\% betrug, entschied sich die SPD geführte Landesregierung für eine Wahlrechtsreform, die allerdings nicht auf gesetzliche Quoten, sondern auf weichere, rein informatorische Mechanismen setzte: Auf die Wahlzettel sollten zukünftig das Gleichberechtigungsgebot gem. Art. 3 Abs. 2 GG, der Frauenanteil in der jeweiligen Kommunalvertretung zwei Monate vor der Wahl, das Geschlecht der Kandidat*innen sowie der Frauenanteil der aussichtsreichsten Plätze jeder Wahlliste abgedruckt werden (GVB1. 2013, 139). ${ }^{10}$

Der Verfassungsgerichtshof sah in diesen geschlechtsspezifischen Angaben einen Verstoß gegen die Freiheit der Wahl, da diese ,unbedingten Schutz“ vor einer staatlichen Einflussnahme während des Wahlaktes garantiere (Beschluss v. 13.6.2014, VGH N 14/14, VGH B 16/14). Seine Entscheidung begründet der Verfassungsgerichtshof mit dem freien Subjekt als Quelle der demokratischen Ordnung: Beim Wahlakt als „Grundakt demokratischer Legitimation“ handele es sich um den „Kulminationspunkt der Phase der Willensbildung des Volkes“ sowie um die ,Willensbetätigung jedes einzelnen Bürgers als Ursprung der Staatsgewalt in der Demokratie“ (Rn. 55):

Vor diesem Hintergrund kann eine inhaltliche Einwirkung auf das Ergebnis der Entscheidung des Wählers im Zeitpunkt des Wahlaktes und in der Privatheit der Wahlkabine durch eine Gestaltung des Stimmzettels auch nicht damit gerechtfertigt werden, dass sie sonstigen, materiellen Verfassungswerten - etwa Gleichheits- und Freiheitsrechten oder Staatszielbestimmungen (=Gleichberechtigung der Geschlechter, CR) - diene. (Rn. 57)

Damit greift der Verfassungsgerichtshof abstrahierende und individualisierende Argumentationsmuster auf, die auf die demokratische Gleichheit der Staatsbürger*innen in Abgrenzung zur ständischen Herrschaftsform verweisen. Er verkennt damit allerdings, dass sich der gesellschaftlich-historische Kontext inzwischen gewandelt hat und für ,neue“ Legitimationsfragen alte Argumentationsmuster nur begrenzt weiterführend sind. So kommt es dazu, dass, obwohl die Kommunalwahlrechtsreform augenfällig auf die faire Repräsentation von Frauen zielte, der Verfassungsgerichtshof die Legitimationsfrage der geschlechtergerechten Demokratie vollständig ausblendet und die anhaltende massive Unterrepräsentation weiblicher Subjekte mit keinem Wort erörtert. Ebenso wenig setzt er sich mit dem verfassungsrechtlichen Gleichberechtigungsgebot auseinander, das als Verfassungsnorm über die gleiche Bedeutung wie die Wahlfreiheit verfügt.

Stattdessen definiert der Verfassungsgerichtshof die Geschlechterangaben auf dem Wahlzettel als „Störung“ der privaten Situation der Stimmabgabe, ,in der sich der individuelle politische Wille des einzelnen Wählers ungestört entfalten“ können 
soll (Rn. 56). Die freie demokratische Entscheidung werde infrage gestellt, weil an Wähler*innen appelliert werde, bevorzugt Kandidat*innen des unterrepräsentierten Geschlechts zu wählen. Dass ein Mandatsträgerinnenanteil von 16,8\% möglicherweise eine „Störung“ eines Rechts auf effektive Repräsentation oder die Institution der repräsentativen Demokratie darstellen könnte, thematisiert der Verfassungsgerichtshof demgegenüber nicht. Er bestimmt die Freiheit der Wahl als Voraussetzung einer „funktionsfähigen Demokratie“ (Rn. 41), eine geschlechtergerechte Repräsentation in kommunalen Vertretungskörperschaften hingegen nicht.

Wie die Entscheidungsbegründung des Verfassungsgerichtshofs zeigt, fehlt es dem Verfassungsrecht offensichtlich an einem Interpretationsrepertoire, das eine nichtindividualisierende Perspektive auf Demokratie eröffnet und hilft, die strukturelle Verschränkung von staatlich-männlicher Überrepräsentation und gesellschaftlich ungleichen Geschlechterbeziehungen zu verstehen. Diese De-Thematisierung ist unabhängig vom rechtlichen Ergebnis - zu kritisieren, weil auch negativ ausfallende Urteile Anknüpfungspunkte für die zukünftige Spruchpraxis bilden.

\section{Perspektiven relationaler Demokratie}

Feministische Autorinnen verfolgen eine relationale Perspektive auf Demokratie und Bürgerschaft. Sie weisen die Präsenz historisch ausgeschlossener Subjekte (Phillips 2004), eine paritätische Repräsentation zur Überwindung des Geschlechtervertrags (Rodríguez-Ruiz/Rubio-Marín 2012) sowie die effektive Repräsentation von Bürgerinnen (Laskowski 2014) als demokratische Prinzipien aus. Damit bieten sie ein Interpretationsrepertoire für eine relationale Konzeption des verfassungsrechtlichen Demokratieprinzips in Art. 20 Abs. 2 GG. Eine solche ist nicht auf das abstrakte Subjekt, sondern auf die Transformation ungerechter Geschlechterbeziehungen zur Schaffung gerechter Staatlichkeit gerichtet.

\section{Politik der Präsenz}

Problematisch an der gegenwärtigen liberalen Demokratiekonzeption ist nach Anne Phillips (2004) die Idee der Differenz als rein intellektuelle Heterogenität, sodass es primär um die Frage gehe, was repräsentiert werde und nicht wer repräsentiere. Sie geht davon aus, dass dieser Fokus auf Meinungsvielfalt unzulänglich für politische Inklusion sei. Denn durch diese Konzeption von Differenz als intellektuelle Heterogenität spiele es keine Rolle, wer diese verschiedenen Ansichten repräsentiere. Werde Differenz jedoch als Differenz von Identitäten, Erfahrungen oder sozialen Gruppen gefasst, erscheine es nicht mehr so einfach möglich, die Frage nach dem wer auszublenden: „Men may conceivably stand in for women when what is at issue is the representation of agreed policies or programs or ideals. But how can men legitimately stand in for women when what is at issue is the representation of women per se?" (ebd., 6). 
Phillips Zugang wirft die Frage nach einer nicht-essentialisierenden Subjektkonzeption auf. Sie will einerseits nicht annehmen, dass es „die Erfahrungen“ von Frauen oder Minderheiten gäbe, andererseits gesteht sie ein, dass man einen wie auch immer potentiell geteilten Erfahrungshorizont voraussetzen müsse, da es ansonsten keinen Unterschied mache, wer in staatlichen Organen anwesend sei und die Forderung nach mehr Frauen oder mehr Angehörigen von Minderheiten in der Politik leerlaufe. Sie verfolgt daher einen schwachen Gruppenbegriff, der nicht von authentischen Gruppenerfahrungen oder einheitlichen Willen ausgeht, sondern darauf abstellt, dass es bestimmte Erfahrungen gibt, die überwiegend und typischerweise von einer spezifischen gesellschaftlichen Gruppe gemacht werden. Vergeschlechtlichte Erfahrungen sieht sie dementsprechend in einer männlich geprägten Legislative als unzureichend adressiert an, weshalb das Frauenwahlrecht alleine nicht für eine faire Repräsentation ausreiche: „Equal right to vote have not proved strong enough to deal with this problem; there must also be equality among those elected to office." (ebd., 66).

Die verstärkte Präsenz ,der Anderen“ in repräsentativen Organen sei als symbolische Repräsentation erforderlich, um Infantilisierungen von Frauen und Minderheiten durch monosexuelle/monokulturelle Entscheidungsorgane $\mathrm{zu}$ vermeiden, zuvor Ausgeschlossene als gleichwertige und gleichfähige Subjekte anzuerkennen und damit asymmetrische Machtbeziehungen in Frage zu stellen. Zudem könne dies politische Entscheidungsprozesse verändern, da bisher vernachlässigte Themen auf die politische Agenda gesetzt und die Norm dessen, was politisch wichtig ist, verschoben werden könne (ebd., 39ff.).

Für die Bestimmung der relevanten Ungleichheitsachsen, die in Parlamenten repräsentiert sein sollten, argumentiert Phillips gegen den Versuch, alle denkbaren gesellschaftlichen Gruppen in Parlamenten abbilden zu wollen. Stattdessen plädiert sie für diejenigen Gruppen, die historisch besonders unterdrückt und aus politischen Repräsentationsstrukturen ausgeschlossen waren. Anstatt also abstrakt ein Spiegelbild der Gesellschaft zu fordern, kommt es auf konkrete Exklusionserfahrungen an. In den USA sind dies für sie insbesondere Frauen und die schwarze Bevölkerung, weil diese durch soziale Bewegungen immer um ihre politische Inklusion gekämpft haben.

Phillips Politik der Präsenz zielt allein auf die Sicherstellung der Präsenz „der Anderen" durch institutionelle Inklusionsmechanismen (ebd., Kapitel 3), sie geht aber nicht davon aus, dass sich diese auch notwendigerweise in eine Politik für die Anderen übersetzen wird. Dennoch sei allein - und das ist ihre Pointe - deren Präsenz ein demokratisches Prinzip:

Including those previously excluded matters even if it proves to have no discernible consequences for the policies that may be adopted. Part of the purpose, that is, is simply to achieve the necessary inclusion: to reverse previous histories of exclusion and the way these constituted certain kinds of people as less suited to govern the rest. (ebd., 40) 


\section{Paritätische Demokratie}

Der Fokus der Politik der Präsenz auf historische Kämpfe kann mit Blanca Rodríguez-Ruiz und Ruth Rubio-Marín (2012) für das Geschlechterverhältnis konkretisiert werden. Sie argumentieren, dass repräsentative Demokratie gegenwärtig verfassungsrechtlich nichts Anderes als paritätische Demokratie bedeuten könne (parity democracy model). Mit dieser Argumentation wollen sie eine gesetzliche Verpflichtung der Parteien, zur Hälfte Frauen zu nominieren, als Ausdruck des Demokratieprinzips konzipieren.

Diese These leiten sie aus einer Kritik der liberal-demokratischen Staatlichkeit und des autonomen Subjekts her. Auf Carol Patemans (1988) Ausführung zum sexual contract zurückgreifend, nach dem liberale Ordnungen nicht nur auf einem Gesellschaftsvertrag, sondern auch auf einem Geschlechtervertrag gründen, kritisieren sie die geschlechtlich kodierte Trennung von privater und öffentlicher Sphäre als Strukturmoment des modernen Staates und die Identifikation von Subjektivität und Bürgerschaft mit Unabhängigkeit:

As a foundational myth of the state, the social-sexual contract thus constructs the public sphere as a space for the interaction of citizens, conceptualized as independent individuals as males. It pushes dependency, and women, beyond the state's area of concerns. (...) Democracy, citizenship, and representation are constructed, in brief, as the field of independence. It is independence, conceptualized as male, which representative democracy was supposed to represent. (Rodríguez-Ruiz/Rubio-Marín 2012, 200)

Paritätische Demokratie solle helfen, Bürger*innenschaft, Demokratie und Repräsentation als interdependente Phänomene zu denken. Dafür müsse Abhängigkeit als relevantes (und feminin codiertes) Moment menschlichen Lebens stärker in das Politische geholt und damit Autonomie nicht länger als Unabhängigkeit, sondern als Interdependenz gedacht werden:

Dependence and its management, caring and being cared for, thus find a dignified space within the public sphere, not as deviations from, but as defining elements of the ideal of the individual and the citizen. (Inter)dependency and care become constituent components of citizenship. (ebd., 201)

Rodríguez-Ruiz und Rubio-Marín argumentieren also, dass der Ausschluss des Weiblichen historisch konstitutiv für moderne Staatlichkeit und repräsentative Demokratie ist und diese genau deswegen nun geschlechtergerecht re-definiert werden müssen. Wie Phillips argumentieren sie also nicht pauschal für ein gruppenpluralistisches Repräsentationsmodell, sondern für die Inklusion der historisch exkludierten Gruppe der Frauen. ${ }^{11}$

Indem Rodríguez-Ruiz und Rubio-Marín moderne Staatlichkeit über die Trennung der öffentlichen von der privaten Sphäre als historisch mit Geschlechterungleichheit verstrickt thematisieren, gelingt ihnen die systematische Verknüpfung von Staat- 
lichkeit, demokratischer Repräsentation und Geschlechterverhältnissen. Damit machen sie die ungleiche Präsenz der Geschlechter zur Frage gerechter Staatlichkeit und können gesetzliche Quotenregelungen als verfassungsrechtlich erforderlichen Transformationsmechanismus des ungleichen Geschlechtervertrags konzipieren.

\section{Effektive Repräsentation}

Im angelsächsischen Kontext wird faire Repräsentation darüber hinaus anhand des individuellen Wahlrechts diskutiert. Zum individuellen Wahlrecht gehöre auch das Recht auf effektive Repräsentation, also die Möglichkeit der Wahlberechtigten, aus ihrer Gruppe eine angemessene Anzahl von Vertreter*innen zu wählen. So argumentiert z.B. Kathleen L. Barber (2000, xii): „the right to vote is the right to cast an effective vote, and implied in "effective" is the right to representation." In diesem Sinne hat auch der Supreme Court of Canada das Wahlrecht aus Section 3 der Canadian Charta of Rights and Freedoms interpretiert, als es um die Vertretung von Stadt- und Landbevölkerung im Zuge der Neubestimmung von Wahlkreisgrenzen ging. Das Gericht hat nicht auf das Prinzip des gleichen numerischen Einflusses der Wahlstimme (equal representation), sondern auf die Gewährleistung eines fairen Repräsentationsergebnisses (effective representation) abgestellt. Denn das Wahlrecht sei nicht nur auf die numerische Formel „one person, one vote“ $\mathrm{zu}$ bringen, vielmehr seien auch andere Faktoren für dessen Interpretation wichtig „,so that different interests, classes and localities should be fairly represented, that the principle of numbers should not be the only one." (Supreme Court of Canada, Urteil vom 6.6.1991, Nr. 22345, Reference re Provincial Electoral Boundaries (Saskatchewan)).

Im deutschen Diskurs hat Silke Ruth Laskowski (2014) in ähnlicher Weise für eine effektive Repräsentation und daran anschließend für die Einführung eines paritätischen Wahlgesetzes nach französischem Vorbild argumentiert. Dafür greift sie die bisherige Rechtsprechung des Bundesverfassungsgerichts zur effektiven Einflussnahme als Moment des Demokratieprinzips auf. Nach dieser bedeute effektive Einflussnahme die Rückbindung der Staatsgewalt an den demokratischen Volkswillen (z.B. BVerfGE 93, 37 (66) - 1995), daher könne demokratische Legitimation nur bei effektiver Einflussnahme erzeugt werden. Weil aber das deutsche Wahlrecht nicht die gleiche demokratische Teilhabe und mithin die gleiche effektive Einflussnahme von Bürgerinnen sicherstelle, bestünde ein demokratisches Legitimationsdefizit (Laskowski 2014, 97ff.). Für sie genügt es daher nicht, weibliche Subjekte über das formale Wahlrecht politisch zu inkludieren, vielmehr muss ein faires Repräsentationsergebnis gewährleistet sein. Volkssouveränität konzipiert als gleiche effektive Einflussnahme könne daher nur paritätische Repräsentation bedeuten.

Laskowski verankert ihre Argumentation dabei nicht wie der kanadische Supreme Court in einem materialen individuellen Wahlrecht, sondern im Prinzip der repräsentativen Demokratie selbst sowie im Gleichberechtigungsgebot: „Ein paritätisches 
Wahlrecht gestaltet daher nicht nur das Demokratiegebot aus, sondern erfüllt gleichzeitig auch den Verfassungsauftrag aus Art. 3 Abs. 2 GG (...).“(ebd., 99).

\section{Fazit: Eine relationale Interpretation des Demokratieprinzips}

Mit einer relationalen Konzeption des Demokratieprinzips kann ein verfassungsrechtlicher Maßstab für gerechte Staatlichkeit entwickelt werden, der eine geschlechtergerechte Ämtervergabe als Voraussetzung für eine demokratische Ordnung definiert. Damit steht ein verfassungsrechtliches Interpretationsrepertoire zur Verfügung, um die bisher unangetastete Parteifreiheit geschlechtergerecht zu interpretieren und die Parteien gesetzlich zu einer geschlechtergerechten Nominierung zu verpflichten.

Dieses Argument ist nicht auf den legislativen Bereich beschränkt, weil Parteien in der parlamentarischen Demokratie als Gatekeeper für alle wichtigen staatlichen Positionen fungieren: Von der Nominierung von Bundespräsident*innen, Bundeskanzler*in und Ministerpräsident*innen der Länder über die Ernennung der Landes- und Bundesminister*innen bis hin zur Wahl der Richter*innen des Bundesverfassungsgerichts werden alle wichtigen exekutiven und judikativen Ämter von der jeweils dominierenden Partei bestimmt. Relationale Demokratie als Basis gerechter Staatlichkeit kann in der parlamentarischen Demokratie daher auch für die Exekutive und Judikative fruchtbar gemacht werden.

Für die Entwicklung einer relationalen Interpretation des Demokratieprinzips kann auf die drei skizzierten Ansätze zurückgegriffen werden. Kern dieser Ansätze ist die Transformation der strukturell asymmetrischen Geschlechterbeziehungen als Grundlage einer gerechten staatlichen Ordnung. In diesem Sinne hat Phillips (2004) für eine Politik der Präsenz argumentiert, mit der sie die Anwesenheit heterogener Repräsentant*innen als ein demokratisches Prinzip ausweist ohne dabei das Subjekt der „Frauen“ zu essentialisieren. Sie geht dafür von einem schwachen Gruppenbegriff anhand eines potentiell geteilten Erfahrungswissens sowie von historisch umkämpften Ausschlüssen aus. Das Moment der Präsenz kann mit Rodriguez-Ruíz und Rubio-Marín (2012) als eines der paritätischen Präsenz konkretisiert werden. Sie zeigen auf, dass moderne Verfassungsstaatlichkeit, Demokratie und selbstbestimmte Bürgerschaft konstitutiv mit dem Ausschluss des Weiblichen verbunden sind und das Demokratieprinzip heute daher notwendigerweise nur die paritätische Präsenz von weiblichen und männlichen Subjekten in repräsentativen Organen bedeuten kann, um die historische Exklusion zu überwinden. Inklusionsmechanismen, die dies gewährleisten, insbesondere verbindliche Quoten, sind dementsprechend als Ausdruck und nicht als Beeinträchtigung des verfassungsrechtlichen Demokratieprinzips anzusehen. Laskoswki (2014) zeigt schließlich, dass eine relationale Konzeption an die Spruchpraxis des Bundesverfassungsgerichts zur effektiven Einflussnahme anschließen kann, nach der das Volk Einfluss auf die Staatsgewalt ausüben können muss. Für die Einflussnahme von Bürgerinnen reicht das formale Wahlrecht jedoch 
nicht aus; stattdessen ist zur Gewährleistung einer effektiven Repräsentation eine paritätische Repräsentation Voraussetzung.

In der Konsequenz führt ein solch relationales Verständnis zu einer Neubewertung gesetzlicher Quoten im Wahlrecht. Die derzeit herrschende Ansicht verfolgt eine individualisierende Perspektive, nach der die Wahlrechtsgleichheit davor schützt, allein aufgrund des Geschlechts nicht als Kandidat*in aufgestellt zu werden (formale Gleichheit). Demokratie wird hierbei unabhängig von gerechten Geschlechterbeziehungen gedacht und die anhaltende Überrepräsentation männlicher Subjekte als keine relevante Beeinträchtigung des Demokratieprinzips qualifiziert.

Wird hingegen ein relationaler Maßstab angelegt, dann ist die Wahlrechtsgleichheit darauf gerichtet, gleiche demokratische Teilhabe für historisch ausgeschlossene Gruppen zu gewährleisten, darauf beruhende Privilegien abzubauen und inklusive Repräsentationsstrukturen zu schaffen (materiale Gleichheit). Die strukturelle Diskriminierung von Frauen, die sich in der ungleichen Repräsentation manifestiert, wird folglich nicht mit der Beeinträchtigung, die männliche Kandidaten durch Quoten erfahren würden, gleichgesetzt. Stattdessen werden Quotenregelungen in einer relationalen Interpretation des Demokratieprinzips als Voraussetzung einer demokratischen Ordnung konzipiert.

Eine solche paritätische Quotierung wäre sicherlich nicht der Weisheit letzter Schluss und ist insbesondere keine abschließende Antwort auf die demokratische Repräsentation vielfältiger Subjektivitäten, z.B. jenseits der Geschlechterbinarität. Gegenwärtig sind sie aus demokratietheoretischer Sicht dennoch notwendig, um die herrschenden Verhältnisse in den staatlichen Institutionen und den juristischen Diskurs in Bewegung zu bringen.

\section{Anmerkungen}

1 Der Beitrag basiert auf meiner bisher unveröffentlichten Dissertation „Ungleichheit und Verfassung. Vorschlag für eine relationale Rechtsanalyse“, Februar 2018, Universität Frankfurt/M.

2 Nur Brandenburg und Thüringen erreichen derzeit einen Anteil von circa 40\%.

3 Damit ist Deutschland von Platz 23 auf Platz 46 der World-Classification-List der Inter-Parliamentary-Union abgestiegen, die alle sechs Monate ein weltweites Ranking zum Frauenanteil in Parlamenten veröffentlicht (www.ipu.org).

4 Vgl. Global Database of Quotas for Women, www.quotaproject.org.

5 Die CDU bzw. CSU haben ein unverbindliches Quorum von 33\%, bzw. 40\% für Parteifunktionen, die FDP und AfD gar keine Regelung. Im 19. Deutschen Bundestag liegt der Männeranteil bei der AfD bei $90 \%$, bei der CDU/CSU bei $80 \%$, bei der FDP bei $79 \%$, bei der SPD bei $58 \%$, Die Linke bei $47 \%$ und Bündnis 90/Die Grünen bei $42 \%$.

6 In dieserwerden der Stand der Rechtsprechung und die „,herrschende Meinung“ zu einzelnen Rechtsnormen zusammengefasst, weshalb sie für die Praxis einflussreiche Nachschlagewerke sind.

7 Im Folgenden wird eine rechtswissenschaftliche Zitierweise für die Verweise auf Rechtsprechung verwendet. Das Kürzel BVerfGE steht für Entscheidungen des Bundesverfassungsgerichts, herausgegeben von Mitgliedern des Bundesverfassungsgerichts, Tübingen. Die Ziffern stehen für Band, Seite des Urteils (Seite der Fundstelle) und Jahr der Entscheidung; verfügbar unter: www.servat.unibe.ch. 
8 Kommentare und Urteile (sofern für Urteile nicht eine Entscheidungssammlung als Quelle herangezogen wird) werden in Absätze gegliedert und nach Randnummern (Rn.) zitiert.

9 Inzwischen hat sich auch der Bayerische Verfassungsgerichtshof damit in seiner Entscheidung vom 26.3.2018, Vf. 15-VII-16, anlässlich einer Popularklage des Aktionsbündnisses Parité in den Parlamenten (www.aktionsbuendnis-parite.de) befasst. Wie zu erwarten war, verfolgt das Gericht ein rein individualisierendes Demokratieverständnis und sieht daher in der ungleichen Repräsentation weder eine Verletzung der Wahlrechtsgleichheit noch des Demokratieprinzips.

10 Das Kommunalwahlrecht in Rheinland-Pfalz ermöglicht den Wähler*innen zu kumulieren und zu panaschieren, also auch gezielt mit ihren Stimmen Frauen (oder Männer) zu wählen.

11 Dies würde nicht bedeuten, dass die Unterrepräsentation anderer Gruppen nicht ebenso demokratische Legitimationsprobleme aufwerfen würde.

\section{Literatur}

Ahrens, Petra/Chmilewski, Katja/Lang, Sabine/Sauer, Birgit, 2018: Why the Fine Print Matters. Electoral Systems and Regulatory Policies for Implementing Party Quotas in Germany and Austria. Paper presented at the 25th International Conference of Europeanists, Chicago, March 2018.

Barber, Kathleen L., 2000: A Right to Representation. Proportional Election Systems for the Twenty-First Century. Columbus.

Dahlerup, Drude/Freidenvall, Lenita, 2005: Quotas as a „Fast Track“ to Equal Representation of Women. Why Scandinavia is No Longer the Model. In: International Feminist Journal of Politics. 7 (1), 26-48.

Dahlerup, Drude/Freidenvall, Lenita, 2009: Gender Quotas in Politics. A Constitutional Challenge. In: Williams, Susan H. (Hg.): Constituting Equality. Gender Equality and Comparative Constitutional Law. Cambridge, 29-52.

Davidson-Schmich, Louise K., 2016: Gender Quotas and Democratic Participation. Recruiting Candidates for Elective Offices in Germany. Ann Arbor.

Der Bundeswahlleiter, 2015: Ergebnisse früherer Bundestagswahlen. Wiesbaden.

Dreier, Horst (Hg.), 2015: Grundgesetz Kommentar. Band 2: Artikel 20 bis 82. Tübingen (3. Aufl.).

Epping, Volker/Hillgruber, Christian (Hg.), 2017: Beck'scher Online-Kommentar GG. München.

Foljanty, Lena, 2006: Repräsentation und Normkreation. In: Foljanty, Lena/Lembke, Ulrike (Hg.): Feministische Rechtswissenschaft. Ein Studienbuch. Baden-Baden, 193-213.

Gaßner, Helmut/Neusüß, Peter/Viezens, Linus, 2012: Verfassungsrechtliche Zulässigkeit einer zwingenden paritätischen Besetzung von Wahllisten im Kommunalwahlrecht Baden-Württemberg. Im Auftrag der Fraktion Bündnis 90/Die Grünen im Landtag von Baden-Württemberg. Berlin.

Holtkamp, Lars/Wiechmann, Elke/Eimer, Thomas, 2013: Lokale Disparitäten. Ursachen der Frauen(unter)repräsentanz in deutschen Stadträten. In: Polis Nr. 71, Hagen.

Ipsen, Jörn (Hg.), 2008: Parteiengesetz. Kommentar. München.

Isensee, Josef/Kirchhof, Paul (Hg.), 2005: Handbuch des Staatsrechts der Bundesrepublik Deutschland. Band III: Demokratie - Bundesorgane. Heidelberg (3. Aufl.).

Jarass, Hans D./Pieroth, Bodo, 2016: Grundgesetz für die Bundesrepublik Deutschland. Kommentar. München (14. Aufl.).

Jutzi, Siegfried, 2012: Gendergerechte Demokratie - eine verfassungsrechtliche Repräsentationsforderung? In: LKRZ. Heft 3, 9297.

Kersren, Jens/Rixen, Stephan (Hg.), 2009: Parteiengesetz (PartG) und europäisches Parteienrecht. Kommentar. Stuttgart. 
Kinzig, Silke, 2007: Auf dem Weg zur Macht? Zur Unterrepräsentation von Frauen im deutschen und U.S.-amerikanischen Regierungssystem. Wiesbaden.

Kletzing, Uta/Lukoschat, Helga, 2014: Engagiert vor Ort. Wege und Erfahrungen von Kommunalpolitikerinnen. Studie für das Bundesministerium für Familie, Senioren, Frauen und Jugend. Berlin

Laskowski, Silke Ruth, 2014: Pro Parité! Ohne gleichberechtigte Parlamente keine gleichberechtigten Gesetze und keine gleichberechtigte Gesellschaft! Eine juristische Streitschrift für ein modernes Wahlrecht. In: djbZ. 17 (3), 93-130.

Maunz, Theodor/Dürig, Günter (Hg.), 2017: Grundgesetz. Loseblatt-Kommentar. München.

Nedelsky, Jennifer, 2013: Law's Relations. A Relational Theory of Self, Autonomy, and Law. Oxford.

Pateman, Carol, 1988: The Sexual Contract. Stanford.

Phillips, Anne, 2004: Politics of Presence. Oxford.

Rodríguez-Ruiz, Blanca/Rubio-Marín, Ruth, 2012: On Parity, Interdependence, and Women's Democracy. In: Baines, Beverly/Barak-Erez, Daphne/Kahana, Tsvi (Hg.): Feminist Constitutionalism. Global Perspectives. Cambridge, 188-203.

Sachs, Michael (Hg.), 2014: Grundgesetz. Kommentar. München (7. Aufl.).

Schreiber, Wolfgang (Hg.), 2013: BWahlG. Kommentar zum Bundeswahlgesetz unter Einbeziehung des Wahlprüfungsgesetzes, des Wahlstatistikgesetzes, der Bundeswahlordnung, der Bundeswahlgeräteverordnung und sonstiger wahlrechtlicher Nebenvorschriften. Köln (9. Aufl.).

Steinberg, Rudolf, 2013: Die Repräsentation des Volkes. Menschenbild und demokratisches Regierungssystem. Baden-Baden.

Unger, Sebastian, 2008: Das Verfassungsprinzip der Demokratie. Normstruktur und Norminhalt des grundgesetzlichen Demokratieprinzips. Tübingen.

von Mangoldt, Hermann/Klein, Friedrich/Starck, Christian (Hg.), 2010: Kommentar zum Grundgesetz. Band 2: Artikel 20 bis 82. München (6. Aufl.) - 2018 (7. Aufl. i.E.).

Wild, Michael, 2003: Die Gleichheit der Wahl. Dogmengeschichtliche und systematische Darstellung. Berlin.

Williams, Susan H., 2009: Equality, Representation, and Challenge to Hierarchy. Justifying Electoral Quotas for Women. In: Williams, Susan H. (Hg.): Constituting Equality. Gender Equality and Comparative Constitutional Law. Cambridge, 53-72.

\title{
Addressing Supply-Side Hurdles to Gender-Equal Representation in Germany
}

\author{
LOUISE K. DAVIDSON-SCHMICH
}

\section{The Problem: Male Overrepresentation in Politics}

In January 1919 German women first received the right to exercise both passive and active suffrage at the national level. Three hundred women acted on their right to run for the Weimar Republic's National Assembly and thirty-seven were elected. The 
other $91 \%$ of the members elected were men (Bundeszentrale für politische Bildung 2014). In 2017, 1400 women ran for the Bundestag and 219 were elected (Bundeswahlleiter 2017,16$)$. While men's share of seats fell to $69 \%$, after a century of suffrage women still have not achieved political parity; in fact, the Bundestag contained a higher percentage of men in 2017 than it did in 2013. This lack of gender-balanced descriptive representation is not unique to Germany, however. In 2017, men occupied $77 \%$ of legislative seats worldwide (Interparliamentary Union 2017).

Political scientists have long investigated male political overrepresentation seeking both "demand-side" and "supply-side" explanations (e.g. Norris and Lovenduski 1993). Demand-side factors include both the formal and informal institutions that shape the actions of the "gatekeepers" who select candidates for the ballot. Supplyside discussions focus on the availability of men and women qualified and willing to run for office. This extensive body of research indicates that while both demandand supply-side factors play a role in women's political underrepresentation, formal institutions - particularly electoral gender quotas - can be created to solve demandside barriers to gender-equal descriptive representation by requiring gatekeepers to nominate a balanced slate of candidates. However, quotas do not address the supplyside of the equation. It is possible to increase women's descriptive representation in national legislatures - comprised of only a few hundred members in countries with millions of citizens - without solving the problem of male overrepresentation in the earlier phases of the political recruitment process in which candidates are identified and groomed for elective office. Below I elaborate upon these findings and their normative implications. I then turn to extant attempts to address supply-side hurdles to gender-balanced political representation in Germany, problematizing efforts to date and suggesting alternatives.

\section{The Causes: Supply- and Demand-Side Factors}

Extensive empirical evidence indicates that demand-side factors play a primary role in women's political underrepresentation in settings like Germany where politically ambitious individuals cannot self-nominate as candidates but instead must be selected by gatekeepers to appear on the ballot. Gatekeepers are often men who are prone to selecting other men from their social networks to run for office; this informal reliance on homosocial capital inflates the number of male candidates (Bjarnegård 2015). Formal mechanisms such as quotas were developed to constrain such demand-driven causes of women's exclusion from politics by requiring gatekeepers to select female candidates; globally, quotas have successfully increased gender balance in elective offices (Franceschet/Krook/Piscopo 2012).

In Germany too, voluntary party promises to include women on party lists have helped curb - but not eliminate - male overrepresentation (Davidson-Schmich 2016). The Greens, Social Democratic Party (SPD), and Left Party all promise gender parity on candidate lists for the Bundestag; the Christian Democratic Union's 
(CDU) quorum calls for women to hold at least one third of list places. In contrast, the Christian Social Union (CSU), Free Democratic Party (FDP), and the Alternative for Germany (AfD) do not use quotas for their federal lists; no party utilizes a quota for directly-elected Bundestag seats. The results of the 2017 national election clearly demonstrate quotas' effectiveness (see Figure 1). While gender parity has been reached among Members of the Bundestag (MdB) elected from party lists drawn up using quotas, men make up $79 \%$ of the MdB who reached the Bundestag via quota-less lists or by winning a direct mandate.

Figure 1: Demand and Supply Side Factors and Bundestag Representation

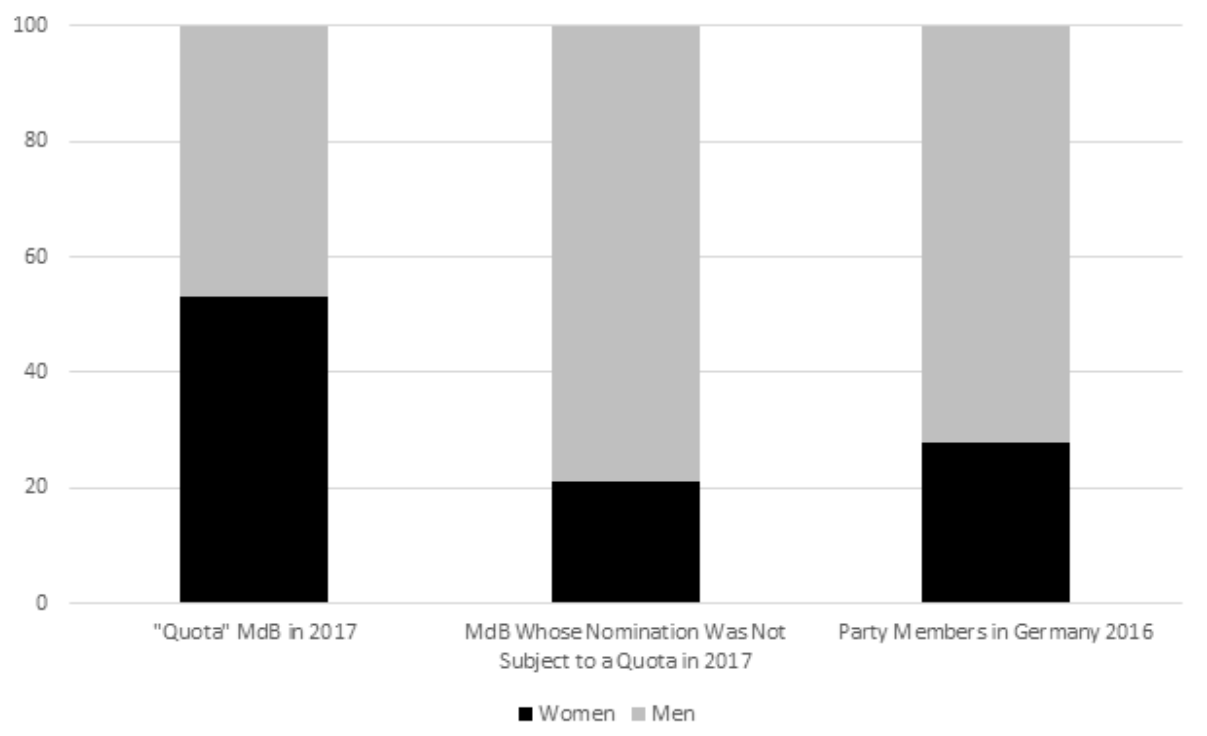

Sources: Bundestag 2018; Niedermayer 2016.

One way to eliminate this remaining gender imbalance in the Bundestag would be to expand the use of quotas. For example, the CDU could raise its quorum to $50 \%$ and the CSU, FDP, and AfD could voluntarily adopt affirmative action policies (Frankfurter Allgemeine Zeitung, 16.4.2018). Alternatively, as has been proposed by leading women in the CDU and SPD, Germany could adopt an electoral law quota such as that employed by Belgium, under which gender-imbalanced candidate lists are not permitted to appear on the ballot (Frankfurter Allgemeine Zeitung, 8.3.2018). Achieving gender parity in the other 299, directly elected, Bundestag seats poses more of a challenge given that each district only elects one $\mathrm{MdB}$, but it is not impossible. Skye Christensen and Gabrielle Bardall (2016) identify several quota mechanisms compatible with plurality electoral systems, such as rotational quotas under which parties must replace a retiring incumbent with a candidate of the opposite sex. 
Even if proposals to expand the use of quotas could generate gender-equal descriptive representation in the Bundestag, however, it would not address the parties' imbalanced supply of male and female candidates. Across the long-term democracies, research often finds that there are far more men than women in the pool of potential candidates (Wolbrecht/Campbell 2007, Preece/Stoddard 2015). In order to establish whether supply-side factors hinder gender equal participation in Germany it is first necessary to identify the "candidate pool" from which elective office holders are selected.

The Federal Republic has been termed "the party state" for the important role the Basic Law gives to political parties in terms of interest aggregation and candidate selection (Langenbacher/Conradt 2017, 137). Parties control most nominations for European Parliament, federal, and state legislative seats; while non-partisan lists are more common at the local level, individuals aspiring to a political career beyond the local level require a party affiliation. German electoral law grants local party members final say over candidate selection for directly-elected seats and their delegates' approval for party list candidates. Their primary preference is for a candidate who will advocate for their party, and the most common way for an aspiring politician to demonstrate such party loyalty is to join the party and become active within it. As a result, local party organizations represent the bottom rungs of the political career ladder in Germany. The vast majority of Members of the Bundestag have held locallevel inner-party offices and worked their way up the organization's hierarchy; importantly, such a party background is required for moving into positions of influence within the Bundestag once elected (Ohmura/Bailer/Meissner/Salb 2018).

Thus in order to evaluate the gender balance among potential candidates in Germany, it is necessary to examine the membership of German parties. Figure 1 clearly demonstrates that a pronounced supply problem indeed exists in the Federal Republic, despite over three decades of quota use. In 2016, $72 \%$ of German party members were men (author's calculation based on Niedermayer 2016). ${ }^{1}$ Even political parties sending roughly equal percentages of men and women to the Bundestag, such as the Greens, do not have gender parity among their rank and file (see Figure 2). For example, men still make up $61 \%$ of all Green party members (the lowest percentage of all major parties) and this figure has only decreased $3 \%$ since 2000. Parties such as the FDP that send very male-dominated parliamentary party groups to Berlin, therefore, are more representative of their candidate pools. While changing demandside factors and adopting gender quotas has improved women's descriptive representation in elected bodies, these policies have not altered an underlying supply-side problem in the Federal Republic. 
Figure 2: Male MdB and Party Members in Percent

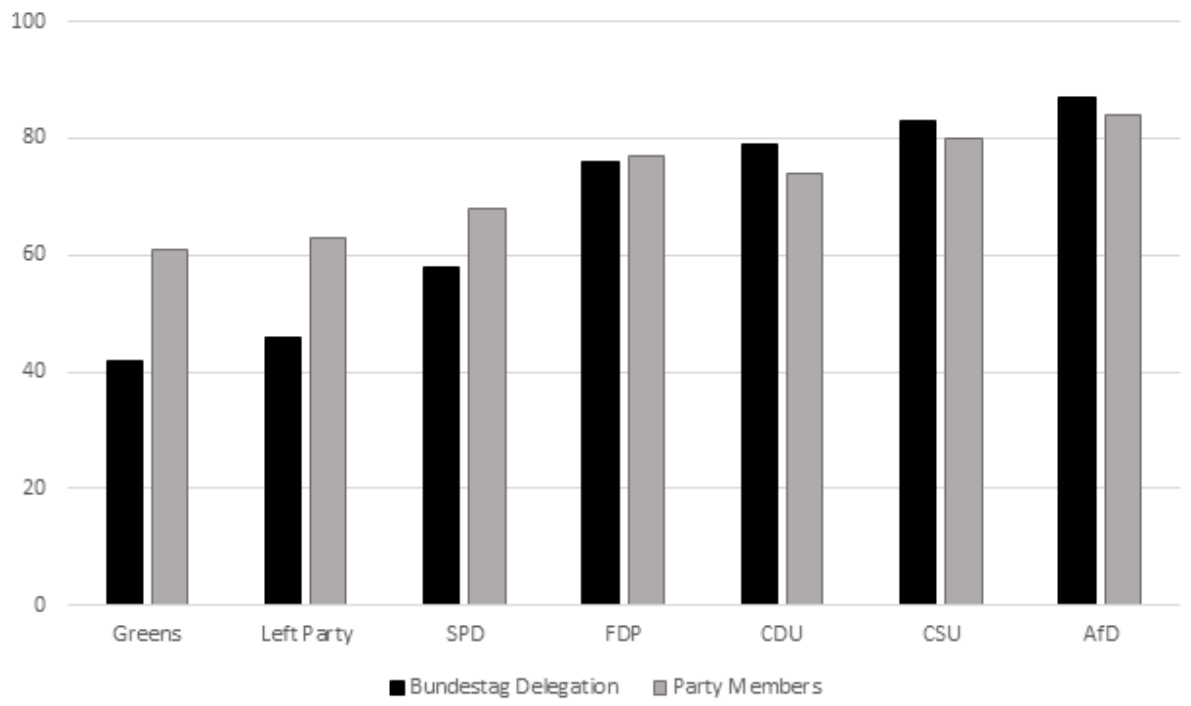

Sources: Bundestag 2018, Niedermayer 2016.

A century after suffrage, then, men remain overrepresented not only in parliament but also in the pipeline funneling citizens into positions of political power. Women's exclusion from this side of the political recruitment process has important implications for democracy. First, Article 21 the Basic Law charges parties with performing interest aggregation in a manner consistent with democratic principles. Parties' consistent failure to attract women, however, means not only that more potential candidates are men than women, but also that men have more of a say in developing party platforms and selecting candidates than do women. For example, the current "GroKo" government was placed into office after being approved by the SPD's rank and file $-68 \%$ of whom are men. A national election with such a gendered imbalance in suffrage would certainly not be considered consistent with democratic principles. Second, a lack of competition from women interested in running for office inflates the chances of "mediocre men" appearing on the ballot (Besley et al. 2017). Gender imbalance in the candidate pool thus reduces the quality of available candidates. Third, because very few Germans join political parties, and those that actually do are not typical of the underlying population as a whole (Davidson-Schmich 2016), citizens' representatives are drawn from a very narrow subset of society. Women's underrepresentation in this small pool narrows the diversity of options even further. To ensure that German democracy in the twenty-first century is more representative of the citizenry than it is now, then, the supply-side problem must be addressed. 


\section{Fixing the Supply-Side Problem by “Fixing" Women}

The recognition of a gendered candidate pipeline has not gone unnoticed, and in countries across the world efforts have been undertaken to encourage women to develop political ambitions and the qualifications needed to run for elective office. Most efforts have focused on changing women themselves, rather than the institutions through which candidates are recruited. Foremost among these initiatives have been efforts to boost women's candidacies by implementing training programs; these initiatives are now found in nearly every democratic or semi-democratic country around the world and have been sponsored by parties, government programs, and NGOs (Piscopo 2017).

In the Federal Republic, most efforts to fix the supply-side problem have come from political parties. It is not lost on these organizations that they lack female members and, for organizations employing quotas, that they require a pool of female candidates to comply with their own affirmative action policies. Over the years most major German parties have undertaken efforts to attract more women to local branches of their parties. The FDP has made multiple attempts to do so, beginning with their 2003 Women's Campaign (Davidson-Schmich, 2016, 32) and continuing through April 2018 (Frankfurter Allgemeine Zeitung, 16.4.2018). In 2012, the Left Party founded a "Bundesrat LINKE Frauen" in order to coordinate the party's relationships with feminist groups outside the party in hopes of gaining more female members (Die Linke 2011). That same year the Greens started a "Project Fifty Fifty" to increase female membership (Bündnis 90/die Grünen 2012). The Berlin-based "More Women in the SPD" initiative has placed postcards and buttons featuring slogans such as "bitch" and "diva" in women's restrooms across the city in an attempt to drum up their female membership (SPD Berlin 2018). The CDU's You Tube Channel features multiple videos in which women are encouraged to emulate Angela Merkel and get involved in politics (e.g. CDUTV 2013).

In addition to such campaigns, in the late 1990s parties employing quotas began formal mentoring programs pairing interested women with female office holders in their area in order to encourage the former to join the party, become active in it, and run for office (McKay 2004). The FDP and CSU followed in 2008 and 2011 (Bundesvorstand der FDP 2007, Frauen Union 2016). Mentoring offers women a chance to shadow female politicians as they carry out their duties. Parties have also developed training programs to help women develop the skills, such as public speaking or presenting oneself in the media, needed to be successful in party politics. Parties also hold feminist consciousness raising style discussions for women to share examples of sexism in politics. One study of female local party leaders in Germany found that over half of them were aware of party-sponsored training programs for women (Davidson-Schmich, 2016, 179).

Since the turn of this century, however, the percentage of female party members has barely budged as a result of the above efforts. In 2016, women made up $42 \%$ of new Green party members and less than a third of the new entrants to Germany's other 
major parties (Niedermayer 2016, 30). These German efforts to correct supply-side problems, as is the case elsewhere, have sought to both entice women into existing male-dominated party organizations and to "fix" women by improving their ability to navigate existing party political structures and engage in the behaviors required by these institutions.

Yet feminist institutionalist analysis tells us that political institutions such as parties, their political recruitment practices, and elective office itself, are highly gendered, and based on masculinized characteristics, preferences, and life courses (Abels/ Mushaben 2012, MacRae/Weiner 2017). Rather than submitting to being "fixed" by the above training programs, women are voting with their feet and devoting their energies to organizations other than parties. Post-industrial democracies such as the Germany have large populations of well-educated, civically engaged female citizens who do not shy away from participation in more feminized institutions. Women cross-nationally, including the Federal Republic, participate more often in informal social movements or activities like boycotts than they do in formal political organizations such as parties (Coffé/Bolzendahl 2010; Hess-Meining 2005, 395). In Germany, women are just as likely to vote and sign petitions as men and even more likely than men to be active in charitable or education-related groups (Hess-Meining 2005, 395). These organizations do not require extensive years-long membership campaigns or reeducation programs to convince female citizens to join. In contrast, political parties across the ideological spectrum consistently fail to attract genderequal memberships despite efforts to do so.

\section{Fixing the Supply-Side Problem by Fixing Parties: Identifying Gendered Informal Institutions}

While formally parties welcome female membership, their informal institutions, work to deter gender-balanced participation. Despite quotas, joining a German party means signing up for a club containing mostly men; the more thinly populated a region is, the more pronounced this problem becomes, a local branch organization may literally only contain three women (Davidson-Schmich 2016, 93-95). Because local party groups contain mostly men, informal party norms are highly masculinized, creating an atmosphere in which, on average, men feel more comfortable than women. ${ }^{2}$ Changing parties' masculinized rituals, rather than attempting to alter women, represents a more fruitful avenue for promoting gender-equal participation in public life. Reforming the informal institutional structures inhibiting a broad range of potential candidates from coming forward should in turn address the supply-side problem.

\section{Data and Methods}

The empirical basis for identifying supply-side barriers comes from 41 semi-structured, in-person interviews with men and women who were (or could have easily 
become) party members or candidates for elective office by virtue of their active contributions to party or public life in Germany. In practice, interviewees' experiences ranged from never having joined a party despite an interest in politics, to serving multiple terms in the Bundestag. Investigating civically-engaged people who consciously decided not to pursue party membership allows me to better understand supply-side problems than would concentrating only on those people who are party members. One section of the interview focused on respondents' own decision to join, or not join, the local branch of a political party. For those interviewees who had gone on to become an active member, the interview also discussed any attempts they had made to recruit other Germans to become party members. Quotations from interviewees appearing in this article were selected because they were representative of arguments made by a number of respondents. Interviewees came from all age groups and an array of rural and urban locations across the country. Some interviewees were not members of any political party; others had joined the CDU, CSU, FDP, Greens or SPD. All interviewees were generous with their time and insights. In order to protect their privacy, I do not use their names here, but other identifying characteristics have not been altered. A list of interviewees' backgrounds is available from the author upon request.

Respondents identified a number of reasons for becoming active in their political parties. The most common was a desire to address a particular policy issue or improve the community; other frequent reasons for joining included being inspired (or asked) by prominent politicians, family members or friends, a desire to have fun and meet new people, and the belief that joining a party would be career-enhancing. The analysis below, in contrast, focuses on reasons interviewees gave as to why they decided against becoming a party member or why, in their experience, others had decided not to do so. Some commonly mentioned reasons - for example, a generalized lack of trust in parties and politics - are helpful in explaining declining party membership overall, but less helpful in explaining the gendered imbalance in participation.

However, interviewees living across Germany and representing a range of parties also consistently identified several informal aspects of party life that they believed deterred women in particular from joining or participating more fully in these critical, grassroots-level party organizations where political careers begin. The informal institutions most frequently identified included the groups' masculinized ethos, discourse, and time management - in other words, the "who, when, where, what and how" of local political party life. These practices in turn create a vicious cycle, deterring a gender balance among local party members that could change informal rituals and attract a more diverse membership. Below I discuss these informal norms in turn and then theorize how these practices could be addressed in order to achieve gender-equal participation in German democracy. 
Who: One in ten female interviewees mentioned a male-dominated atmosphere as a reason they were (initially) reluctant to join a party. Because they were the only woman, or one of few women, present at party meetings, and often considerably younger than others present, many women reported that they felt out of place and uncomfortable. One seventy-year old Social Democrat recalled that she had been active in politics as a student, but after she got married and moved to her husband's rural hometown, she went to a meeting of the local SPD and found only older men present. Then, in her words, "I thought to myself, no way" and did not return to the party for years. A 2009 study observed similar reactions to Left Party organizations in eastern Germany (Holtkamp/Wiechmann/Schnittke 2009, 54). A state legislator remembered the first time she went to a meeting of the CDU's youth wing in the 1980 s, "there were only young men there in pin stripe suits" leading the gathering. A female Free Democrat recalled going to an FDP working group meeting in her city in the early 2000s to encounter only older men. A 50-year-old CDU member described her current fellow party members as "men with beer bellies."

Some women interviewed also reported outright sexism in their male-dominated party organizations. A Christian Democrat remembered being one of two women at a meeting of the party's youth wing when officers were chosen in the 1980s; when the other woman, a dental hygienist, volunteered to become the organization's treasurer, the men told her she should "stick to drilling teeth" because women didn't know about accounting. A 55-year-old Green state legislator currently in office noticed that, because she is quite petite, men often simply talk over her head at each other, ignoring her altogether. Prior to being elected she was employed in a male-dominated technical field where she encountered such behavior less often. A female Free Democrat in her 30s recounted going to an FDP economics working group meeting and having older men ask her what a "little miss" (Fräulein) like herself was doing at a meeting about economic issues. Given that many interviewees joined a party in order to have fun and make friends, such experiences are likely to have a strong deterrent effect.

When and Where: In addition to who is at party meetings, when party groups choose to meet also creates a masculinized ethos. Over one third of interviewees cited when and where party organizations met as hindering women's participation. Because parties are volunteer organizations whose members generally work outside the home, meetings usually occur on the evenings and weekends, outside paid working hours. Due to the gendered division of labor in society, however, these are times when women pursue unpaid domestic responsibilities, cooking dinner, putting children to bed, cleaning or doing laundry. One SPD leader noted,

In the younger years it's the same (for girls) as boys in school and at the university... but (later) it becomes difficult to activate them and get them involved. ... In general it is so that in the biography of women politics is unattractive because the political parties conduct 
their activities in the classic old times in the evenings. That often creates a big hindrance for those in their middle years to take part in politics.

Moreover, where parties choose to get together may also serve as a deterrent to some women. One member interviewed by Isabelle Kürschner described going to CSU meetings as, "you go into these smoky rooms." Another recalled, "the first thing that shocked me when I went to my first party meeting, held in a back room in my town, was that the members, who seemed like very old men to me, looked at me strangely and said I had mistakenly come into the wrong room" (2009, 135; trnsl. LKDS). A third observed, "you have to be able to tolerate alcohol.... Political decisions are also made at night at the bar" (quoted in Kürschner 2009, 204; trnsl. LKDS).

This type of politicking is not limited to quota-less parties such as the CSU, however. One northern German woman interviewed said her teenage daughter had recently decided against joining the local youth wing of the Social Democrats because the meetings were too "smoky and macho." One woman from southwestern Germany who heads a state-wide women's organization but who is not an active party member, suggested that the timing and location of party activities had deterred her too from further involvement with the SPD. She noted, "important agreements are reached over beer or wine" at times when she is at home with her family; gaining political influence under such circumstances appears to her to be a "Sisyphean task." The leader of the SPD's women's auxiliary organization in a northern state recalled a plan she had to hold breakfast meetings at a restaurant rather than an evening meeting in a bar, but lamented, "that's the kind of thing that men reject quickly; they say, you'll just get together and eat, but that's not true. Women would really like to have a different atmosphere. That doesn't mean that they aren't just as political or not getting down to business, just that the atmosphere really makes a difference." If women are unable to attend a party meeting due to the time it takes place, or feel uncomfortable if they are able to attend, they are unlikely to return.

What - The Type of Discourse and Substantive Focus: In addition to off-putting meeting times and locations, over a quarter of interviewees argued that the substantive content of party meetings were alienating to many women. One Green state legislator argued that while women viewed such occasions as a time to discuss policy substance (Sachfragen), men considered meetings an opportunity for self-presentation (see also Kürschner 2009). One Left Party member sighed, "men are superb self-promoters;" an SPD member concurred and believed this behavior was less frequent among women (Holtkamp/Schnittke/Wiechmann 2009, 56; trnsl. LKDS). An interviewee concluded women prefer interest groups and social movements to political parties, as the former tackle problems directly. A CDU state-level Minister argued that women in her party simply wanted to make good policies, but men "want to become this (position) or that (position)." A woman who ultimately decided not to join the SPD recalled attending a party meeting to discuss environmental issues in the early 2000s. One female member made an impassioned speech about local environmental problems, urging her fellow party members to take up these concerns; 
some men present argued that the party should focus on other, non-environmental issues more likely to win votes. When she disagreed, a male colleague argued, "do you want to be right or do you want to win?" The interviewee maintained that women "had a different relationship to power" than men and, were more concerned about being substantively "right" whereas men were more concerned with winning and "self-affirmation." She concluded that party meetings like these had deterred not only herself but other women as well. A woman who studied political science and began a career working for non-profit development agencies agreed. While she had wanted to become a Green party member to make development-related policies based on the merits of particular ideas, she instead found party members' reasoning dominated by "tactical reasons and gaining political influence." She found this tendency "rather off-putting" and decided not to join the party, echoing the findings of experimental research that finds men to be more motivated by power-related goals than women, who are driven by more communally focused goals (Preece/Stoddard 2015). Given that the most frequent reason interviewees gave for becoming active in a political party was a desire to promote a particular policy or solve societal problems, discourse that focuses on tactics and status rather than substance is especially alienating.

Interviewees also noted that if women desired to get ahead in politics, and in turn make the substantive policy changes they favored, they were required to engage in the same jockeying for power and self-promotion, even if they were uncomfortable with it. Otherwise, as one male party leader observed, even a hard-working, talented woman will "get lost in the shuffle." One 51-year-old Christian Democrat from southern Germany argued that to develop the public visibility required for a career in party politics, she had to frequently appear in the local newspaper, which required running to the front of any group about to have its picture taken. While she claimed her male counterparts were quite willing to stand front and center, regardless of how good looking they were, "I do not like to do this; it's uncomfortable to be in the foreground but it comes with the territory." A northern Green state legislator agreed, lamenting that as a prominent party member, "you have to read about yourself in the newspaper. And not on the back pages either, but on page one, and if you are unlucky, with a picture too."

Obtaining a leadership position within the local party group and ultimately a ballot nomination to run for office requires not only self-promotion but also competition with fellow party members, another behavior that experimental research indicates is more attractive to men than to women (Preece/Stoddard 2015). One 50-yearold mother who became an SPD state legislator reflected, "My predecessor decided not to run again and then the county party organization began to look for a successor. ... At first I thought, no, I can't do that. ... I was a little scared of getting into a competition (for the nomination) with people with whom I was friends. ... That seemed like it would be uncomfortable ..." Another state legislator had pondered calling all her friends in the party and asking them to come to the nominating meeting during 
which candidates were selected, but she decided against it, not wanting to appear to be a "solicitor." A female CDU state legislator described the process of visiting all the local party groups in her electoral district to shore up support for her candidacy as akin to "streetwalking."

How - Time Management: Self-promoting discourse and inner-party competition creates externalities that cause parties to further alienate some women. As each party member endeavors to call attention to him or herself, meetings drag on and become redundant. Fifteen percent of female interviewees criticized this aspect of political party life as a deterrent to gender equal participation. One Christian Democratic woman who was a doctor before entering a full-time state legislative position mourned, "When I worked as a physician, I saw thirty patients a day and accomplished something for each of them. (In party politics) I can sit all day in a meeting and nothing will have gotten decided." While of course not all men enjoy sitting through long-winded speeches, because of the gendered division of labor in society places more domestic responsibilities on women, men simply have more time available to devote to such long meetings than do women. As a female Green state legislator and mother of two put it, "sometimes you also have to make sure that there's something in the fridge or that maybe you do a load of wash" and it would be nice "if you didn't get home again at 11:30 PM."

Gender quotas do not appear to have altered this problem, which was also noted in Bärbel Schöler-Macher's 1994 study of CDU, SPD, Green, and FDP women across Germany. One female party member she interviewed remarked, "how, and at what times, party meetings take place, with what length and what intensity people are sometimes just blabbing on and on. When this eternal yakking starts, then I think to myself, 'My God, you could be running the washing machine right now. You could be doing this or that. it's really disgusting the time that is wasted (in party meetings.)' (quoted in Kürschner 2009, 223; trnsl. LKDS)." Over a decade later, a study of local party members in the CDU, Greens, Left Party, and SPD found that "virtually all interviewees, regardless of party" complained about this redundant type of discussion in which "everything has already been said, but not by everybody" (Holtkamp / Wiechmann/Schnittke 2009, 56; see also Kürschner 2009, 222).

These hurdles create a vicious cycle: because women are less likely to join political parties than men, parties remain male-dominated and continue to require time consuming, self-promoting behavior often at the expense of substance. This perpetuates long meetings, further deterring time-strapped women and continuing the cycle.

\section{Solving the Supply-Side Problem: Policy Recommendations}

Over the past several decades all German parties have undertaken multiple national-level campaigns to increase their female grassroots membership and have tried to train women in self-promoting, competitive behaviors such as public speaking and media presentation. While these efforts may appeal to some women and inspire 
others to look into attending a meeting of the local party organization, if such gettogethers are held in masculinized spaces filled mainly with men, or if they drag on and on as male members jockey for position or repeat each other's comments, it is unlikely that once-interested women will continue attending local party functions. Below I address in turn ways in which the masculinized ethos, discourse, and time usage discussed above could be altered in a way to make parties more welcoming not only to women, but to a broader array of men as well.

Before turning to these suggestions, it is important to consider another solution to the supply-side problem: selecting candidates from outside the party rank and file where a more gender-balanced candidate pool could be found. Nominating such "Seiteneinsteiger" does indeed occur and about 10\% of Bundestag deputies are "career changers" without extensive party political involvement. Perhaps because political parties are searching for women to fulfill gender quotas, women are common among these "career changer" deputies. However, members of parliament lacking party experience and connections are less likely to obtain legislative positions of power and influence than deputies than "party animal" deputies who have deep roots within the party (Ohmura et al. 2018). ${ }^{3}$ Making parties more attractive to women, rather than recruiting marginalized candidates, would better achieve gender parity in politics.

Who: For parties currently without quotas, adopting affirmative action regulations for inner-party offices may be a partial solution. If quotas propel women into leadership posts, they may be able to alter the time, location, or tenor of party meetings to become more conducive to other women's participation. Several female party leaders interviewed argued that as soon as they became head of their precinct organization, they had tried to make their group more female-friendly; such efforts may indeed inspire more women to join that particular branch of the party. One politically ambitious college student described her selection criteria for choosing a party, "\#1: "What does the party stand for? Where do I fit best (ideologically) and \#2: What's this party like in my town? What do they offer? How is the party group composed?" She ultimately decided to join the SPD's branch organization, led by another woman. Older women reported that instances of blatant sexism had declined over the years and indeed, female members of parties with quotas currently in their late 20s and early 30 s recounted fewer negative experiences with overtly sexist party organizations than older women or women in parties without quotas. Quotas like the Greens' which mandate that women are equal co-chairs of local party groups are best suited to placing women in positions of power where they may alter informal norms and, indeed, Green interviewees problematized male-normed party practices less often than members of other parties.

Both the Green and the Left parties' statutes also recognize the problems of childcare conflicts and masculinized discourse, and they require that child-care be provided at national-level party meetings and that discussions there end when no further female speakers can be identified. These two parties in turn do have the highest percentage of women members in Germany. However, both organizations still con- 
tain a majority of men. The above-mentioned rules regarding child care and genderbalanced discussions only apply to infrequently-occurring, high-level gatherings. They do not pertain to the low-level, day-to-day interactions that shape whether or not politically-interested individuals decide to become involved in a party in their own community, taking the first step needed for a successful political career. Even parties employing quotas remain male-dominated, especially outside of large cities, and female interviewees from the Greens and SPD were still conscious of being in the minority decades after quota adoption.

Because local-level party groups (Ortsvereine) are small in size, these groups are particularly prone to being almost exclusively male. In thinly-populated regions, or where a specific party organization has very few members, it may be preferable to encourage politically-interested women away from their local party group toward engagement with a county-level branch with more members instead. There the likelihood that female newcomers find themselves the only woman - or one of few - in the room is decreased; moreover, the county level is still local enough to serve as a solid base for a future political career. Encouraging existing female members to be sure to attend as many meetings as possible, and to bring a female friend when they do, could also help feminize party organizations.

What: However, efforts designed to attract generic party members are not the most fruitful way in which to solve the supply-side problem. Because women report dissatisfaction with precinct-level party meetings and since women in Germany and elsewhere (Dow 2009, Westle 2009) remain on average less interested than men in politics in general - but not in certain issue areas - parties would better endeavor to recruit women for their substantive working groups (Arbeitskreise) on specific political topics. These bodies' primary function is to develop policy stances on issues of concern to many women such as education, health, poverty, gender inequality, and foreign policy. Experimental evidence indicates that women are more likely to become politically ambitious when the nature of political life is reframed from focusing on competition and self-promotion to involving collaborative efforts to fulfill communal goals ( Preece/Stoddard, 2015) - the point of working group discussions. Indeed, many interviewees who decided to become active in their parties decided to do so despite the drawbacks because they felt it was the best way to address substantive issues of concern to them. One Christian Democratic member of a state legislature maintained, "In my opinion, a part of yourself has to be involved. If there's not something that affects you personally, that you can advocate on behalf of, then I don't think you go into party politics. ... I think without that politics are not worth pursuing." One 30-year-old Social Democrat elected to her local council noted that while people involved in social movements could lobby elected officials, only those sitting on the council could make decisions about policy; she was glad she had stayed active in her party because, "I'm now actually in a position to do something for the community." To the degree that working group events attract more women than do "party" meetings, the "who" problem may be more easily addressed in this context as well. 
Given that parties have such groups devoted to issues of interest to women currently underrepresented in parties - such as low-income women, businesswomen, or female immigrants (Davidson-Schmich 2016) - this strategy also appears particularly useful in helping broaden the diversity of female party members. Party membership may follow, rather than precede, involvement with a policy-related group.

When and Where: Changes to make party meetings - especially working group sessions - more female-friendly could include organizing activities in locations other than pubs or back rooms, such as community or youth centers, cafes, public places of business, or parks. Organizing breakfast meetings, perhaps immediately following the start of the school day or other times when child care is readily available, could also create a less-masculinized ambiance than a late-evening session. Shifting party work or decision-making away from in-person meetings held evenings and weekends, and into cyberspace instead would allow women to participate from home or at times more conducive to their schedules. For example, e-votes could be taken to decide issues, conversations could be held via conference call, or work could be performed by smaller groups of party members meeting during the day when childcare is available. These changes would be especially helpful to rural women (and men) who otherwise find party life overly time consuming as it often requires travel from one end of a large precinct to another. Critical to the success of such endeavors, however, is also the presence of women in virtual party life. Germany's Pirate Party, famed for its use of social media, has difficulty attracting female members in part because of its highly-masculinized, conflictual, at times openly sexist, on-line discourse (Meiritz 2012).

How: Women are often deterred from participation in face-to-face party groups due to the long-winded, self-promoting nature of discourse in party meetings. Calling members' attention to this habit and consciously trying to limit sexism or verbosity can be done in a humorous manner, and streamlined meetings would give all members more time to pursue other interests. Doris Bucholz, the head of the FDP's Liberal Women auxiliary organization recounted her efforts to this end, "One time in a (county-level) Board Meeting someone said in making a point, 'Let's pretend we are as dumb as a woman....' After that we put a 'punishment piggy bank' (Strafschwein) on the table. You had to put in a Euro if you took a cell phone call during the meeting and two Euros if you made a sexist comment. It helped" (Schulte 2013). Such piggy banks could be used to deter repetitive comments as well. In addition, parties could develop programs, based on extensive existing business expertise, to train local party leaders on how to more efficiently conduct meetings.

\section{Conclusion}

The above-outlined suggestions would not only make grassroots political parties more welcoming to women, they are unlikely to deter men. In fact, they may in turn welcome a broader array of men to these vital institutions that serve as the 
first rung of the political career ladder in the Federal Republic. Women are not the only underrepresented group in German parties; single parents and parents of young children are less likely to be found among active party members than within the general population (Davidson-Schmich 2016, 82-3). One Social Democratic father interviewed stressed he was limiting his involvement with his local party group because, "I want to be the one to raise my children and (party activities) cause me to be away from them too often ... when I should be home putting them to bed." Moving toward virtual decision making or daytime meetings would mitigate this barrier to political involvement for all parents regardless of sex. Holding events in smoke-free public buildings rather than pubs would benefit all members' health and attract people dissuaded by drinking and smoking. Running more efficient meetings with less repetition would free up party members to pursue other activities of interest. One study of local politicians found that all party members surveyed, regardless of sex, identified needlessly time-consuming discussions as their least-liked aspect of political debate (Holtkamp/Wiechmann/ Schnittke, 2009, 56).

In sum, altering the informal norms of party life by changing where and when grassroots organizations meet, who is present, and what and how they discuss rather than trying to persuade women to adopt to masculinized institutions - would go far to address the still gaping supply-side hurdles to gender-equal political participation decades after quota adoption and a century after suffrage.

\section{Notes}

1 Figure includes membership in all parties represented in the 19. Bundestag.

2 The membership figures above clearly indicate that some women do feel comfortable participating in male-dominated local party organizations; low rates of party membership overall also suggest that many men may not feel comfortable in these bodies. On balance, however, more women seem to be deterred from joining than men.

3 Moreover, career changers are also usually elected via party lists; they rarely have the connections to become candidates for directly-elected seats.

\section{References}

Abels, Gabriele/Mushaben, Joyce M. (Eds.J, 2012: Gendering the European Union: New Approaches to Old Democratic Deficits. Basingstoke.

Besley, Timothy/Folke, Olle/Persson, Torsten/Ricke, Johanne, 2017: Gender Quotas and the Crisis of the Mediocre Man. Internet: http://microeconomicinsights.org/gender-quotas-crisismediocre-man/ (13.6.18).

Bjarnegård, Elin, 2015: Gender, Informal Institutions and Political Recruitment. London.

Bundesvorstand der FDP, 2007: Das Mentoring Programm der FDP: „Top-NachwuchsTalent.” Internet: https://www.fdp.de/files/408/BuVo-Mentoringprogramm.pdf (23.4.18).

Bundeswahlleiter, 2017: Sonderheft Wahlbewerber. Die Wahlbewerberinnen und Wahlbewerber für die Wahl zum 19. Deutschen Bundestag. Internet: https://www.bundeswahlleiter.de/dam/jcr/ f44145b0-99b6-4e87-bec9-b8c7dd4aa79a/btw17_sonderheft_online.pdf (13.6.18). 
Bundeszentrale für politische Bildung, 2014: Vor 95 Jahren: Erste Frauen im Parlament. Internet: http://www.bpb.de/politik/hintergrund-aktuell/179230/1919-erste-frauen-im-parlament-18-022014 (13.6.18).

Bündnis 90/die Grünen, 2012: Warum wir mehr Frauen brauchen. Internet: https://www.gruene. de/partei/projekt-fifty-fifty/warum-wir-mehr-frauen-brauchen.html (13.6.18).

CDUTV, 2013: Höhepunkte der Veranstaltung „Frauen für Merkel - Gut für Deutschland.“"Internet: https://www.youtube.com/watch?v=5Kp6q9xHvzQ (13.6.18).

Christensen, Skye/Bardall, Gabrielle, 2016: Gender Quotas in Single-Member District Electoral Systems. In: Politics, Groups, and Identities. 4 (2), 246-267.

Coffé, Hilde/Bolzendahl, Catherine, 2010: Same Game, Different Rules? Gender Differences in Political Participation. In: Sex Roles. 62 (5-6), 318-333.

Davidson-Schmich, Louise K., 2016: Gender Quotas and Democratic Participation: Recruiting Candidates for Elective Offices in Germany. Ann Arbor.

Die Linke, 2011: Bundesrat LINKE Frauen gegründet. Internet: https://www.linksfraktion-ohz.de/ nc/inhalt/archiv/detail/news/bundesrat-linke-frauen-gegruendet/ (13.6.18).

Die Linke, 2017: 6. Gleichstellungsbericht der LINKEN. Internet: https://www.die-linke.de/fileadmin/download/frauen/berichte/2018-04-13_sechster_bericht_zur_geschlechtergleichstellung_in_der_linken.pdf (13.6.18).

Dow, Jay K., 2009: Gender Differences in Political Knowledge: Distinguishing CharacteristicsBased and Returns-Based Differences. In: Political Behavior. 31 (1), 117-136.

Franceschet, Susan/Krook, Mona Lena/Piscopo, Jennifer M., 2012: The Impact of Gender Quotas. Oxford.

Frankfurter Allgemeine Zeitung, Barley und Kramp-Karrenbauer wollen Wahlrechtsänderung prüfen. 8.3.2018. Internet: http://www.faz.net/aktuell/politik/inland/cdu-und-spd-politikerinnenwollen-frauenquote-im-wahlrecht-15483926.html (13.6.18).

Frankfurter Allgemeine Zeitung, Über Tabus Nachdenken: Die FDP prüft Einführung einer Frauenquote. 16.4.2018. Internet: http://www.faz.net/aktuell/politik/inland/ueber-tabus-nachdenken-fdp-prueft-einfuehrung-einer-frauenquote-15544451.html (13.6.18).

Frauen Union, 2016: Startschuss: Mentoring-Programm der FU-Unterfranken Jahrgang 2016/17. Internet: http://www.fu-bayern.de/common/fu/content/Verbaende/bezirksverbaende/Unterfranken/PDF-Dateien/Mentoring-Programm/Jetzt_gehts_los_2016.pdf (13.6.18).

Hess-Meining, Ulrike, 2005: Politische Partizipation und bürgerschaftliches Engagement. In: Cornelissen, Waltraud (Ed.): Gender Datenreport. Bundesministerium für Familie, Senioren, Frauen, und Jugend. Berlin.

Holtkamp, Lars/Wiechmann, Elke/Schnittke, Sonja, 2009: Unterrepräsentanz von Frauen in der Kommunalpolitik. Heinrich Böll Stiftung. Berlin.

Interparliamentary Union, 2017: Women in National Parliaments, 1 January. Internet: http://archive.ipu.org/wmn-e/arc/world010117.htm (13.6.18).

Kürschner, Isabelle, 2009: Männern überlassen wir's nicht! Erfolgreiche Frauen in der CSU. Baden-Baden.

Langenbacher, Eric/Conradt, David P., 2017: The German Polity, $11^{\text {th }}$ Edition. Lanham, MD.

MacRae, Heather/Weiner, Elaine (Eds.), 2017: Towards Gendering Institutionalism: Equality in Europe. London.

McKay, Joanna, 2004: Women in German Politics: Still Jobs for the Boys? In: German Politics. 13 (1), 56-80.

Meiritz, Annett, 2012: Frauen bei den Piraten: Allein unter gottgleichen Alpha Jungs. Spiegel Online, 8.3.2012. Internet: http://www.spiegel.de/politik/deutschland/frauen-bei-den-piratenallein-unter-gottgleichen-alpha-jungs-a-819826.html. 
Niedermayer, Oskar, 2016: Parteimitglieder in Deutschland: Version 2016. Arbeitshefte aus dem Otto-Stammer-Zentrum, Nr. 26. Berlin.

Norris, Pippa/Lovenduski, Joni, 1993: If Only More Candidates Came Forward: Supply-Side Explanations of Candidate Selection in Britain. In: British Journal of Political Science. 23 (3), $373-$ 408.

Ohmura, Tamaki/Bailer, Stefanie/Meissner, Peter/Selb, Peter, 2018: Party Animals, Career Changers, and Other Pathways into Parliament. In: West European Politics. 41 (1), 169-185.

Piscopo, Jennifer M., 2017: The Limits of Leaning In: Ambition, Recruitment, and Candidate Training in Comparative Perspective, Paper Presented at the 'Good Reasons to Run' Conference, Philadelphia, 11 November.

Preece, Jessica/Stoddard, Olga, 2015: Why Women Don't Run: Experimental Evidence on Gender Differences in Political Competition Aversion. In: Journal of Economic Behavior \& Organization. (117), 296-308.

Schulte, Ulrich, 2013: Ohne Gegenwehr endet es nicht. In: taz, 29.1.13.

SPD Berlin, 2018: Mehr Frauen in die Berliner SPD - Warum eigentlich? Internet: https://www. spd.berlin/mitmachen/mehr-frauen-in-die-spd/mehr-frauen-in-die-berliner-spd-warum-eigentlich/ (13.6.18).

Westle, Bettina, 2009: Die unpolitische Frau - ein Methodenartefakt der Umfrageforschung? In: Kühnel, Steffen/Niedermayer, Oskar/Westle, Bettina (Eds.): Wähler in Deutschland. Wiesbaden, 179-201.

Wolbrecht, Christina/Campbell, David E., 2007. Leading by Example: Female Members of Parliament as Role Models. In: American Journal of Political Science. 51 (4), 921-939.

\title{
Muslimische Politikerinnen in Deutschland: Erfolgsmuster und Hindernisse politischer Repräsentation
}

\author{
ANNE JENICHEN
}

\section{Einleitung}

In westlichen Debatten über den Islam werden muslimische Frauen meist als passive Opfer männlicher Unterdrückung porträtiert (Dhamoon 2009; Ehrkamp 2010). Politisch aktive Musliminnen kommen hingegen kaum vor, weshalb sich der vorliegende Beitrag mit genau dieser Gruppe beschäftigt.

In der deutschen Politik gibt es bisher nur wenige muslimische PolitikerInnen. Im Bundestag hat ihr Anteil in den letzten Legislaturperioden zwar kontinuierlich zugenommen, liegt aber weiterhin unter ihrem Anteil an der Gesamtbevölkerung (Hughes 2016). ${ }^{1}$ Im 19. Bundestag sind etwa $1,3 \%$ der Abgeordneten muslimischen Glaubens (sechs Frauen, drei Männer) ${ }^{2}$, während ihr Anteil an der Gesamtbevölkerung auf 5,45,7\% geschätzt wird (BAMF 2016). Angesichts dieser quantitativen Unterrepräsentanz geht der Beitrag vor allem zwei Fragen nach: Welche Hindernisse erschweren 
es muslimischen Frauen, eine politische Karriere einzuschlagen? Welche Faktoren helfen ihnen, dieses Anliegen zu verwirklichen? Dabei stellt sich auch die Frage, ob Musliminnen, als Frauen und Mitglieder einer religiösen Minderheit, doppelter Benachteiligung unterworfen sind, oder ob es im Kontext politischer Repräsentation als Mitglied einer religiösen Minderheit vielleicht sogar von Vorteil ist, weiblich zu sein. Der höhere Anteil muslimischer Frauen gegenüber muslimischen Männern im Deutschen Bundestag scheint darauf hinzuweisen.

Der Beitrag nimmt eine intersektionale Perspektive auf politische Repräsentation ein. Demnach interagieren verschiedene Aspekte der Identität, also z.B. Geschlecht und Religion, in multiplen Formen der Diskriminierung und Privilegierung miteinander (z.B. Mügge/Erzeel 2016; Weldon 2006). Obwohl insgesamt noch eine eher neue Perspektive, liegen auch zu Deutschland erste entsprechende Ergebnisse vor, die wichtige Informationen zur politischen Repräsentation von Frauen mit Migrationshintergrund bieten (Donovan 2013; Hossain et al. 2016; Markowis 2015). Allerdings legt keine dieser Studien ein besonderes Augenmerk auf Religion. ${ }^{3}$ Angesichts zunehmender anti-islamischer Ressentiments (Bertelsmann Stiftung 2015) kann jedoch vermutet werden, dass gerade für muslimische Politikerinnen das gruppenspezifische Diskriminierungspotential besonders hoch ist. Sie wurden deshalb für die folgende Studie ausgewählt, nicht nur um die Bedeutung von Religion für die Forschung zur Repräsentation von Frauen mit Migrationshintergrund einzuschätzen, sondern auch um Stereotypen zu begegnen und Möglichkeiten zur Förderung ihrer Repräsentation zu identifizieren.

Bei dem vorliegenden Beitrag handelt es sich um eine explorative Studie ohne repräsentativen Anspruch. Sie stützt sich vor allem auf qualitative Interviews mit muslimischen Politikerinnen, um aus ihren Erfahrungen Hindernisse und förderliche Faktoren für die politische Repräsentation muslimischer Frauen in Deutschland herauszuarbeiten. Die elf interviewten Politikerinnen wurden über Internetrecherchen und das Schneeballprinzip identifiziert und zu ihrer politischen Biographie befragt. Sie repräsentieren unterschiedliche Parteien (CDU, SPD, Grüne und Linke) und haben neben Parteiämtern, mit Ausnahme von zweien, alle Mandate in der (west-) deutschen Lokal-, Landes- oder Bundespolitik inne. Sie identifizieren sich selbst als Musliminnen (einige sind Sunnitinnen, andere Alevitinnen), mit stark variierendem Grad an Religiosität; zwei von ihnen tragen Kopftuch. Mit Ausnahme einer Konvertitin haben alle einen, mehrheitlich türkischen, Migrationshintergrund. ${ }^{4}$

Im Folgenden lege ich zunächst den Analyserahmen der Studie dar, bevor ich die Ergebnisse vorstelle und im Fazit weiteren Forschungsbedarf sowie politische Implikationen diskutiere.

\section{Analyserahmen: Politische Repräsentation muslimischer Frauen}

In der vorliegenden Studie geht es vor allem um die Faktoren, die die deskriptive Repräsentation muslimischer Frauen, also ihre quantitative Präsenz, in der deutschen 
Politik beeinflussen. ${ }^{5}$ Diese Faktoren lassen sich in zwei Dimensionen bzw. in drei Phasen einteilen: Auf der Angebotsseite geht es um die Entscheidung zum parteipolitischen Engagement (1. Phase), die das Angebot an potentiellen Kandidatinnen bestimmt; auf der Nachfrageseite geht es zum einen um die Selektion von Kandidatinnen durch Parteien (2. Phase), zum anderen um die eigentliche Wahl durch die Wählerschaft (3. Phase) (Norris/Lovenduski 1995; Krook/Norris 2014, 6f.). Jeder dieser drei Phasen können verschiedene Faktoren zugeordnet werden, die die politische Repräsentation benachteiligter Gruppen beeinflussen und in der Literatur zur politischen Repräsentation von Frauen (z.B. Krook/Norris 2014), von ethnischen Minderheiten und ImmigrantInnen der ersten und zweiten Generation (Bird/Saalfeld/Wüst 2011; Bloemraad/Schönwälder 2013) sowie aus dezidiert intersektionaler Perspektive (Mügge/Erzeel 2016) in ähnlicher Weise diskutiert werden:

In der ersten Phase, der Entscheidung zu parteipolitischem Engagement (,Angebotsseite"), sind vor allem die soziostrukturellen Bedingungen wichtig, die die Größe des potentiellen Kandidatinnenpools beeinflussen. Dazu gehört der Zugang zu für politische Partizipation entscheidende Ressourcen wie Bildung und politisches Wissen, Einkommen und Zeit, aber auch Wahlrecht und Sprachkenntnisse, sowie Einbindung in private und politische Netzwerke, die notwendige Unterstützung leisten bzw. für Sichtbarkeit sorgen (Bloemraad/Schönwälder 2013, 568; Krook/Norris 2014, 4f.; Mügge/Erzeel 2016, 502f.). Hinsichtlich der politischen Unterrepräsentation von Musliminnen in der deutschen Politik wäre demnach zu erwarten, dass muslimische Frauen weniger Zugang zu diesen entscheidenden Ressourcen und Netzwerken haben, was dazu führt, dass ihnen das Recht, die Kenntnisse, das Geld und die Zeit sowie die private und öffentliche Unterstützung für politisches Engagement fehlen. Es ließe sich eine doppelte soziokulturelle Benachteiligung erwarten: aufgrund des Geschlechts sowie des Migrationshintergrunds bzw. der religiösen Zugehörigkeit. Ein spezifischer Erklärungsfaktor könnten vorherrschende kulturelle Einstellungen hinsichtlich der Rolle von Frauen innerhalb muslimischer Gemeinschaften sein, wenn diese zu einer traditionellen Rollenzuweisung führen, also die Sozialisation und Abkömmlichkeit muslimischer Frauen auf eine Art beeinflussen, die vielen von ihnen die politische Karriere als nicht erstrebenswert oder praktisch unmöglich erscheinen lassen. Da diese Fragen mittels qualitativer Interviews nicht ausreichend geklärt werden können, greife ich zusätzlich auf soziostrukturelle und -kulturelle Daten zu MuslimInnen in Deutschland zurück, die neben den Interviews erste Rückschlüsse auf die Angebotsseite zulassen.

In der zweiten Phase, der Nachfrage nach Kandidatinnen durch Parteien, geht es vor allem um die Rolle der Parteien als „Gatekeeper“, die im deutschen politischen System aufgrund ihrer Monopolstellung bei der KandidatInnenauswahl besonders ausgeprägt ist (vgl. Davidson-Schmich in diesem Heft). Die Nachfrage der Parteien nach bestimmten KandidatInnen kann muslimische Frauen benachteiligen, wenn diese von (männlichen bzw. nicht-muslimischen) EntscheidungsträgerInnen innerhalb der Parteien bei der Vergabe von Ämtern und Listenplätzen bewusst diskri- 
miniert werden. Andersherum erleichtern innerparteiliche Quotenregelungen den Zugang. Eine zentrale Frage ist demnach, wie innerparteiliche Diskriminierungspraktiken mit der Existenz von Quoten interagieren. Erhalten muslimische Frauen Förderung und Vertrauen innerhalb ihrer Parteien und können von der Frauenquote profitieren? Oder wird ihnen dies aufgrund innerparteilicher Diskriminierung eher erschwert? Mit anderen Worten: Unterliegen muslimische Frauen im deutschen politischen System einer doppelten Diskriminierung durch Parteien als Frauen und Musliminnen („,double jeopardy“) oder erweist sich die Kombination von weiblichem Geschlecht und religiöser Minderheit als kumulativer Vorteil (,multiple advantage“) (Mügge/Erzeel 2016)? Auch wenn diese Frage durch qualitative Interviews mit muslimischen Politikerinnen nicht abschließend geklärt werden kann, bieten die Interviews aufschlussreiche Hinweise auf den Umgang von Parteien mit muslimischen Politikerinnen.

Die Nachfrage nach Volksvertreterinnen wird schließlich auch durch das Verhalten der WählerInnen beeinflusst. Vorbehalte gegenüber Frauen und MuslimInnen in politischen Ämtern können sich negativ auf deren Wahlerfolg auswirken, was insbesondere durch personenbezogene Komponenten in Wahlsystemen zum Tragen kommt. Studien haben gezeigt, dass Frauen allgemein, was Musliminnen einschließt, bessere Wahlchancen in Systemen mit Verhältniswahlrecht haben (Hughes 2016), weil sich WählerInnen nicht für eine einzelne Person entscheiden müssen, sondern eine Parteiliste, die mehrere KandidatInnen enthält, wählen. Auch wenn Fragen zu wahlrechtlichen Unterschieden in der vorliegenden Studie nicht beantwortet werden können, geben die Interviews Aufschluss über Diskriminierungserfahrungen muslimischer Politikerinnen in Wahlkämpfen.

\section{Erfolgsbedingungen und Hindernisse aus Sicht muslimischer Politikerinnen}

Im Folgenden stelle ich die empirischen Ergebnisse der Studie vor. Dabei werden die Ergebnisse der Interviews mit muslimischen Politikerinnen ausgewählten Befunden aus der Sekundärliteratur zur politischen Repräsentation von Frauen im Allgemeinen und von BürgerInnen mit Migrationshintergrund in Deutschland im Besonderen gegenübergestellt und gegebenenfalls durch weitere Quellen ergänzt.

\section{„Angebotseite“ politischer Repräsentation: Kandidatinnenpool}

Die Biographien der interviewten muslimischen Politikerinnen bestätigen die bedeutende Rolle von Bildung, politiknahen Berufen und ehrenamtlichen Führungspositionen sowie geschlechtergerechter Sozialisation und Arbeitsteilung für die politische Partizipation von Frauen (vgl. z.B. Kinzig 2007). Bis auf eine haben alle der interviewten Politikerinnen einen Hochschulabschluss, teilweise in politiknahen Fächern wie Jura, Politik- oder Verwaltungswissenschaft. Viele haben in politiknahen Berufen gearbeitet oder ehrenamtliche Führungserfahrungen gesammelt, z.B. 
als wissenschaftliche Mitarbeiterinnen von Abgeordneten, als Referentin in einem Ministerium, städtische Integrationsbeauftragte, Leiterin eines Integrationsprojekts oder als gewählte Mitglieder von Ausländerbeiräten. Es kann davon ausgegangen werden, dass dies ihre Sichtbarkeit erhöht und ihnen den Zugang zu politischen Netzwerken erleichtert hat.

Ihre politische Sozialisation hat für viele bereits im Elternhaus begonnen, vor allem mit gesellschaftspolitisch aktiven Vätern, aber auch Müttern und Großmüttern, die sich - teilweise bereits im Herkunftsland - engagiert haben und als Vorbilder fungierten und auch aktiv zum Engagement ermutigten. Nur eine der Interviewten berichtet über familiären Druck in ihrer Jugend durch männliche Verwandtschaft. Dieser richtete sich gegen ihren Wunsch zu studieren, der ihr als Mädchen verweigert wurde, weil damit der Wegzug vom familiären Wohnort einhergegangen wäre. Ansonsten wird familiäre Unterstützung, insbesondere später durch Lebenspartner, als wichtig betont, zum einen als emotionale Stütze, aber vor allem um mit der hohen zeitlichen Belastung eines Amtes oder Mandats neben Familie und Beruf umgehen zu können. So führen einige der interviewten Frauen auch die Verantwortung für jüngere Kinder als einen Grund an, warum sie - momentan oder in der Vergangenheit - kein höheres Mandat anstreben bzw. angestrebt haben. Gleichzeitig gibt es auch in der Gruppe muslimischer Politikerinnen, ebenso wie unter Politikerinnen ohne Migrationshintergrund, alleinstehende und/oder kinderlose Frauen, die damit zeitlich wesentlich flexibler sind.

Trotz zunehmender Pluralisierung von Rollenbildern in Deutschland gilt geschlechtsspezifische Arbeitsteilung als ein wichtiger Faktor, der die politische Repräsentation von Frauen negativ beeinflusst (Kinzig 2007). Zum Beispiel sind Frauen aufgrund geringerer Zeitbudgets Männern gegenüber oft bei der Vergabe von ehrenamtlichen Führungspositionen innerhalb lokaler Parteiorganisationen benachteiligt (Holtkamp/Schnittke/Wiechmann 2011, 46). Diese Funktionen sind jedoch als Sprungbrett für die politische Karriere sowie für die innerparteiliche Entscheidungsfindung hinsichtlich der Nominierung von KandidatInnen für Ämter und Mandate von zentraler Bedeutung. Innerhalb muslimischer Einwandererhaushalte ist häufig nicht nur die Anzahl der Kinder größer, sondern sind auch traditionelle Rollenbilder, denen zufolge Frauen für den Haushalt und die Familie zuständig sind, verbreiteter als in christlich geprägten Einwandererfamilien bzw. einheimisch-deutschen Haushalten (BAMF 2014; Diehl/Koenig/Ruckdeschel 2009). Hier liegt die Annahme nahe, dass dies eine weitere Beschränkung des potentiellen Kandidatinnenpools unter Musliminnen darstellt. Allerdings hat die Studie des Bundesamts für Migration und Flüchtlinge (BAMF 2014) auch gezeigt, dass in der zweiten Generation bereits eine deutliche Ablösung vom klassischen Rollenmodell stattfindet und bei einem hohen Bildungsabschluss die Wahrscheinlichkeit der gerechteren Aufteilung von Familienaufgaben auch unter MuslimInnen zunimmt.

Die Erfolgsfaktoren Bildung, politiknahe Berufe und ehrenamtliche Führungspositionen sowie geschlechtergerechte Sozialisation und Arbeitsteilung sind demnach 
wichtig für die politische Karriere von Frauen sowohl ohne als auch mit Migrationshintergrund. Allerdings ist die Gruppe mit Migrationshintergrund mit weiteren und spezifischen Hindernissen konfrontiert (vgl. auch Hossain et al. 2016; Markowis 2015).

Ein zentrales Hindernis ist der beschränkte Zugang zur deutschen Staatsbürgerschaft. Zwar ist der Pool potentieller KandidatInnen mit Migrationshintergrund (unabhängig von ihrem Glauben) seit der Liberalisierung des Einbürgerungsrechts im Jahr 2000 stark angewachsen auf etwa 10\% aller Wahlberechtigten in Deutschland (Mediendienst Integration o.J.); allerdings sind Schätzungen nach nur etwa 1,5 Millionen der in Deutschland lebenden MuslimInnen wahlberechtigt (Deutsche Welle 2017). Gehen wir davon aus, dass etwa die Hälfte davon Frauen sind, dann ist der Pool potentieller Kandidatinnen schon massiv geschrumpft; und er wird weiter beschränkt durch bestehende sozio-ökonomische Benachteiligung von Migrantinnen sowohl im Bildungssystem als auch auf dem Arbeitsmarkt (Hipp 2016; Hummitzsch 2014). So haben z.B. von den Muslim Innen, die in Deutschland leben und zur Schule gegangen sind, laut einer Studie des BAMF $(2009,211)$, ca. 30\% die Hochschulreife erlangt, allerdings ist dies bei Frauen (25,6\%) weniger der Fall als bei Männern (34\%). Gleichzeitig ist der Anteil derjenigen, die über gar keinen oder nur einen Hauptschulabschluss verfügen, sehr hoch - insbesondere unter den Frauen (41,5\% im Vergleich zu 36,4\% der Männer).

Gesellschaftliche Ausgrenzung, oder wie es eine der Politikerinnen im Interview formulierte, „die Erfahrung, Minderheit zu sein in der Mehrheitsgesellschaft“ (Interview 3), beeinflusst nicht nur die Bildungs- und Berufserfolge von ZuwandererInnen, sondern auch die Bereitschaft sich politisch zu engagieren. Alle interviewten Politikerinnen mit Migrationshintergrund berichten von Diskriminierungserfahrungen in der Schul- und Studienzeit sowie bei der Job- und Wohnungssuche. Bis heute haben einige der Politikerinnen das Gefühl, dass sie sich ganz besonders beweisen müssen, weil ihnen als Frauen mit Migrationshintergrund erst einmal weniger zugetraut wird. Wie eine der Interviewten betont: „Ich kämpfe jeden Tag von Neuem dagegen an, auf meine Herkunft reduziert zu werden“ (Interview 1). Diese Ungleichbehandlung wurde für viele von ihnen zu einer wichtigen Motivation, sich gesellschaftlich zu engagieren. Gleichzeitig kann sie jedoch, wie einige der Interviewten betonen, auch abschrecken und zum Rückzug in die Privatsphäre beitragen.

Religion spielt in diesem Kontext eine zentrale Rolle, zum einen erlangt sie Bedeutung als etwas, was in Form von Diskriminierung und Stereotypen von außen an die Politikerinnen herangetragen wird, zum anderen als ihr eigener Glaube sowie ihre Überzeugungen und Handlungen, die sich aus diesem ergeben. Einige der interviewten Politikerinnen sehen sich regelmäßig mit Stereotypen über muslimische Frauen konfrontiert, fühlen sich als Frauen mit (türkischem) Migrationshintergrund auf ihre Religion reduziert (selbst wenn sie diese gar nicht nach außen kommunizieren) und berichten über entsprechende Ausgrenzungserfahrungen. In den meisten Interviews finden die immer wieder aufkommenden, stereotyp geführten politischen Debatten 
über den Islam und über MuslimInnen in Deutschland sowie das Aufkommen islamophober Bewegungen und Parteien, wie Pegida und Alternative für Deutschland, frustrierte Erwähnung, die auch als ein möglicher Grund dafür angesehen werden, dass sich viele MuslimInnen eher zurückziehen statt sich in deutschen Parteien zu engagieren. Gleichzeitig sehen sich viele der interviewten Politikerinnen durch diese Entwicklungen gezwungen, aktiv Vorurteilen und Pauschalisierungen entgegenzutreten. Hinsichtlich des eigenen Glaubens und dessen politischer Bedeutung lassen sich die interviewten Politikerinnen in zwei Gruppen einteilen. Für einen Teil der interviewten muslimischen Politikerinnen selbst spielt ihre Religion fast ausschließlich eine persönliche, in ihrem politischen Werdegang aber eher untergeordnete Rolle: „Für mich ist Religion Privatsache“ (Interview 11), wie eine der Interviewten stellvertretend für andere betont. Einige dieser Politikerinnen pflegen Kontakte zu muslimischen bzw. alevitischen Gemeinden, die vor allem privater Natur sind, aber manche setzen sich auch politisch für ihre Unterstützung, manchmal auch für mehr Geschlechtergerechtigkeit innerhalb dieser ein; andere haben gar keine Kontakte. Grundsätzlich ist Religion für sie jedoch kein zentrales Thema in ihrer politischen Karriere. Die andere Gruppe hingegen setzt sich aktiv für die Gleichstellung des Islams ein und unterhält politische Kontakte zu verschiedenen Moscheegemeinden und muslimischen Organisationen. Auch wenn die Ergebnisse hier nicht repräsentativ für alle muslimischen Politikerinnen in Deutschland stehen können, so deutet die Verteilung der elf interviewten Politikerinnen verschiedener politischer Ebenen auf die beiden Gruppen darauf hin, dass die erste Gruppe es leichter hat bis auf die Bundesebene vorzudringen, während Mitglieder der zweiten Gruppe sich eher auf kommunalpolitischer Ebene bewegen. Dies lässt erste Schlüsse darauf zu, dass Parteien einen bestimmten Typ muslimischer Politikerinnen bevorzugen, worauf im nächsten Abschnitt noch näher eingegangen wird.

Zusammenfassend lässt sich konstatieren, dass der muslimische Kandidatinnenpool aufgrund staatsbürgerschaftlicher Beschränkungen, sozio-ökonomischer Benachteiligung und gesellschaftlicher Ausgrenzung noch einmal geringer ausfällt als derjenige von Kandidatinnen ohne Migrationshintergrund. Bei letzteren ist das Argument sicherlich richtig, dass aufgrund zunehmender, wenn auch im Hinblick auf familiäre Arbeitsteilung sicherlich noch lange nicht erreichter Gleichstellung zwischen den Geschlechtern politische Unterrepräsentation von Frauen kaum mehr damit begründet werden kann, dass nicht genügend Frauen zur Auswahl stünden (Kinzig 2007). Selbst im Fall von Kandidatinnen mit Migrationshintergrund ist der Pool inzwischen ausreichend groß (Hossain et al. 2016, 78f.). Nicht alle Menschen mit Migrationshintergrund sind jedoch muslimisch. So ist im Fall muslimischer Frauen das Argument eines begrenzten „Angebots“ an Kandidatinnen nicht völlig von der Hand zu weisen. Allerdings sind auch weniger muslimische Politikerinnen notwendig, um eine angemessene deskriptive Repräsentation zu erzielen. Warum dies nicht gelingt, wird deutlich, wenn man die „Nachfrage“ durch Parteien und WählerInnen genauer in den Blick nimmt. 
„Nachfrage“ durch Parteien und WählerInnen

Forschung zu Frauen ohne und mit Migrationshintergrund in der deutschen Politik hat die Diskriminierung durch Parteien als zentralen Faktor für ihre Unterrepräsentanz identifiziert. CDU/CSU und SPD nominieren weniger Frauen als Männer für aussichtsreiche Direktmandate, was eine zentrale Erklärung dafür ist, dass - trotz Frauenquote - der Frauenanteil stagniert (Davidson-Schmich/Kürschner 2011; Holtkamp/Schnittke/Wiechmann 2011).Zudem vergeben auf kommunalpolitischer Ebene alle Parteien, mit Ausnahme der Grünen, durchschnittlich schlechtere Listenplätze an KandidatInnen mit Migrationshintergrund (Hossain et al. 2016, 178ff.). Auch wenn diese Praxis auf bundespolitischer Ebene nicht mehr ersichtlich ist (Wüst 2014), behindert sie die politische Repräsentation von KandidatInnen mit Migrationshintergrund, da der Einstieg in eine politische Karriere meist über die lokale Ebene erfolgt. Gleichzeitig wird diese Diskriminierung durch Parteien kaum thematisiert, was, wie Hossain et al. $(2016,149)$ betonen, zur „Reproduktion gesellschaftlicher, männlich dominierter Herrschaftsverhältnisse" beiträgt. Auch in meinen Interviews gibt es nur wenige Hinweise darauf, dass muslimische Politikerinnen Diskriminierung durch Parteieliten wahrnehmen. Im Gegenteil, die meisten fühlen sich eher unterstützt, auch diejenigen, die etwa bei der letzten Bundestagswahl 2017 kein Mandat erlangt haben. Einige wenige, vor allem diejenigen aus der religionspolitisch aktiven Gruppe, äußern jedoch auch Kritik, die sich zum Teil auf eigene Erfahrungen, zum Teil auf Beobachtungen stützt. So berichten die beiden mandatslosen Politikerinnen über lokale innerparteiliche Mobilisierung, z.B. mittels Telefonkampagnen, gegen die Nominierung von KandidatInnen, deren religionspolitische Positionen oder offensichtlicher muslimischer Hintergrund auf Widerstand gestoßen sind. Einige bemerken, dass ihre Parteien immer wieder daran erinnert werden müssen, ihre Listen vielfältig zu gestalten, ansonsten passiere das nicht, und kritisieren die Diskriminierung von KandidatInnen mit noch nicht perfekten Deutschkenntnissen. Ansonsten bezieht sich die Kritik weniger auf den Nominierungsprozess als auf den Zugang zu lokalen Parteiorganisationen und auf den Umgang mit PolitikerInnen mit Migrationshintergrund, sind diese erst einmal gewählt. Während ersterer bei den kleinen Parteien aufgrund der Offenheit der Strukturen sich einfacher gestalte, sei der Zugang zu Ortsvereinen der großen Parteien häufig schwierig. Als förderlich erweist sich in den Interviews persönlicher Kontakt, z.B. durch FreundInnen oder über vorheriges ehrenamtliches Engagement in anderen, häufig migrantisch geprägten Kontexten und persönliche Ansprache sowie eine gewisse Willkommenskultur von Seiten des Ortsverbands. Auch eine gewisse interkulturelle Sensibilität, dass z.B. nicht ausschließlich Schweinefleisch auf Veranstaltungen angeboten oder über die Maßen Alkohol bei abendlichen Treffen konsumiert werde, betont eine Interviewte als wichtig, um interessierte MuslimInnen nicht sofort wieder abzuschrecken. Wenn hingegen Vorbehalte gegenüber MigrantInnen und MuslimInnen bereits im Ortsverband deutlich werden, ist es äußerst schwierig, Zugang zur Partei und zu den für eine politische Karriere so wichtigen informellen 
Netzwerken zu finden. Solche Vorbehalte finden sich laut der Interviewten in allen Parteien wieder und äußern sich in Stereotypen, die an sie herangetragen werden, oder auch in Unterstellungen, dass sie etwa aufgrund ihres religiösen Hintergrunds bestimmte Themen, wie die staatliche Anerkennung muslimischer Gemeinden oder das Kopftuch, nicht distanziert genug betrachten könnten bzw. dass sie zu wenig politische Distanz zu bestimmten muslimischen Organisationen wahren würden. Gerade die Zusammenarbeit mit muslimischen Gemeinden und Organisationen ist für einige der interviewten Politikerinnen eine „extreme Gratwanderung“; insbesondere wenn sie auch mit Mitgliedern traditionellerer Vereine sprechen, werden sie schnell zur „Zielscheibe“ anderer PolitikerInnen und der Medien, was die eigentliche politische Arbeit stark behindere (Interview 9). Darüber hinaus geben die Interviews jedoch wenig Hinweise auf eine durchgängige Diskriminierung muslimischer Politikerinnen innerhalb der Parteien. Trotz Vorbehalten, die ihnen auch innerhalb ihrer eigenen Parteien immer wieder begegnen, finden sie doch auch ausreichend Unterstützung, um sich z.B. gegen Mitbewerberinnen durchzusetzen.

In der Repräsentationsforschung aus intersektionaler Perspektive ist eine zentrale Frage, inwieweit Frauen mit Migrationshintergrund von Quoten profitieren (Celis et al. 2014). Für Deutschland gibt es deutliche Hinweise darauf, dass in den meisten Parteien neben der institutionalisierten Frauenquote auch eine inoffizielle MigrantInnenquote besteht. Es gibt Belege dafür, dass Parteien gezielt Frauen mit Migrationshintergrund rekrutieren, da dies beide Quoten gleichzeitig befriedigt (Donovan 2013, 35; Hossain et al. 2016, 182ff.; Markowis 2015; Wüst 2014). Auch einige der muslimischen Bundespolitikerinnen, insbesondere von den Grünen und der Linken, berichten über so eine „Mehrfachquote“ (Interview 1), von der sie in Nominierungsprozessen profitiert hätten. Fast alle Interviewten, die ein Mandat auf Bundes-, Landes- oder Kommunalebene innehaben, sind gezielt gefördert worden, indem sie angesprochen wurden, ob sie der Partei beitreten, Ämter übernehmen oder für Mandate kandidieren wollen, häufig ohne die ansonsten notwendige langjährige Erfahrung in den Parteistrukturen mitzubringen.

Auch wenn diese gezielte Förderung für die betroffenen Politikerinnen erst einmal positiv zu bewerten ist, führt sie insgesamt nicht unbedingt zu mehr Chancengleichheit. „Denn wenn zwei Quoten durch die Listenplatzierung mit nur einer Person erfüllt werden, stehen schließlich mehr Plätze für Männer ohne Migrationshintergrund zur Verfügung“ (Hossain et al. 2016, 185). Die gezielte Rekrutierung erlaubt es den Parteien zum einen zu zeigen, dass sie auf gesellschaftliche Forderungen nach mehr Gleichstellung und Vielfalt reagieren, zum anderen, ihre „Gatekeeper“-Funktion zu erhalten. Sie wählen selber aus, welche Frauen sie fördern. Dies kann zur Folge haben, dass nur bestimmte Gruppen zum Zuge kommen und ist eine mögliche Erklärung dafür, dass auf Bundes- und Länderebene hauptsächlich muslimische Frauen repräsentiert sind, die ihre Religion als Privatsache ansehen und soweit wie möglich aus der Politik heraushalten, also dem Bild der „Vorzeige-Muslimin“, die „,modern, säkular und progressiv“ ist (Dhamoon 2009, 137) entsprechen. 
Eine ähnlich zwiespältige Dynamik lässt sich für den WählerInnenmarkt feststellen. Einerseits lassen sich, mit Ausnahme des rechten Spektrums, nicht länger Hinweise auf eine durchgängige Diskriminierung von KandidatInnen mit Migrationshintergrund finden (Hossain et al. 2016, 192f.; Street 2014). Einige der interviewten muslimischen Politikerinnen berichten zwar von Anfeindungen in Wahlkämpfen, bewerten diese jedoch eher als Minderheitenmeinung. Zudem kommen diese eher aus dem deutsch-nationalen/rechten sowie, vor allem gegenüber alevitischen Politikerinnen, aus dem türkisch-nationalistischen Lager, also von Gruppen, welche die Parteien der Interviewten eher nicht wählen würden. Andererseits äußerten einige der Interviewpartnerinnen die Vermutung, dass sie wenig offenen Anfeindungen ausgesetzt seien, weil man ihnen ihren Migrationshintergrund und ihre Religionszugehörigkeit weder äußerlich ansehen noch an einem Akzent anhören könne. Einige verwiesen in diesem Zusammenhang auch auf das Kopftuch und äußerten die Vorstellung, dass ihnen unter Umständen mehr Vorbehalte begegneten, wenn sie ein solches tragen würden. Möglicherweise erklärt dies, warum es bisher nur in der Lokalpolitik einige wenige Kopftuch tragende Politikerinnen gibt, noch nicht jedoch in der Bundes- und Landespolitik. Aufschlussreich ist in diesem Zusammenhang die Aussage einer der interviewten, Kopftuch tragenden Lokalpolitikerinnen, die verriet, dass sie im Wahlkampf für die Kommunalwahlen „,das sehr geschickt gemacht“ hätten; sie haben „keine Plakate aufgehangen von mir. (...) Deshalb hatten wir wenig Gegenwind“ (Interview 8). Dies weist darauf hin, dass Parteien sehr wohl noch Vorbehalte gegen MuslimInnen durch WählerInnen antizipieren.

\section{Fazit}

Musliminnen sind in der deutschen Politik unterrepräsentiert. Aus der Analyse lässt sich die Hypothese ableiten, dass dies an der Kombination des eingeschränkten Kandidatinnenpools in Kombination mit den noch unzureichenden Bemühungen der Parteien, für eine gleichberechtigte Repräsentation zu sorgen, liegt; letzteres auch angesichts antizipierter, möglicher Vorbehalte in der Wahlbevölkerung gegen MuslimInnen in der Politik. Die De-Thematisierung von Barrieren sowie die ambivalente Wirkung der inoffiziellen „Mehrfachquote“ trägt ebenfalls dazu bei, dass muslimische Politikerinnen weiterhin unterrepräsentiert sind. Die Erfolgsbedingungen (Hochschulabschluss, berufliche/ehrenamtliche Vorerfahrung, verfügbare Zeit und familiäre Unterstützung bzw. Ungebundenheit, gezielte Förderung durch Parteieliten) und entsprechende Hindernisse (traditionelle Geschlechterrollen, gesellschaftliche Benachteiligung und Ausgrenzung, Vorbehalte in den Parteien und - antizipiert - in der WählerInnenschaft) für die politische Karriere sind denen von Frauen mit Migrationshintergrund sehr ähnlich (vgl. v.a. Hossain et al. 2016; Markowis 2015). Dies ist wenig verwunderlich, da Musliminnen in der Regel einen Migrationshintergrund haben. Allerdings zeigen die Interviews auch, dass Religion, und spezifisch der Islam, eine Kategorie ist, die - zumindest heutzutage - viele dieser 
Ausgrenzungserfahrungen noch einmal verstärkt, insbesondere wenn es um sichtbare Symbole wie das Kopftuch geht. Zudem liegt sie quer zur Kategorie Migrationshintergrund. So gibt es in den Parteien des eher linken Spektrums (SPD, Grüne, Linke) viele PolitikerInnen sowohl mit als auch ohne Migrationshintergrund, die nicht religiös und eher säkular eingestellt sind. Muslimische Politikerinnen, die sich für mehr Dialog mit Religionsgemeinschaften und für die Anerkennung einer öffentlichen Rolle von Religion aussprechen, ecken dort schnell an. Dies ist auch eine Erklärung dafür, warum der Aufstieg für Musliminnen, die ihre Religion als Privatsache verstehen, in diesen Parteien bisher leichter zu sein scheint. ${ }^{6}$ In der CDU stellt sich die Situation ein bisschen anders dar. Dort ist die Anerkennung für eine öffentliche Rolle von Religion weitestgehend gegeben - einer der Gründe, warum die Partei trotz des ,großen C“ attraktiv für gläubige MuslimInnen ist (Mumme 2016). Die Akzeptanz des Islams und die Integration von MuslimInnen hingegen ist umstritten, was es für muslimische Politikerinnen, die sich für genau diese Fragen einsetzen, schwieriger macht, sich gegen Vorbehalte durchzusetzen.

Aufgrund der geringen Fallzahl können die Interviews nur eine erste Annäherung an das Thema bieten. Sie weisen jedoch darauf hin, dass Religion gesondert von Migrationshintergrund zu betrachten ist, wenn Hindernisse, insbesondere für sichtbare Minderheiten, in der Politik genauer erfasst werden sollen. Mehr Forschung ist jedoch notwendig, die auch muslimische Politiker sowie nicht-muslimische/nichtreligiöse PolitikerInnen mit Migrationshintergrund in den Blick nimmt und weitere Quellen, wie die Analyse von Wahllisten und repräsentative Befragungen, nutzt, um diese Frage systematisch zu eruieren.

Die interviewten Politikerinnen trotzen verbreiteten Stereotypen über muslimische Frauen und nehmen eine wichtige Vorbildfunktion ein. Der Erhöhung ihres Anteils in der deutschen Politik bräuchte vor allem einen erleichterten Zugang zur deutschen Staatsbürgerschaft, zum Beispiel durch die Möglichkeit der doppelten Staatsbürgerschaft, und den Abbau sozio-ökonomischer und gesellschaftlicher Diskriminierung, um den Pool potentieller Kandidatinnen zu vergrößern. Frauen benachteiligende, traditionelle Rollenbilder und geschlechtsspezifische Arbeitsteilung hingegen gehören - unabhängig von ethnischer Herkunft und religiöser Überzeugung - bekämpft. Die Vermutung, diese Rollenbilder wären in nicht-muslimischen Haushalten in Deutschland längst überwunden, würde nicht nur die Realität verkennen, sondern auch weitere Ausgrenzung unnötig befördern. Nicht zuletzt sind die Parteien aufgerufen, sich stärker für MuslimInnen zu öffnen, wollen sie ihrem Anspruch nach mehr Vielfalt wirklich gerecht werden.

\section{Anmerkungen}

1 Hier muss jedoch bereits darauf hingewiesen werden, dass in vielen Studien (darunter auch Hughes 2016) Menschen bereits als muslimisch eingeordnet werden, wenn sie oder ihre Eltern aus einem mehrheitlich muslimischen Land stammen. Dies sehe ich als problematisch an, da nicht alle TürkInnen auch muslimischen Glaubens sind. Ich ziehe im Rahmen dieser Studie deshalb die Selbstidentifikation als muslimisch zur Abgrenzung der Gruppe vor (zur 
Problematik der Abgrenzung verschiedener Gruppen im Kontext der Messung politischer Repräsentation siehe Celis/Mügge 2018).

2 Fünf Abgeordnete bekennen sich auf ihren Bundestagswebseiten zum Islam, vier weitere habe ich durch Internetrecherchen identifiziert. Zahlen zur Landes- und Kommunalebene liegen nicht vor.

3 Arbeiten zur politischen Partizipation von Musliminnen in Deutschland beschäftigen sich kaum mit ihrer Repräsentation in der formalen Politik, sondern vor allem mit ihrem zivilgesellschaftlichen Engagement (z.B. Gamper/Reuter 2008). Wenn formale politische Repräsentation von Musliminnen untersucht wird, dann nur als Teil größerer Vergleichsstudien, die die Analyse auf den Einfluss eines einzelnen Erklärungsfaktors, z.B. das Wahlrecht, verengen (Hughes 2016).

4 Da es sich bei muslimischen Politikerinnen in Deutschland um eine sehr kleine Gruppe handelt, können hier, um die ihnen zugesicherte Anonymität zu wahren, keine genaueren Angaben gemacht werden.

5 Deskriptive Repräsentation ist von substantieller Repräsentation zu unterscheiden, die sich auf die Vertretung der spezifischen Interessen dieser präsenten Gruppen bezieht (Phillips 1995).

6 Dies geht in eine ähnliche Richtung wie die Erkenntnis, ., dass diejenigen MandatsträgerInnen mit Zuwanderungsgeschichte am erfolgreichsten in der Politik sind, die versuchen, ihren Status als .ganz normale Abgeordnete' in den Vordergrund zu rücken“" (Markowis 2015, 306).

\section{Literatur}

Bertelsmann Stiftung, 2015: Religionsmonitor. Sonderauswertung Islam 2015. Internet: https:// www.bertelsmann-stiftung.de/fileadmin/files/Projekte/51_Religionsmonitor/Zusammenfassung_der_Sonderauswertung.pdf (5.4.2018).

Bird, Karen/Saalfeld, Thomas/Wüst, Andreas M., 2011: Ethnic Diversity, Political Participation and Representation. A Theoretical Framework. In: Bird, Karen/Saalfeld, Thomas/Wüst, Andreas M. (Hg.): The Political Representation of Immigrants and Minorities. Voters, Parties and Parliaments in Liberal Democracies. London, New York, 1-21.

Bloemraad, Irene/Schönwälder, Karen, 2013: Immigrant and Ethnic Minority Representation in Europe. Conceptual Challenges and Theoretical Approaches. In: West European Politics. 36 (3), 564-579.

Bundesamt für Migration und Flüchtlinge (BAMF), 2009: Muslimisches Leben in Deutschland. Im Auftrag der Deutschen Islam Konferenz. Internet: http://www.deutsche-islam-konferenz.de/ SharedDocs/Anlagen/DIK/DE/Downloads/WissenschaftPublikationen/MLD-Vollversion.pdf? blob=publicationFile (3.2.2018).

Bundesamt für Migration und Flüchtlinge (BAMF), 2014: Geschlechterrollen bei Deutschen und Zuwanderern christlicher und muslimischer Religionszugehörigkeit. Internet: https://www.bamf. de/SharedDocs/Anlagen/DE/Publikationen/Forschungsberichte/fb21-geschlechterrollen.html (6.4.2018).

Bundesamt für Migration und Flüchtlinge (BAMF), 2016: Wie viele Muslime leben in Deutschland? Eine Hochrechnung über die Anzahl der Muslime in Deutschland zum Stand 31. Dezember 2015. Internet: https://www.bamf.de/SharedDocs/Anlagen/DE/Publikationen/WorkingPapers/ wp71-zahl-muslime-deutschland.pdf?__blob=publicationFile (3.4.2018).

Celis, Karen/Erzeel, Silvia/Mügge, Liza/Damstra, Alyt, 2014: Quotas and Intersectionality. Ethnicity and Gender in Candidate Selection. In: International Political Science Review. 35 (1), 41-54.

Celis, Karen/Mügge, Liza M., 2018: Whose Equality? Measuring Group Representation. In: Politics. 38 (2), 197-213.

Davidson-Schmich, Louise K./Kürschner, Isabelle, 2011: Stößt die Frauenquote an ihre Grenzen? Eine Untersuchung der Bundestagswahl 2009. In: Zeitschrift für Parlamentsfragen. 42 (1), 25-34.

Deutsche Welle, 2017: Bundestagswahl. Was Muslime wählen. Internet: http://www.dw.com/de/ bundestagswahl-was-muslime-w\%C3\%A4hlen/a-40490941 (3.4.2018). 
Dhamoon, Rita, 2009: Identity/Difference Politics. How Difference is Produced and Why It Matters. Vancouver, Toronto.

Diehl, Claudia/Koenig, Matthias/Ruckdeschel, Kerstin, 2009: Religiosity and Gender Equality. Comparing Natives and Muslim Migrants in Germany. In: Ethnic and Racial Studies. 32 (2), 278-301.

Donovan, Barbara, 2013: Intersectionality and the Substantive Representation of Migrant Interests in Germany. In: German Politics and Society. 30 (4), 23-44.

Ehrkamp, Patricia, 2010: The Limits of Multicultural Tolerance? Liberal Democracy and Media Portrayals of Muslim Migrant Women in Germany. In: Space and Polity. 14 (1), 13-32.

Gamper, Markus/Reuter, Julia, 2008: Muslimische Frauen-Netzwerke in Deutschland. Selbstorganisation und Interessenartikulation von Migrantinnen. In: Femina Politica. 17 (1), 81-93.

Hipp, Lena, 2016: Ungleichheiten und Diskriminierung auf dem Arbeitsmarkt. In: Aus Politik und Zeitgeschichte. 66 (9). Internet: http://www.bpb.de/apuz/221588/ungleichheiten-und-diskriminierung-auf-dem-arbeitsmarkt?p=all (6.4.2018).

Holtkamp, Lars/Schnittke, Sonja/Wiechmann, Elke, 2011: Die Stagnation der parlamentarischen Frauenrepräsentanz. Erklärungsansätze am Beispiel deutscher Großstädte. In: Zeitschrift für Parlamentsfragen. 42 (1), 35-49.

Hossain, Nina/Friedhoff, Caroline/Funder, Maria/Holtkamp, Lars/Wiechmann, Elke, 2016: Partizipation - Migration - Gender. Eine Studie über politische Partizipation und Repräsentation von Migrant_innen in Deutschland. Baden-Baden.

Hughes, Melanie M., 2016: Electoral Systems and the Legislative Representation of Muslim Ethnic Minority Women in the West, 2000-2010. In: Parliamentary Affairs. 69 (3), 548-568.

Hummitzsch, Thomas, 2014: Diskriminierung von Migranten auf dem Ausbildungs- und Arbeitsmarkt. Bundeszentrale für politische Bildung. Internet: http://www.bpb.de/gesellschaft/migration/newsletter/182169/diskriminierung-von-migranten (6.4.2018).

Kinzig, Silke, 2007: Auf dem Weg zur Macht? Zur Unterrepräsentation von Frauen im deutschen und U.S.-amerikanischen Regierungssystem. Wiesbaden.

Krook, Mona Lena/Norris, Pippa, 2014: Beyond Quotas. Strategies to Promote Gender Equality in Elected Office. In: Political Studies. 62, 2-20.

Markowis, Freya Angelika, 2015: Mandatsträgerinnen und Mandatsträger mit Migrationshintergrund. Karrierewege und substantielle Repräsentation von Landtagsabgeordneten mit Zuwanderungsgeschichte. Berlin.

Mediendienst Integration, o.J.: Politische Teilhabe. Internet: https://mediendienst-integration. de/integration/politik.html (2.4.2018).

Mügge, Liza M./Erzeel, Silvia, 2016: Double Jeopardy or Multiple Advantage? Intersectionality and Political Representation. In: Parliamentary Affairs. 69 (3), 499-511.

Mumme, Thorsten, 2016: Warum die CDU die neue Partei der Migranten ist. Internet: https:// www.welt.de/politik/deutschland/article157163316/Warum-die-CDU-die-neue-Partei-der-Migranten-ist.html (2.7.2018).

Norris, Pippa/Lovenduski, Joni, 1995: Political Recruitment. Cambridge.

Phillips, Anne, 1995: The Politics of Presence. Oxford.

Street, Alex, 2014: Representation despite Discrimination. Minority Candidates in Germany. In: Political Research Quarterly. 67 (2), 374-385.

Weldon, S. Laurel, 2006: The Structure of Intersectionality. A Comparative Politics of Gender. In: Politics \& Gender. 2 (2), 235-248.

Wüst, Andreas M., 2014: Immigration into Politics. Immigrant-origin Candidates and Their Success in the 2013 Bundestag Election. In: German Politics and Society. 32 (3), 1-15. 


\title{
The Reluctant Feminist: Angela Merkel and the Modernization of Gender Politics in Germany
}

\author{
JOYCE MARIE MUSHABEN
}

The adoption of female suffrage across multiple western nations in the early 1900s was accompanied by the expectation that women's ability to vote would eventually lead to their direct involvement in governance. It was further assumed that by boosting more of their own kind into positions of power, female suffrage could and would make a significant difference in the laws and policies being adopted, thus allowing women to shape their own lives (cf. Cress in this volume). The last 100 years have unfortunately supplied much evidence to the contrary, leading countless scholars to investigate women's irregular paths to power, the institutional barriers they face, the stereotypical role expectations that hinder their progress, and new mechanisms seeking to equalize their participation in politics (in Germany: Davidson-Schmich 2016; Kolinsky 1991; Roll 2005; Scholz 2007; Clemens 2006). ${ }^{1}$ These studies, in turn, have led us to theorize about different types of representation in an effort to explain when, where and how more women in politics might generate better, far-reaching policies for women.

Female suffrage may be a necessary condition, but it is clearly not a sufficient one in fostering gender equality. The 100th anniversary of women's right to vote in Germany (cf. Abels 2011) provides a unique opportunity to re-assess the metrics scholars use to determine whether the politicians female voters help to elect do, in fact, adopt policies enhancing the balanced participation of women and men in public life (Carless 1998; Geissel 2000). While many comparativists focus on the quantitative dimensions, known as descriptive representation (the number of women in powerful positions), few present direct evidence that female leadership has, or has not (Beckett 2006) induced qualitative reforms, labeled substantive representation. Finding empirical measures for the latter is a lot harder, insofar as many policies can take years simply to produce a level playing field, much less equitable societal outcomes. The ability to introduce gender-sensitive policies moreover depends on a wide array of structural factors, e.g. shifting party coalitions or economic crises, that cannot be held constant in real-world settings. Case studies often provide the best opportunity for establishing causal links between the presence of women in politics and adoption of better policies for women (von Wahl 2011; Wiliarty 2010; Yoder 2011). Based on a much longer study of Germany's first female Chancellor (Mushaben 2017) this brief essay analyzes the extent to which Angela Merkel has used her power to advance gender equality since 2005 . In other words: Can one woman really make a difference? I argue that despite her Christian-Democratic affiliation, Merkel has indeed done more to foster equality than all previous German chancellors combined, although she refuses to label herself a feminist.

Of course, there is no way to prove that her sex alone accounts for major policy changes; curiously, no one ever raises this question in relation to male leaders, sug- 
gesting a double standard even on the part of gender scholars. But if we are serious about recognizing intersectionality, we cannot deny that gender is a core variable in most decision-making contexts (Lombardo/Agustin 2011). Re-elected for the fourth time in 2017, Merkel has faced different coalition configurations, complicated by serious personality conflicts among her Cabinet members. Her many years in office nevertheless provide a solid foundation for observing not only changing laws but also medium-term policy outcomes. The fact that this Chancellor may have had "non-feminist" motives for introducing gender-sensitive policies does not detract from the real, everyday improvements engendered by these reforms.

I first explore key reasons hindering Merkel's public identification with feminism, which critics erroneously use to downplay her contributions to gender equality. One needs to recall that Merkel spent the first 35 years of her life under an eastern gender regime that differed significantly from the postwar Kinder-Küche-Kirche paradigm shaping West Germany through 1989. Given the long-standing conflicts among different schools of western feminism (liberal, socialist, radical-autonomous, womanist) over the years (Mushaben 1989), she would probably be "damned if she did, damned if she didn't" identify with one type over the other. I then outline legislative changes that can be ascribed to descriptive and substantive representation, respectively. I conclude with a few policies that I attribute to a third category of electoral impact, transformational representation.

\section{Playing the Feminist Card at the Women20 Summit}

Anticipating her role as president of the 2017 G-20 summit meeting, Angela Merkel tasked the Deutscher Frauenrat and the Verband Deutscher Unternehmerinnen in 2016 with organizing the Women20 (W20) Dialogue. Established under the Turkish presidency in 2015, the W20 became an official G20 "engagement group," lobbying for the inclusion of female economic empowerment world-wide. ${ }^{2}$ The purported high-point in 2017 was a Berlin panel discussion on April 25, titled "Inspiring Women: Scaling up Women's Entrepreneurship.” Participants included German Chancellor Merkel, Dutch Queen Máxima, Canadian foreign minister Chrystia Freeland, IMF director Christine Lagarde, Bank of America CEO Anne Finucane, "first daughter" Ivanka Trump, Kenian high-tech entrepreneur Juliana Rotich und Nicola Leibinger-Kammüller, CEO of Trumpf GmbH. Wirtschaftswoche publisher Miriam Meckel moderated the discussion.

Towards the end of the session, moderator Meckel asked the participants whether they considered themselves feminists. Lagarde immediately raised her hand; Trump encouraged the audience to applaud but was jeered when she finally waved hers as well. Merkel's hesitation led Meckel to ask her point-blank, "are you a feminist?" She replied hesitantly:

Ehrlich gesagt, ähm, möchte ich (...). Also, die Geschichte des Feminismus ist eine, bei der es gibt Gemeinsamkeiten mit mir, und (...) auch solche wo ich sagen würde, es gibt 
auch Unterschiede. Und ich möchte mich nicht mit einem Titel schmücken, den ich gar nicht habe (...), denn Alice Schwarzer und so, die haben ganz schwere Kämpfe gekämpft, und jetzt komm" ich und setzte mich auf die Erfolge und sage, "ich bin Feministin. Das ist aber toll (...)." Ich habe keine Angst, wenn Sie finden, dass ich eine bin - dann stimmen Sie ab (...). Aber ich möchte mich nicht mit der Feder schmücken. ${ }^{3}$

The clip went more or less viral, without anyone noticing that Leibinger-Kammüller also remained silent.

This was not the first time that Merkel had publicly refused to embrace the feminist label, even though the "World's Most Powerful Women" eleven times over has faced a never-ending barrage of sexist tributes, ranging from endless hairdo montages, a Merkel Barbie-Doll, comic books and animated dance-videos, to a Blazer Watch and pants-suit jokes (Mushaben 2017; Schramm 2016). The evening-gown she wore to the Oslo Opera House in 2008 unleashed a wave of offensive cleavagecommentaries, e.g., the UK tabloid headlines, "Merkel's Weapons of Mass Distraction" and "Deutschland boober alles" (Der Spiegel, April 14, 2008). Pundits have called her everything from Kohl's Girl, Joan of Arc, the Iron Maiden, Father-Killer, Angie the Sleeper and the Black Widow Spider, to Maggie Merkel, die Trümmerfrau, Alice in Wunderland, Mrs. Cool, the Alpha-Kanzlerin, the Power-Physicist, Merkiavelli and that all-time French favorite, Madam Non (Mushaben 2017). ${ }^{4}$ She has graced countless magazine covers drawing on Terminator, Muslim, Nazi, Mother Teresa and Mutti images. Although most labels seem to downplay her strength as a female leader, their gendered nature suggests just the opposite. Over time the Chancellor has learned that her best defense against sexist onslaughts is to combat them with humor.

As Germany's first eastern female chancellor, Merkel's status as a double-outsider forced her to make up and play by her own leadership rules, ironically rendering her the embodiment of the feminist mantra, "the personal is the political." Her unusual socialization experiences have had a cumulative impact on her performance, but one can still discern instances in which one factor prevails over others. Whereas Merkel's east-to-west re-acculturation exerts influence over policy substance, her upbringing as a pastor's daughter in a "godless" state drives a strong commitment to human rights and freedom-of-movement norms. Gender influences, combined with her post-GDR antipathy towards confrontational, ideological positions factor into her leadership style (Eagly/Johannesen-Schmidt 2011; Glaesner 2009). The physicist, meanwhile, is clearly at work in matters of program design and evaluation. My study of Merkel's career trajectory since 1990 leads me to stress three factors shaping her reluctance to embrace the feminist label: a desire to position herself between the antithetical nature of eastern and western gender regimes from 1949 to 1989; her time-tested method of "learning by doing"; and her preference for pragmatic problem-solving over ideological party-principles. 


\section{A Tale of Two Feminisms}

The Kohl government deliberately relegated "women's issues" to the back burner throughout the unification negotiations, despite impressive feminist mobilization in the east (Ritter 2007). Rather than import foreign workers, GDR leaders had responded to a dramatic postwar labor shortage by opening educational and occupational doors to its own women. More pro-natalist than egalitarian in nature, SED policies helped to reconcile work-and-family obligations for women after 1971, though they did nothing to redefine the gender division of labor (Kolinsky/Nickel 2003; Voth/Kootz 1990). GDR women had benefited from "emancipatory" policies that FRG feminists lacked, i.e., free contraception, legal abortion, generous leave policies, comprehensive childcare and access to non-traditional professions (Bergahn/Fritzsche 1991). Internally divided, western feminists were too busy critiquing patriarchy, and each other, to pursue pragmatic, single-issue coalitions (Mushaben 1989; Young 1999). Defeated in their efforts to secure legal abortion, and frustrated by cultural misunderstandings, both groups returned to their separate niches within a few years, with feelings of betrayal on both sides (Mushaben 1995; Miethe 2014; Rohnstock 1994; Unabhängiger Frauenverband 1990). Given her GDR socialization and her physics career, one can understand Merkel's hesitation to view women's paid employment and state-supported child-care as radically "feminist" demands. Nor she was looking to exchange one "ism" for another, after "35 years in the waiting room of democracy" (Grunenberg 2000). As the leader of united Germany, Merkel could not identify with one feminist school without alienating the other. Ironically, the EU-mandated reconciliation policies which she introduced after 2005 - deliberately blocked by her SPD predecessor - strongly resembled GDR policies eliminated by unification (Lang 2017).

A political neophyte in 1990, Merkel's first two Cabinet portfolios covered areas conservatives had always loved to hate: women's rights and environmental protection. Socialized in a system in which over $90 \%$ had been working mothers, compared to only 60\% among western Baby Boomers (Mushaben 1995; Winkler 1990, 108113 ), the eastern physicist was pressured from all sides regarding reproductive rights. Few realized at the time that former Chancellor Kohl had already turned primary responsibility for abortion legislation over to the Justice and Health Ministries (Mushaben 1997). Recovering from a broken leg in 1992, which she characterized as "lucky break," Merkel found time to read about, discuss and grasp the conflicting gender expectations invoked by her appointment, even among CDU/CSU women: "Naturally ... it's not easy for many women in my own caucus who are older than I to accept my approach to women's policies ... Many had plowed through and struggled for 10, 15 years, then German unification came and suddenly I'm sitting in the armchair as the Women's Minister" (quoted in: Koelbl 1999, 52). Her W20 comments mirror her earlier reluctance to claim credit for what other women had achieved; they also reflect her desire to avoid ideological stances, based on her GDR upbringing and her physics-driven preference for data-based policies. 


\section{Evidence-based Learning}

A second factor shaping Merkel's reluctance to identify as a feminist owes to her proclivity for "learning by doing," known to natural scientists as the trial-and-error approach. As a non-feminist Women's Minister, she initially "wanted nothing to do with quotas" which she saw as "degrading and defamatory." She changed her mind after observing the barriers women faced in her own party, voting for a CDU "quorum" in 1994. Merkel also initially rejected corporate boardroom quotas demanded by Labor Minister Ursula von der Leyen in 2011. Forced to clean up the Euro-crisis mess created by unsupervised males dominating global finance, she reversed her position in 2014 , accepting mandatory $30 \%$ targets after studies demonstrated that "voluntary" quotas had failed to increase women's presence on supervisory boards among major businesses and DAX firms. Studies cited in EU fact-sheets also showed that women's presence on corporate boards tends to increase company earnings (cf. European Commission 2016), a fact that would not have escaped a data-driven Chancellor.

Although she refused to play the gender card during her first two election campaigns (Mushaben 2018; Merkle 2015; Scholz 2007), the Chancellor now admits to having been disadvantaged as a female politician (Koelbl 1999; Lau 2009). She perceived the self-serving, tough-guy behavior of western politicians in the Cabinet as "unpleasant." When she tried to outlaw sexual harassment at the workplace and to fill half of all civil service positions with women - as foreseen by the unification treaty - CSU Carl-Dieter Spranger told Merkel, "You know, girl, if I didn't find you so nice, I wouldn't vote for any of this rubbish" (quoted in: Lau 2009, 53). Despite her physics background, she noted that "many thought because I was a woman I didn't know what I was talking about (as Environmental Minister) (...) since I lacked a deep male voice and a big physique" (quoted in: Koelbl 1999, 55-56). In one case, she was pushed to tears over her proposed Ozone Law, but she turned it to her advantage: "They weren't used to me having an emotional outbreak since I didn't shout like the men (...) but it helped. I probably wouldn't have gotten a (Cabinet) majority without it" (quoted in: Koelbl 1999, 54-55).

Her gendered learning experiences did not stop there. In 1998, conservative hardliners including Catholic Archbishop Meisner pushed her to marry her partner of seventeen years, Joachim Sauer, prior to becoming CDU General-Secretary. Former pastor Joachim Gauck faced few if any pressures regarding his unsanctified relationship with Daniela Schadt when he became Federal-President. Or consider Merkel's response to Gerhard Schröder, SPD Minister-President of Niedersachsen, who invited her to negotiate over nuclear waste storage, then immediately leaked their discussion. Figuring out the "constants" in male political behavior, she struck back in 1997, finding a way to pass the Nuclear Law without Länder consent. Schröder, she noted, "just can't stand it when a woman, in particular, manages to ruin his game. He's not very good at accepting failure" (quoted in: Koelbl 1999, 58). During the 2005 campaign, he tried to deny her the Chancellorship by using Doris Schröder- 
Köpf to declare that "a childless female leader" would be incapable of producing good family policies. Never mind the fact that the latter's status as Schröder's fourth wife suggested that he knew even less about stable family relations. ${ }^{5}$ Merkel's ability to observe first, follow the rules and strike later also served her well in eliminating core male rivals who comprised the so-called Andes Pact.

A further example of learning-by-doing stems from Merkel's days as an unloved environmental minister. Although she initially backed the nuclear energy industry, the castor transport scandal (1994-1995) taught her not to trust its routine safety pronouncements. Given her working knowledge of the industry's minimal insurance coverage (1\%) in the event of a German melt-down (Hennicke/Welfens 2012), the former physicist was the only leader beyond Japanese prime minister Naoto Kan who could read the atomic tea leaves after Fukushima. Her decision to shut down of all atomic reactors by 2022 was data-driven but also tied to her recognition of the cost of "human error."

\section{Progressive Principles versus Pragmatic Problem-Solving}

Some feminist critics maintain that their first female Chancellor adopted certain gender-friendly policies largely to advance the electoral fortunes of her own party, but that is exactly what politicians are expected to do in democratic societies. They do not explain why she pursued such policies despite formidable resistance within the CDU/CSU caucus. Throughout the lackluster 2017 election campaign, the threetime Chancellor was singularly blamed not only for the rise of the AfD (due to her strong stance on asylum) but also for her "anti-democratic depoliticization" of many contentious issue debates. This raises the counter-question: Why did the SPD-Green government not adopt reforms that its own voters wanted, in order to shore up that coalition's re-election prospects?

While the Greens indirectly welcomed Merkel's take-over of "their" issues (reflected in their willingness to join a Jamaica Coalition), the SPD remains deeply divided over its "stolen" identity after two Grand Coalitions. In fact, Chancellor Schröder personally blocked many of the equality initiatives championed by his female Cabinet members, 1998-2005. In addition to embracing Harz IV reforms which expanded the low-wage, female "precariat," Red-Green legalization of prostitution contributed to documented increases in "wellness-brothels," flat-rate sexploitation and human trafficking (Meyer et al. 2013). That government likewise failed to enact a bona-fide immigration law, much less EU-mandated anti-discrimination and reconciliation policies. Although the Greens count gender equality among their four core pillars, they did not mobilize grassroots support to counter Schröder's (or Schily's) vetoes; it is hard to justify the charge that Merkel stole their issues, given that these allegedly proequality parties had refused to act on their own principles for seven years.

By contrast, Merkel's first Grand Coalition finally adopted the Allgemeine Gleichbehandlungsgesetz in 2006 and created a federal office to monitor discrimination. Her 2007 National Integration Plan, added to further migration and asylum reforms through 
2013 (Mushaben 2017), included significant "implementation monitoring" mechanisms. Although she voted against the Ehe für Alle act in 2017, the Chancellor (having "done the math"), allowed CDU parliamentarians to vote their conscience, securing a clear majority for that bill. She has pushed the Union as a whole to break with the tradition of "Kinder, Küche, Kirche", going so far as to adopt a liberal transsexual-rights law (Davidson-Schmich 2017). She has also accorded "Chefsache" status to programs increasing female and ethnic minority presence in MINT/STEM fields. Though she does not deserve all of the credit, Merkel's leadership style has produced some amazing results, especially in comparison to the Kohl and Schröder legacies.

\section{Revisiting the Metrics of Representation}

Concentrating on women's numerical presence, descriptive representation is usually measured in parliamentary terms; it assumes that sex-based stereotypes and malenormed policies will wither away once they women reach critical-mass, roughly $30 \%$ (Dahlerup 1988). Women had already crossed that threshold before Merkel became Chancellor, but their share rose slightly from $31.8 \%$ (2005), to $33.4 \%$ (2009), then to $37 \%$ (2013). After the 2017 elections, their share of seats fell to $30.9 \%$. The parties that rail the loudest against Merkel's policies evince the smallest female delegations, viz. the AfD (10 of 92 seats), the FDP (19 of 80) and the CSU (8 of 47). AfD and FDP gains, along with SPD losses, explain most of the decline (cf. Deutscher Bundestag 2017). Confined to legislative bodies, descriptive-data tell us little about potentially powerful women behind the scenes, raising the question: Has Merkel's staying-power since 2005 chipped away at gender imbalances within the executive branch (Annesley/Gains 2010)? Collectively derided as Girls' Camp, Merkel's inner circle includes savvy female politicians, powerful media moguls as well as discrete, reform-oriented men. Women comprise nearly 50\% of the Federal Chancellor's Office staff, half of whom were under 40 in 2008. The total number of women present in Merkel's first three Cabinets ranged from six to eight; she promised women $50 \%$ of the portfolios as of 2017. Ursula von der Leyen's appointment as Germany's first female defense minister in late 2013 is particularly noteworthy, as is Merkel's annual Girls' Day meeting with young women at the Chancellery.

Increasing women's numerical strength is ultimately a function of "all things being equal," which they usually aren't, obliging us to consider Merkel polices that level the societal playing field. Substantive representation pertains to women's ability to reshape legislated policies, beyond the presumption that they are "natural" experts in health, education, welfare and family matters. While Merkel avoided gender themes during her first two campaigns, she declared in May 2013 that real equality will only be achieved "when both men and women change their roles and behaviors." 0 Over three terms she has expanded paternal leave and child-care guarantees to such an extent that Germany is experiencing its first Baby Boom in decades; the current supply of midwives and care-places lags well behind the demand (Heine 2017). 
Obviously, improved leave- and care-options do not constitute a primary reason for producing children, but they can affect the timing of such decisions, along with promotion prospects and pensions for women in paid employment. Of the 19 (out of 450 ) aides who gave birth during Schröder's last 35 months in office, few returned to work. There were 49 births during Merkel's first 32 months, most of whom resumed their posts under family leave options enacted in 2007 under a childless CDU chief. They included Hildegard Müller, the first State-Secretary to return to this office since 1949. The pool of eligibles for high administrative office has expanded accordingly. The general share of female employment has risen over $10 \%$ since 2005 , and more women than ever before are living off their own wages across united Germany: from $64 \%$ in 2006, up to $72 \%$ in 2016 (Destatis 2016, 6ff).

While her holistic, data-driven approach may not meet all the formal criteria associated with EU gender mainstreaming, Merkel's contributions to equality at home have certainly outpaced those of the Barroso and Juncker Commissions. Many women beyond Germany's borders have experienced less positive outcomes under austerity policies, however, leading us back to the W20/G20 summit.

\section{Words vs. Deeds: Transformational Representation}

Transformative representation, as I define it, seeks to establish strategic parameters for future changes, as opposed to responding to women's everyday survival needs. Justified or not, the 400 delegates attending the 2017 W20 summit expected a more pro-active response from a female Chancellor than they had from the Turkish and Chinese prime ministers hosting earlier G20 meetings. During the April $25^{\text {th }}$ panel discussion, Ivanka Trump declared that her father had "made everything possible" for her. In a gender-equal society, a woman would not need either her father's help or a $\$ 50$ million trust fund to shape her own life. Nor would a real feminist directly exploit poor female workers in Chinese factories licensed to produce her clothing line (Harwell 2017). Self-proclaimed feminist Christine Lagarde became the first woman to head the IMF, having been appointed in the wake of a major sex scandal involving her predecessor, Dominique Strauss-Kahn. Although Lagarde has reportedly introduced policies to enhance women's status within her own organization, her IMFausterity policies have had a devastating impact on less privileged women's lives across the Euro-zone (cf. Elomäki 2012; Rubery/Karamessini 2013), suggesting her limited "feminist" grasp of descriptive versus substantive representation.

Reluctant to take credit for hard work of earlier movements, the German Chancellor delivered a speech at the gala G20 reception, then accepted the Final Communique of the 2017 W20-Dialog Process which, for the first time, has its own section in the larger G20 Final Communiqué. It recommends three specific programs: the \#eSkills4Girls initiative, the Women Entrepreneurs Financing Initiative (We-Fi), and the formation of a Women's Business Leaders' task force. The Germany 2017 Implementation Plan moreover includes concrete "dashboards," timetables and indicators, based on a wide array 


\section{of UN, OECD, ILO, IMF and World Bank statistical reports (see W20 Box). It further calls for W20 access to "mainstream" G20 negotiation tracks and "Sherpa meetings."}

\section{Women20 Germany 2017 Communiqué (Excerpts) 26th April 2017, Berlin, Germany Putting Gender Equality at the Core of the G20}

We, the representatives of the 2017 Women20 (W20) network, are convinced that the G20's goal of inclusive and sustainable economic growth in an interconnected world will not be achieved without the G20's commitment to women's economic empowerment by means of the following targets: (a) full property rights, legal capacity, right to self-determination for women and girls and their effective protection from violence; (b) full access to quality education for girls and women, with special attention on technical and vocational education, e-skills and lifelong learning opportunities; (c) full access on equal terms to productive and financial resources for women; (d) full access to labour markets and decent working conditions for men and women, implementing the G20 Job Quality Framework; (e) equal pay and pension rights for equal and equivalent work; (f) GDP measurement and fair redistribution of unpaid domestic and care work, including more investment in the provision of infrastructure and public services, and; $(g)$ equitable representation of women in decision-making positions with that of men.

G20 policies tend to be gender-blind, but they are not automatically gender-neutral in their outcome. Accordingly:

1. The W20 calls on the $G 20$ member states to systematically integrate gender analysis and gender budgeting into all its agenda, growth strategy and policy frameworks (...).

2. The W20 urges the $\mathrm{G} 20$ to advance member state policies towards the ' 25 by 25 ' target set by $\mathrm{G} 20$ for reducing the gender labour participation gap, resulting in a 25 per cent improvement by 2025, by putting forward national plans of actions and monitoring its progress with support from the OECD and-the ILO.

3. The W20 recommends that the $G 20$ supports women entrepreneurs and female cooperatives to start up and scale their operations, build capacity, ensure their equal access to finance and markets, and accord them their fair share in global value chains.

4. The W20 calls on the G20 to swiftly bridge the widening digital gender divide and take inspiration from the 'Women's Initiative in Developing STEM Career (WINDS)' by setting up a comprehensive 5-year plan for gender-equal digital transformation, thereby partnering with 'EQUALS', an initiative implemented by the International Telecommunication Union (ITU), the GSM Association (GSMA) and UN Women.

5. The W20 calls on the G20's Presidencies to ensure access to the $G 20$ negotiation tracks and G20 Sherpa meetings.

Source: http://www.w20-germany.org/fileadmin/user_upload/documents/W20_ Communique_Final.pdf 
Granting women the right to vote, then electing more women to formulate and execute the law of the land, are only the first two steps in a long process Max Weber (1919) once defined as "the slow boring of hard boards." The feminist movement itself has undergone a long learning process, moving first from demands for equal treatment, to positive action, to gender mainstreaming, and then to factoring in diversity and intersectionality (Woodward 2012). Orthodox feminist theories are often at odds with political realities, which necessitate broader issue coalitions, partisan compromises and a heavy dose of pragmatism. Merkel's mixed motives for pursuing equality policies (e.g., in response to Germany's demographic deficit) has allowed her to pull together new stakeholder groups, who increasingly recognize the benefits of integrating women and minorities into the work-force. While corporations may initially view gender-sensitive policies in instrumental terms, these reforms develop a life of their own, leading to other transformations across society - as even GDR leaders had to recognize.

I recall many personal discussions with German feminists during the 1970s and 1980s, who regularly insisted on the need for a Gesamtkonzept; the problem then arose as to which school of feminism would be able to impose its comprehensive approach on all of the others. This either/or thinking probably had its roots in the male-normed polarization of the late 1960s. The fall of the Wall re-incited this type of debate between western and eastern feminists, while (mostly western) men immediately set out to claim the best jobs, the biggest Treuhand subsidies and the tops jobs in eastern Länder governments (exception: Manfred Stolpe in Brandenburg). GDR-women were hit with mass unemployment, the loss of legal abortion and the elimination of full-time child-care facilities, while more privileged women argued over whose feminism was best.

Having devoted my entire career to pursuing various forms of gender equality, I have come to the following conclusion: There is a proper place for feminist theorizing, conceptual reflection and strategic mobilization, but sometimes single-issue coalitions offer the shortest path to legislative success. The less time we spend worrying about labels, or about who really "qualifies" as a feminist, the more time we have to engage in critical policy analysis, to be shared with women who attain high office, so that they can induce data-driven structural change. My investigation of Merkel's policy performance since 2005 has persuaded me that a woman leader need not openly and regularly declare herself a feminist in order to make a difference. In this case, I concur with another surprising pragmatist from the east, Deng Xiao-ping, who noted in 1979, "it does not matter if the cat is black or white, as long as it catches mice."

\section{Notes}

1 All but one of the books written about Angela Merkel auf deutsch to date have been compiled by journalists. The better ones include Heckel (2009), Lau (2009), Kornelius (2013), MüllerVogg (2005) and Roll (2005).

2 For details, see the official German website, http://www.w20-germany.org and http://g20.org. tr/engagement-groups/women-20-w20/ (30.8.2018) 
3 See https://www.youtube.com/watch?v=oQ-sV97bGIE (30.8.2018)

4 This is only a partial list, granting Merkel the dubious distinction of having had more derogatory, gender-oriented nicknames applied in a shorter period than is true of any of her successors, based on my own search.

5 For the record: They divorced after 2016 when Doris learned about his affair with a younger Korean business-woman through the media.

6 She made this statement during an hour-long interview sponsored by a women's magazine; see Brigitte Talk, https://www.youtube.com/watch?v=9v-1W58s4e8, posted on May 18, 2013.

\section{References}

Abels, Gabriele, 2011: 90 Jahre Frauenwahlrecht: Zum Wandel von Geschlechterverhältnissen in der deutschen Politik. In: Abels, Gabriele (Ed.), 2011: Deutschland im Jubiläumsjahr 2009: Blick zurück nach vorn. Baden-Baden, 197-219.

Annesley, Claire/Gains, Francesca, 2010: The Core Executive: Gender, Power, and Change. In: Political Studies. 58, 909-929.

Beckett, Clare, 2006: Thatcher (British Prime Ministers of the 20th Century). London.

Berghahn, Sabine/Fritzsche, Andrea, 1991: Frauenrecht in Ost und West Deutschland. Berlin.

Carless, Sally A., 1998: Gender Differences in Transformational Leadership: An Examination of Superior, Leader and Subordinate Perspectives. In: Sex Roles. 39 (11/12), 887-902.

Clemens, Clay, 2006: From the Outside In: Angela Merkel as Opposition Leader, 2000-2005. In: German Politics \& Society. 24 (3), 1-19.

Dahlerup, Drude, 1988: From a Small to a Large Minority: Women in Scandinavian Politics. In: Scandinavian Political Studies. 11 (4), 275-298.

Davidson-Schmich, Louise, 2016: Gender Quotas and Democratic Participation: Recruiting Candidates for Elective Offices in Germany. Ann Arbor MI.

Davidson-Schmich, Louise, 2017: LGBT Politics in Germany: Unification as a Catalyst for Change In: German Politics. 26 (4), 534-555.

Destatis, 2016: Arbeitsmarkt auf einen Blick: Deutschland und Europa. Wiesbaden.

Deutscher Bundestag, 2017: Frauen und Männer. Internet: https://www.bundestag.de/abgeordnete/biografien/mdb_zahlen_19/frauen_maenner/529508 (20.7.2018).

Eagly, Alice H./Johannesen-Schmidt, Mary C., 2001: The Leadership Styles of Women and Men. In: Journal of Social Issues. 57 (4), 781-797.

Elomäki, Anna, 2012: The Price of Austerity - The Impact on Women's Rights and Gender Equality in Europe. Brussels.

European Commission, 2016: EU Fact Sheet, Gender Balance on Corporate Boards: Europe is Cracking the Glass Ceiling. Brussels.

Geissel, Brigitte, 2000: Innovative Potenziale von Politikerinnen. In: Aus Politik und Zeitgeschichte. (B31-32), 24-29.

Glaesner, Katje, 2009: Angela Merkel - mit 'Soft Skills' zum Erfolg? In: Aus Politik und Zeitgeschichte. (50), 28-34.

Grunenberg, Nina, 2000: "Und was nun, Männer? In: Die Zeit, 9.9.2000.

Harwell, Drew, 2017: Workers Endured Long Hours, Low Pay at Chinese Factory Used by Ivanka Trump'sClothing-Maker.In:WashingtonPost, 25.4.2017.Internet:https://www.washingtonpost.com/ gdpr-consent/?destination $=\% 2$ fbusiness $\% 2$ feconomy $\% 2$ fworkers-endured-long-hours-low-payat-chinese-factory-used-by-ivanka-trumps-clothing-maker\%2f2017\%2f04\%2f25\%2fb6fe66082924-11e7-b605-33413c691853_story.html\%3f\&utm_term=.236e22a1e5a1. 
Heckel, Margaret, 2009: So regiert die Kanzlerin - Eine Reportage. München.

Heine, Hannes, 2017: Geburten in Berlin - Runder Tisch zum Hebammen-Engpass. In: Der Tagesspiegel, 16.9.2017.

Hennicke, Peter/Welfens, Paul, 2012: Energiewende nach Fukushima: Deutscher Sonderweg oder weltweites Vorbild? München.

Koelbl, Herlinde, 1999: Spuren der Macht. Die Verwandlung des Menschen durch das Amt. Munich.

Kolinsky, Eva, 1991: Political Participation and Parliamentary Careers: Women's Quotas in West Germany. In: West European Politics. 14 (1), 56-72.

Kolinsky, Eva/Nickel, Hildegard Maria, 2003: Reinventing Gender: Women in Eastern Germany since Unification. London.

Kornelius, Stephan, 2013: Angela Merkel. Die Kanzlerin und ihre Welt. Hamburg.

Lang, Sabine, 2017: Gender Equality in Post-Unification Germany: Between GDR Legacies and EU-Level Pressures. In: German Politics. 26 (4), 556-573.

Lau, Mariam, 2009: Die Letzte Volkspartei. Angela Merkel und die Modernisierung der CDU. Munich.

Lombardo, Emanuela/Agustin, Lise Rolandsen, 2011: Framing Gender Intersections in the European Union: What Implications for the Quality of Intersectionality in Policies. Social Politics. 19 (4), 1-31.

Merkle, Susanne, 2015: Personalisierung und genderspezifische Berichterstattung im Bundestagswahlkampf 2013 - "Ausnahmefall" Angela Merkel oder "typische Frau"? In: Holtz-Bacha, Christine (Ed.): Die Massenmedien im Wahlkampf. Die Bundestagswahl 2013. Wiesbaden, 217247.

Meyer, Cordula/Neumann, Conny/Schmid, Fidelius/Truckendanner, Petra/Winter, Stefan, 2013 : Unprotected: How Legalizing Prostitution Failed (Part 1-5). Spiegel Online, 30.5.2013. Internet: http://www.spiegel.de/international/germany/human-trafficking-persists-despite-legality-ofprostitution-in-germany-a-902533.html

Miethe, Ingrid, 2014: Women's Movements in East Germany - Are We in Europe yet? In: Jarausch, Konrad H. (Ed.): United Germany. Debating Processes and Prospects. New York, Oxford, 154-170.

Müller-Vogg, Hugo, 2005: Angela Merkel: Mein Weg. Hamburg.

Mushaben, Joyce Marie, 2018: Kan-di(e)-dat? Unpacking Gender Images across Angela Merkel's Four Campaigns for the Chancellorship, 2005-2017. In: German Politics \& Society. 36 (1), 31 -51.

Mushaben, Joyce Marie, 2017: Becoming Madam Chancellor: Angela Merkel and the Berlin Republic. Cambridge, UK.

Mushaben, Joyce Marie, 1997: Concession or Compromise? The Politics of Abortion in United Germany. In: German Politics. 6 (3), 69-87.

Mushaben, Joyce Marie, 1995: Second-Class Citizenship and its Discontents: Women in United Germany. In: Merkl, Peter (Ed.): The Federal Republic of Germany at 45. New York, 80-98.

Mushaben, Joyce Marie, 1989: Feminism in Four Acts: The Changing Political Identity of Women in the German Federal Republic. In: Merkl, Peter (Ed.): The FRG at 40. New York, 76-109.

Ritter, Gerhard A., 2007: Der Preis der deutschen Einheit. Die Wiedervereinigung und die Krise des Sozialstaates. München.

Rohnstock, Katrin Ritter (Ed.), 1994. Stiefschwestern: Was Ost-Frauen und West-Frauen voneinander denken. Frankfurt/M.

Roll, Evelyn, 2005: Die Erste. Angela Merkel's Weg zur Macht. Reinbek.

Rubery, Jill/Karamessini, Maria (Eds.), 2013: Women and Austerity: The Economic Crisis and the Future for Gender Equality. Abingdon UK. 
Scholz, Sylka (Ed.), 2007: “Kann die das?” Angela Merkels Kampf um die Macht. Berlin.

Schramm, Julie, 2016: Fifty Shades of Merkel. Hamburg.

Spiegel Online, 2008: Plunging Neckline - Merkel 'Surprised' by Attention to Low-Cut Dress. 15.4.2008. Internet: http://www.spiegel.de/international/germany/plunging-neckline-merkelsurprised-by-attention-to-low-cut-dress-a-547512.html

Unabhängiger Frauenverband/Autonome Frauenredaktion im Argument (Eds.), 1990: Ohne Frauen ist kein Staat zu machen. Hamburg.

von Wahl, Angelika, 2011: A 'Women's Revolution from Above'? Female Leadership, Intersectionality, and Public Policy under the Merkel Government. In: German Politics. 20 (3), 392-409.

Voth, Helga/Kootz, Johanna (Eds.), 1990: Gleichstellungspolitik in der DDR und der BRD. Humboldt University Berlin.

Weber, Max, 1919: Politik als Beruf. München, Leipzig.

Wiliarty, Sarah Elise, 2010: The CDU and the Politics of Gender in Germany. Bringing Women to the Party. Cambridge UK.

Winkler, Gunnar (Ed.), 1990: Frauenreport '90. Berlin, 108-113.

Woodward, Alison E., 2012: From Equal Treatment to Gender Mainstreaming and Diversity Management. In: Abels, Gabriele/Mushaben, Joyce Marie (Eds.): Gendering the European Union. Basingstoke UK, 85-103.

Yoder, Jennifer, 2011: An Intersectional Approach to Angela Merkel's Foreign Policy. In: German Politics. 20 (3), 360-375.

Young, Brigitte, 1999: Triumph of the Fatherland. German Unification and the Marginalization of Women. Ann Arbor MI.

\title{
Ausschluss trotz Einschluss. Ungleiche Handlungsressourcen von Bürgermeisterinnen und Bürgermeistern
}

\author{
UTA KLETZING
}

Frauen in der Politik sind nicht mehr die Ausnahme, aber noch längst nicht die Regel. In keinem Parlament Deutschlands seit 1919 sind Frauen gleichberechtigt vertreten gewesen. ${ }^{1}$ Auf der kommunalen Ebene sieht die Frauenrepräsentanz mit durchschnittlich etwa einem Viertel Mandatsträgerinnen sowie mit rund einem Zehntel (Ober-)Bürgermeisterinnen und Landrätinnen am rückständigsten aus. In den Landtagen sind durchschnittlich etwa ein Drittel der Mandate in Frauenhand, allerdings mit einer hohen Spannbreite zwischen etwa 41\% und etwa 25\%. Ministerpräsidentinnen gibt es aktuell zwei, und Deutschland hatte bislang insgesamt sechs. Der höchste Frauenanteil, den der Deutsche Bundestag je vorweisen konnte, lag bei $37 \%$ - und zwar in der letzten Legislaturperiode. Der Rückgang auf 30,9\% Frauen 
im aktuellen 19. Bundestag setzte den Trend sinkender Frauenanteile fort, der auch bei den letzten Landtagswahlen zu beobachten war.

Aus ihrem Status als zahlenmäßige Minderheit und als nicht-,männliche“ Wesen ${ }^{2}$ entsteht gegenwärtig eine paradoxe Situation für Frauen in der Politik: Wie auch in anderen Führungspositionen kommen sie zunehmend vor und sind damit qua formaler Position irgendwie „drin“. Aber auch nach 100 Jahren Frauenwahlrecht dominieren Männer und ,Männlichkeit“ den politischen Raum. Politikerinnen sind also unverändert auch irgendwie „,draußen“. Die diesem Beitrag zugrunde liegende empirisch-analytische Forschung (Kletzing 2017a) geht diesem Ausschluss trotz Einschluss am Beispiel von hauptamtlichen Bürgermeisterinnen ${ }^{3}$ nach.

Mit der Untersuchung der Handlungsressourcen von Kandidat_innen in der Wahlsituation und von Bürgermeister_innen in der Regierungssituation verbindet sich ein Perspektivwechsel gegenüber der bisherigen politikwissenschaftlichen GenderForschung zur Unterrepräsentanz von Frauen in der Politik. Bisherige Frauenrepräsentanz-Forschung hat mögliche Mechanismen des Ein- und Ausschlusses herausgearbeitet, die den grundsätzlichen Zugang zu politischen Entscheidungs- und Führungspositionen geschlechtlich strukturieren. Möglichen Ausschlüssen auch nach Erreichen der Entscheidungs- und Führungspositionen als Nominierte bzw. Gewählte, also den möglicherweise ungleichen Bedingungen (Ausschluss) trotz gleicher Position (Einschluss) galt bislang kaum wissenschaftliche Beachtung.

Für diese Ausschlüsse der qua formaler Position Gleichen bzw. Eingeschlossenen interessiert sich die vorliegende Forschung mit der Frage nach den Handlungsressourcen und damit nach dem Ausgebremst-Werden bzw. Angeschoben-Werden von Kandidat_innen bzw. Bürgermeister_innen. Machen Verteilung und Verteilungsmechanismen von Handlungsressourcen die Kandidatinnen bzw. Bürgermeisterinnen zu ausgeschlossenen Eingeschlossenen?

Nach Überblicken über die theoretisch-konzeptionelle Ausgangslage sowie über die Daten und Vorgehensweise der Untersuchung beantworten die Ergebnisse zwei Fragen: Worin genau bestehen die Ausschlüsse für Kandidatinnen bzw. Bürgermeisterinnen? Und was lässt sich daraus für weitere Forschung und politische Praxis ableiten? Der Beitrag schließt mit einem Fazit, das für einen Kulturwandel in der Politik plädiert sowie für ein Paritätsgesetz, um diesen anzustoßen.

\section{Theoretischer Rahmen, Forschungsannahmen, Forschungsstand}

Sowohl bei der theoretischen Fundierung als auch bei dem einbezogenen Forschungsstand wurden Brücken zwischen politikwissenschaftlicher Gender-Forschung und politik- bzw. kommunalwissenschaftlicher Führungsforschung geschlagen. ${ }^{4}$ Für die theoretische Rahmung wurde die „Forschungsheuristik“ (Mayntz/Scharpf 1995, 39) des Akteurzentrierten Institutionalismus (AzI) mit der theoretischen Konzeptualisierung von Geschlechtergerechtigkeit (Pimminger 2012) ${ }^{5}$ kombiniert. Der AzI bietet einen Rahmen, um Gender im theoretischen Forschungsansatz als eine 
Institution der Makro- und Meso-Ebene (neben anderen) und die Genusgruppe als ein Akteursmerkmal der Mikro-Ebene (neben anderen) zu definieren. Die drei Gender-Dimensionen von Pimminger (2012) - Geschlechternorm, Geschlechterordnung, Geschlechterstruktur - legen zum einen nahe, dass Gender und Genusgruppe erklärungsrelevante Kontextfaktoren für Handlungsressourcen und Handeln sind. Zum anderen umreißen die für jede Gender-Dimension definierten Mechanismen, die systematisch Geschlechterungerechtigkeit erzeugen (wie z.B. Heteronormativität, Androzentrismus, geschlechtliche Arbeitsteilung), die Wirkweisen, wie sich Gender und Genusgruppe auf Handlungsressourcen und Handeln auswirken können.

Folglich begründete der theoretische Forschungsansatz die Forschungsannahme des Ausschlusses: Geschlechternorm, Geschlechterordnung (u.a. double bind ${ }^{6}$ ) und Geschlechterstruktur (u.a. Werdegänge/Lebenszusammenhänge, Vereinbarkeitssituation) weisen den Kandidat_innen und den Bürgermeister_innen unterschiedliche Ausgangslagen zu.

Aus dem AzI leitet sich auch das Konzept der Handlungsressourcen ab. Handlungsressourcen sind nach Scharpf $(2000,86)$ Ausgangslagen, ,die es einem Akteur ermöglichen, ein Ergebnis in bestimmter Hinsicht und zu einem gewissen Grad zu beeinflussen“. Für die Handlungssituationen von Bürgermeister_innen sind diejenigen Ausgangslagen relevant, die die Chancen der Kandidat_innen auf Wahlerfolg bzw. die Chancen der Bürgermeister_innen auf Amtserfolg maßgeblich mitbestimmen.

Die Untersuchung der Handlungsressourcen ermöglicht Antworten auf die Frage, inwiefern Gender Handlungssituationen vorstrukturiert und das Handeln von Bürgermeister_innen von vornherein in geschlechtlich strukturierte Bahnen lenkt. Damit soll exemplarisch „,entdeckt bzw. aufgedeckt“" werden, „wie Geschlechtsunterscheidungen hervorgebracht bzw. gemacht werden“" (Krell 2004b, 386) und wie „,institutionalisierte Reproduktionsweisen von Zweigeschlechtlichkeit“ (Wetterer 2004, 128) verfasst sind und zustande kommen.

Der Forschungsstand zu hauptamtlichen Bürgermeister_innen (u.a. Lukoschat/ Belschner 2014; Bertelsmann Stiftung/Deutscher Städtetag/Deutscher Städte- und Gemeindebund 2008; Bogumil/Heinelt 2005; Scholz 2004) und zu anderen Berufspolitikerinnen (u.a. Schaeffer-Hegel u.a. 1998; Meyer 1997) gestaltet sich insgesamt eher überschaubar. Auch lassen politikwissenschaftliche Gender-Forschung auf der einen Seite und politik- und kommunalwissenschaftliche Führungsforschung auf der anderen Seite als bisherige Parallelwelten stets eine Perspektive auf ihren Forschungsgegenstand vermissen: entweder die Perspektive auf Bürgermeister_innen als kommunale Spitzenpolitiker_innen, die auch in Eigenlogiken des (kommunal-) politischen Feldes eingebunden sind, oder die Perspektive auf Bürgermeister_innen, die auch einer Genusgruppe angehören und deren Handlungssituationen damit auch durch Gender geprägt sind. Damit entgehen beiden Forschungssträngen wertvolle Antworten auf die je eigenen Forschungsfragen.

Der Forschungsstand, der den Ausgangspunkt der vorliegenden Forschung bildete, ${ }^{7}$ lässt sich wie folgt zusammenfassen: Die politikwissenschaftliche Gender-For- 
schung hat vornehmlich die Wahlsituation ins Visier genommen, um die Unterrepräsentanz von Politiker_innen zu erklären. Die Ursachen werden in erster Linie in den Werdegängen und Lebenszusammenhängen von Politiker_innen und in der Rolle von Parteien als Gatekeeper verortet (u.a. Kletzing/Lukoschat 2010; Holtkamp/Schnittke 2010). Auch hat die politikwissenschaftliche Gender-Forschung die grundsätzlich ,männliche“ Kodierung der Wahlsituation und der Regierungssituation nachgewiesen (u.a. Schaeffer-Hegel et al. 1998). Angesichts des übergreifenden androzentrischen Wirkmechanismus der ,Setzung männlicher Standards, die Frauen als defizitär erscheinen lassen“ (Pimminger 2012,134) stellt sich für das politische Feld die Frage, worin sich ,männliche“ Standards in der Wahlsituation von Kandidat_innen und in der Regierungssituation von Bürgermeister_innen zeigen und wie sie wirken. Um diese Frage zu beantworten, bedarf es - anders als in bisheriger politikwissenschaftlicher Gender-Forschung - des Einbezugs von Männern als Untersuchungsgruppe und von Konzepten kommunalwissenschaftlicher Führungsforschung.

Auch die kommunalwissenschaftliche Führungsforschung hebt die Rolle der Gatekeeper von Parteien in der Wahlsituation von Bürgermeister_innen hervor und zeichnet die gegenwärtige soziale Praxis der Eignung(sbeurteilung) von Kandidat_innen entlang von Auswahlverfahren und -kriterien nach (u.a. Gehne 2008). Insgesamt bleibt der Stand des systematischen Forschungswissens über die zentralen „Standard Operating Procedures“ (ebd., 35) in der Wahlsituation von Bürgermeister_innen, also von potenziell ausschlussrelevanten Spielregeln, jedoch auch seitens der kommunalwissenschaftlichen Führungsforschung unbefriedigend. Vergleichsweise dezidierter als die politikwissenschaftliche Gender-Forschung hat sich die kommunalwissenschaftliche Führungsforschung mit der Regierungssituation von Bürgermeister_innen befasst (u.a. Holtkamp 2008; Bogumil/Heinelt 2005). Trotz weitgehender Gender-Blindheit der Forschungen werden mit den Kontextfaktoren des kommunalpolitischen Feldes zentrale Drittvariablen definiert und Strukturierungen eröffnet, auf die Gender-Analysen aufsetzen können. Auch ermöglichen Konzeptualisierungen von Wahlerfolg und Amtserfolg, die relevanten Handlungsressourcen von Bürgermeister_innen in der Wahlsituation und in der Regierungssituation abzustecken (u.a. Bogumil/Holtkamp 2005; Grasselt/Korte 2008).

Anders als die theoriebasierte Forschungsannahme des Ausschlusses veranlasste der Forschungsstand eher zur Einschlussthese: Als von ihren Parteien nominierte Kandidat_innen und von den Bürger_innen gewählte Bürgermeister_innen erfahren sie keine geschlechterbedingten manifesten Platzanweisungen in Form von unterschiedlichen Handlungsressourcen. ${ }^{8}$

\section{Daten und Vorgehensweise}

Ziel der Analyse ist es, die Chancen der Kandidat_innen auf Wahlerfolg bzw. die Chancen der Bürgermeister_innen auf Amtserfolg zu untersuchen. Dafür wurden die 
quantitative Verteilung von fünf relevanten Handlungsressourcen sowie die Mechanismen, die die jeweilige Verteilung hervorbringen, für insgesamt 22 hauptamtliche Bürgermeister_innen (jeweils elf Bürgermeisterinnen und Bürgermeister) sowohl in der Wahl- als auch in der Regierungssituation ermittelt. Sie führen Mittelstädte mit 20.000 bis 100.000 Einwohner_innen in Nordrhein-Westfalen (NRW) und gehören der SPD an. ${ }^{9}$

In NRW gab es zum Zeitpunkt der Interviewvorbereitung (Januar 2012) in besagter Gemeindegrößenklasse 16 hauptamtliche Bürgermeisterinnen, von denen die parteibezogen größte homogene Gruppe von elf Bürgermeisterinnen der SPD angehörte. Die Vergleichsgruppe der elf Bürgermeister wurde so ausgewählt (aus insgesamt 51), dass sie den jeweiligen Gemeindegrößen der Bürgermeisterinnen am nächsten kam.

Mittels mündlicher leitfadengestützter Einzelinterviews und eines Fragebogens wurden die subjektiven Einschätzungen der 22 Bürgermeister_innen erfragt und um objektive Daten und Fakten aus Internet-Recherchen ergänzt. Tabelle 1 zeigt im Überblick die Erhebungs- und Auswertungskategorien, wie sie in Interviewleitfaden, Fragebogen, Recherchen und auch in den Kategorisierungs- und Kodierungsleitfaden für die Datenauswertung, die im Wesentlichen mit der qualitativen Inhaltsanalyse von Mayring (2003) erfolgte, eingeflossen sind. ${ }^{10}$

Tabelle 1: Erhebungs- und Auswertungskategorien

\begin{tabular}{|c|c|}
\hline Werdegänge/Lebenszusammenhänge & $\begin{array}{l}\text { - Lebensalter, Dienstalter } \\
\text { - } \text { politisch-beruflicher Werdegang } \\
\text { - } \text { lokale Bindung } \\
\text { - Familienverhältnisse }\end{array}$ \\
\hline Wahlsituation & $\begin{array}{l}\text { - } \text { politischer Einstieg } \\
\text { - Kandidatur } \\
\text { - Amtsvorgänger_in, primäre_rWWahlgegner_in } \\
\text { - Zusammensetzung Rat und Parteizugehörigkeit } \\
\text { Bürgermeister_innen seit } 1994\end{array}$ \\
\hline Regierungssituation & $\begin{array}{l}\text { - Zusammensetzung Rat in der Amtsstadt seit } \\
\text { - Amtsübernahme } \\
\text { - Amtseinstieg und Amtsverlauf } \\
\text { - Führung der Arenen und arenenübergreifende } \\
\text { - Führung } \\
\text { (politischer) Erfolg }\end{array}$ \\
\hline
\end{tabular}


Für jeden der 22 Fälle lagen ein ausgefüllter Fragebogen, die Interviewtranskription und systematisch von der Autorin (und Interviewerin) dokumentierte erste Eindrücke rund um die Interviewsituation für die Datenauswertung vor. Jedem_r Bürgermeister_in wurde auf Basis dieser Daten eine Ausprägung der jeweiligen Handlungsressource - uneingeschränkte, eingeschränkte oder keine Handlungsressource - zugewiesen.

\section{Ergebnisse}

Es lassen sich zwei zentrale Ergebnisstränge zusammenfassen: Erstens, die Verteilung der Handlungsressourcen ergibt für die Kandidatinnen bzw. Bürgermeisterinnen nachteilige Ausgangslagen. Zweitens, die nachteilige Verteilung der Handlungsressourcen kann jedoch dem Erfolg der Kandidatinnen bzw. Bürgermeisterinnen nichts anhaben. ${ }^{11}$

\section{Handlungsressourcen der Wahlsituation}

Tabelle 2 stellt die Handlungsressourcen, die für Kandidat innen in der Wahlsituation als relevant definiert wurden, sowie deren Indikatoren überblicksartig dar.

Tabelle 2: Handlungsressourcen der Wahlsituation und ihre Indikatoren im Überblick

\begin{tabular}{|l|l|}
\hline Handlungsressourcen & (Unter-JIndikatoren \\
\hline Eignung(sbeurteilung) & $\begin{array}{l}\text { - Übereinstimmung mit heuristischen } \\
\text { Eignungskriterien }\end{array}$ \\
\hline situative Wahlchancen & $\begin{array}{l}\text { - begünstigende vs. erschwerende parteipolitische } \\
\text { "Großwetterlage“ (Helms 2008: 19)* in der Amtsstadt } \\
\text { - schwache_r vs. starke_r primäre_r Wahlgegner_in }\end{array}$ \\
\hline Rückhalt der Ortspartei & $\begin{array}{l}\text { - Beurteilung der Eignung seitens Ortspartei } \\
\text { - Beurteilung der situativen Wahlchancen seitens Orts- } \\
\text { partei }\end{array}$ \\
& $\begin{array}{l}\text { - Umstände der Bewerbung um die Kandidatur } \\
\text { Grad der aktiven Partei- und Politiksozialisation }\end{array}$ \\
\hline
\end{tabular}

* Der Begriff geht auf die .politische und ökonomische .Großwetterlage “” von Helms $(2008,19)$ zurück, die er als einen unter mehreren Einflussfaktoren für die Regierungsführung definiert.

\section{Eignung(sbeurteilung)}

Die Handlungsressource „Eignung(sbeurteilung)“12 basiert auf dem (objektivierten) Eignungsmaß, welches sich aus dem Grad der Übereinstimmung der Werdegänge und Lebenszusammenhänge der Kandidat_innen mit den heuristischen Eignungs- 
kriterien des KandidatEN-Profils ${ }^{13}$ ergibt. Das individuelle Merkmalsprofil der Kandidat_innen wurde zunächst den ausführlich erhobenen Werdegängen und Lebenszusammenhängen der Befragten entnommen. ${ }^{14}$ Dann wurde es mit dem KandidatEN-Profil abgeglichen, welches sich aus den Befunden bisheriger Bürgermeister_innen-Forschung (u.a. Gehne 2002) ableiten ließ. Folgende Merkmale stellen sich in Form des KandidatEN-Profils als idealtypisch für die positive Eignung(sbeurteilung) heraus:

- Genusgruppe: Mann

- Lebensalter: über 45 Jahre

- politisch-beruflicher Werdegang: hoher Ausbildungs- und Berufsstatus; kommunalpolitische Erfahrung oder kommunale Verwaltungserfahrung

- lokale Bindung: stark

- Familienverhältnisse: ,normal“ (eheliche Kernfamilie) und Verfügbarkeit absichernd (keine Fürsorgepflichten)

Der Abgleich ergab für jede_n Kandidatin_en eine einschlägige oder nicht einschlägige Eignung(sbeurteilung).

Der Forschungsstand und auch die Aussagen der Bürgermeister_innen legen nahe, dass insbesondere die Eignung(sbeurteilung) geschlechtlich strukturierte Ausschlüsse erzeugt und gleichzeitig immens relevant für den Wahlerfolg ist. Für die Kandidat_innen ist die eigene Beurteilung ihrer Eignung Quelle vom Standing in der Wahlsituation. Sie bedingt, sehr sicher vs. sehr verunsicherbar in eigener Sache aufzutreten - sowohl gegenüber der eigenen Ortspartei als auch gegenüber den Wähler_innen. Des Weiteren fließt die Eignungsbeurteilung der Ortspartei in den Rückhalt für die_den Kandidatin_en und in die Überzeugungskraft des Wahlkampfes ein. Kurzum: Wenn Kandidat_innen von sich selbst und ihre Ortsparteien von ihnen als „die Richtigen“ überzeugt sind, setzt dies andere (individuelle und kollektive) Energien für die Wahlsituation frei als wenn nicht - das macht die Eignung(sbeurteilung) zur Handlungsressource.

Angesichts der androzentrischen Eignungskriterien des KandidatEN-Profils überrascht es wenig, dass weniger Kandidatinnen (2) als Kandidaten (7) eine einschlägige Eignung und mehr Kandidatinnen (9) als Kandidaten (4) eine nicht einschlägige Eignung bescheinigt bekommen (Tab. 3).

\section{Situative Wahlchancen}

Dass die meisten Kandidatinnen ihrer Erstwahl wenig optimistisch entgegenblicken, wird auch durch die Verteilung der zweiten Handlungsressource erzeugt: die situativen Wahlchancen. Damit ist die Wahrscheinlichkeit des Wahlerfolgs gemeint, die sich unabhängig von der_dem Kandidat_in aus bestimmten situativen Gegebenheiten in der Amtsstadt ableiten lässt. Als ein zentraler objektiver Indikator der 
situativen Wahlchancen gilt (u.a. Gehne 2008) die den Wahlerfolg begünstigende vs. erschwerende parteipolitische Großwetterlage in der Amtsstadt, die sich aus folgenden Faktoren zusammensetzt: erstens, welche Partei die Ratsmehrheit hat; zweitens, welches Parteibuch die_der amtierende Bürgermeister_in hat; drittens, wie (in-)stabil sich Ratsmehrheit und Parteibuch der Bürgermeister_innen über mehrere Legislaturperioden hinweg darstellen.

Der zweite Indikator für eher schlechte bzw. eher gute Wahlchancen besteht in der Schwäche vs. Stärke der primären Wahlgegner_innen: Ist es z.B. ein_e Amtsinhaber_in mit/ohne Amtsbonus? Ist der amtierende Bürgermeister regulär-langfristig oder unerwartet-kurzfristig ausgeschieden? Halten die Kandidat_innen ihre Konkurrent_innen für mehr oder weniger geeignet als sich selbst?

Alle diese (Unter-)Indikatoren zusammen ergeben die Ausprägung der je individuellen situativen Wahlchancen der Kandidat_innen. Das Mittelfeld der gemischten Wahlchancen betrifft Kandidatinnen und Kandidaten gleichermaßen (6:6). Jedoch kandidieren mehr Kandidatinnen (4) als Kandidaten (2) mit sehr schlechten und weniger Kandidatinnen (1) als Kandidaten (3) mit sehr guten Wahlchancen (siehe Tabelle 3). Auch die situativen Gegebenheiten in der Amtsstadt bescheren den Kandidatinnen also eine im Vergleich zu den Kandidaten nachteilige Ausgangslage für ihre Erstwahl.

\section{Rückhalt der Ortspartei}

Eine dritte Handlungsressource der Wahlsituation ist der Rückhalt der Ortspartei, also wie sehr die Ortspartei als Kapital (z.B. für den Wahlkampf) der Kandidat_innen mobilisierbar ist. Die Datenlage ergab, dass der formale Rückhalt der innerparteilichen Nominierung insbesondere für die Kandidatinnen nicht selbstverständlich mit dem Rückhalt der Ortsparteien in Form von moralischer und praktischer Unterstützung einhergeht. Lediglich vier der elf Kandidatinnen wird der uneingeschränkte Rückhalt ihrer Ortspartei zuteil. Kandidatinnen müssen also nicht nur die Wähler_ innen gewinnen, sondern - häufiger als die Kandidaten - darüber hinaus auch ihre Ortsparteien dafür gewinnen, dies gemeinsam mit ihnen zu tun.

Tab. 3 zeigt zusammenfassend, dass jeweils mehr Kandidatinnen als Kandidaten in der Wahlsituation die eingeschränkte oder nicht vorhandene Ausprägung der Handlungsressource zuteil wird, dagegen mehr Kandidaten als Kandidatinnen die uneingeschränkte Ausprägung. 
Tabelle 3: Verteilung der Handlungsressourcen der Wahlsituation auf die Kandidatinnen und Kandidaten

\begin{tabular}{|c|c|c|c|c|c|c|}
\hline \multirow[t]{2}{*}{$\begin{array}{l}\text { Handlungsres- } \\
\text { sourcen (HR) }\end{array}$} & \multicolumn{6}{|c|}{$\begin{array}{l}\text { Verteilung der Ausprägungen der Handlungsressourcen auf die Kandida- } \\
\text { tinnen (IN, } N=11 \text { ) und Kandidaten (ER, } N=11 \text { ) }\end{array}$} \\
\hline & IN & ER & IN & ER & IN & ER \\
\hline & \multicolumn{2}{|c|}{ uneingeschränkte HR } & \multicolumn{2}{|c|}{ eingeschränkte HR } & & \\
\hline \multirow{2}{*}{$\begin{array}{l}\text { Eignung(sbe- } \\
\text { urteilung) }\end{array}$} & \multicolumn{2}{|c|}{ einschlägig } & \multicolumn{2}{|c|}{ nicht einschlägig } & & \\
\hline & 2 & 7 & 9 & 4 & & \\
\hline \multirow{2}{*}{$\begin{array}{l}\text { situative } \\
\text { Wahlchancen }\end{array}$} & \multicolumn{2}{|c|}{ sehr gut } & \multicolumn{2}{|c|}{ gemischt } & \multicolumn{2}{|c|}{ seht schlecht } \\
\hline & 1 & 3 & 6 & 6 & 4 & 2 \\
\hline \multirow{2}{*}{$\begin{array}{l}\text { Rückhalt der } \\
\text { Ortspartei }\end{array}$} & \multicolumn{2}{|c|}{ uneingeschränkt } & \multicolumn{2}{|c|}{ eingeschränkt } & & \\
\hline & 4 & 7 & 7 & 4 & & \\
\hline
\end{tabular}

Handlungsressourcen der Regierungssituation

Folgende Handlungsressourcen wurden als für Bürgermeister_innen in der Regierungssituation relevant definiert und mit folgenden Indikatoren erfasst:

Tabelle 4: Handlungsressourcen der Regierungssituation und ihre Indikatoren im Überblick

\begin{tabular}{|l|l|}
\hline Handlungsressourcen & (Unter-JIndikatoren \\
\hline parteipolitische Ausgangslage & Rat-Bürgermeister_in-Konstellation \\
\hline Vereinbarkeitssituation & $\bullet$ Verfügbarkeit \\
& $\bullet \quad$ Rückhalt \\
\hline
\end{tabular}

Parteipolitische Ausgangslage

Der für Bürgermeister_innen relevanteste Aspekt der parteipolitischen Ausgangslage in ihren Amtsstädten ist laut kommunalwissenschaftlicher Führungsforschung (u.a. Holtkamp 2008), wie sich die Mehrheitsverhältnisse im Rat zum eigenen Parteibuch verhalten - die Rat-Bürgermeister_in-Konstellation (RBK). Folgende RBK werden unterschieden: Bei klaren dauerhaften Mehrheiten liegt Homogenität vor, wenn Bürgermeister_in und Ratsmehrheit derselben Partei angehören bzw. wenn die Partei, der der_die Bürgermeister_in angehört, im Ratsmehrheitsbündnis vertreten ist. Kohabitation ist die Konstellation, wenn der_die Bürgermeister_in ein anderes Parteibuch hat als die Ratsmehrheit. Wechseln die Mehrheiten je nach anstehender Entscheidung, gibt es die RBK wechselnder Mehrheiten.

Die RBK versieht Bürgermeister_innen mit unterschiedlichen Chancen, Amtserfolg zu erlangen. Bogumil/Gehne/Holtkamp $(2003,28)$ schreiben den beiden RBK 
Homogenität und Kohabitation mit dem Begriff der Zwei-Klassen-Gesellschaft die Macht zu, die Regierungssituationen in solche der ersten Klasse und solche der zweiten Klasse einzuteilen. Denn die drei möglichen RBK bringen für die Bürgermeister_innen sehr unterschiedliche Handlungsspielräume mit sich, die sich aus ihrer mehrheitsbedingt je unterschiedlichen strukturellen Durchsetzungsfähigkeit im Rat ergeben.

Homogenität als attraktivste RBK zeigt sich in der Fallauswahl als zahlenmäßig bürgermeisterdominierte RBK (1:5). Kohabitation als unattraktivste RBK ist in der Fallauswahl ausschließlich Bürgermeisterinnen und keinem Bürgermeister (5:0) vorbehalten. Die RBK wechselnder Mehrheiten verteilt sich etwa gleich auf Bürgermeisterinnen und Bürgermeister (5:6). Die RBK stellt also hinsichtlich ihrer Verteilung eine deutlich geschlechtlich strukturierte Handlungsressource dar (Tab. 5).

Das genaue Zustandekommen von RBK nach Ratswahlen bleibt bislang zu sehr im Dunkeln, um einen belastbaren Zusammenhang zu Geschlecht herstellen zu können. Ein entscheidender Verteilungsmechanismus konnte jedoch ausgemacht werden: Die parteipolitische Großwetterlage der Amtsstadt in der Wahlsituation ist ein Vorbote der parteipolitischen Ausgangslage der Regierungssituation. Kandidat_innen mit sehr schlechten situativen Wahlchancen, nachweislich zumeist Kandidatinnen, erwartet also bei Wahlgewinn tendenziell die (sehr unattraktive) Kohabitation, während die (sehr attraktive) Homogenität bei sehr schlechten Wahlchancen so gut wie ausgeschlossen ist und damit eher Kandidaten vorbehalten bleibt.

\section{Vereinbarkeitssituation}

Die zweite Handlungsressource der Regierungssituation ist die Vereinbarkeitssituation der Bürgermeister_innen, also ihre außerberufliche Lebenssituation. Der Forschungsstand legt die Betrachtung der Vereinbarkeitssituation nahe, da er das Bürgermeister_in-Amt - wie auch andere politische Positionen - u.a. durch die Spielregel der Verfügbarkeit (u.a. Scholz 2004) und als 1,5 Personen-Beruf (Beck-Gernsheim 1980) mit bestimmten Rückhaltsanforderungen charakterisiert. Gleichzeitig weist er nach, dass Bürgermeisterinnen und Bürgermeister ihr Amt in unterschiedlichen Familien- bzw. Partnerschaftskonstellationen antreten (u.a. Bertelsmann Stiftung/ Deutscher Städtetag/Deutscher Städte- und Gemeindebund 2008). (Wie) spielen die jeweiligen außerberuflichen Lebenssituationen mit den Amtsanforderungen zusammen?

Die Verfügbarkeitsanforderung verlangt idealtypisch die Abwesenheit von Fürsorgeverpflichtungen. Wenn Fürsorgebedarf für Kinder und/oder ältere Angehörige besteht, dürfen daraus keine Fürsorgepflichten für die Bürgermeister_innen werden. Bürgermeisterinnen erreichen diese Verfügbarkeit vereinbarkeitsbiografisch zu anderen Konditionen: Sie gehen ohne Fürsorgepflichten in Kandidatur und Amt, weil es keinen hohen Fürsorgebedarf (mehr) zu decken gibt. Die Bürgermeister hingegen haben keine Fürsorgepflichten, weil es entweder auch in ihren außerberuflichen Le- 
benssituationen keine Fürsorgebedarfe (mehr) gibt oder sie die Fürsorgepflichten im Rahmen der Partnerschaftskonstellation des Karriere-Zuverdienerin-Modells an ihre Partnerinnen delegieren.

Die Rückhaltsanforderung beinhaltet idealtypisch, dass jemand Haus- und Versorgungsarbeit übernimmt, sowie die Bereitschaft der Familie, bei Repräsentationsterminen $\mathrm{zu}$ begleiten und den öffentlichen Zugriff auf Privates zu akzeptieren. Lediglich das Karriere-Zuverdiener_in-Modell ermöglicht diesen idealtypischen Rückhalt. In diesem Modell lebt keine einzige Bürgermeisterin, jedoch die meisten Bürgermeister. Aber auch dieses Modell ist kein Garant für uneingeschränkten Rückhalt. Dass die Zumutbarkeit von 1,5 Personen-Berufen hinterfragt gehört, zeigt sich darin, die Handlungsressource Vereinbarkeitssituation in uneingeschränkter Ausprägung lediglich bei zwei Bürgermeistern konstant und bei zwei Bürgermeistern phasenweise vorhanden ist. Bei allen anderen Bürgermeister_innen gibt es Abstriche.

Tabelle 5: Verteilung der Handlungsressourcen in der Regierungssituation auf die Bürgermeisterinnen und Bürgermeister

\begin{tabular}{|c|c|c|c|c|c|c|}
\hline \multirow[t]{3}{*}{$\begin{array}{l}\text { Handlungsres- } \\
\text { sourcen (HR) }\end{array}$} & \multicolumn{6}{|c|}{$\begin{array}{l}\text { Verteilung der Ausprägungen der Handlungsressourcen auf die Bürger- } \\
\text { meisterinnen (IN, N=11) und Bürgermeister (ER, } N=11 \text { ) }\end{array}$} \\
\hline & IN & ER & IN & ER & IN & ER \\
\hline & \multicolumn{2}{|c|}{ uneingeschränkte HR } & \multicolumn{2}{|c|}{ eingeschränkte HR } & \multicolumn{2}{|c|}{ keine HR } \\
\hline \multirow[t]{2}{*}{$\begin{array}{l}\text { parteipolitische } \\
\text { Ausgangslage }\end{array}$} & \multicolumn{2}{|c|}{ Homogenität } & \multicolumn{2}{|c|}{$\begin{array}{l}\text { wechselnde } \\
\text { Mehrheiten }\end{array}$} & \multicolumn{2}{|c|}{ Kohabitation } \\
\hline & 1 & 5 & 5 & 6 & 5 & 0 \\
\hline \multirow[t]{2}{*}{$\begin{array}{l}\text { Vereinbarkeits- } \\
\text { situation }\end{array}$} & \multicolumn{2}{|c|}{$\begin{array}{l}\text { uneingeschränkte Ver- } \\
\text { fügbarkeit und unein- } \\
\text { geschränkter Rückhalt }\end{array}$} & \multicolumn{2}{|c|}{$\begin{array}{l}\text { Verfügbarkeit, einge- } \\
\text { schränkter Rückhalt }\end{array}$} & \multicolumn{2}{|c|}{$\begin{array}{l}\text { eingeschränkte Ver- } \\
\text { fügbarkeit und einge- } \\
\text { schränkter Rückhalt }\end{array}$} \\
\hline & 0 & $2(2)^{*}$ & $9(2)$ & 7 (2) & (2) & 0 \\
\hline
\end{tabular}

barkeit und/oder Rückhalt phasenweise gewechselt hat.

Den ersten Ergebnisstrang zusammenfassend, lässt sich empirisch ein deutlicher geschlechterhierarchischer Einfluss auf die Verteilung der Handlungsressourcen nachzeichnen. Die Mechanismen, die diese Verteilungen hervorbringen, korrespondieren zudem mit den drei Gender-Dimensionen (Pimminger 2012) - es sind also geschlechterbedingte nachteilige Ausgangslagen.

Dem steht jedoch der zweite Ergebnisstrang gegenüber: Der tatsächliche Wahlerfolg und Amtserfolg, der sich in der Erstwahl und in mindestens einer Wiederwahl zeigt, unterscheidet sich nicht zwischen den Kandidatinnen und Kandidaten bzw. Bürgermeisterinnen und Bürgermeistern. Wie passt das zueinander? 
Einordnung: ,Männliche' Standards und Ansätze für ihre Aushebelung

Folgende Deutung (unter anderen) vermag diese Diskrepanz erklären: Die Handlungsressourcen statten lediglich mit Kapital aus, dessen Ausprägungen abgestufte Chancen auf Erfolg mit sich bringen. In der Erstwahl und Wiederwahl zeigt sich dann der tatsächliche Erfolg. Es scheint denkbar, dass ,männliche‘ Standards zwar für die Zuweisung von Handlungsressourcen seitens der Ortsparteien und damit für die Chancen auf Erfolg eine Rolle spielen, jedoch nicht bzw. deutlich weniger für den tatsächlichen Erfolg.

Gender erzeugt in Form von Geschlechternorm, Geschlechterordnung und gesellschaftlicher Geschlechterstruktur im Grunde genommen artifizielle Bewertungsstandards, die die Verteilung(smechanismen) steuern. Dagegen werden Wahlerfolg und Amtserfolg jenseits dieser Artefakte vielleicht sachlicher bzw. individueller und damit vergleichsweise Gender-unabhängiger seitens der Wähler_innen zugesprochen. Kurzum: Möglicherweise werden Handlungsressourcen eher mit starkem gender bias entlang, männlicher' Standards verteilt, dagegen Wahlerfolg und Amtserfolg mit geringe(re)m gender bias entlang objektiv(er)er Standards.

Besonders anfällig für eine artifizielle Bewertung scheinen die Handlungsressourcen, die stark normativ geprägt sind: ${ }^{15}$

- die Eignung(sbeurteilung), die wesentlich auf den heuristischen Eignungskriterien des KandidatEN-Profils basiert und

- die Vereinbarkeitssituation, die wesentlich auf der idealtypischen Verfügbarkeits- und Rückhaltsanforderung des Bürgermeister_in-Amtes beruht.

Der Erfolg der Kandidatinnen und der Bürgermeisterinnen, obwohl sie weder das KandidatEN-Profil noch die idealtypische Verfügbarkeits- und Rückhaltsanforderung uneingeschränkt erfüllen, kann dahingehend gedeutet werden, dass diese ,männlichen' Standards ihre Legitimation verloren haben.

\section{Gleiche Handlungsressourcen und endlich Gleichheit! Für einen Kulturwandel in der Politik}

Empirisch nachzuzeichnen, wer warum mit welchen Handlungsressourcen ausgestattet wird, erschließt die ungleichen Bedingungen nominierter Kandidatinnen und gewählter Bürgermeisterinnen im Vergleich zu ihren männlichen Amtskollegen. Aus der qualitativ angelegten Forschung leiten sich zweierlei Forschungsbedarfe ab: zum einen zur Reichweite und Übertragbarkeit mit der Frage, ob diese Handlungsressourcen und die geschlechtliche Strukturierung ihrer Verteilung(smechanismen) auch für Bürgermeister_innen anderer Bundesländer, Gemeindegrößen und Parteien bzw. ohne Parteibuch gelten. ${ }^{16}$ 
Zum anderen sollten die beiden zentralen ausschlussrelevanten Eigenlogiken des kommunalpolitischen Feldes - die Eignung(sbeurteilung) entlang des KandidatENProfils und die Verfügbarkeits- und Rückhaltsanforderung des Amtes - weiter hinterfragt werden. ${ }^{17}$ Denn: Die herkömmliche Männer und ,Männlichkeit' privilegierende Beurteilung von Eignung sowie Definition von Amtsanforderungen behindert eine konsequente Bestenauslese und angemessene Unterstützung des kommunalpolitischen Spitzenpersonals - und problematisiert damit das politische Geschäft nicht nur aus gleichstellungspolitischer Perspektive. Ein grundlegender Kulturwandel muss daher die ,männlichen ' Standards zum Gegenstand machen, die in der Politik immer wieder den „Normalfall Mann“ und „Ausnahmefall Frau“ (re)produzieren. Erfreulich, wenn die Politik selbst erkennt, dass hier in ihrem ureigensten Interesse Handlungsbedarf besteht. Die zentrale Erkenntnis, die zur gesetzlichen Regulierung von Wissenschaft, Verwaltung und zuletzt auch der Privatwirtschaft führte, war jedoch, dass die geschlechterparitätische Besetzung von Entscheidungs- und Führungspositionen nicht funktioniert, wenn sie allein dem good will der Akteur_innen überlassen wird. ${ }^{18}$ Also gilt auch für die Politik: Ohne Paritätsgesetz kein Kulturwandel - ohne Kulturwandel keine Parität in der Politik (ausführlicher dazu siehe Lukoschat/Belschner 2017; Kletzing 2017b, 2016; Kletzing/Bonk 2018)!

Vor 100 Jahren ging es darum, dass Frauen als Wählerinnen und Gewählte überhaupt an Politik und Gesellschaft partizipieren durften. Das hat die Einführung des Frauenwahlrechts geschafft. Heute geht es um die gleichberechtigte Partizipation von Frauen an Politik und Gesellschaft: gleichberechtigt im Zugang zu Positionen und gleichberechtigt in den Bedingungen, um in diesen Positionen erfolgreich sein zu können. Das kann nur ein Paritätsgesetz schaffen. Dies zu erstreiten und zu erkämpfen ist die Aufgabe für das zweite Jahrhundert Frauenwahlrecht - wenngleich das hoffentlich keine 100 Jahre mehr dauert!

\section{Anmerkungen}

1 Die prekäre Datenlage zu Frauen in der Politik ist ein Missstand, der den Missstand der Unterrepräsentanz von Frauen in der Politik noch befeuert. Die Datenbeschaffung und -aktualisierung, insbesondere auf der kommunalen Ebene, stellt sich als sehr aufwändig dar. Die Zahlen basieren daher auf unterschiedlichen Quellen (BMFSFJ 2017; Lukoschat/Belschner 2017) und nicht selten auf eigenen Auszählungen.

2 .Weiblich(keit)' und ,Männlich(keit) ' werden im Aufsatz in einfache Anführungsstriche gesetzt, weil sie Konstrukte sind, die jedoch sehr reale Gestalt annehmen. Ausdruck dieser Zwischenstellung sind die einfachen Anführungsstriche.

3 Die Fallauswahl umfasste ausschließlich hauptamtliche, keine ehrenamtlichen Bürgermeister_innen - sprachökonomisch im Aufsatz als „Bürgermeister_innen“ bezeichnet.

4 Damit folgt die Untersuchung den lauter werdenden Stimmen auch anderer politikwissenschaftlicher Grenzgänger_innen (u.a. Holtkamp/Schnittke 2010; Geißel 2004), dass nur der Brückenschlag zwischen Gender- und Mainstream-Forschung nachhaltige Erkenntnisse für die jeweiligen Forschungsinteressen verspricht.

5 Weil Pimminger (2012) eine umfassende Analyse und Integration bisheriger Frauen- und Geschlechterforschung vorgenommen hat, rechtfertigt sich der vornehmliche theoretische Fokus auf ihre Arbeit. 
6 Double bind steht für den „doppelten Standard“, der an Frauen in männlich kodierten Handlungssituationen (z.B. Führungspositionen, Politik) angelegt wird, widersprüchlichen bis unvereinbaren ,weiblichen 'und 'männlichen' Erwartungen entsprechen zu müssen.

7 Die neben Bertelsmann Stiftung/Deutscher Städtetag/Deutscher Städte- und Gemeindebund (2008) zweite geschlechtervergleichende Bürgermeister_innen-Studie von Lukoschat/Belschner (2014) lag erst nach Konzeptualisierung und Datenerhebung dieser Forschung vor und konnte daher erst in die Datenauswertung einfließen.

8 Lediglich Unterschiede in Form sehr latenter Ausschlüsse von Kandidatinnen bzw. Bürgermeisterinnen, wie sie Meyer $(1997,359)$ als „Widerstände und subtilere Abwehrstrategien“ beschreibt, wurden erwartet.

9 Die Fallauswahl entspricht einem most similar cases-design: Die Gemeindegröße, das Bundesland und die Partei(zugehörigkeit) wurden als Drittvariablen vereinheitlicht, nur die Variable Genusgruppe wurde systematisch variiert. Dadurch wird die Verallgemeinerbarkeit der Ergebnisse auf von den vereinheitlichten Drittvariablen abweichende Kontexte zwar eingeschränkt, jedoch der Erkenntnisgewinn hinsichtlich der interessierenden Variable Geschlecht maximiert.

10 Alle Erhebungs- und Auswertungsinstrumente befinden sich vollständig im Anhang von Kletzing (2017a).

11 Lediglich ein Bürgermeister ist von vornherein nur für eine Wahlperiode angetreten. Alle anderen Untersuchten wurden spätestens in der Bürgermeister_in-Wahl 2014/15 mindestens einmal wiedergewählt.

12 Jede Bewertung von Eignung ist auch von Subjektivität gefärbt. Um dieser Nichthintergehbarkeit des Subjektiven Rechnung zu tragen, wird die Handlungsressource begrifflich als "Eignung(sbeurteilung)" gefasst.

13 Die männliche Schreibweise „KandidatEN-Profil“ soll zum einen explizieren, dass die statistische Mehrheit, deren Merkmale hier beschrieben werden, Bürgermeister waren und anzunehmen ist, dass mögliche biografische Spezifika von Bürgermeisterinnen als statistische Minderheiten in der soziodemografischen Beschreibung verschwinden. Zum anderen bildet der Begriff auch den Androzentrismus der Eignungskriterien ab.

14 Inwiefern sich Gender in den Werdegängen/Lebenszusammenhängen der Befragten zeigt, war eine eigene Fragestellung der diesem Beitrag zugrundeliegende Dissertation. Dafür wurde eine eigene Indikatorik (Lebensalter, politisch-beruflicher Werdegang, lokale Bindung, Familienverhältnisse) entwickelt und u.a. für die Messung der Eignung(sbeurteilung) verwendet.

15 Gleichzeitig stellen sich diese beiden normativen Grundlagen bzw. die aus ihnen hervorgehenden Ausprägungen der Handlungsressourcen als besonders wirkmächtig heraus, weil sie auch auf die anderen Handlungsressourcen ausstrahlen. Damit sind sie maßgeblich für die Verteilung(smechanismen) der Handlungsressourcen insgesamt.

16 Insbesondere den ausschlussrelevanten Feinheiten in den politisch-beruflichen Werdegängen sowie bzgl. der zahlenmäßigen Verteilung der Bürgermeisterinnen und Bürgermeister auf die drei Rat-Bürgermeister_in-Konstellationen sollte repräsentativ für die Grundgesamtheit aller Bürgermeister_innen nachgegangen werden.

17 Erste Ansätze, wie jenseits , männlicher 'Standards die Eignungskriterien in Form eines Bürgermeister_in-Profils und die Verfügbarkeits- und Rückhaltsanforderung im Umfang eines 1 Person-Berufs definiert werden könnten, finden sich in Kletzing (2017a).

18 Nur gesetzliche Regulierung kann den eigentlich notwendigen Kulturwandel anstoßen. „Dieses Gesetz bewirkt einen Kulturwandel", so die damalige Bundesfrauenministerin Schwesig in ihrer Rede, als sie den Gesetzentwurf für die Privatwirtschaft vorlegte (Schwesig 2015). 


\section{Literatur}

Andersen, Uwe/Bovermann, Rainer (Hg.), 2002: Im Westen was Neues. Kommunalwahl 1999 in NRW. Opladen.

Beck-Gernsheim, Elisabeth, 1980: Das halbierte Leben. Männerwelt Beruf, Frauenwelt Familie. Frankfurt/M.

Bertelsmann Stiftung/Deutscher Städtetag/Deutscher Städte- und Gemeindebund (Hg.), 2008: Beruf Bürgermeister/in. Eine Bestandsaufnahme für Deutschland. Ergebnisse einer repräsentativen Befragung von Bürgermeisterinnen und Bürgermeistern. Gütersloh. Internet: http:// www.bertelsmann-stiftung.de/fileadmin/files/BSt/Presse/imported/downloads/xcms_bst_ dms_23926_23927_2.pdf (1.8.2018).

Bogumil, Jörg/Gehne, David H./Holtkamp, Lars, 2003: Gestaltungsfreiheit im Süden größer. In: Städte- und Gemeinderat. (10), 26-28.

Bogumil, Jörg/Heinelt, Hubert (Hg.), 2005: Bürgermeister in Deutschland. Politikwissenschaftliche Studien zu direkt gewählten Bürgermeistern. Wiesbaden.

Bogumil, Jörg/Holtkamp, Lars, 2005: Die Machtposition der Bürgermeister im Vergleich zwischen Baden-Württemberg und NRW. In: Bogumil, Jörg/Heinelt, Hubert (Hg.): Bürgermeister in Deutschland. Politikwissenschaftliche Studien zu direkt gewählten Bürgermeistern. Wiesbaden, 33-85.

Bundesministerium für Familie, Senioren, Frauen und Jugend, 2017: 3. Atlas zur Gleichstellung von Frauen und Männern in Deutschland. Internet: https://www.bundesregierung.de/Content/Infomaterial/BMFSFJ/3_-Atlas-zur-Gleichstellung-von-Frauen-und-M\%C3\%A4nnern-inDeutschland-deutsch_BMFSFJ16-114010.html (30.6.18).

Gehne, David H., 2002: Die neuen Bürgermeister. In: Andersen, Uwe/Bovermann, Rainer (Hg.): Im Westen was Neues. Kommunalwahl 1999 in NRW. Opladen, 221-233.

Gehne, David H., 2008: Bürgermeisterwahlen in Nordrhein-Westfalen. Wiesbaden.

Geißel, Brigitte, 2004: Konflikte um Definitionen und Konzepte in der genderorientierten und Mainstream-Partizipationsforschung. Ein Literaturüberblick. Discussion Paper Nr. SP IV 2004403, Wissenschaftszentrum Berlin für Sozialforschung, Internet: https://www.ssoar.info/ssoar/ handle/document/11813 (1.8.18).

Grasselt, Nico/Korte, Karl-Rudolph, 2008: Führung in Politik und Wirtschaft. Wiesbaden.

Helms, Ludger, 2008: „Political Leadership“: Perspektiven und Befunde der vergleichenden Politikwissenschaft. In: Zimmer, Annette/Jankowitsch, Regina (Hg.): Political Leadership. Annäherungen aus Wissenschaft und Praxis. Berlin, München, Brüssel, 15-42.

Holtkamp, Lars, 2008: Kommunale Konkordanz- und Konkurrenzdemokratie. Parteien und Bürgermeister in der repräsentativen Demokratie. Wiesbaden.

Holtkamp, Lars/Schnittke, Sonja, 2010: Die Hälfte der Macht im Visier - Der Einfluss von Institutionen und Parteien auf die politische Repräsentation von Frauen. Bielefeld, Internet: https://www. fernuni-hagen.de/polis/lg4/projekte/kommunalpolitik.shtml (1.8.18).

Kletzing, Uta, 2016: Agenda-Setting for a German parity law. Comments Paper im Rahmen der Tagung..Women in political decision-making“, EU Mutual Learning Programme in Gender Equality, Internet: http://ec.europa.eu/justice/gender-equality/files/exchange_of_good_practice_si/ de_comments_paper_si_2016_en.pdf (10.12.17).

Kletzing, Uta, 2017a: Die ausgeschlossenen Eingeschlossenen. Wahlsituation und Regierungssituation von Bürgermeisterinnen und Bürgermeistern im Geschlechtervergleich, Fernuniversität in Hagen. Internet: https://ub-deposit.fernuni-hagen.de/servlets/MCRFileNodeServlet/mir_derivate_00001093/Diss_Kletzing_Eingeschlossenen_2017.pdf (30.6.18).

Kletzing, Uta, 2017b: Mehr Frauen für die Politik gewinnen - Ein Interview mit Dr. Uta Kletzing. MuP-Interview, Oktober 2017. Internet: https://www.fes-mup.de/files/mup/pdf/interviews/Interview_Kletzing.pdf (10.12.17). 
Kletzing, Uta/Bonk, Christiane, 2018: Eine (un)endliche Geschichte? Frauenwahlrecht damals und heute. In: Neue Gesellschaft Frankfurter Hefte. Berlin.

Kletzing, Uta/Lukoschat, Helga, 2010: Engagiert vor Ort - Wege und Erfahrungen von Kommunalpolitikerinnen. Kurzfassung, hg. vom Bundesministerium für Familie, Senioren, Frauen und Jugend. Internet: http://www.bmfsfj.de/RedaktionBMFSFJ/Broschuerenstelle/Pdf-Anlagen/Engagiert-vor-Ort-Kurzfassung, property=pdf, bereich=bmfsfj, sprache=de, $r w b=t r u e . p d f ~(1.8 .2018)$.

Krell, Gertraude (Hg.), 2004a: Chancengleichheit durch Personalpolitik. Gleichstellung von Frauen und Männern in Unternehmen und Verwaltungen. Rechtliche Regelungen, Problemanalysen, Lösungen. Wiesbaden.

Krell, Gertraude, 2004b: „Vorteile eines neuen, weiblichen Führungsstils“: Ideologiekritik und Diskursanalyse. In: Krell, Gertraude (Hg.): Chancengleichheit durch Personalpolitik. Gleichstellung von Frauen und Männern in Unternehmen und Verwaltungen. Rechtliche Regelungen, Problemanalysen, Lösungen. Wiesbaden, 377-392.

Lukoschat, Helga/Belschner, Jana, 2014: Frauen führen Kommunen. Eine Untersuchung zu Bürgermeisterinnen und Bürgermeisterin in Ost und West. Berlin. Internet: https://www.frauen-macht-politik.de/.../P_Frauen-Fuehren-Kommunen_Studie.pdf (1.8.18).

Lukoschat, Helga/Belschner, Jana, 2017: Macht zu gleichen Teilen. Ein Wegweiser zu Parität in der Politik. Internet: https://www.frauen-macht-politik.de/fileadmin/Dokumente/Wegweiser_ zu_Paritaet_in_der_Politik_web.pdf (17.3.18).

Mayring, Philipp, 2003: Qualitative Inhaltsanalyse. Grundlagen und Techniken. Stuttgart.

Mayntz, Renate/Scharpf, Fritz (Hg.), 1995: Gesellschaftliche Selbstregelung und politische Steuerung. Frankfurt/M.

Meyer, Birgit, 1997: Frauen im Männerbund. Politikerinnen in Führungspositionen von der Nachkriegszeit bis heute. Frankfurt/M.

Pimminger, Irene (2012): Was bedeutet Geschlechtergerechtigkeit? Normative Klärung und soziologische Konkretisierung. Opladen, Berlin et al.

Schaeffer-Hegel, Barbara/Foster, Helga/Lukoschat, Helga/Mersmann, Rita/Ude, Silke/Weber, Ulla, 1998: Frauen mit Macht. Zum Wandel der politischen Kultur durch die Präsenz von Frauen in Führungspositionen. Pfaffenweiler.

Scharpf, Fritz, 2000: Interaktionsformen. Akteurzentrierter Institutionalismus in der Politikforschung. Wiesbaden.

Scholz, Anja, 2004: Oberbürgermeisterinnen in Deutschland. Zum Erfolg weiblicher Führungspersönlichkeiten. Wiesbaden.

Schwesig, Manuela, 2015: Bundestagsrede zur Frauenquote. Internet: https://www.bmfsfj.de/ bmfsfj/mediathek/bundestagsrede-von-manuela-schwesig-zur-frauenquote/83794 (1.8.18).

Wetterer, Angelika, 2010: Konstruktion von Geschlecht: Reproduktionsweisen der Zweigeschlechtlichkeit. In: Becker, Ruth/Kortendiek, Beate (Hg.): Handbuch Frauen- und Geschlechterforschung. Theorie, Methoden, Empirie. Wiesbaden, 126-136.

Zimmer, Annette/Jankowitsch, Regina (Hg.), 2008: Political Leadership. Annäherungen aus Wissenschaft und Praxis. Berlin, München et al. 


\title{
Gendered Segregation in Danish Standing Parliamentary Committees 1990-2015'
}

\author{
CHRISTINA FIIG
}

\section{Introduction}

The decade of the 2010s is characterised as a European "suffragette moment" owing to celebrations of centenaries of women's parliamentary enfranchisement in Norway (2013), Denmark (2015), Austria, Germany and Great Britain (2018), the Netherlands (2019) and Sweden (2021). Winning the vote meant overcoming traditional norms that varied from culture to culture but nearly always excluded women from politics (Inglehart/Norris/Welzel 2002, 321). Denmark was among the first countries to achieve female enfranchisement to municipalities (1908) and to the national parliament (1915), thereby gaining a leading status in terms of political gender equality, women's rights and citizenship. 100 years later, the Danish case gives grounds for reflections on gender balance, horizontal and vertical gender segregation of parliamentary politics, and the positions occupied by women in national parliaments and power. The case contributes to a debate about "the next step" as it illustrates that the right to vote and to be elected is not sufficient to promote broad political representation - even in a society that considers itself relatively equal in terms of gender.

In the following, I focus on representation in parliamentary core positions: women's and men's committee membership and their tenancy as committee chairs and vicechairs in the Danish parliament, the Folketing. ${ }^{2}$ In other words, I examine the horizontal and the vertical gendered segregation of standing committees over 25 years (1990-2015). The fact that standing committees are influential motivates a comprehensive analysis of changes over time (Wängnerud 2015, 62).

Parliamentary committees are often described as the "epicentre of parliamentary influence" (Murray/Sénac 2018, 310) and as important for efficient law-making and oppositional control (Hansen 2010). They are a crucial resource in the legislative system. Moreover, committee positions constitute a stepping stone in individual parliamentarians' (MPs') political careers as they gain visibility and expertise in specific policy areas (Pansardi/Vercesi 2017, 63). Analyses of women and men in parliamentary committees draw a critical picture of gender segregation in different committees and expose a tendency to assign committee posts along traditional gender lines. For the Danish case, two studies found a horizontal and vertical segregation in standing parliamentary committees (Refsgaard 1990) and in committees in local municipalities (Baekgaard/Kjaer 2012). Sweden displays a decline in horizontal and vertical segregation in parliamentary committees (Bolzendahl 2014; Wängnerud 2009; 2015).

This article analyses the proportion of female and male MPs in standing Danish parliamentary committees based on an explorative study. It discusses two questions "100 years after enfranchisement" in the Danish context, where almost $40 \%$ of MPs 
are female: (1) What is the gendered distribution of seats and chairs in Danish parliamentary committees over a 25 -year period? (2) What can explain these gender patterns? The analysis does not consider the prestige of the different parliamentary committees or the seniority of the individual MPs, their party affiliation, or individual preferences in terms of committee membership.

The gendered segregation of parliamentary committees is defined as follows. Vertical division of labour concerns men's and women's positions in political hierarchies; horizontal division of labour concerns the various policy areas in which women and men work (Raaum 1995, 31-32; Dahlerup/Leyennar 2013).

The article proceeds as follows. I first illustrate the Nordic context as a background for the Danish case. Then, I review the literature and the theoretical approaches that are relevant for understanding the analysis. Next, I present the methodological framework and my empirical findings. In the final section, I discuss the findings.

\section{The Danish Case in a Nordic Context}

Internationally, the Nordic countries (Denmark, Finland, Iceland, Norway, Sweden) are often considered a homogenous region with a high degree of political gender equality. While, indeed, this seems to be true in general terms, a closer look reveals distinct differences (Bergqvist et al. 1999). One common characteristic is that women's entrance into politics is a post-war phenomenon that has changed women's relationship to democracy, power and influence as well as the entire political landscape (Karvonen/Selle 1995). In the early 1970s, women were virtually absent from Scandinavian politics, but a decade later, their political presence was very apparent (Raaum 1995, 25). The Nordic countries became the first region in the world to pass 30\%, which is considered a major threshold (Bergqvist et al. 1999; Dahlerup 2018, 190). However, the pace and direction of gender equality and women's representation in Nordic politics differ in the individual countries. According to Nordic gender research, being democratically elected as an MP constitutes the main channel of influence for women in the Nordic countries (Bergqvist et al. 1999; Dahlerup 1988; Fiig 2009; Hernes 1987; Raaum 1995; Skjeie 1992; Togeby 1995). The analysis of women's mobilisation, participation and representation in politics points to a range of connected background factors, such as demographic changes, growth of women's resources, government policies, and the influence of the women's movement (Karvonen/Selle 1995). Furthermore, high levels of economic development correlate positively with a high number of elected women (Wängnerud 2009, 56).

The picture of women in elite positions in the Nordic countries is not all rosy. Among the obstacles to female politicians are hostile reactions to women, working conditions that are incompatible with family responsibilities, and the existence of maledominated networks (Wängnerud 2009, 60; Celis/Lovenduski 2018). This resonates with the fact that female Swedish MPs are less satisfied than their male colleagues with the working conditions in parliamentary party groups (Wängnerud 2015, 78). 
Danish female MPs feel discriminated in media representations, both in the regional and the national press (Jensen 2004; Moustgaard 2004). Outside parliament and politics, white majority men predominantly occupy the powerful top positions in the Scandinavian societal hierarchies (Christiansen/Møller/Togeby 2001; Skjeie/Teigen 2003).

In the Danish case, certain characteristics stand out. The proportion of female MPs has risen from $16 \%$ in 1975 to $30 \%$ in $1987,33 \%$ in $1994-1998,37 \%$ in $1998,38 \%$ in $2001,37 \%$ in $2005,38 \%$ in $2007,39 \%$ in the 2011 -election and $37 \%$ in the latest election, 2015. In the 2000s, women's political representation in parliament stagnated just below 40\% (Dahlerup 2018). In 2011, Denmark's first female prime minister headed a centre-left government, which lost at the following election in 2015 (ibid., 191). Previous parliamentary studies have shown that female MPs are often more concerned with gender equality than their male colleagues (ibid.; Holli/ Harder 2016; Wängnerud 2009).

Dahlerup's survey of Danish parliamentarians' perceptions of gender equality principles and policies in 2015 confirms this point (perception is defined as the way something is regarded, understood or interpreted) $(2018,193)$. Her findings document a gender gap in female and male MPs' active engagement in gender equality politics, with female MPs being more active than their male colleagues (ibid., 206). Moreover, Dahlerup's survey illustrates a left-right cleavage in attitudes towards whether gender equality has been achieved in Denmark. Left-leaning politicians do not find that gender equality has been achieved, whereas right-leaning politicians find that it has.

\section{Gendered Segregation of Parliamentary Committees: Findings and Explanations}

Research on gender and standing parliamentary committees is challenged by a lack of agreement about the reasons for the gender composition in committees (Murray/ Sénac 2018, 311). However, several of these studies are based on data from countries with a different history of women's political rights and citizenship than the Nordic countries. These studies paint a picture of horizontal and vertical gender segregation in parliamentary committees. Women tend to be under-represented in influential positions and typically sit in committees on cultural and social issues, and men are present in committees on the economy and international affairs (Carroll 2008; Frisch//Kelly 2003; Heath/Schwindt-Bayer/Taylor-Robinson 2005; Murray/Sénac 2018; Pansardi/Vercesi 2017; Thomas 1994). There is a tendency to assign committee posts along traditional gender lines in a range of parliamentary contexts. The division of labour, both in committee membership and leadership, tends to favour men for instrumental issues like foreign affairs, transport, finance and taxes; and women for social issues, culture, health, human rights, rules and services (Bolzendahl 2014, 870). Several Nordic studies can help us contextualise the Danish case. In 
Refsgaard's study (1990) of the standing parliamentary committees 1965-1988 in Denmark and women's numerical representation, she concluded that in the 1980s the assignment of women to committees and their representation were almost proportionally equal to that of men. However, she did identify a gendered horizontal distribution of committee seats. Committees with general economic functions had a low representation of women, whereas committees focusing on social issues had a high representation of women. The same tendency was documented in a study of committee assignments in the 98 Danish municipalities after the 2009 local election (Baekgaard/Kjaer 2012). They found that committee assignments are not gender neutral. Female local politicians were under-represented in the powerful finance committee and there were significantly more women in committees on children's issues than in technical committees. Baekgaard and Kjaer concluded that a gendered difference - vertical as well as horizontal - clearly existed in Danish local government committees (ibid., 471). They also concluded that women and men sit on different committees primarily because they have different preferences (ibid., 479).

Hansen's study (2010) of committee assignment politics in the Danish parliament 1994-2007 discusses a ranking of committee importance based on the ministerial portfolio to which committees are related. Hansen showed that depending on the party in question, MPs with certain characteristics are more likely to be assigned to higher-ranked committees than others regardless of gender. Hansen concluded that sectorisation has been reduced across all committees and that seniority has a significant, positive influence on committee assignments for some parties. In the Liberals, the Socialist People's Party and the Social Democrats, being a woman increased the possibility of being assigned to a higher-ranking committee (ibid., 394, 398).

Wängnerud's studies $(2009 ; 2015)$ of Swedish parliamentary committees 1970-1996 are of particular interest as Sweden and Denmark are often compared. The overall picture is that the division between male and female policy areas was especially clear-cut in the 1980s and 1990s, and that the 1994 election was followed by a notable change as previous gender patterns almost disappeared (Wängnerud 2009, 61). There is evidence of increasing gender balance in terms of committee assignments and thus less gendered segregation in the Swedish parliament.

Some studies have sought to provide explanations for the gendered segregation of parliamentary committees. In general terms, these are placed on three levels: the political institution, the party and the individual politician (Heath/Schwindt-Bayer/ Taylor-Robinson 2005, 422). Further explanations point to choice and self-selection (Frisch/Kelly 2003), and discrimination and stereotyping (Carroll 2008, quoted in Baekgaard/Kjaer 2012, 468). Recent research has argued that the increased influence of an institutional approach in research on women, gender and politics has made the issue of choice versus coercion partly outdated, and that it is problematic to overemphasise the importance of factors relating to individuals. Wängnerud proposes an approach that moves back and forth between the three levels (2015, 60-61). 
Bolzendahl used a feminist institutionalist framework to study the gendered organisation of legislative committees in Germany, Sweden and the United States over 40 years. She argued that gender is embedded in political institutions, that gender operates beyond the individual level and can be seen as an institution in itself (2014, 848). Her institutional approach suggests that there is a risk of overemphasising individual factors, such as women's background, preferences and interaction styles (ibid.). Based on her findings, Bolzendahl distinguishes between three models of legislative committee systems and gendered organizations: Germany as a "polarized gendered organization", the United States as a "masculine dominance gendered organization", and Sweden as an "egalitarian-trending gendered organization" where traditional notions of gender are not inscribed in the structure of the committee system (ibid., 869). It would be reasonable to expect that the standing committees in the Danish and Swedish parliaments would resemble each other. However, women's representation in the Danish parliament seems to have stagnated at just below $40 \%$ (Dahlerup 2013; 2018), which is not the case in Sweden.

Murray and Sénac's (2018) study of gender gaps in French legislative committees employs expertise, seniority and gender stereotyping as explanations for women's relative over- or under-representation in each parliamentary committee for the 2009 and 2012 elections. Their study documents that the expertise accrued by legislators during their careers does influence their roles in parliament (ibid.). Stereotyping is amplified in parliament as small gaps in knowledge translate into larger gaps in experience and even larger gaps in committee allocation (ibid.). Murray and Sénac regard their findings as part of a wider, worrying trend of subtle discrimination against women throughout the political process (ibid., 328).

Finally, the time-lag hypothesis adds a valuable point, implying that both vertical and horizontal segregation decline over time and that the relative under-representation of women will also decline over time (Raaum 1995, 31, 47). The time-lag hypothesis predicts that women's representation will increase in a constant and perhaps even irreversible process towards permanent gender balance (Dahlerup/Leyennar 2013, 2). If the hypothesis is valid, a period of 25 years can be expected to cause a decline in both types of segregation in the Danish case.

\section{The Structure and Function of the Danish Parliament}

In order to describe the structure and function of the Danish parliament, I rely on legislative studies (Hansen 2010; Holli/Harder 2016; Mattson/Strøm 1995). Denmark is a parliamentary democracy with proportional representation. The parliament has 179 members, and the parties are key actors in the Danish parliament (Hansen 2010, 382). They are perceived as highly powerful by the MPs (Jensen 2004, 113). Parties are gatekeepers to political office and play an exclusive role in determining committee assignments (Norris/Lovenduski 1995, quoted in Pansardi/Vercesi 2017, 63). Danish parliamentary committees and the parliamentary design enjoy a large degree 
of stability (Hansen 2010). As in any modern legislature, the committees play an important role in the day-to-day life of the parliament (ibid., 383) and MPs perceive committees as very powerful (Jensen 2004, 113).

Legislative power can be conceptualised as having two dimensions: drafting authority and agenda control. Danish parliamentary committees have high agenda control but negligible authority in drafting legislation (Mattson/Strøm 1995, quoted in Holli/ Harder 2016, 3-4). Parliamentary committees have the power to call the relevant minister to appear before them at any time to ask questions concerning the legislation they are currently considering, and this is done frequently (Hansen 2010, 384). Committee members are appointed by the parties at the beginning of each parliamentary session (lasting from the first Tuesday in October until June 5) or immediately after an election. The allocation of seats between the parties is governed by the Danish Constitution ( $§ 52)$, which states that all elections to commissions and committees must be based on proportionality (Hansen 2010). Chairs and vice-chairs are elected by the committee members. MPs who are not ministers almost always sit on at least one committee (Hansen 2010,383). The standing committees generally mirror ministerial portfolios. In Hansen's analysis of committee assignment politics in the Danish parliament, he emphasises that three standing committees are especially important: Foreign Affairs, Finance and European Affairs (ibid., 384). Their importance is rooted in the constitutional mandate (foreign affairs), the committee's mandate (finance) and a rise in political importance (European affairs).

The Danish parliament has had varying numbers of standing parliamentary committees and ad hoc committees. Since 2011, most of the standing committees have 29 members compared to 17 previously. In 2011, the Danish parliament decided to form the Gender Equality Committee - before this date, gender equality was addressed by the Political-Economics Committee (Holli/Harder 2016, 799). Denmark has no legislative quotas for achieving gender balance in the political system.

\section{Methodological Framework}

My research design combines insights from existing studies of parliamentary committees (Hallberg 20033; Raaum 1995, Refsgaard 1990) and research on gender, power and politics (Dahlerup/Leyenaar 2013). The research design makes it possible to map the vertical and horizontal segregation, to track developments over time in a longitudinal study, and to draw conclusions about trends at different points in time over 25 years.

In order to analyse the distribution of female and male committee positions over a long period, I collected an original data set of seats, chairs and vice-chairs in Danish parliamentary committees for the period 1990-2015. This period is interesting because the average percentage of female MPs was 36-37\% and women's representation in parliamentary politics stagnated slightly below $40 \%$ (Dahlerup 2018). I compiled gender-disaggregated data of committee members for five selected par- 
liamentary years (1991/1992, 1997/1998, 2003/2004, 2009/2010 and 2014/2015). Committee membership before 2008 was recorded based on the yearbook of the Danish parliament. Data after 2008 was obtained via the parliamentary website (see also Bolzendahl 2014, 853). Committee membership was coded for the second plenum of each parliamentary session in October when committee membership for the coming session is published. ${ }^{4}$

My classification of committees is inspired by Hallberg (2003) and Dahlerup and Leyenaar $(2013,10)$, I constructed a classification that reflects that the proportion of female MPs in the Danish parliament was 35-36\% throughout 1990-2015. In principle, I would therefore expect each committee to contain 35-40\% female MPs and $60-65 \%$ male MPs to reflect the numerical representation in the parliament.

Classification of Danish committees:

- Over-representation of women (>40\%)

- Reflexive representation (30-40\% women)

- Under-representation of women $(<30 \%)^{5}$

Since there are 33\%- 39\% female MPs (on average 36-37\%) in the Danish parliament in the analysed period, they would be over-represented if their share in committees were above $40 \%$ and under-represented if their share were below $30 \%$. The terminology of over- and under-representation of women is inspired by Murray and Sénac (2018) and Pansardi and Vercesi (2017). ${ }^{6}$ The term "reflexive representation" describes a type of committee whose gender composition reflects the gender composition of the Danish parliament in the analysed period (30-40\%). ${ }^{7}$

\section{Empirical Findings}

The data reveals that female parliamentarians sit on all committees and act as chairs and vice-chairs as they do in the Swedish parliament (Wängnerud 2015, 61). The data also shows that the magnitude and shape of the segregation vary over time and over the different standing committees (Wängnerud 2009, 61).

Table 1 illustrates the vertical segregation of the Danish parliament, defined as speaker and vice-speakers of the parliament and chairs and vice-chairs of the standing committees. These positions have great impact on the policy as they prepare and govern the meetings. Throughout the 25 -year period considered here, the parliament had a male speaker, but in the summer of 2015 (after the parliamentary elections of 2015), a female speaker was elected. There is a vertical division of labour in terms of the chairs and vice-chairs of the standing committees, as male MPs are appointed more often as chairs and vice-chairs in the period concerned. It is worth pointing out that a declining vertical segregation happens relatively late in the Danish parliament compared to Sweden. 
Table 1. Total Number of Women and Men in Leadership Positions of the Danish Parliament 1989-2015. Selected Years

\begin{tabular}{|l|l|c|c|c|c|c|c|c|c|c|}
\hline Position & & $\mathbf{1 9 8 9}$ & $\mathbf{1 9 9 3}$ & $\mathbf{1 9 9 7}$ & $\mathbf{2 0 0 0}$ & $\mathbf{2 0 0 4}$ & $\mathbf{2 0 0 6}$ & $\mathbf{2 0 0 8}$ & $\mathbf{2 0 1 3}$ & $\mathbf{2 0 1 4}$ \\
\hline \multirow{2}{*}{$\begin{array}{l}\text { Speaker of the } \\
\text { House }\end{array}$} & $\mathrm{F}$ & 0 & 0 & 0 & 0 & 0 & 0 & 0 & 0 & 0 \\
\cline { 2 - 14 } & $\mathrm{M}$ & 1 & 1 & 1 & 1 & 1 & 1 & 1 & 1 & 1 \\
\hline $\begin{array}{l}\text { Vicespeaker of the } \\
\text { House }\end{array}$ & $\mathrm{F}$ & 2 & 2 & 2 & 1 & 0 & 0 & 0 & 2 & 2 \\
\cline { 2 - 13 } & $\mathrm{M}$ & 2 & 2 & 2 & 3 & 4 & 4 & 4 & 2 & 2 \\
\hline $\begin{array}{l}\text { Chair of the Par- } \\
\text { liamentary stand- } \\
\text { ing committees }\end{array}$ & $\mathrm{F}$ & 7 & 5 & 8 & 11 & 14 & 11 & 8 & 14 & 13 \\
\cline { 2 - 12 } & $\mathrm{M}$ & 20 & 25 & 19 & 16 & 16 & 18 & 21 & 15 & 17 \\
\hline $\begin{array}{l}\text { Vice-chair of the } \\
\begin{array}{l}\text { Parliamentary } \\
\text { standing commit- } \\
\text { tees }\end{array}\end{array}$ & $\mathrm{F}$ & 8 & 9 & 10 & 15 & 12 & 15 & 11 & 15 & 15 \\
\cline { 2 - 12 } & $\mathrm{M}$ & 19 & 21 & 17 & 12 & 18 & 14 & 18 & 15 & 15 \\
\hline
\end{tabular}

Sources: The Parliamentary yearbooks 1990-2008, the party secretariats and the minutes of the second plenum of the Parliamentary year 2008-2015. (The committee assignments are announced during the second plenum). $F=$ female; $M=$ male.

The gender composition of chairs of the standing committees in 1990-2015 is still gender segregated even if the general picture is "bumpy" (Wängnerud 2015, 63). As table 1 shows, the percentage of female chairs of the standing committees has risen throughout the period (particularly towards the end), whereas the number of female vice-chairs rose at an earlier stage.

Table 1 demonstrates that female parliamentarians started to become vice-chairs of the standing committees more frequently before they became chairs of these committees (the more prestigious position). Time is an important factor in this process, which confirms the time-lag hypothesis about segregation declining over time (Raaum 1995).

There has been some progress in terms of women being given leading positions in politics, but the broader analysis of gendered segregation of committee memberships reveals interesting patterns of change and stability. Table 2, 3 and 4 describe the gendered distribution of MPs in the standing committees for the period 1991-2015. 
Table 2. Danish Parliamentary Committees with more than $40 \%$ Female Representatives 1991-2015. Selected Years

\begin{tabular}{|c|c|c|c|c|c|c|c|c|c|c|c|}
\hline \multirow[b]{2}{*}{$\begin{array}{l}\text { Standing com- } \\
\text { mittees }\end{array}$} & & \multicolumn{2}{|c|}{$1991 / 1992$} & \multicolumn{2}{|c|}{$1997 / 1998$} & \multicolumn{2}{|c|}{$2003 / 2004$} & \multicolumn{2}{|c|}{$2009 / 2010$} & \multicolumn{2}{|c|}{$2014 / 2015$} \\
\hline & & $\begin{array}{l}\text { Num- } \\
\text { ber }\end{array}$ & $\begin{array}{l}\text { in } \\
\%\end{array}$ & $\begin{array}{l}\text { Num- } \\
\text { ber }\end{array}$ & $\begin{array}{l}\text { in } \\
\%\end{array}$ & $\begin{array}{l}\text { Num- } \\
\text { ber }\end{array}$ & $\begin{array}{l}\text { in } \\
\%\end{array}$ & $\begin{array}{l}\text { Num- } \\
\text { ber }\end{array}$ & $\begin{array}{l}\text { in } \\
\%\end{array}$ & $\begin{array}{l}\text { Num- } \\
\text { ber }\end{array}$ & $\begin{array}{l}\text { in } \\
\%\end{array}$ \\
\hline \multirow{2}{*}{ Elections } & $\mathrm{F}$ & 9 & 53 & 7 & 41 & 7 & 41 & 6 & 35 & 7 & 41 \\
\hline & $M$ & 8 & 47 & 10 & 59 & 10 & 59 & 11 & 65 & 10 & 59 \\
\hline \multirow{2}{*}{ Housing } & $\mathrm{F}$ & 7 & 41 & 10 & 59 & 9 & 53 & 4 & 24 & 14 & 48 \\
\hline & $M$ & 10 & 59 & 7 & 41 & 8 & 47 & 13 & 76 & 15 & 52 \\
\hline \multirow{2}{*}{ Citizenship } & $\mathrm{F}$ & 9 & 53 & 6 & 35 & 7 & 41 & 8 & 47 & 7 & 41 \\
\hline & $M$ & 8 & 47 & 11 & 65 & 10 & 59 & 9 & 53 & 10 & 59 \\
\hline \multirow{2}{*}{$\begin{array}{l}\text { Ecclesiastical } \\
\text { Affairs }\end{array}$} & $F$ & 10 & 59 & 9 & 53 & 9 & 53 & 8 & 47 & 11 & 38 \\
\hline & $M$ & 7 & 41 & 8 & 47 & 8 & 47 & 9 & 53 & 18 & 62 \\
\hline \multirow{2}{*}{ Culture } & $\mathrm{F}$ & 8 & 47 & 5 & 29 & 8 & 47 & 7 & 41 & 13 & 45 \\
\hline & $M$ & 9 & 53 & 12 & 71 & 9 & 53 & 10 & 59 & 16 & 55 \\
\hline \multirow{2}{*}{ Social } & $\mathrm{F}$ & 11 & 65 & 7 & 41 & 12 & 71 & 13 & 76 & 22 & 76 \\
\hline & $M$ & 6 & 35 & 10 & 59 & 5 & 29 & 4 & 24 & 7 & 24 \\
\hline \multirow{2}{*}{$\begin{array}{l}\text { Education and } \\
\text { Research }\end{array}$} & $\mathrm{F}$ & 10 & 59 & 7 & 41 & 11 & 65 & 11 & 69 & 14 & 48 \\
\hline & $M$ & 7 & 41 & 10 & 59 & 6 & 35 & 5 & 31 & 15 & 52 \\
\hline \multirow{2}{*}{ Justice } & $\mathrm{F}$ & 8 & 47 & 7 & 41 & 7 & 41 & 9 & 53 & 13 & 45 \\
\hline & $M$ & 9 & 53 & 10 & 59 & 10 & 59 & 8 & 47 & 16 & 55 \\
\hline \multirow{2}{*}{ Health } & $F$ & 11 & 65 & 10 & 59 & 10 & 59 & 12 & 71 & 16 & 55 \\
\hline & $M$ & 6 & 35 & 7 & 41 & 7 & 41 & 5 & 29 & 13 & 45 \\
\hline
\end{tabular}

Source: compare Table 1.

Table 2 illustrates the category of over-representation of women: the following standing committees have more than $40 \%$ female members throughout the analysed period: elections, housing, citizenship, ecclesiastical affairs, culture, social, education and research, justice, and health. The ecclesiastical affairs committee had an over-representation of women until 2014-2015.

Most of these committees - social, education and research, and health - have a marked over-representation of women throughout the period. Other committees especially culture and justice - move towards reflexive representation as the number of female members declines.

Table 3 shows the category of under-representation of women. Several standing committees have less than $30 \%$ female members in the analysed period, namely, foreign affairs, finance, defence, agriculture, fisheries and food, taxation, and transport. This category is complex when considered in a perspective of 25 years. The proportion of female MPs in these committees is generally lower than their proportion of ordinary representatives should imply. The growth in women's memberships mainly occurs 
late in the period. Men's specialization has declined along with the narrowing gender gaps (see also Bolzendahl 2014). Several committees - e.g. agriculture, fisheries, and food and taxation - have seen a decline in horizontal segregation.

The committee on foreign affairs is particularly interesting as it plays a special role in the Danish constitution. The committee on foreign affairs must be informed by the government before any foreign policy decision is made (Hansen 2010, 384).

The under-representation of women in the committees of defence, finance and transport illustrates Murray and Sénac's (2018) point that women's committee assignments do not always improve as their numbers increase. Despite the decline in horizontal segregation documented in tables 2 and 3, committee assignments may still reflect gendered perceptions of power, and my data reaffirm the notion that women deal with "soft" issues while men are associated with "hard" issues that convey power and mastery. Coding of policy issues as feminine and masculine illustrate their importance (Bolzendahl 2014, 852).

Table 3. Danish Parliamentary Committees with less than 30\% Female Representatives 1991-2015. Selected Years

\begin{tabular}{|c|c|c|c|c|c|c|c|c|c|c|c|}
\hline \multirow[b]{2}{*}{$\begin{array}{l}\text { Standing } \\
\text { committees }\end{array}$} & & \multicolumn{2}{|c|}{$1991 / 1992$} & \multicolumn{2}{|c|}{$1997 / 1998$} & \multicolumn{2}{|c|}{$2003 / 2004$} & \multicolumn{2}{|c|}{$2009 / 2010$} & \multicolumn{2}{|c|}{$2014 / 2015$} \\
\hline & & $\begin{array}{l}\text { Num- } \\
\text { ber }\end{array}$ & $\begin{array}{l}\text { in } \\
\%\end{array}$ & $\begin{array}{l}\text { Num- } \\
\text { ber }\end{array}$ & $\begin{array}{l}\text { in } \\
\%\end{array}$ & $\begin{array}{l}\text { Num- } \\
\text { ber }\end{array}$ & $\begin{array}{l}\text { in } \\
\%\end{array}$ & $\begin{array}{l}\text { Num- } \\
\text { ber }\end{array}$ & $\begin{array}{l}\text { in } \\
\%\end{array}$ & $\begin{array}{l}\text { Num- } \\
\text { ber }\end{array}$ & $\begin{array}{l}\text { in } \\
\%\end{array}$ \\
\hline \multirow{2}{*}{$\begin{array}{l}\text { Foreign } \\
\text { Affairs }\end{array}$} & $F$ & 2 & 12 & 3 & 18 & 4 & 24 & 4 & 24 & 7 & 41 \\
\hline & $M$ & 15 & 88 & 14 & 82 & 13 & 76 & 13 & 76 & 10 & 59 \\
\hline \multirow{2}{*}{ Finance } & $\mathrm{F}$ & 5 & 29 & 4 & 24 & 4 & 24 & 3 & 18 & 2 & 12 \\
\hline & $M$ & 12 & 71 & 13 & 76 & 13 & 76 & 14 & 82 & 15 & 88 \\
\hline \multirow{2}{*}{ Defence } & $F$ & 3 & 18 & 3 & 18 & 0 & 0 & 4 & 24 & 7 & 24 \\
\hline & $M$ & 14 & 82 & 14 & 82 & 17 & 100 & 13 & 76 & 22 & 76 \\
\hline \multirow{2}{*}{$\begin{array}{l}\text { Agriculture, } \\
\text { Fisheries and } \\
\text { Food }\end{array}$} & $F$ & 4 & 24 & 5 & 29 & 4 & 24 & 5 & 29 & 12 & 41 \\
\hline & M & 13 & 76 & 12 & 71 & 13 & 76 & 12 & 71 & 17 & 59 \\
\hline \multirow{2}{*}{ Taxation } & $\mathrm{F}$ & 5 & 29 & 7 & 41 & 5 & 29 & 2 & 12 & 9 & 31 \\
\hline & $M$ & 12 & 71 & 10 & 59 & 12 & 71 & 15 & 88 & 20 & 69 \\
\hline \multirow{2}{*}{ Transport } & $F$ & 3 & 18 & 3 & 18 & 2 & 12 & 3 & 18 & 7 & 24 \\
\hline & $M$ & 14 & 82 & 14 & 82 & 15 & 88 & 14 & 82 & 22 & 76 \\
\hline
\end{tabular}

Source: compare Table 1.

To explore changes over time further, it is interesting to look at the category of committees with reflexive representation (30-40\% women). Table 4 documents that the committees for political-economic affairs, environment, climate and energy, labour market, industry, local government, European affairs and foreign policy (not the same as the foreign affairs committee) have a reflexive representation of $30-40 \%$ women. This category is particularly interesting as it points towards a decline in 
horizontal segregation. Almost all of these committees have seen a relatively high representation of women since the 1990s. They move towards a type of convergence but to a lesser degree than in Sweden (Wängnerud 2015).

Table 4. Danish Parliamentary Committees with 30- 40\% Female Representatives 1991-2015. Selected Years

\begin{tabular}{|c|c|c|c|c|c|c|c|c|c|c|c|}
\hline & & \multicolumn{2}{|c|}{$1991 / 1992$} & \multicolumn{2}{|c|}{$1997 / 1998$} & \multicolumn{2}{|c|}{$2003 / 2004$} & \multicolumn{2}{|c|}{$2009 / 2010$} & \multicolumn{2}{|c|}{$2014 / 2015$} \\
\hline $\begin{array}{l}\text { Standing } \\
\text { committees }\end{array}$ & & $\begin{array}{l}\text { Num- } \\
\text { ber }\end{array}$ & $\begin{array}{l}\text { in } \\
\%\end{array}$ & $\begin{array}{l}\text { Num- } \\
\text { ber }\end{array}$ & $\begin{array}{l}\text { in } \\
\%\end{array}$ & $\begin{array}{l}\text { Num- } \\
\text { ber }\end{array}$ & $\begin{array}{l}\text { in } \\
\%\end{array}$ & $\begin{array}{l}\text { Num- } \\
\text { ber }\end{array}$ & $\begin{array}{l}\text { in } \\
\%\end{array}$ & $\begin{array}{l}\text { Num- } \\
\text { ber }\end{array}$ & $\begin{array}{l}\text { in } \\
\%\end{array}$ \\
\hline \multirow{2}{*}{$\begin{array}{l}\text { Political- } \\
\text { Economical }\end{array}$} & $\mathrm{F}$ & 3 & 18 & 6 & 35 & 6 & 35 & 6 & 35 & - & - \\
\hline & $M$ & 14 & 82 & 11 & 65 & 11 & 65 & 11 & 65 & - & - \\
\hline \multirow{2}{*}{ Environment } & $\mathrm{F}$ & 5 & 29 & 9 & 53 & 5 & 29 & 6 & 35 & 10 & 34 \\
\hline & $M$ & 12 & 71 & 8 & 47 & 12 & 71 & 11 & 65 & 19 & 66 \\
\hline \multirow{2}{*}{$\begin{array}{l}\text { Climate and } \\
\text { Energy }\end{array}$} & $\mathrm{F}$ & 6 & 35 & 6 & 35 & 5 & 29 & 6 & 35 & 8 & 28 \\
\hline & $M$ & 11 & 65 & 11 & 65 & 12 & 71 & 11 & 65 & 21 & 72 \\
\hline \multirow{2}{*}{$\begin{array}{l}\text { Labour } \\
\text { Market }\end{array}$} & $\mathrm{F}$ & 6 & 35 & 7 & 41 & 5 & 29 & 7 & 41 & 8 & 28 \\
\hline & M & 11 & 65 & 10 & 59 & 12 & 71 & 10 & 59 & 21 & 72 \\
\hline \multirow{2}{*}{ Industry } & $\mathrm{F}$ & 6 & 35 & 7 & 41 & 6 & 35 & 3 & 18 & 10 & 34 \\
\hline & $M$ & 11 & 65 & 10 & 59 & 11 & 65 & 14 & 82 & 19 & 66 \\
\hline \multirow{2}{*}{$\begin{array}{l}\text { Local } \\
\text { Government }\end{array}$} & $\mathrm{F}$ & 7 & 41 & 5 & 29 & 7 & 41 & 4 & 24 & 9 & 31 \\
\hline & $M$ & 10 & 59 & 12 & 71 & 10 & 59 & 13 & 76 & 20 & 69 \\
\hline \multirow{2}{*}{$\begin{array}{l}\text { European } \\
\text { Affairs }\end{array}$} & $\mathrm{F}$ & 3 & 18 & 6 & 35 & 9 & 53 & 8 & 47 & 8 & 28 \\
\hline & $M$ & 14 & 82 & 11 & 65 & 8 & 47 & 9 & 53 & 21 & 72 \\
\hline \multirow{2}{*}{ Foreign Policy } & $\mathrm{F}$ & 6 & 35 & 7 & 41 & 6 & 35 & 7 & 41 & 9 & 31 \\
\hline & $M$ & 11 & 65 & 10 & 59 & 11 & 65 & 10 & 59 & 20 & 69 \\
\hline
\end{tabular}

Source: compare Table 1.

\section{Interpreting the Findings and Future Research}

My data has documented vertical and horizontal segregation in the Danish parliament as well as a decline in segregation over time. The Danish case is complex. The longitudinal analysis shows that significant changes have occurred in the course of 25 years, but also that these changes have happened late and that segregation still exists. I cannot give a precise reason for this segregation based on my data. However, we can discuss various explanations based on previous research. In the following, I present three possible explanations for the gendered segregation in Danish committees.

The first explanation is time, and there is some data confirming the time-lag hypothesis that vertical and horizontal segregation declines over time (Raaum 1995). For a long time, access to leading positions in the parliament and chairs of standing 
committees was unequal (table 1; see also Bolzendahl 2014, 852). The vertical segregation of leadership has declined. The increase in the number of female chairs of standing committees represents an important decline in segregation. However, although MPs perceive the committees as powerful, they seemingly perceive the committee chairs as less powerful (Jensen 2004). This point needs further research. As far as the horizontal distribution of membership goes, there is also a limit to the explanatory power of the time-lag hypothesis. My data partly confirms a pattern of horizontal segregation that is almost similar to the pattern shown in Refsgaard's Danish study (1990). When we look at the period 1972-1988 (ibid.) and the data analysed here (1990-2015), it becomes clear that under- and over-representation of women are re-produced over time in certain committees. One major finding here is that the committees on defence, finance and agriculture, fisheries and food and to some extent foreign affairs are persistently characterised by an under-representation of women, whereas the committees on ecclesiastical affairs, culture, social affairs and education and research are persistently characterised by an over-representation of women according to the classification applied above.

The second explanation is inspired by Bolzendahl's thinking about legislative committee systems as gendered organizations $(2014,869)$. In light of the Danish history of women's rights and the gender equality culture (Inglehart/Norris/Welzel 2002), one would expect a specific parliamentary setting and gender dynamics. The empirical data leaves a mixed picture. However, there are certain indicators of new gender dynamics. If we base our discussion of prestige and power of the standing committees on ministerial rankings, which Hansen does (2010), then the picture is thoughtprovoking. Of the ten highest-ranking standing committees according to the Danish ministerial order, three can be categorized as underrepresented of women, two as an over-representation of women and five are in the category reflexive representation. Towards the end of the analysed period, the gendered patterns in the committees with the historically greatest under-representation of women $(<30 \%)-$ and an overrepresentation of men - are changing. The fact that some of these particular committees move towards reflexive representation indicates that a new situation might be occurring in a Danish context.

The third explanation is rooted in gendered perceptions of power (Bolzendahl 2014, 862-864) or gender stereotyping (Murray/Sénac 2018). Perception of power and gender associate or frame women with "soft" issues of care, the private sphere, people and frame male MPs with "hard" issues. These perceptions and stereotypes are transferred into political acts of assignment (ibid.).

In a historical analysis of Danish parliamentary debates, Kofoed (2015) argues that the political resistance to women's enfranchisement was linked to a conception of "female competences" as belonging to a different sphere than the political and to a fear of the social expansion of the electorate that would follow if women were given the right to vote. Later, this resistance changed towards a more positive approach to bringing women's special social skills and competences into parliament and poli- 
tics more generally. One can hypothesise that the historical construction of gender, politics and competences is embedded in the political institutions as the feminist institutional approach predicts.

\section{Conclusion}

The article has identified gendered patterns as well as changes in standing committees in the Danish parliament both vertically and horizontally. Even if the distribution of membership over a 25-year period does not give us a clear-cut indication of decline or reproduction of segregation, several points are provided.

First that we need to hold on to the notion of gendered segregation as a way of understanding the Danish parliament and most probably most parliaments. Even if some Danish parliamentary committees are moving towards some form of convergence (Bolzendahl 2014), there are still several parliamentary committees in the category of over- and under-representation of women. Second, the time-lag hypothesis is confirmed in the Danish case. My data reveals a decline in vertical and horizontal segregation. It is fair to say that these changes can be identified late in the period and that they lead to a broader question concerning these longitudinal changes. Are they, for instance, a general trend towards a less segregated distribution of seats (cf. Pansardi/Vercesi 2017)?

Based on the empirical evidence of a vertical and horizontal division of labour in various policy areas, one may ask what we can learn from the Danish case. It illustrates some of the theoretical debates within the field in a Nordic context with a long history of women's citizenship and enfranchisement. This study leaves ample room for more scholarly and theoretically informed analysis of gender and politics 100 years after enfranchisement to produce explanations for the gender segregation in committees (also Baekgaard/ Kjaer 2012; Murray/Sénac 2018). Future research needs to address the gendered organisation of the Danish parliament, political parties, individual parliamentarians' priorities, experiences, path dependency (Murray/ Sénac 2018) and the standing parliamentary committees.

If we return to Wängnerud's (2009) interpretation of gender differences in the parliamentary process, she describes two ways forward: a static and a dynamic. Static describes a gendered pattern that can be "interpreted as a division of labour between female and male politicians" (ibid., 66). The dynamic interpretation sees the emergence of "genuine change" (ibid). The Danish case seems to be situated between these two perspectives. It is also situated between a model of the Swedish egalitarian-trending gendered organisation and a German polarized gendered organisation (Bolzendahl, 2014). Time will reveal interesting new Danish data.

\section{Notes}

1 The author thanks the two anonymous reviewers and the editors for important feedback.

2 The initial study was part of a project about gender and power in the Nordic countries 20092011 (Niskanen/Nyberg 2009). The original study of the Danish case covered the period 1991- 
2004; the present study covers the period 1990-2015. A short presentation of some of the data is also available in Fiig/Verner (2016).

3 Hallberg's (2003) study of the Norwegian committee structure in 1945-2001 classified parliamentary committees with less than 30\% female MPs as male-dominated, committees with $31-40 \%$ as gender-balanced, and committees with more than $41 \%$ female MPs as committees with a high representation of women.

4 I only selected committees that existed throughout the entire period. Several committees were renamed. The most recent name is used.

5 In an earlier article in Danish, we applied a slightly different categorisation of the data (Fiig/ Verner 2016).

6 In comparison, Refsgaard's study (1990) of the Danish parliamentary committees (1965-1988) looks at the numerical representation of women in parliament in relation to the average representation of women in the parliamentary committees for every year.

7 I want to thank Drude Dahlerup for this term (personal communication).

\section{References}

Baekgaard, Martin/Kjaer, Ulrik, 2012: The Gendered Division of Labor in Assignments to Political Committees: Discrimination or Self-selection in Danish Local Politics. In: Politics \& Gender. 8 (4), 465-482.

Bergqvist, Christina/Borchorst, Anette/Christensen, Ann-Dorte/Ramsted-Silén, Viveca/Raaum, Nina C./Styrkársdóttir, Audur (Eds.), 1999: Equal Democracies? Gender and Politics in the Nordic Countries. Oslo.

Bolzendahl, Catherine, 2014: Opportunities and Expectations. The Gendered Organization of Legislative Committees in Germany, Sweden, and the United States. In: Gender \& Society. 28 (6), 847-876.

Carroll, Susan, 2008: Committee Assignments: Discrimination or Choice? In: Reingold, Beth (Ed.): Legislative Women: Getting Elected. Getting Ahead. Colorado, 135-156.

Celis, Karen/Lovenduski, Joni, 2018: Power Struggles: Gender Equality in Political Representation. In: European Journal of Politics and Gender. 1 (1-2), 149-166.

Christiansen, Peter/Møller, Birgit/Togeby, Lise, 2002: Den danske elite. Aarhus.

Dahlerup, Drude, 1988: From a Small to a Large Minority: Women in Scandinavian Politics. In: Scandinavian Political Studies. 11 (4), 275-298.

Dahlerup, Drude, 2013: Denmark: High Representation of Women without Gender Quotas. In: Dahlerup, Drude/Leyenaar, Monique (Eds.): Breaking Male Dominance in Old Democracies. Oxford, Chapter 7.

Dahlerup, Drude, 2018: Gender Equality as a Closed Case: A Survey among Members of the 2015 Danish Parliament. In: Scandinavian Political Studies. 41 (2), 188-209.

Dahlerup, Drude/Leyenaar, Monique, 2013: Introduction. In: Dahlerup, Drude/Leyenaar, Monique (Eds.): Breaking Male Dominance in Old Democracies. Oxford, Chapter 1.

Danish Parliament: https://www.thedanishparliament.dk/ (10.9. 2018).

Fiig, Christina, 2009: Women in Danish Politics: Challenges to the Notion of Gender Equality. In: Gelb, Joyce/Palley, Marian Lief (Eds.): Women and Politics Around the World: A Comparative History and Survey. Santa Barbara, 311-328.

Fiig, Christina/Verner, Mette, 2016: Lige for lige? Kønssegregering i Folketingsudvalg og i ledelsen af det private erhvervsliv. In: Politik. 19 (4), 89-112.

Frisch, Scott/Kelly, Sean, 2003: A Place at the Table. In: Women \& Politics. 25 (3), 1-26. 
Hallberg, Nina C., 2003: Kvinner i norsk topp-politikk 1945-2002. En studie av kjønnsspesifikke rekrutteringsmønstre i Storting og Regjering. Universitetet i Bergen.

Hansen, Martin Ejnar, 2010: Committee Assignment Politics in the Danish Folketing. In: Scandinavian Political Studies. 33 (4), 381-401.

Heath, Roseanna/Schwindt-Bayer, Leslie A./Taylor-Robinson, Michelle M., 2005: Women on the Sidelines: Women's Representation on Committees in Latin American Legislatures. In: American Journal of Political Science. 49 (2), 420-436.

Hernes, Helga M., 1987: Welfare State and Woman Power: Essays in State Feminism. Vojens.

Holli, Anne Maria/Harder, Mette Marie, 2016: Towards a Dual Approach: Comparing the Effects of Parliamentary Committees on Gender Equality in Denmark and Finland. In: Parliamentary Affairs. 69 (4), 794-811.

Inglehart, Ronald/Norris, Pippa/Welzel, Christian, 2002: Gender Equality and Democracy. In: Comparative Sociology. 1 (3-4), 321-345.

Jensen, Henrik, 2002: Partigrupperne i Folketinget. Copenhagen.

Jensen, Torben K., 2004: De folkevalgte. En analyse af Folketingsmedlemmernes sociale baggrund og repræsentationsadfærd. Aarhus.

Karvonen, Lauri/Selle, Per (Eds.), 1995: Closing the Gap. Women in Nordic Politics. Dartmouth.

Kofoed, Nina J., 2015: Vejen til lige og almindelig stemmeret. In: Dahlerup, Drude/Borchorst, Anette (Eds.): Før og efter stemmeretten - køn, demokrati og velfærd. Frydenlund, 61-82.

Mattson, Ingvar/Strøm, Kaare, 1995: Parliamentary Committees. In: Döring, Herbert (Ed.): Parliaments and Majority Rule in Western Europe. New York, 249-307.

Moustgaard, Ulrikke, 2004: Håndtasken, heksen og de blåøjede blondiner. Danske kvindelige politikere ifølge pressen og dem selv. Frederiksberg.

Murray, Rainbow/Sénac, Réjane, 2018: Explaining Gender Gaps in Legislative Committees. In: Journal of Women, Politics and Policy. 39 (3), 310-335.

Niskanen, Kirsti/Nyberg, Anita, 2009: Kön og magt i Norden. Copenhagen.

Norris, Pippa/Lovenduski, Joni, 1995: Political Recruitment: Gender, Race and Class in the British Parliament. Cambridge.

Pansardi, Pamela/Vercesi, Michelangelo, 2017: Party-Gate-Keeping and Women's Appointment to Parliamentary Committees: Evidence from the Italian Case. In: Parliamentary Affairs. 70 (1), $62-83$.

Raaum, Nina C., 1995: Women in Local Democracy. In: Karvonen, Lauri/Selle, Per (Eds.): Closing the Gap. Women in Nordic Politics. Dartmouth, 25-58.

Refsgaard, Elisabeth, 1990: Tæt ved toppen. Kvinders placering i Folketingets arbejds- og magtdeling 1965-1990. In Dahlerup, Dahlerup/Hvidt, K. (Eds.): Kvinder på Tinge. Copenhagen, 106-139.

Skjeie, Hege, 1992: Den politiske betydningen av kjønn. Institute for Social Research. Report 92: 11. Oslo.

Skjeie, Heige/Teigen, Mari, 2003: Menn imellom. Mannsdominans og likestillingspolitikk. Makt og Demokratiutredningen. Oslo.

Thomas, Sue, 1994: How Women Legislate. Oxford.

Togeby, Lise, 1995: A Gender Gap that Vanished. In: Karvonen, Lauri/Selle, Per (Eds.): Closing the Gap. Women in Nordic Politics. Dartmouth.

Wängnerud, Lena, 2009: Women in Parliaments: Descriptive and Substantive Representation. In: Annual Review of Political Science. 12, 51-69.

Wängnerud, Lena, 2015: The Principles of Gender-Sensitive Parliaments. Oxford. 


\section{FORUM}

\section{Femi(ni)zide in Deutschland - ein Perspektivwechsel}

\section{ALEX WISCHNEWSKI}

Frauenmorde sind kein neues Phänomen, sondern so alt wie das Patriarchat selbst (Radford/Russell 1992). Und doch erhielt es in jüngster Zeit international neue Aufmerksamkeit. Auslöser dafür war der Mord an der argentinischen Schülerin Chiara Paéz im Mai 2015. Ihr Freund erschlug die 14-Jährige, weil sie keine Abtreibung vornehmen lassen wollte, und vergrub sie mit Hilfe seiner Familie im Garten. Daraufhin bildete sich ,ni una menos“ (,Nicht eine weniger“), ein Kollektiv von Journalistinnen, Künstlerinnen und Aktivistinnen, das am 3. Juni 2015 hunderttausende Menschen gegen Frauenmorde mobilisierte, sowohl in den sozialen Medien als auch auf der Straße. Seither hat sich die Bewegung nicht nur verstetigt, sondern wurde auch in einer Vielzahl anderer Länder aufgegriffen, insbesondere in Lateinamerika - darunter in Chile, Peru oder Mexiko - aber auch in Spanien, Italien (,non una di meno") oder Albanien. Auch wenn die Proteste 2015 als ein qualitativer Sprung in der Thematisierung von Frauenmorden aufgefasst werden können, stützt sich die Bewegung auf eine bereits Jahrzehnte andauernde Debatte in den Sozialwissenschaften und feministischen Organisationen um das Konzept des Femizids/Feminizids, also der Tötung von Frauen, weil sie Frauen sind.

In Deutschland steht eine solche Diskussion allerdings noch weitestgehend aus. Die im März 2017 gegründete Plattform „Keine Mehr“ möchte deshalb genau hier ansetzen. Anschließend an diese Initiative will der folgende Beitrag eine Auseinandersetzung darüber anstoßen, was in unterschiedlichen Bereichen sichtbar wird, was sich verändert und verändern müsste, wenn das Konzept des Femizids/Feminizids im deutschen Kontext verwendet wird. Dazu zählen insbesondere die Bereiche Statistikerhebung und Forschung, mediale und gesellschaftliche Diskurse sowie Gesetzgebung und Rechtsprechung. Es kann und soll sich an dieser Stelle jedoch nur um erste Anregungen für weitere Forschung und Debatten auf wissenschaftlicher, gesellschaftspolitischer und juristischer Ebene handeln.

\section{Femizid und Feminizid - eine Begriffsfindung}

Eingeführt hatte den Begriff femicide (Femizid) die Soziologin Diane Russell 1976, als sie ihn vor dem Internationalen Tribunal zu Gewalt gegen Frauen in Brüssel im Kontext von Tötungen von Frauen durch Männer verwendete, ohne ihn jedoch näher zu definieren (Russell 2011a). ${ }^{1}$ Das Verständnis eines ,,mysogynous killing of women by men“ führte sie erst 1992 zusammen mit Jill Radford weiter aus (Rad- 
ford/Russell 1992, 3). Obwohl sie sich in ihrer Anthologie auf den britischen und US-amerikanischen Kontext fokussieren, wurde die Debatte vor allem in Lateinamerika aufgegriffen und weitergeführt. In Mexiko war es die Anthropologin Marcela Lagarde y de los Ríos (2006), die den Begriff in den wissenschaftlichen Diskurs einbrachte. Sie übersetzte ihn jedoch auf Spanisch mit feminicidio (Feminizid). Die sprachlich korrekte Übertragung als femicidio (Femizid) bezeichne, so Lagarde y de los Ríos, lediglich die weibliche Form der allgemeinen Tötung (homicidio) und daher jeglichen Mord an Frauen. Dies stehe dem politischen Gehalt des Konzepts jedoch entgegen, das nicht nur Tötungen nach dem Geschlecht des Opfers differenzieren, sondern gerade jene Tötungen herausheben möchte, die geschlechtsbasiert sind. Der Begriff Feminizid soll klarstellen, dass zwar alle Feminizide Tötungen von Frauen, aber nicht alle Tötungen von Frauen Feminizide sind, denn nicht alle sind durch hierarchische Geschlechterverhältnisse motiviert. Zudem ist für Lagarde y de los Ríos die weitläufige Straflosigkeit in diesen Fällen ein Definitionsmerkmal für Feminizide. Der Staat komme durch die mangelnde Strafverfolgung seiner Verantwortung nicht nach, für das Leben und die Sicherheit von Frauen zu sorgen. Russell wiederum kritisiert diese Erweiterung, da auch Feminizide, die strafrechtlich verfolgt werden, weiterhin Feminizide seien und nicht überall, wo sie stattfinden, Straflosigkeit vorherrsche (Russell 2011a).

Die Wahl zwischen den Begriffen Femizid und Feminizid hat aus diesen Gründen immer wieder zu hitzigen Debatten geführt. Viele Theoretiker_innen verwenden jedoch inzwischen beide Begriffe synonym, um für einen Zusammenschluss der Kräfte statt einer spaltenden Begriffsdiskussion zu plädieren, zumal in der Beschreibung des Phänomens ausreichend Einigung existiert. Dem möchte ich mich im Folgenden anschließen, wobei sich bei der Verwendung im Deutschen auch Fragen auftun. Anders als das englische homicide oder das spanische homicidio bieten die deutschen Begriffe Mord und Tötung keine Analogie. So ist anzunehmen, dass häufig eine Assoziation mit Genozid ausgelöst wird, was ein Verständnis des Konzepts behindern kann. Für den Gebrauch der Begriffe Femizid und Feminizid spricht hingegen die Anbindung an die internationalen Debatten und in diesem Sinne auch die Markierung eines globalen Phänomens. Letztlich kann erst eine Auseinandersetzung mit dem Thema im deutschen Kontext zeigen, ob der Begriff und sein politischer Gehalt Anschluss finden werden.

\section{Absicherung männlicher Herrschaft}

Gemein ist den verschiedenen Ansätzen, Feminizide als extremen Ausdruck hierarchischer Geschlechterverhältnisse und männlichen Dominanzbestrebens zu fassen. Für Rita Segato beruht die männliche Vormachtstellung auf der Ausübung von Herrschaft in unterschiedlichen, miteinander verflochtenen Formen, sei es ,sexuell, intellektuell, ökonomisch, politisch oder kriegerisch“ (Segato 2010, 5, Übers. AW). Die Herrschaft komme insbesondere dann zum Tragen, wenn diese männlich-he- 
gemoniale Position angegriffen wird, und verdränge auch die emotionalen Aspekte in den Beziehungen zwischen Männern und Frauen. Der Rückgriff auf körperliche Gewalt durch den Mann ersetze jegliche Dimension der persönlichen Bindung zur Beziehungspartnerin durch den bloßen Willen zur Beherrschung (ebd.). Die Verteidigung einer überlegenen Stellung unterstreicht auch Russell, wenn sie bezugnehmend auf eine Studie von Jacquelyn Campbell und anderen (Campbell et al. 2003) die relative Zunahme von Femiziden in Partnerschaften zwischen 1976 und 1996 in den USA mit den Fortschritten feministischer Bewegungen in dieser Zeit in Beziehung setzt. Die Gleichzeitigkeit beider Entwicklungen „legt nahe, dass die wachsende Unabhängigkeit von Frauen dazu geführt hat, dass einige Männer mit tödlicher Gewalt reagieren. Diese Männer, die sich bedroht oder herausgefordert fühlen, scheinen sich berechtigt zu fühlen, jede notwendige Gewalt anzuwenden, um die Herrschaft über die zu behalten, die sie für ihre Untergebenen halten" (Russell 2011b, o.S., Übers. AW).

Unterstützt wird diese Auffassung durch Analysen zu Gewalt und Tötungen in Partnerschaften, die weltweit am häufigsten auftretende Form von Femiziden (Campbell et al. 2007, zit.n. World Health Organization 2012). Dagmar Oberlies analysierte bereits 1995 anhand von gerichtlichen Rekonstruktionen die Kontexte, in denen unter anderem Tötungen von gewalttätigen Männern an ,ihren' Frauen stattfinden. Darin zeichnet sie ein „Bild der Beherrschung, der Herrschaft über Frauen (...). Gewalt, die Männer über Frauen ausüben, ist in den geschilderten Beziehungen das Mittel, um Frauen ihren Willen zu nehmen. Die Tötung ist das letzte dieser Mittel“" (Oberlies 1995, 79f.). Besonders deutlich werde das bei sogenannten Trennungstötungen. „Der in dem Entschluss zur Trennung zum Ausdruck kommende eigene Willen der Frau soll um jeden Preis wieder gebrochen werden“ (ebd., 82). Tatsächlich untermauern auch repräsentative Studien für Deutschland das ganz besondere Risiko von Frauen, in Trennungs- und Scheidungssituationen Opfer von Gewalt durch ihren Partner oder Ex-Partner zu werden (Schröttle/Müller 2004). Auch der berufliche Ein- oder Aufstieg von Frauen oder die Arbeitslosigkeit des Partners können mit Partnerschaftsgewalt einhergehen, häufiger sind es Schwangerschaft und Geburt (Schröttle/Müller 2004; World Health Organization 2012). Wie Oberlies festhält, stehen Tötungen oft am Ende wiederholter Gewalthandlungen, weshalb sie - ähnlich wie Lagarde - Interventionen von außen vermisst. „Eine Gesellschaft, die nicht konsequent gegen Gewalt gegen Frauen vorgeht, nimmt deren Tötung billigend in Kauf" (Oberlies 1995, 79).

Als Ausdruck eines gesellschaftlichen Verhältnisses ist Gewalt gegen Frauen zudem in dessen Dynamik zu untersuchen. Sylvia Walby, Jude Towers und Brian Francis kamen etwa in einer geschlechtersensiblen Auswertung der allgemeinen Straftatenstatistik 1994-2014 für England und Wales zu dem Ergebnis, dass viele Formen von Gewaltverbrechen gegen Frauen seit der Wirtschaftskrise 2008/09 zugenommen haben. Das betreffe ganz besonders familiäre Beziehungen und stehe im klaren Kontrast zur Abnahme von Gewaltverbrechen gegen Männer im selben Zeitraum. 
Für die Autor_innen scheint dies ,im Einklang mit einer Erklärung, die sich auf die verringerte wirtschaftliche Unabhängigkeit von Frauen und die Auswirkungen der Kürzungen von Dienstleistungen, von denen Frauen überproportional abhängig sind, konzentriert“" (Walby/Towers/Francis 2016, 1225, Übers. AW), zu stehen. Sie schränken jedoch ein, dass hier weitere Untersuchungen notwendig seien. Es liegt auf der Hand, dass Frauen, denen es an finanziellen Ressourcen fehlt, sich schwerer aus einer gewalttätigen Beziehung lösen können und so einem höheren Risiko ausgesetzt sind. Das gilt insbesondere dann, wenn Unterstützungsmöglichkeiten wie Frauenhäuser oder Beratungsangebote den Haushaltskürzungen in der Krise zum Opfer fallen. Vor dem Hintergrund der wissenschaftlichen Debatten um Feminizide kann das Ergebnis dieser Untersuchung indes auch anders gedeutet werden. Denn wenn Gewalt gegen Frauen durch Männer die Funktion hat, die Geschlechterhierarchie aufrechtzuerhalten oder wiederaufzurichten, stellt sich vielmehr die Frage, ob Männer, die durch die Wirtschaftskrise Prekarisierung erfahren haben, ihre schwindende Vormachtstellung durch Gewalt gegen Frauen kompensieren wollen.

\section{Fehlende Analysen in Deutschland}

Für Deutschland fehlen tiefergehende Analysen zur Gewalt gegen Frauen allgemein und Tötungen im Besonderen im Zeitverlauf, was es unmöglich macht, die Zusammenhänge mit gesellschaftlichen Entwicklungen aufzudecken. Um ein ungefähres Bild von Feminiziden zu zeichnen, können jedoch hilfsweise Zahlen des Bundeskriminalamtes zu Gewalt durch aktuelle oder ehemalige Partner herangezogen werden, die seit 2011 jährlich erhoben werden (Bundeskriminalamt 2018). Dieser Polizeilichen Kriminalstatistik (PKS) zufolge wurden im Jahr 2017147 Frauen von ihren (Ex-)Partnern getötet. ${ }^{2}$ Bei weiteren 224 war die Tötung gescheitert, vermutlich häufig durch reines Glück. In Deutschland fand 2017 also täglich eine versuchte oder vollendete Tötung einer Frau durch ihren (Ex-)Partner statt. Nach Angaben von Beratungsstellen besteht allerdings eine hohe Dunkelziffer an versuchten Tötungen, da sie häufig nicht als solche erkannt und erst recht nicht angezeigt werden, so etwa bei Angriffen auf den Hals (Frauenhauskoordinierung et al. 2012, zit.n. Wir Frauen o.J.). Angesichts der Berichte über jene Länder, in denen bereits Bewegungen gegen Feminizide existieren, könnte man argumentieren, dass diese Zahlen sehr niedrig seien. Ländervergleiche sind jedoch aufgrund der unterschiedlichen Quellen und zugrunde gelegten Definitionen schwierig.

Da es sich auch beim Heranziehen der PKS um eine Hilfskonstruktion handelt, bleiben zudem viele Fragen offen: Auch wenn der Großteil von Femiziden innerhalb von Partnerschaften stattfindet, gilt dies nicht zwangsläufig. Waren also all diese Tötungen tatsächlich geschlechtsspezifisch? Was ist mit den 77 Frauen, die von Familienangehörigen umgebracht wurden? Was ist mit den 51 getöteten und 27 entkommenen Frauen, bei der die Beziehung zum Täter ungeklärt ist? Ganz generell, was geschah den rund $61 \%$ der weiblichen Opfer von Tötungsdelikten, die nicht 
eindeutig in einer Beziehung stattfanden? Und wo finden sich die Tötungen von Trans*Frauen? Die Zahlen des BKA sagen es nicht, denn sie sind nicht darauf ausgerichtet, die Frage nach Feminiziden zu beantworten. Die Sonderberichterstatterin der Vereinten Nationen zu Gewalt gegen Frauen, Dubravka Šimonović, fordert mit Blick auf mangelnde Daten die Gründung eines „Femicide-Watch“ in jedem Land, das Informationen zu Opfern, Tätern und ebenso dem Verlauf der Strafverfolgung sammeln und jährlich veröffentlichen soll (Šimonović 2015). Eine solche Art Forschungsinstitut wäre die notwendige Grundlage, um die theoretischen Überlegungen zu überprüfen und eventuell noch unerkannte Zusammenhänge im deutschen Kontext zu erschließen.

\section{Zwischen ,Eifersuchtsdrama“ und ,Ehrenmord“}

Ein Grund für die mangelnde Erfassung ist das fehlende gesellschaftliche und politische Bewusstsein für Feminizide. Ausschlaggebend ist hier auch die mediale Berichterstattung, die bei Tötungen durch Partner sehr häufig von „Eifersuchtsdrama“ oder „Familientragödie“" spricht. Begriffe, die das Bild von traurigen Schicksalsschlägen produzieren, ohne strukturelle Machtverhältnisse zu thematisieren, und die das geschehene Verbrechen gänzlich, entnennen'. Nur im Falle des Begriffs ,Ehrenmord' wird die Tötung selbst überhaupt sprachlich aufgegriffen.

Doch auch hier verstellt schon die Bezeichnung den Blick auf die Opfer. Schieben die Begriffe ,Familiendrama' oder ,Beziehungstat' das Problem ins Private, so fügt sich ,Ehrenmord“ in eine Erzählung ein, die sich auf die kulturelle Prägung des Täters beschränkt. „Ehrenmorde lösen auch deswegen so große Aufmerksamkeit aus, weil sie als Symbol der kulturellen Unterschiede zwischen der deutschen Mehrheitsgesellschaft und den Herkunftskulturen der Einwanderer dienen", konstatieren Dietrich Oberwittler und Julia Kasselt $(2011,2)$ in einer im Auftrag des Bundeskriminalamts angefertigten Studie zu ,Ehrenmorden' in Deutschland, in der sie sowohl Prozessakten als auch Medienberichterstattungen als Material heranziehen (ähnlich Folyanti/Lembke 2014). Es ist daher auch nicht verwunderlich, dass ,Ehrenmorde' immer wieder als Kronzeugen für Diskussionen über eine mangelnde Integration von Migranten insbesondere aus islamischen Ländern dienen müssen. Besondere Bedeutung hatte der Mord an Hatun Sürücü im Jahr 2005 in Berlin. Ihr Bruder hatte sie getötet, da er seine Wertevorstellungen durch den, westlichen und unabhängigen Lebensstil der 23-Jährigen verletzt sah. Infolge war eine ,explosionsartige Entwicklung der Medienaufmerksamkeit für das Thema Ehrenmorde" zu verzeichnen (Oberwittler/Kasselt 2011, 2). Nach Freisprüchen für zwei weitere Brüder, denen eine Beteiligung nicht nachgewiesen werden konnte, forderte der damalige sozialdemokratische Berliner Innensenator Ehrhart Körting die Familie zur Auswanderung auf (Tagesspiegel 13.4.2006) ${ }^{3}$, andere Politiker zogen nach. Vor dem Hintergrund dieser Debatten wurde 2005 schließlich das Zuwanderungsgesetz verschärft. 
Die BKA-Studie verneint nicht den kulturellen Einfluss oder die Bedeutung eines spezifischen Wertesystems bei ,Ehrenmorden“ im engeren Sinne, definiert als „die Tötung eines Mädchens oder einer jungen Frau durch ihre Blutsverwandten zur Wiederherstellung der kollektiven Familienehre“ (Oberwittler/Kasselt 2011, 165). Sie stellt jedoch heraus, dass die meisten Fälle, denen dieser Aspekt zugeschrieben wird, tatsächlich eine andere Motivlage aufweisen. „Häufiger als Ehrenmorde im engeren Sinn sind Grenzfälle zur Partnertötung, bei denen die Ehefrau oder Partnerin durch Unabhängigkeitsstreben, Trennung bzw. Trennungsabsicht oder (vermutete) Untreue den Anlass für die gewaltsame Reaktion des (Ex-)Partners gibt“" (ebd.). Diese Konstellation wiederum sei in allen Gesellschaften gleich und ließe sich ,grundsätzlich als extremer Ausdruck männlichen Dominanz- und Besitzdenkens gegenüber Frauen deuten" (ebd.).

Dass in Fällen eines nicht-deutschen Täters also weniger ein tatsächlicher Wunsch nach Verständnis und Aufklärung im Vordergrund zu stehen scheint, sondern vielmehr die rassistische Instrumentalisierung, zeigt sich erneut in den aktuellen Debatten. Als die ARD-Tagesschau den Mord an einem 15-jährigen Mädchen durch ihren afghanischen Exfreund in Kandel im Dezember 2017 als „Beziehungstat“ einordnete und aus diesem Grund zunächst nicht darüber berichtete (ARD-aktuell 28.12.2017), gab es einen großen Aufschrei. Im deutschen Kontext ist diese Beschreibung jedoch Standard. Das Konzept des Feminizids hat hier großes Potential, weil es weder verharmlost noch aussondert. Vielmehr sollen damit sowohl Morde im Namen einer vermeintlichen Ehre als auch sogenannte Beziehungstaten zu Fragen des öffentlichen Interesses erhoben werden. Was im Falle von ,Ehrenmorden“ meist als kultureller Hintergrund bezeichnet wird, fasst das Konzept des Femizids als gesellschaftliche Bedingungen, die jeweils genauer untersucht werden müssen.

\section{Rechtsprechung als Spiegel gesellschaftlicher Debatten}

Gesellschaftliche Debatten und Bewusstsein sind aber nicht nur mit Blick auf die politischen Schlussfolgerungen relevant, sondern ebenso für die Rechtsprechung. Der deutsche Mordparagraf ( $\$ 211$ StGB) beinhaltet das Merkmal der niederen Beweggründe, das eine Gesamtwürdigung aller äußeren und inneren für die Handlungsantriebe von Täter_innen maßgeblichen Faktoren erfordert, und damit eine normative Bewertung durch das Gericht. Bei Urteilen zur Tötung von Intimpartnerinnen scheint es einer Analyse der Rechtswissenschaftlerin Ulrike Lembke zufolge „fast beliebig, ob in vergleichbaren Konstellationen die Motive des Täters als Absprechen des Lebensrechtes, rücksichtsloser Eigennutz, Frust, Bestrafungswille, Rachsucht oder umgekehrt als Sorge um Kindeswohl, Affekt, Verzweiflung, Ausweglosigkeit, Trennungsschmerz bewertet werden" (Lembke 2009, 111). Im ersten Fall werden also niedere Beweggründe anerkannt, was Mord und damit zwingend lebenslange Haft bedeutet; im zweiten Fall jedoch nicht, weshalb es sich dann um Totschlag mit Freiheitsentzug von 5 bis 15 Jahren handelt. Das deutsche Strafgesetzbuch erkennt sogar einen minder 
schweren Fall des Totschlages an, wenn die Täter_innen „ohne eigene Schuld durch (...) schwere Beleidigung von dem getöteten Menschen zum Zorn gereizt“ ( $\$ 213$ StGB) worden sind. Auch hier obliegt es dem Gericht zu beurteilen, was als schwere Beleidigung gelten kann. Systematische Untersuchungen über die Anwendung fehlen. Im Gegensatz zur Rechtsprechung bei Tötungen in Partnerschaften hat die öffentliche Debatte um ,Ehrenmorde' dazu geführt, dass die objektive Verwerflichkeit in diesen Fällen nicht mehr angezweifelt wird, und gleichzeitig die subjektive Dimension kaum mehr Berücksichtigung findet. Lena Folyanti und Ulrike Lembke zufolge führe „die Fokussierung auf die fremde homogene Kultur in den ,Ehrenmord'-Fällen dazu, dass nicht mehr darauf eingegangen wird, ob die Täter individuell verzweifelt waren " (Folyanti/Lembke 2014, 312). Das hat zur Folge, dass sie, anders als Trennungstötungen, in der Regel das Mordmerkmal der niederen Beweggründe erfüllen. Von einem „IslamRabatt" (Bild.de 31.3.2014) kann also nicht die Rede sein. Die Rechtswissenschaftlerinnen kommen deshalb zu dem Schluss: „Die Rechtsprechung zu Trennungstötungen stellt den Rechtsstaat in Frage, die Rechtsprechung zu ,Ehrenmorden ' vernachlässigt das (individuelle) Schuldprinzip. Eine gute Balance finden beide nicht" (Folyanti/ Lembke 2014, 312). Hier fehlt es an weiteren juristischen Überlegungen, wie die Beurteilung der konkreten Tat und die Berücksichtigung der geschlechterhierarchischen Strukturen, wie es das Konzept des Femizids vorsieht, in Einklang gebracht werden können. Eine Forderung, einen eigenen Straftatbestand des Femizids einzuführen, wie er in vielen lateinamerikanischen Ländern inzwischen existiert, wäre angesichts mangelnder Vorschläge einer rechtsdogmatischen Einbettung verfrüht.

\section{Femi(ni)zide benennen! Als Konzentration feministischer Kritiken}

Ob nun auf wissenschaftlicher, gesellschaftspolitischer oder juristischer Ebene: Das Konzept Femi(ni)zid wirft viele Fragen an die Verhältnisse in Deutschland auf. Sind ,wir' vielleicht doch nicht so geschlechtergerecht wie vielerorts behauptet? Welche gesellschaftlichen Entwicklungen der letzten Jahre drücken sich in der Gewalt gegen Frauen aus? Welche Gruppen an Frauen sind möglicherweise besonders häufig betroffen, die aktuell noch nicht sichtbar sind? An welcher Stellschraube kann eine effektive Prävention ansetzen? Wie wirkungsvoll ist die Strafverfolgung in Deutschland? Doch um diesen Fragen nachgehen zu können, ist weit mehr Wissen notwendig als die bloße Zahl toter Frauen. Umfassendes Material ist erforderlich, anhand dessen etablierte Thesen zu Femi(ni)ziden überprüft und Analysen zu den spezifischen Ausprägungen in Deutschland überhaupt erst erstellt werden können. Erst das wiederum kann die Grundlage einer politischen Auseinandersetzung sein, die sich nicht von rassistischen Stimmungen leiten lässt, sondern an tatsächlicher Prävention von Gewalt gegen Frauen interessiert ist.

Für die Plattform „Keine Mehr“ und eine breitere feministische Bewegung eignet sich der Begriff Femi(ni)zid derweil schon jetzt, um verschiedene Kritiken patriarchaler Verhältnisse zu bündeln und um die notwendigen Forschungen und Debatten 
praktisch einzufordern. Das bedeutet jedoch nicht, dass nicht auch hier noch offene Fragen bestehen. Wie kann in der Thematisierung von Femi(ni)ziden einer Essentialisierung des Subjekts Frau vorgebeugt werden? Wie kann trotz des Fokus auf die Tötung von Frauen ein althergebrachter Opfer-Diskurs durchbrochen werden? Wie kann verhindert werden, dass auch die Begriffe Femizid und Feminizid kulturalisierend oder moralisch vereinnahmt werden? Auch an dieser Stelle werden sich die praktischen Antworten am deutschen Kontext orientieren müssen.

\section{Anmerkungen}

1 Eigenen Angaben zufolge griff sie den Titel einer geplanten Anthologie der US-amerikanischen Schriftstellerin Carol Orlock auf, die jedoch niemals veröffentlicht wurde (Russell 2011a).

2 Anders als beim Bundeskriminalamt in seinen Auswertungen der Polizeilichen Kriminalstatistiken (PKS) werden in diesem Text stets auch Körperverletzungen mit Todesfolge in die Zahl der Tötungen einberechnet.

3 „Wenn sie denn wirklich Ehre im Leib hätten, dann sollten sie die Konsequenz ziehen und die Bundesrepublik Deutschland verlassen", so Körting (Tagesspiegel 13.4.2006).

\section{Literatur}

ARD-aktuell, 2017: Kandel - wie die tagesschau damit umgeht. Internet: http://blog.tagesschau. de/2017/12/28/kandel-wie-die-tagesschau-damit-umgeht/ (1.7.2018).

Bild.de, 2014: Geben unsere Gerichte Islam-Rabatt? Internet: https:/www.bild.de/news/inland/ gerichtliche-entscheidung/tote-jolin-geben-unsere-gerichte-islam-rabatt-35291480.bild.html (6.7.2018).

Bundeskriminalamt, 2018: Polizeiliche Kriminalstatistik 2017. Übersicht Opfertabellen. Internet: https://www.bka.de/DE/AktuelleInformationen/StatistikenLagebilder/PolizeilicheKriminalstatistik/PKS2017/Standardtabellen/standardtabellenOpfer.html;jsessionid=100896F7240C94D2134 86D3D8136F4A5.live0602?nn=96600 (6.7.2018).

Campbell, Jacquelyn C./Glass, Nancy/Sharps, Phyllis W./Laughon, Kathryn/Bloom, Tina, 2007: Intimate Partner Homicide. Review and Implications of Research and Policy. In: Trauma, Violence, \& Abuse. 8 (3), 246-269.

Campbell, Jacquelyn C./Webster, Daniel/Koziol-McLain, Jane/Block, Carolyn/Campbell, Doris/ Curry, Mary Ann/Gary, Faye/Glass, Nancy/McFarlane, Judith/Sachs, Carolyn/Sharps, Phyllis/Ulrich, Yvonne/Wilt, Susan A./Manganello, Jennifer/Xu, Xiao/Schollenberger, Janet/Frye, Victoria/ Laughon, Kathryn, 2003: Risk-factors for Femicide in Abusive Relationships. Results from a Multisite Case Control Study. In: American Journal of Public Health. 93 (7), 1089-1097.

Folyanti, Lena/Lembke, Ulrike, 2014: Die Konstruktion des Anderen in der „Ehrenmord“-Rechtsprechung. In: Kritische Justiz. 47 (3), 298-315.

Lagarde y de los Ríos, Marcela, 2006: Presentación a la edición en español. In: Russell, Diane (Hg.): Feminicidio. Una perspectiva global. Mexiko-Stadt, 11-14.

Lembke, Ulrike, 2009: Das Recht des Stärkeren. Zur schwierigen dogmatischen Beziehung von Heimtückemord, Trennungstötung und Gewaltschutzgesetz. In: Neue Kriminalpolitik. 21 (3), 109-113.

Oberlies, Dagmar, 1995: Tötungsdelikte zwischen Männern und Frauen. Eine Untersuchung geschlechtsspezifischer Unterschiede aus dem Blickwinkel gerichtlicher Rekonstruktionen. Pfaffenweiler. 
Oberwittler, Dietrich/Kasselt, Julia, 2011: Ehrenmorde in Deutschland 1996-2005. Eine Untersuchung auf der Basis von Prozessakten. Im Auftrag des Bundeskriminalamtes. Köln.

Radford, Jill/Russell, Diane (Hg.), 1992: Femicide. The Politics of Woman Killing. New York.

Russell, Diane, 2011a: The Origin and Importance of the Term Femicide. Internet: http://www. dianarussell.com/origin_of_femicide.html (30.6.2018).

Russell, Diane, 2011b: Femicide. The Power of a Name. Internet: http://www.dianarussell.com/ femicide_the_power_of_a_name.html (24.6.2018).

Schröttle, Monika/Müller, Ursula, 2004: Lebenssituation, Sicherheit und Gesundheit von Frauen in Deutschland. Eine repräsentative Untersuchung zu Gewalt gegen Frauen in Deutschland. Im Auftrag des Bundesministeriums für Familie, Senioren, Frauen und Jugend. Berlin.

Segato, Rita, 2010: Feminicidio y femicidio. Conceptualización y apropiación. In: Heinrich Böll Stiftung (Hg.): Feminicidio. Un fenómeno Global. De Lima a Madrid. Brüssel, 5-6.

Šimonović, Dubravka, 2015: UN Rights Expert Calls All States to Establish a 'Femicide Watch', Internet: https://www.ohchr.org/EN/NewsEvents/Pages/DisplayNews.aspx?NewsID=16796 (1.7.2018).

Tagesspiegel, 2006: Körting. Familie Sürücü sollte Deutschland verlassen. Internet: https:// www.tagesspiegel.de/berlin/nach-dem-urteil-koerting-familie-sueruecue-sollte-deutschlandverlassen/702292.html (14.7.2018).

Walby, Sylvia/Towers, Jude/Francis, Brian, 2016: Is Violent Crime Increasing or Decreasing? A New Methodology to Measure Repeat Attacks Making Visible the Significance of Gender and Domestic Relations. In: The British Journal of Criminology. 56 (6), 1203-1234. Internet: https://doi. org/10.1093/bjc/azv131 (24.6.2018).

Wir Frauen, o.J.: Geschlechtsspezifische Tötungen in Deutschland. Internet: https://wirfrauen. de/geschlechtsspezifische-toetungen-in-deutschland (1.7.2018).

World Health Organization, 2012: Femicide. Internet: http://apps.who.int/iris/bitstream/handle/ 10665/77421/WHO_RHR_12.38_eng.pdf?sequence=1 (30.6.2018).

\section{Der Zugang zu Schutz für geflüchtete Menschen: eine feministische Analyse}

ISABELLA SOPHIE ROTINO'

Zahlreiche Gesetzesänderungen haben in den letzten Jahren zu Verschärfungen des Asylrechts und zu einer Verschlechterung der Lage von geflüchteten Menschen in Deutschland geführt. Neben den weitreichenden rechtlichen Konsequenzen für die betroffenen Personen beeinflussen die Gesetzesänderungen auch die gesellschaftliche und politische Atmosphäre. Sie befeuern ein diskriminierungsförderndes Klima und wirken stigmatisierend auf Geflüchtete. Ein solches Umfeld erschwert ein friedliches, demokratisches und auf den Ideen von Gleichheit und Würde aller Menschen basierendes Zusammenleben. Damit haben diese Gesetzesänderungen auch gleichstellungspolitische Auswirkungen. So heißt es in der Stellungnahme der Bundesregierung zum Zweiten Gleichstellungsbericht, dass der Schutz und die In- 
tegration von in Deutschland schutzsuchenden Menschen eine gleichstellungspolitische Herausforderung darstelle und dass nur in einem Klima der gegenseitigen Wertschätzung die Prinzipien von Gleichheit, Freiheit und Demokratie glaubhaft vertreten werden könnten (Deutscher Bundestag 2017, 20).

Obgleich feministische Perspektiven in den letzten Jahrzehnten im Flüchtlingsrecht an Einfluss gewonnen haben und geschlechtsspezifische Aspekte weitgehend integriert wurden, gehen sie im aktuellen rechtspolitischen Diskurs zum Flüchtlingsrecht immer mehr verloren (Wessels 2018, 19). Dabei drängen sich mit dem immer restriktiver werdenden Flüchtlingsrecht neue und alte Geschlechterfragen auf. Der Beitrag stellt die These auf, dass die Gesetzesverschärfungen im Flüchtlingsrecht, die besonders den Zugang zu Schutz und die Anerkennung eines Schutzstatus betreffen, diskriminierend sind und einen Rückschritt im Bereich der Geschlechtergleichstellung bedeuten. Durch die Abschottungspolitik, die Deutschland prominent vertritt, entstehen neue und verschärfen sich bestehende Problematiken, die geschlechtsspezifische Implikationen haben. Der Zweite Gleichstellungsbericht der Bundesregierung (Deutscher Bundestag 2017) ${ }^{2}$ hat einige dieser geschlechtsspezifischen Implikationen herausgearbeitet und entsprechenden Handlungsbedarf aufzeigt. Der in jeder Legislaturperiode erscheinende Bericht ist eine Bestandsaufnahme der Gleichstellungssituation und enthält Empfehlungen für Maßnahmen der Gleichstellungspolitik für mehr Geschlechtergerechtigkeit. Das Thema Flucht wird im Zweiten Gleichstellungsbericht der Bundesregierung gerade nicht als geschlechtsneutrales Phänomen betrachtet. Vielmehr gilt Flucht als durch Erfahrungen auf und nach der Flucht geprägt, die aus Regelungen und Maßnahmen resultieren, die von einem strukturell hierarchischen Geschlechterverhältnis geformt sind (Deutscher Bundestag 2017, 224ff.).

Im Folgenden wird entlang des von der Sachverständigenkommission zum Zweiten Gleichstellungsbericht identifizierten Handlungsbedarfs in Bezug auf den Zugang zu Schutz für geflüchtete Menschen die aktuelle rechtliche und politische Situation einer feministischen Analyse unterzogen und an menschenrechtlichen Standards gemessen. Der Artikel kann so zeigen, dass bei den aktuellen rechtspolitischen Entwicklungen Menschenrechte und besonders die Menschenrechte von Frauen* und LSBTIQ*3 $^{* 3}$ auf der Strecke bleiben. Der Fokus liegt dabei auf dem Zugang zu Schutz für geflüchtete Menschen: nicht nur, weil sich die Gesetzesverschärfungen im Flüchtlingsrecht gerade darauf beziehen, sondern auch, weil der Zugang zu Schutz die Voraussetzung für die Geltendmachung universeller Menschenrechte ist - zu denen der Schutz vor Diskriminierung ebenso zählt wie die Gleichstellung der Geschlechter. Dieser Zugang zu Schutz wird mit Blick auf drei Schwerpunkte genauer analysiert: geschlechtsbezogene Fluchtgründe, sogenannte sichere Herkunftsstaaten und Familiennachzug. 


\section{Der menschenrechtsgeprägte Flüchtlingsbegriff oder: Sind Menschenrechte auch Frauen*rechte?}

Erst im 20. Jahrhundert rückte das internationale Menschrechtsregelwerk sowie das gemeinsame europäische Asylsystem der Europäischen Union (EU) das Individuum als Rechtssubjekt in den Mittelpunkt und erweiterte die Rechtsposition um einen individuellen Anspruch auf Leben und Schutz vor existenzieller Vernichtung. So verbindet der internationale Flüchtlingsbegriff der Genfer Flüchtlingskonvention (GFK) von 1951 Flüchtlingsschutz und Menschenrechtsgarantie zu einem einheitlichen subjektiven Schutzanspruch auf Aufnahme und Teilhabe im Zufluchtsstaat (Frings 2017, 100f.). Flüchtlingsschutz stellt sich somit auch als subsidiärer Menschenrechtsschutz dar (Lehnert 2014, 161f.).

Schutz nach einer Flucht kann entweder durch die Asylberechtigung nach Art. 16a Grundgesetz (GG), durch den Flüchtlingsschutz nach der GFK oder durch die Anerkennung als subsidiär schutzberechtigt gewährt werden ( $§ 3-4$ Asylgesetz (AsylG)). Durch die seit dem Asylkompromiss von 1993 in Deutschland eingeführte Drittstaatenregelung ist der Anwendungsbereich des Asylrechts nach Art. 16a GG marginal geworden. Nach dieser Regelung können in Deutschland nur diejenigen Flüchtlinge Asyl beantragen, die nicht über einen sicheren Drittstaat ${ }^{4}$ eingereist sind. Überlagert wird diese Regelung seit geraumer Zeit von dem europäischen Zuständigkeitssystem der Dublin-III-Verordnung (Zuständigkeitsverordnung Nr. 604/2013) von 2013. Sie legt fest, dass jenes EU-Land für die Bearbeitung von Asylverfahren zuständig ist, in dem die schutzsuchende Person erstmals EU-Boden betreten hat. Diese Regelung geht davon aus, dass alle EU-Staaten die gleichen rechtlichen und tatsächlichen Asylstandards gewährleisten können. ${ }^{5}$

Sowohl in Art. 16a GG als auch in Art. 1 A Nr. 2 GFK findet sich Geschlecht nicht als Fluchtgrund. Den Autor*innen dieser Normen schwebte das Bild eines jungen, öffentlich-politisch aktiven Mannes als Flüchtling vor. Dies hatte zur Folge, dass Menschenrechtsverletzungen in der privaten Sphäre - die überwiegend Frauen* betreffen - nicht als Fluchtgründe anerkannt wurden, da das Private zu einem dem staatlichen Zugriff nicht zugänglichen Raum gezählt wurde (Markard 2012, m.w.N.; Krause 2017). Diese Vorstellung entspricht allerdings mittlerweile ebenso wenig den realen Verhältnissen, wie die gegenderte Trennung öffentlich/privat oder die Idee, dass Verfolgung immer nur von staatlichen Akteuren ausgeht. Inzwischen ist unbestritten, dass Menschen auch aufgrund ihres Geschlechts verfolgt werden. Geschlecht und genderbezogene Fluchtgründe werden der Kategorie der ,sozialen Gruppe“ zugeordnet. Mit der Qualifikationsrichtlinie 2011/95/EU (QRL) der EU wurde diese Auslegung verbindliches Recht. In Art. 10 Abs. 1 lit. d QRL wird auch festgestellt, dass homo- und bisexuelle Menschen sowie Transgenderpersonen unter diese Gruppe subsumiert werden.

Gleichwohl bleibt die Subsumtion unter die ,soziale Gruppe“ genderunsensibel, da sie aufgrund ihrer „Auffangfunktion“ die speziellen Verfolgungslagen von Frauen* 
und LSBTIQ* nicht immer ausreichend erfassen kann. Erstens verlangt die Anerkennung der Flüchtlingseigenschaft oder des subsidiären Schutzes, dass die erlittene Gewalt oder die geschlechtsbezogene Verfolgung im Herkunftsstaat erfolgt sein muss. In erster Linie gehört dazu die geschlechtsbezogene Verfolgung durch staatliche Akteure (Folter, Vergewaltigung in Polizeihaft etc.). Verfolgung oder Bedrohung können allerdings auch von nichtstaatlichen Akteur*innen ausgehen, wie z.B. im Fall von Genitalbeschneidung oder Zwangsverheiratung (Art. 6 QRL bzw. § 3c Nr. 3 AsylG). Geht die Gefahr in diesen Fällen von Privatpersonen aus (Ehemännern, Familienmitgliedern etc.), setzt die Flüchtlingsanerkennung voraus, dass neben der Feststellung der Erheblichkeit der Verfolgung der Staat und seine Organe nicht willens oder nicht in der Lage sind, vor dieser Verfolgung zu schützen - unabhängig davon, ob dem Staat dieses Versagen zuzurechnen ist oder nicht (Wessel/Frings 2017, 11). Hierbei überschätzen die Gerichte nicht selten die Schutzmöglichkeiten des Staates, während sie den Einfluss der Familien bei geschlechtsbezogener Verfolgung unterschätzen. Auch wird bei der Anforderung, dass Frauen* in einem anderen Landesteil Sicherheit finden könnten, nicht ausreichend auf die tatsächlichen Existenzmöglichkeiten einer alleinstehenden und eventuell alleinerziehenden Frau abgestellt. Zweitens entpolitisiert die Subsumption unter die „soziale Gruppe“ feministischen Widerstand: Widersetzen sich Menschen einer geschlechtsbezogenen Verfolgung, so handeln sie auch politisch, was die Zuordnung zur Kategorie ,soziale Gruppe“ jedoch unterschlägt (Lehnert 2014, 168). Die Flüchtlingsanerkennung entspricht daher nur bedingt einem menschenrechtlichen und genderbewussten Flüchtlingsbegriff, der unterschiedlichen Erfahrungen von Männern* und Frauen* auf der Flucht Rechnung trägt.

Diese Annahme wird durch die Tatsache bestätigt, dass geschlechtsbezogene Verfolgung und Schädigungen auf der Flucht und außerhalb des Herkunftsstaates nach deutschem Recht unbeachtlich sind. Eine Verfolgung auf der Flucht oder im Aufnahmestaat als ein nachträglich eingetretener Fluchtgrund führt bislang nur in wenigen Ausnahmefällen zur Flüchtlingsanerkennung. § 28 Abs. 1 S. 1 AsylG besagt:

Ein Ausländer wird in der Regel nicht als Asylberechtigter anerkannt, wenn die Gefahr politischer Verfolgung auf Umständen beruht, die er nach Verlassen seines Herkunftslandes aus eigenem Entschluss geschaffen hat, es sei denn, dieser Entschluss entspricht einer festen, bereits im Herkunftsland erkennbar betätigten Überzeugung.

Hier tritt das männliche Paradigma des Flüchtlingsrechts deutlich zum Vorschein: Zugrunde gelegt wird die Vorstellung vom Flüchtling als junger, politisch aktiver Mann. Unsichtbar bleiben hingegen zahlreiche genderbezogene Fluchtgründe, die vor allem Frauen* betreffen. In den Verfahren wird nur darauf geachtet, ob im Herkunftsstaat einschlägige Gefahren zu befürchten sind. Damit werden aber die Komplexität und Dynamik von Flucht, Fluchtwegen und -erfahrungen der meisten Geflüchteten außer Acht gelassen. Auf der Flucht kann sich der Status einer geflüchteten Person mehrmals verändern. Zum Beispiel kann eine Frau* auf der Flucht 
zugleich Arbeitsmigrantin*, Fliehende vor Ausbeutung, sexueller Gewalt usw. sein. Für diese Frauen* gibt es meist kein Zurück mehr. Auch gibt es eine große Zahl an Frauen*, denen aufgrund von Trennung von ihrer Familie, des Verlusts ihres Lebenszusammenhangs, wegen Krankheit, Schwangerschaft oder der Versorgung von Kindern die Existenzgrundlage im Herkunftsland fehlt oder denen aufgrund der starken physischen und/oder psychischen Verletzungen auf der Flucht ein Überleben im Herkunftsstaat unmöglich geworden ist. Diese Bedingungen werden jedoch nicht als politische Fluchtgründe anerkannt. Aus diesem Grund empfiehlt die Sachverständigenkommission zum Zweiten Gleichstellungsbericht im Sinne eines menschenrechtlich genderbewussten Flüchtlingsbegriffs zu prüfen, ob eine Gefahr einer unmenschlichen Behandlung (Art. 3 EMRK; § 4 Abs. 1 AsylG; Art. 2 lit. f, g QRL) oder die Gefahr für Leib und Leben greift (Art. 2 Abs. 2 S. 1 GG) und damit die Abschiebung verboten und eine Aufenthaltserlaubnis erteilt werden sollte (Deutscher Bundestag 2017, 226). Die aktuellen politischen Entwicklungen deuten jedoch nicht auf eine Anerkennung nachträglich eingetretener, genderbezogener Fluchtgründe hin.

\section{,Sichere Herkunftsstaaten und die erschwerte Anerkennung geschlechtsbezogener Fluchtursachen}

Eine weitere Empfehlung der Sachverständigenkommission zum Zweiten Gleichstellungsbericht richtet sich gegen die Einstufung von Staaten als ,sichere' Herkunftsstaaten. Aus Gleichstellungsperspektive sei die Eingruppierung von Staaten als sicher und unsicher kritisch zu betrachten, da die Anerkennung von geschlechtsbedingten Fluchtursachen darüber erschwert werde. Die spezifischen Lebenslagen von Frauen* sollten daher im Rahmen des subsidiären Schutzes und bei der Prüfung von Abschiebehindernissen besonders berücksichtigt werden (Deutscher Bundestag 2017, 226). Tatsächlich ist bei der Einstufung von Staaten als ,sicher" nur die öffentliche Sphäre maßgeblich, und es wird die Perspektive der Mehrheitsbevölkerung bzw. konkreter der männlichen Bevölkerung eingenommen, wenn beispielsweise unberücksichtigt bleibt, dass der jeweilige Staat Menschenrechte gegen Frauen* und LSBTIQ* verletzt (Freedman 2007, 139ff.). Hinzu kommt, dass die Einstufung des Staates als ,sicher' nicht selten von der tatsächlichen Menschenrechtslage abweicht - auch für die männliche Bevölkerung. So berichten zahlreiche NGOs in Bezug auf Tunesien, Marokko und Algerien unter anderem von Einschränkungen der Meinungs- und Versammlungsfreiheit, von Diskriminierungen im täglichen Leben, Folter, Verfolgung von Journalist*innen und strafrechtlicher Verfolgung von LSBTIQ* (Pro Asyl 2018; Amnesty International 2017a, 2017b, 2017c).

Problematisch ist nach Ansicht der Sachverständigenkommission des Zweiten Gleichstellungsberichts die Einstufung als sicherer Herkunftsstaat für Asylsuchende auch deshalb, da sie mit einem Schnellverfahren verbunden ist (§§ 30a i.V.m. 29a AsylG). Anträge werden innerhalb einer Woche entschieden, die Fristen für das ge- 
richtliche Verfahren sind stark verkürzt (Frings 2017, 107). In diesem sehr kurzen Verfahren müssen Tatsachen und Beweismittel vorgelegt werden, um die Vermutung des ,sicheren' Herkunftsstaates zu widerlegen. Die Klage gegen den ablehnenden Bescheid ist innerhalb einer Woche zu erheben. Da die Behörde auch während des Klageverfahrens noch abschieben kann, ist es zusätzlich geboten, einen Eilschutzantrag zu stellen, um dies zu verhindern. Das bedeutet, dass nach der ablehnenden Entscheidung im Rahmen einer Woche ein immenser Arbeitsaufwand anfällt, der zugleich eine große Hürde darstellt (Wessel/Frings 2017, 8).

Aus Geschlechterperspektive wird das Schnellverfahren kritisiert, da in einem solchen Verfahren die besondere Schutzbedürftigkeit ${ }^{6}$, die sich unter anderem auf vergeschlechtlichte Aspekte wie sexualisierte Gewalt richtet, nur sehr schwer identifiziert werden kann. Frauen* und LSBTIQ* sind daher von der Ausweitung der ,sicheren' Herkunftsstaaten besonders betroffen. Betroffene von sexualisierter Gewalt oder Verfolgung aufgrund der sexuellen Orientierung haben meist gelernt, diese Verletzungen zu verdrängen und zu ,funktionieren'. In einem Schnellverfahren ist jedoch keine Zeit, um diese Traumata vorzubringen oder gar zu verarbeiten. Hinzukommt, dass es in Deutschland keine einheitlichen und flächendeckenden Verfahren zur Identifikation besonders schutzbedürftiger Personen mit Ausnahme der unbegleiteten minderjährigen Flüchtlinge gibt (Deutsches Institut für Menschenrechte 2016, 67). Die unionsrechtlichen Vorgaben zur Feststellung der Schutzbedürftigkeit (Verfahrensrichtlinie 2013/32/EU und Aufnahmerichtlinie 2013/33/EU) sind trotz Verstreichen der Frist (20. Juli 2015) nicht in nationales Recht umgesetzt worden. Die Umsetzung dieser europarechtlichen Vorgabe ist nicht zu erwarten. Im Koalitionsvertrag zwischen Christlich Demokratischer Union (CDU), Christlich-Sozialer Union (CSU) und der Sozialdemokratischen Partei Deutschlands (SPD) wurden „zum Zwecke der Verfahrensbeschleunigung“ Algerien, Marokko und Tunesien sowie weitere Staaten mit einer regelmäßigen Anerkennungsquote unter 5\% zu sicheren Herkunftsstaaten erklärt (Deutsche Bundesregierung 2018, 108). Dabei beträgt die bereinigte Schutzquote für Algerien 7,4\%, für Tunesien 6,3\% und für Marokko 10,8\% (Pro Asyl 2018). Gleichwohl verfolgt das Kabinett dieses Vorhaben weiter und fügt der Liste der, sicheren ' Herkunftsstaaten neben den Maghreb-Staaten Georgien hinzu. Wird der Bundesrat diesem Vorstoß zustimmen, würde sich die aktuelle Bundesregierung allerdings den Vorgaben des Bundesverfassungsgerichts und ihrer Verpflichtung auf faire Prüfung entziehen: Es muss landesweit und für alle Personen- und Bevölkerungsgruppen die Sicherheit vor politischer Verfolgung bestehen. Es muss unter anderem gewährleistet sein, dass im Herkunftsland keine Folter oder unmenschliche und erniedrigende Behandlung oder Bestrafung droht (BVerfG, 14.05.1996 - 2 BvR 1507/93, 1508/93). Eine Anerkennungsquote berücksichtigt allerdings nicht die konkrete Verfolgungsfreiheit von unterschiedlichen Personengruppen. 
(Kein) Familiennachzug: die menschenrechtswidrige Beschränkung des Familiennachzugs

Mit dem Familiennachzug kann ein Familienmitglied mit einem gesicherten Status Familienangehörige der Kernfamilie nachholen ( $\S 27-36$ AufenthG). Der Familiennachzug stellt eine der immer rarer werdenden Möglichkeiten der legalen Einreise dar. Die Sachverständigenkommission warnt daher vor einer Beschränkung des Familiennachzugs, um zu verhindern, dass Frauen mit Kindern mangels legaler Wege die Flucht über die gefährliche und häufig tödliche Mittelmeerfluchtroute antreten. Sie fordert daher, dass solchen geschlechtsbezogenen Implikationen von Asyl- und Grenzpolitiken entgegengewirkt wird (Deutscher Bundestag 2017, 226).

Das Gegenteil ist jedoch der Fall: Mit dem im März 2016 in Kraft getretenen Asylpaket II hat der Bundestag die Aussetzung des Familiennachzugs für subsidiär Schutzberechtigte bis März 2018 beschlossen $(\S \S 104$ Abs. 13 AufenthG; Deutsches Institut für Menschenrechte 2016, 35). Diese Frist wurde bis 31. Juli 2018 verlängert. Das bedeutet, dass es für Menschen, denen im Herkunftsstaat Folter, die Todesstrafe oder ernste Gefahr für Leib oder Leben infolge eines bewaffneten Konflikts drohen, vor August 2018 nicht möglich war, ihre engsten Familienangehörigen nach Deutschland zu holen. Auch ab August 2018 wird das Recht auf Familienleben für etliche Betroffene weiterhin ausgesetzt bleiben. CDU, CSU und SPD haben sich auf eine zahlenmäßige Beschränkung des Familiennachzugs geeinigt. Der Familiennachzug von subsidiär Geschützten soll auf den Zuzug von 1.000 Personen pro Monat begrenzt werden, nur eine Härtefallregelung ( $\S 22$ und 23 AufenthG) soll jenseits dieses Kontingents Anwendung finden (Deutsche Bundesregierung 2018, 104f.).

Eine numerische Begrenzung auf 1.000 Menschen pro Monat wird mitnichten menschenrechtlichen Verpflichtungen gerecht - denn ab der 1.001 Person kommt die Neuregelung einer faktischen Aussetzung des Familiennachzugs gleich. Die Versagung des Familiennachzugs ist jedoch grundgesetz-, europa- und völkerrechtswidrig. Das Recht auf Familiennachzug ist Teil des Rechts auf Familienleben, welches aus Art. 6 GG, Art. 8 EMRK, Art. 9, 10 und 16 UN-Kinderrechtskonvention (UNKRK) und Art. 17 des UN-Zivilpakts resultiert, und ist in Art. 10 Abs. 3a der Familienzusammenführungsrichtlinie von 2003 normiert.

Im Fall von Minderjährigen, die während der jahrelangen Wartezeiten volljährig werden, bedeutet dies ein Verlust des Rechts auf Familie (Deutsches Institut für Menschenrechte 2018). Ehefrauen und Mütter trifft diese Regelung besonders stark, denn meist treten ihre Ehemänner und älteren Söhne die Flucht vor ihnen an, während sie in den unsicheren Krisengebieten oder in prekären und gefährlichen Zwischenstationen der Flucht, wie in Flüchtlingslagern, verharren. Verschärft wird diese Situation dadurch, dass es für anerkannte unbegleitete minderjährige Flüchtlinge in Zukunft noch sehr viel schwieriger wird, Eltern und Geschwister aus Kriegs- und Krisengebieten nach Deutschland zu holen. NGOs und Beratungsstellen berichten von zahlreichen Fällen, in denen minderjährigen Geschwistern der gleichzeitige 
Nachzug mit ihren Eltern verwehrt wurde (UNHCR Deutschland 2017, 134ff.). Können die minderjährigen Flüchtlinge nicht ausreichend Wohnraum und den Lebensunterhalt sicherstellen, so erhalten die Geschwister kein Visum zum Nachzug (Auswärtiges Amt 2017, 2). Dies führt dazu, dass sich Eltern häufig aufteilen und meist die Mütter mit den kleineren Geschwistern in den Krisengebieten verbleiben. Im Koalitionsvertrag wird diese Folge gerade bezweckt: „Mit der gesetzlichen Neuregelung wollen wir Anreize ausschließen, die dadurch entstehen, dass Minderjährige von ihren Eltern unter Gefährdung des Kindeswohls zukünftig auf die gefährliche Reise vorgeschickt werden“ (Deutsche Bundesregierung 2018, 105). Damit nimmt die Bundesregierung eine menschenrechtswidrige Lage ${ }^{7}$ in Kauf, in der getrennte Familien schweren psychischen Belastungen ausgesetzt sind, Mütter mit ihren Kindern unter menschenunwürdigen Bedingungen leben müssen oder sich auf den gefährlichen Weg nach Europa machen. Gleichzeitig stellt der Status quo eine Diskriminierung von Frauen dar, die als Ehefrauen und Mütter besonders dramatisch von der Beschränkung des Familiennachzugs betroffen sind.

\section{Fazit}

Die aktuellen rechtspolitischen Entwicklungen bereiten Grund zur Sorge, dass sich die Bedingungen für geflüchtete Menschen und besonders für Frauen* und LSBTIQ* weiter verschärfen und von menschenrechtlichen Standards entfernen. Auch der Koalitionsvertrag lässt wenig hoffen. Innerhalb des Themenbereichs „,Zuwanderung“ findet sich nur an einer Stelle das Wort ,geschlechtergerecht“. Nämlich dann, wenn es darum geht, sogenannte AnKER-Einrichtungen (Ankunft, Entscheidung, kommunale Verteilung bzw. Rückführung), durch die vornehmlich eine schnelle und unkomplizierte „Rückführung“ sichergestellt werden soll, geschlechtergerecht zu gestalten (Deutsche Bundesregierung 2018, 107). Dies fügt sich ein in jenen antidemokratischen Duktus, geflüchtete Menschen als ,rechtlose Bittsteller“ und als „Bewerber um begrenzte privilegierte Plätze“ oder als „Hinzukommende, denen Zutritt bei Wohlverhalten, Bescheidenheit und Subordination unter Bewährung gewährt werden kann“, zu dehumanisieren (Frings 2017, 96). Das Stigmatisieren von Geflüchteten als Sicherheitsproblem und Bedrohung für die Aufnahmegesellschaft lässt zudem befürchten, dass es zu einer immer weiteren Vorverlagerung der EUAußengrenzen kommen wird. Kann die deutsche Grenze gar nicht erst überquert werden, so läuft das Asylrecht ins Leere, die Schutzsuchenden bleiben rechtlos und ihre Menschenrechte werden missachtet (Cremer 2018 m.w.N.). Daher sind zwar in erster Linie Gesetzgebung, Rechtsprechung und die damit befassten Behörden angehalten, die Vorgaben der Menschenrechtsverträge zu beachten und umzusetzen, damit Menschenrechte zu ihrer vollen Geltung gelangen können. Aber auch wissenschaftliche und politische Akteur*innen sind aufgefordert, einer feministischen Strategie folgend, Geschlechterfragen in das Flüchtlingsrecht zu integrieren, der diskriminierenden und menschenrechtswidrigen Situation entgegenzuwirken und sich 
für ein humanes, den Bedürfnissen der schutzsuchenden Menschen entsprechendes, System einzusetzen.

\section{Anmerkungen}

1 Ich möchte Regina Frey danken, die den Entstehungsprozess dieses Beitrages angestoßen und unterstützt hat.

2 Mehr Informationen unter www.gleichstellungsbericht.de

3 Lesbisch, Schwul, Bi, Trans*, Inter* und Queer

4 Nach BVerfGe 94, 49ff. sind alle EU-Staaten sichere Drittstaaten.

5 Zahlreiche Nichtregierungsorganisationen (NGO) und Menschenrechtsberichte sowie einige Gerichte bezweifeln dies jedoch.

6 Art. 21 Richtlinie 2013/33/EU: Traumata infolge von Folter, Vergewaltigung oder sonstige Formen schwerer psychischer und physischer oder sexualisierter Gewalt, Menschen mit Behinderungen, Minderjährige, Schwangere, ältere Menschen, Alleinerziehende, Opfer von Menschenhandel, Personen mit schweren körperlichen Erkrankungen, mit psychischen Störungen und Opfer der Verstümmelung weiblicher Genitalien.

7 Diese Lage widerspricht dem Grundsatz des Vorrangs des Kindeswohls aus der UN-KRK sowie Art. 10 Abs. 1 UN-KRK, wonach Vertragsstaaten gehalten sind, zum Zweck der Familienzusammenführung gestellte Anträge .,wohlwollend, human und beschleunigt" zu bearbeiten, sowie Art. 9 UN-KRK, nach dem die Familienzusammenführung nicht zu einer Trennung von anderen Kindern von ihren Eltern führen darf.

\section{Literatur}

Amnesty International, 2017a: Algerien. Jahresbericht 2017. Internet: https://www.amnesty.de/ jahresbericht/2017/algerien (18.7.2018).

Amnesty International, 2017b: Marokko und Westsahara. Jahresbericht 2017. Internet: https:// www.amnesty.de/jahresbericht/2017/marokko-und-westsahara (18.7.2018).

Amnesty International, 2017c: Tunesien. Jahresbericht 2017. Internet: https://www.amnesty.de/ jahresbericht/2017/tunesien (18.7.2018).

Auswärtiges Amt, 2017: Familiennachzug zum unbegleiteten minderjährigen Flüchtling. Runderlass vom 20.3.2017. Geschäftszeichen: 508-3-543.53/2. Internet: https://www.proasyl.de/wp-content/uploads/2015/12/2017-03-20-Runderlass-Ausw\%C3\%A4rtiges-Amt-Geschwisternachzug. pdf (8.9.2018).

Cremer, Hendrik, 2018: Zurückweisungen von Flüchtlingen an der Grenze? Eine menschen- und europarechtliche Bewertung. Berlin.

Deutsche Bundesregierung, 2018: Ein neuer Aufbruch für Europa - Eine neue Dynamik für Deutschland - Ein neuer Zusammenhalt für unser Land. Koalitionsvertrag zwischen CDU, CSU und SPD. 19. Legislaturperiode. Berlin.

Deutscher Bundestag, 2017: Zweiter Gleichstellungsbericht der Bundesregierung. Drucksache 18/12840. Berlin.

Deutsches Institut für Menschenrechte, 2016: Entwicklung der Menschenrechtssituation in Deutschland. Januar 2015 - Juni 2016. Bericht an den Deutschen Bundestag gemäß § 2 Absatz 5 DIMRG. Berlin.

Deutsches Institut für Menschenrechte, 2018: FAQ Familiennachzug. Internet: https://www.institut-fuer-menschenrechte.de/themen/asylflucht/familiennachzug/faq-familiennachzug/\#c21951 (19.7.2018). 
Freedman, Jane, 2007: Gendering the International Asylum and Refugee Debate. London.

Frings, Dorothee, 2017: Flüchtlinge als Rechtssubjekte oder als Objekte gesonderter Rechte. In: Ghaderi, Cinur/Eppenstein, Thomas (Hg.): Flüchtlinge. Multiperspektivische Zugänge. Wiesbaden, 95-111.

Krause, Ulrike, 2017: Die Flüchtling - der Flüchtling als Frau. Genderreflexiver Zugang. In: Ghaderi, Cinur/Eppenstein, Thomas (Hg.): Flüchtlinge. Multiperspektivische Zugänge. Wiesbaden, 79-94.

Lehnert, Matthias, 2014: Geschlecht und Menschenrechte von Flüchtlingen. In: Lembke, Ulrike (Hg.): Menschenrechte und Geschlecht. Baden-Baden, 160-187.

Markard, Nora, 2012: Kriegsflüchtlinge. Gewalt gegen Zivilpersonen in bewaffneten Konflikten als Herausforderung für das Flüchtlingsrecht und den subsidiären Schutz. Tübingen.

Pro Asyl, 2018: ,Sichere' Herkunftsstaaten. Internet: https://www.proasyl.de/thema/von-wegensicher/ (18.7.2018).

UNHCR Deutschland, 2017: Familienzusammenführung zu Personen mit internationalem Schutz. Rechtliche Probleme und deren praktische Auswirkungen. Beiträge aus dem Asylmagazin. In: Informationsverbund Asyl \& Migration. (4), 132-137. Internet: http://www.unhcr.org/dach/ wp-content/uploads/sites/27/2017/06/AM17-4_thema_famzus.pdf (4.7.2018).

Wessel, Barbara/Frings, Dorothee, 2017: F.A.Q. häufig gestellte Fragen an der Schnittstelle Gewaltschutz und Flucht. Berlin.

Wessels, Janna, 2018: Feministische Herausforderungen an das Flüchtlingsrecht: von der zweiten zur dritten Welle. In: GENDER - Zeitschrift für Geschlecht, Kultur und Gesellschaft. 10 (2), 18-31.

\title{
Trans Studies \& Feminismen - Reibungen, Brüche ... und Allianzen?
}

\author{
PERSSON PERRY BAUMGARTINGER
}

Vor kurzem hielt der österreichische Verfassungsgerichtshof in seiner Erkenntnis aufgrund der Klage einer intergeschlechtlichen Person fest, dass Österreich im Personenstand einen weiteren Eintrag neben Mann und Frau zulassen muss. Kurz davor wurde bekannt, dass Trans in der revidierten elften Ausgabe des International Classification of Diseases and Related Health Problems (ICD), herausgegeben von der Weltgesundheitsbehörde (WHO), nicht mehr unter der bisherigen Bezeichnung „Transsexualismus“ in der Rubrik „Psychische und Verhaltensstörung“, sondern als „gender incongruence“ in der Rubrik „,conditions related to sexual health“ genannt sein soll. Die beiden Erfolge wurden in den (sozialen) Medien gefeiert. Zur gleichen Zeit wurde am 8. Juli 2018 die Pride in London von sogenannten Trans-Exclusionary Radical Feminists (TERFs) mit expliziten Anti-trans-Transparenten und -Flyern angeführt. In einigen Ländern agitieren derzeit TERFs gegen Geschlechtseintragsänderungen, etwa in Neuseeland und UK, oder werfen der TransBewegung vor, Teil 
der ,Alt-Right“-Bewegung zu sein, womit die TransBewegung diffamiert und ins ,rechte Eck' gestellt werden soll. Während also einerseits zentrale jahrelang erkämpfte Trans- und Inter-Forderungen (teilweise) erfüllt werden, erinnern die Reaktionen der TERFs an die Angriffe aus Zeiten, in denen die Trans Studies entstanden sind. ${ }^{1}$ Da die feministische Anti-trans-Haltung wieder zu erstarken droht, lohnt es sich, die Entstehung der Trans Studies, ihren gesellschaftlichen Kontext, ihre theoretischen Bezüge und aktivistischen Kämpfe genauer zu beleuchten. Denn der Widerstand gegen solche Anti-trans-Logiken ist einer der zentralen Ausgangspunkte der Trans Studies. Sie bringen eine Infragestellung von Trans/Geschlechtlichkeit hervor, die bis heute die feministische und Geschlechterforschung prägen. Gleichzeitig ist eine Differenziertheit, wie beispielsweise in kritischen intersektionalen Ansätzen, insbesondere bei den heute wieder aufkommenden Anti-trans-Debatten sowie dem erstarkenden Rechtsrutsch notwendig.

\section{Die Ausgangssituation: das Transsexualismus/Transsexualitäts-Paradigma und Anti-trans-Handlungen}

Die Trans Studies entstanden in einem sehr heterogenen und widersprüchlichen Umfeld: Einerseits können die Trans*Wissenschaftler_innen auf Forschungsrichtungen aufbauen, die ab den späten 1960er-Jahren und vor allem in den 1970er-Jahren beginnen, die Natürlichkeit von Geschlecht infrage zu stellen. Gestützt werden sie von bereits Erreichtem der Trans*Selbsthilfegruppen und -Bewegung, die sich in den USA seit den 1950er-Jahren gegenseitig unterstützen, vernetzen und nach und nach in die Öffentlichkeit gehen. Andererseits ist das „,Transsexualismus/TranssexualitätParadigma“ (Baumgartinger 2017a, 144ff.) in vollem Umfang aktiv. Das Paradigma wird insbesondere von medizinischer, psych*ischer ${ }^{2}$ und sexualwissenschaftlicher Seite gestützt und naturalisiert die Zweigeschlechterordnung. Es konstruiert Trans als krank und unnatürlich, aber als mit somatischen und/oder psychischen Methoden heilbar. Damit bietet das Paradigma einen machtvollen Rahmen für die Pathologisierung und Kriminalisierung von Trans(-sexualität) sowie Anti-trans-Theorien und für Ausschlüsse von TransPersonen. Das Paradigma verändert sich im Laufe der Zeit nur geringfügig und ist bis heute wirksam (vgl. Baumgartinger 2017b).

Ebenso werden Trans*Personen, vor allem TransFrauen, von Feministinnen scharf angegriffen und aus sozialen Räumen ausgeschlossen, insbesondere innerhalb des essentialistischen, radikalen und lesbisch-separatistischen Feminismus (vgl. Bettcher 2016). Diese Anti-trans-Haltung manifestiert sich etwa in der Veröffentlichung "The Transsexual Empire: The Making of the She-Male“ von Janice Raymond (1979). Es gibt aber auch vor Raymonds Text schon ähnliche Anti-trans-Handlungen und -Theorien: etwa den Ausschluss von Beth Elliot von der lesbischen Bürgerinnenrechtsorganisation „Daughters of Bilitis“ und die kontroverse Diskussion, die 1973 rund um ihre Teilnahme an der West Coast Lesbian Feminist Conference in Los Angeles stattfindet, einer der ersten bekannten feministischen Angriffe auf Trans- 
Frauen. Auf dieser Tagung wirft Robin Morgan Elliot vor, sie sei ,an opportunist, an infiltrator, and a destroyer - with the mentality of a rapist" (Morgan 1973, zit.n. Bettcher 2016, 3). Der Vorwurf von Feministinnen an Trans*Frauen, sie würden durch ihr Trans*Sein Frauen Gewalt antun und seien Verräter_innen oder Vergewaltiger (sic) findet sich auch in Mary Daly’s „Gyn/Ecology“ von 1978 und in vollem Umfang in Raymonds oben genanntem Text (vgl. Meyerowitz 2002, 259-260; Stryker 2008, 102-105). Solche Ausschlüsse von Trans*Frauen aus Frauenräumen und Anti-trans-Theorien finden sich auch heute noch in feministischen wissenschaftlichen und aktivistischen Diskussionen, sowohl im angloamerikanischen wie auch im europäischen Bereich (vgl. u.a. Koch-Rein 2009). Zuletzt finden wir diese Vorwürfe in etwas aktuellerem sprachlichen Gewand von TERFs dieses Jahr auf der Pride in London: Sie leiten die Pride mit transfeindlichen Transparenten an und verteilen Flyer, die u.a. TransFrauen als heterosexuelle Männer sowie als Vergewaltiger bezeichnen und die TransBewegung als Konversionstherapie für Lesben darstellen, die das Ziel verfolge, Lesben auszulöschen (Get the L Out o.J.). Insbesondere die Reaktion auf Raymonds Text, aber auch auf das oben skizzierte Paradigma führten zu den ersten Texten der Trans Studies.

\section{Aktivistische Basis: Empowerment durch Selbsthilfegruppen und Vernetzung}

Spätestens seit den 1950ern treffen sich in den USA immer mehrTransvestit*en in kleineren und größeren Gruppen, vernetzen sich, es entstehen Trans*Selbsthilfegruppen. Sie sind ein Austausch- und Unterstützungsnetzwerk, das sowohl innerhalb der Gruppen und der Struktur, aber auch nach außen hin wirksam ist: Insbesondere von Virginia Prince ist bekannt, dass sie mit dem Psychiater Robert Stoller der University of California, Los Angeles in Verbindung steht und es wechselseitige Einflüsse, etwa in der Entwicklung des trans/gender-Konzeptes gibt (vgl. Stryker 2015). Die zunehmende Vernetzungstätigkeit führt von einer Vereinzelung weg zu einem gröBeren Selbstverständnis und stärkt einzelne TransPersonen wie auch die TransBewegung - auch wenn die Gruppen sich selbst vielleicht nicht als politisch oder aktivistisch sehen. So entstehen mit den Jahren immer mehr Community-Zeitschriften, die Austausch, Informationsvermittlung und Diskussionen auf eine neue Ebene heben. Darüber hinaus gibt es Vernetzungen zwischen Trans*- und Inter*Personen, aber auch Queers, da sie auf zahlreiche ähnliche Erfahrungen mit staatlicher und medizinischer Unterdrückung, Pathologisierung und Verleumdungs- und Verschweigensstrategien zurückblicken. Es geht um Kämpfe gegen Pathologisierung und Kriminalisierung von etablierter wissenschaftlicher Seite sowie gegen Angriffe und Verleumdung von feministischer wissenschaftlicher und aktivistischer Seite (für eine detailliertere Darstellung Baumgartinger 2017a). Zusätzlich finden innerhalb der Trans*Communitys der USA im Laufe der 1980er-Jahre starke Auseinandersetzungen um Trans*Identitäten, deren Begriffe, ihre Konkretisierung und Verwendung 
statt (vgl. Stryker 2015). Weitere Konflikte finden in den 1980ern zwischen Feministinnen und Trans*-, aber auch Inter*- und genderqueeren Personen statt und die bisher konstante Kategorie ,Frau“ wird von verschiedenen Seiten kritisiert und einer Neuauflage unterzogen.

Das Erstarken der TransBewegung kann als Empowerment der TransWissenschaftler_innen, die trans*aktivistischen Auseinandersetzungen, auch mit Wissenschaftler_innen, können als Beitrag zur Infragestellung von binären Geschlechternormen gesehen werden.

\section{Theoretische Bezüge: intersektionale feministische Kritik}

Die Kategorie Geschlecht wird - so zeigen folgende drei Ansätze - erstens in den 1970er- und 1980er-Jahren als Analysekategorie in die Forschung verstärkt eingeführt und zweitens kritisch und politisch als Werkzeug zur Veränderung von Wissenschafts- und Gesellschaftsparadigmen verwendet sowie drittens in ihrer bisherigen engen Vorstellung infrage gestellt. Eine wichtige Basis der Trans Studies sind feministische, heute sogenannte intersektionale, kritische race/gender/sexualityTheorien, die sich an rigiden Geschlechtervorstellungen und insbesondere der Kategorie ,Frau' abarbeiten (vgl. Combahee River Collective 1977/2000; Anzaldúa 1987; Rubin 1990/2011 u.v.m.).

Die Anthropologin Gayle Rubin (1990/2011) entwickelt in ihrem Artikel „The Traffic in Women" von 1975 die Theorie des sex 3 /gender-Systems. Mit dem sex/genderSystem entwirft Rubin einen alternativen Begriff für das feministische Konzept des Patriarchats, um den Ort der Unterdrückung von Frauen wie auch von sexuellen Minderheiten und bestimmter Aspekte der menschlichen Persönlichkeit zu beschreiben. Rubin schlägt damit vor, Geschlecht, race und Sexualität nicht als isolierte Phänomene, sondern als miteinander verschränkte in ihrem jeweiligen Kontext zu analysieren. Denn sexuelle und Geschlechtersysteme unterliegen unter anderem auch ökonomischen und politischen Logiken, die in die Analyse miteinbezogen werden müssen. In diesem Sinn verbindet Rubin John Moneys gender-Konzept mit der Reproduktions-Diskussion von Karl Marx, der Analyse von Verwandtschaftsverhältnissen von Claude Lévi-Strauss, Sigmund Freuds Theorien zu Frauen/Weiblichkeit und Jacques Lacans Interpretation von Freud.

Die Psycholog_innen Suzanne J. Kessler und Wendy McKenna gehen in „Gender: An Ethnomethodological Approach“ (1978) mit Harold Garfinkel (1967) davon aus, dass Geschlecht sozial konstruiert ist und, unabhängig von den körperlichen Genitalien, über die Wahrnehmung der sogenannten „kulturellen Genitalien“ von außen festgemacht wird. Ihr Konzept der „gender attribution“ beschreibt den Prozess, durch den wir jeder Person, mit der wir auf welche Weise auch immer zu tun haben, ein Geschlecht zuschreiben - unabhängig von ihrem körperlichen Geschlecht, nur aufgrund von meist unbewussten gesellschaftlichen Regeln und Vorannahmen im Moment der jeweiligen Interaktion. Gleichzeitig wird mit jeder dieser Interaktionen 
eine scheinbare Natürlichkeit von Geschlecht hergestellt und festgeschrieben - was den Eindruck erweckt, Geschlecht im Sinne von Mann und Frau wäre schon immer so gewesen. Diesen Herstellungsprozess von Geschlecht und seine anscheinende Natürlichkeit mache Trans(-sexualität), so die beiden Autor_innen, sichtbar (Kessler/McKenna 1978; s.a. Stryker/Whittle 2006, 165ff.).

In den 1980er-Jahren veröffentlicht die Historikerin Joan Scott (1986) den Artikel „Gender: A Useful Category of Historical Analysis“, den Susan Stryker (2015) als eine zentrale Grundlage für die Entstehung der Trans Studies sieht. Scott fasst darin verschiedene Konzeptionen von gender in geschichtswissenschaftlichen Forschungsrichtungen zusammen. Zentral ist ihr Text, da sie gender als analytische Kategorie stark macht und die politischen Möglichkeiten intersektionaler Forschung hervorhebt. Denn in den von ihr beschriebenen feministischen Theorien der 1970erund 1980er-Jahre wird durchgehend betont, dass erst die Verbindung mindestens der drei Kategorien class, race und gender, aber auch von Sexualität, eine Analyse gesellschaftlicher Unterdrückung (nicht nur) von Frauen möglich macht (vgl. Scott 1986; Stryker 2015).

\section{Trans Studies: selbstbestimmte, politische Forschung als Antwort}

Bei der Entstehung der Trans Studies spielen Selbstbestimmung und Widerstand gegen verschiedene Formen der (systematischen) Diskriminierung eine zentrale Rolle, während sie auf einer erstarkenden TransBewegung sowie aufkommenden Infragestellungen der Kategorie Geschlecht aufbauen können. Ende der 1980er-Jahre entstehen zwei Manifeste, die zu Beginn der 1990er-Jahre veröffentlicht und als Anfang der neuen Wissensformation Trans Studies gesehen werden können (vgl. Stryker 2015).

Als Startpunkt der Trans Studies gilt Sandy Stones posttranssexuelles Manifest (1991), eine direkte Reaktion auf die feministischen Anti-trans-Aktionen und -Theorien. Gleichzeitig bezieht sich Stone in ihrer Theorie der Posttranssexualität auf ihr aktivistisches und akademisches Umfeld von Queer-Feminist_innen und Feminist_innen of Color wie Donna Haraway, Gloria Anzaldúa, Teresa de Lauretis und Angela Davis (vgl. u.a. sterneck.net o.J.; Bettcher/Garry 2009). Stone gilt als die Erste, die die Verbindung von gender-Theorien, intersektionaler Analyse und queer-feministischer Bewegung auf das Thema Trans(-sexualität) anwendet (vgl. Stryker 2015). Sie ruft zu einem Ende der Unsichtbarmachung von Trans durch das psychomedizinische Regime auf, zu einem Ende der pathologischen psychomedizinischen Behandlungen von Transsexuellen und damit zu einer Posttranssexualität, die Trans*Lebensweisen sichtbar macht, sich in den Diskurs wieder einschreibt und das damals vorherrschende Paradigma ändert, anstatt von ihm zum Schweigen gebracht zu werden.

Etwa zur gleichen Zeit nimmt Leslie Feinberg in xierem ${ }^{4}$ Text „Transgender Liberation: A Movement Whose Time Has Come“ (1992) die pan-geschlechtliche 
Konkretisierung des Begriffs Transgender von Holly Boswell auf. Xier formuliert Transgender als eine militante, politisierte und anti-identitäre Position, die alle minorisierten geschlechtlichen Lebensweisen bündeln soll. Feinberg verbindet dafür Marxismus, Feminismus und Ansätze der gerade entstehenden neuen Queer-Bewegung ${ }^{5}$ und bringt damit einen links-politischen Aspekt in die Trans*Bewegung ein (vgl. Stryker 2015).

Aus meiner Sicht sind zwei weitere Texte zentral für die Trans Studies, auch sie arbeiten sich an dem Transsexualismus/Transsexualitäts-Paradigma sowie den feministischen Anfeindungen ab.

Kate Bornstein etwa nimmt in xierem Buch „Gender Outlaw: On Men, Women, and the Rest of Us“ (1994) unter anderem kritisch Bezug auf Raymond und die Kämpfe zwischen Feministinnen und Trans*Personen und bindet sie in xiere Theorie der „gender defenders“ bzw. „gender terrorists“ (ebd., 74) ein. Mit diesen Begriffen beschreibt Bornstein Personen, die das vorherrschende Geschlechtersystem mit feindseligen und gewaltvollen Mitteln verteidigen und damit die Gewalt männlicher Privilegien mit all ihren gesellschaftlichen und sozialen Folgen aufrechterhalten (vgl. ebd., 71-85). Xier beschreibt in diesem Buch darüber hinaus, dass nicht , die Kultur ${ }^{6}$ den Menschen ihre Rolle je nach anscheinend natürlichem Geschlecht zuweist, sondern vielmehr erst die Rollen, die Menschen spielen, Geschlecht produzieren (vgl. Stryker/Whittle 2006, 236).

Susan Strykers Text „My Words to Victor Frankenstein above the Village of Chamounix: Performing Transgender Rage“ (1994) ist ebenfalls eine Reaktion auf transfeindliche Ansätze in Wissenschaft und Gesellschaft. Stryker verbindet darin Stones Ansatz der Posttranssexualität mit Mary Shellys Romanfigur Frankenstein und kritischer Queer-Theorie (Stryker/Whittle 2006, 244). Sie vergleicht den trans(sexuellen) Körper und dessen Modifikationen, aber auch die stigmatisierende gesellschaftliche Wahrnehmung mit jenen von Frankenstein und ruft Trans*Personen dazu auf, sich die gegen sie verwendeten Begriffe wie „Kreatur“, „Monster“ oder ,unnatürlich“ anzueignen, um die gesellschaftliche Stigmatisierung und Objektivierung von Trans*Personen zu beenden. Stryker bringt mit der Strategie des Aneignens von stigmatisierenden Begriffen und Praktiken in die Trans Studies den Fokus auf Empowerment ein und darauf, selbst (forschendes) Subjekt zu sein, statt wie bisher zum (beforschten) Objekt gemacht zu werden. Weiters setzt sie - wie Bornstein - Wut als Grundlage aktivistischer Widerstände zentral. Gleichzeitig grenzt sie sich über die Strategie der Aneignung von transfeindlichen feministischen Angriffen ab und gibt Trans*Personen ein Werkzeug für politische, wissenschaftliche und individuelle Kämpfe in die Hand. Damit nutzt Stryker erstmals die aufkommenden Trans Studies explizit als Tool, um zu widerstehen, sich zu wehren, aufzustehen und in der Bestimmung über den eigenen Körper, die eigene Psyche, die eigenen Rechte und das Wissen über Trans* als Subjekt mitzubestimmen.

Die ersten Trans Studies-Texte, die aus politisch-aktivistischem Widerstand gegen Anti-trans-Ansätze entstehen, zeigen bereits grundlegende Beiträge der heutigen 
queer-/feministischen und Geschlechterforschung. Bereits im oben genannten Text betont Stone, dass die Unterdrückung von Trans* zurückgeführt werden kann auf die gesellschaftliche Zweigeschlechterordnung sowie darauf, dass die Kategorien Mann und Frau sozial konstruiert sind und unterdrückend wirken. Ein Umstand, der gerade in den Gender und Queer Studies übersehen wird; die zweite These wird heute allgemein den Queer-Theorien zugeordnet, obwohl die Trans Studies seit Ende der 1980er-Jahre dazu arbeiteten (vgl. u.a. Stone 1991; Stryker/Whittle 2006; Bettcher/ Garry 2009; Stryker 2015; Bettcher 2016). Dies gilt auch für Bornsteins Theorie, dass Geschlechterrollen nicht zugewiesen, sondern vielmehr hergestellt werden was später hauptsächlich Judith Butlers Performativitätstheorie zugeschrieben wird.

\section{Ausblick}

Leider gibt es weiterhin fremdbestimmte pathologisierende und kriminalisierende Forschung und Praktiken in den Wissenschaften ebenso wie TERF-Aktivismen. Die feministische und Geschlechterforschung - wie auch teilweise die Trans Studies haben ihre grundlegende Kategorie Geschlecht im Laufe der Zeit zu einem eindimensionalen Bild von weißen ${ }^{6}$, heterosexuellen, nichtbehinderten privilegierten Frauen/ TransPersonen/Menschen aus der Mittel- oder Oberschicht mit durchschnittlichem bis hohem Einkommen extrahiert, das bis heute größtenteils einen mehrdimensionalen, intersektionalen Zugang zu Trans-/Geschlechtlichkeit vermissen lässt. Dieser einseitige Blick ist insbesondere in Zeiten des Rechtsrutsches allgemein und einer erstarkenden TERF-Bewegung gefährlich, weil er eindimensionale, herrschaftskonforme Zugänge stärkt, anstatt differenzierte Debatten - die einer tatsächlichen gesellschaftlichen Vielfalt und ihren Verwobenheiten Raum geben - zu führen.

Wie bei ihrer Entstehung beschäftigen sich auch heute Ansätze der Trans Studies mit Intersektionen und Verwobenheiten der (trans-)geschlechtlichen Diskriminierungsstrukturen mit anderen unterdrückenden Mechanismen wie Rassismus, Pathologisierung, Be-Hinderung, (sozialstaatlichen) Wohlfahrtssystemen, Kriminalisierung und Gefängnissystemen, staatlicher Verwaltung, Regieren und Regiert-Werden (Stichwort gouvernementalité), Rechtssystemen sowie Ein- und Ausschlüssen aus der aktuellen Trans*Bewegung und ihren Forderungen (vgl. u.a. Haritaworn 2005; Spade/Whang 2004; Koyama 2006; Haritaworn/Kuntsman/Posocco 2014; Ellison et al. 2017). Diese Ansätze beziehen sich weiterhin auf feministische Theorien, sind hochaktuell, stoßen derzeit äußerst notwendig Debatten an und sollten von der feministischen wie auch der Geschlechterforschung (endlich) ernst genommen werden. Nicht im Sinne eines „Token-T“, indem Trans, TransPersonen oder Trans-Theorien als Exempel für die eigene Theorie oder die eigene Karriere benutzt werden. Sondern als zentraler Bestandteil der Geschlechterforschung: Denn als solcher liefert er seit Jahrzehnten grundlegende Beiträge und reißt - durch das Einnehmen eines eigenen Blickwinkels - aktuell notwendige, kritische Diskussionen innerhalb der Geschlechterforschung wie auch darüber hinaus gesellschaftsrelevante Aspekte an. 


\section{Anmerkungen}

1 Ich fokussiere in diesem Text auf den US-amerikanischen Bereich, ähnliche Entwicklungen im europäischen Kontext zeige ich in meinem Buch „Trans Studies“ auf (Baumgartinger 2017a).

2 „Psych*“ steht für alle drei Forschungs- und Praxisfelder Psychiatrie, Psychologie und Psychotherapie, wenn sie sich inhaltlich für das angesprochene Themenfeld nicht grundlegend unterscheiden.

3 Rubin verbindet mit dem Begriff sex sowohl Geschlechtsidentität, sexuelles Verlangen und sexuelle Fantasie wie auch Kindheitskonzepte und sieht sex als gesellschaftliches Produkt an.

4 Feinberg bezeichnet sich im Englischen mit den Pronomen „ze“ statt „he“ oder "she“. Um dem im Deutschen gerecht zu werden, verwende ich die deutsche Version ..xier“ von Anna Heger (2013). Zu Trans*Sprachvarianten und dem Thema Sprache \& Macht s. u.a.: Verein ][diskursiv 2011; Baumgartinger 2008.

5 Die neue Queer-Bewegung entsteht größtenteils aus dem Aktivismus während der AidsKrise - einer Bewegung, die sich gegen Heteronormativität richtet und Kritik an sexuellen Identitätspolitiken, der Beziehung zwischen lesbischem Feminismus und schwuler Befreiungspolitik und den verschiedenen Kategorien, über die damals Communitys, Körper und Lebensentwürfe gedacht werden, übt (vgl. u.a. Stryker 2015).

6 In Anlehnung an Eggers et al. (2005) verwende ich weiß klein und kursiv geschrieben. Der Begriff bezeichnet keine Identität, vielmehr ist er ein analytischer Begriff, der das System weißer Macht- und Dominanzverhältnisse sowie rassistischer Praktiken und Systeme benennt und sichtbar macht.

\section{Literatur}

Anzaldúa, Gloria, 1987: Borderlands/La Frontera. The New Mestiza. San Francisco, CA.

Baumgartinger, Persson Perry, 2008: Lieb[schtean] Les[schtean], [schtean] du das gerade liest... Von Emanzipation und Pathologisierung, Ermächtigung und Sprachveränderungen. In: Liminalis: Zeitschrift für geschlechtliche Emanzipation. (2), 24-39.

Baumgartinger, Persson Perry, 2017a: Trans Studies. Historische, begriffliche und aktivistische Aspekte. Wien.

Baumgartinger, Persson Perry, 2017b: Staatliche Regulierung von Geschlecht als Zweigeschlechterkonstrukt: Kritische Diskurshistorische Dispositivanalyse des Zwei-GeschlechterDispositivs anhand des sog. .Transsexuellen-Erlasses" 1980-2010 in Österreich. Unveröff. Dissertation, Univ. Wien.

Baumgartinger, Persson Perry, 2017c: Dispositiv-Reparatur statt Paradigmenwechsel - Über das .Konservieren“ des ZweiGeschlechterdispositivs durch die staatliche Regulierung von Trans* in Österreich. In: OBST Osnabrücker Beiträge zur Sprachtheorie. (91), 59-86.

Bettcher, Talia, 2016: Intersexuality, Transgender, and Transsexuality. In: Disch, Lisa/Hawkesworth, Mary (Hg.): The Oxford Handbook of Feminist Theory. Oxford, 407-427.

Bettcher, Talia/Garry, Ann, 2009: Introduction. In: Hypatia. A Journal of Feminist Philosophy. Special Issue: Transgender Studies and Feminism: Theory, Politics, and Gendered Realities. 24 (3), 1-10.

Bornstein, Kate, 1994: Gender Outlaw. On Men, Women, and the Rest of Us. New York.

Combahee River Collective, 1977/2000: The Combahee River Collective Statement. Datiert auf April 1977; u.a. abgedruckt in: Smith, Barbara (Hg.), 2000: Home Girls. A Black Feminist Anthology. 2. Aufl. New Brunswick, NJ, 264-274. 
Daly, Mary, 1978: Gyn/Ecology. The Metaaethics of Radical Feminism. Boston.

Eggers, Maureen Maisha/Kilomba, Grada/Piesche, Peggy/Arndt, Susan, 2005: Mythen, Masken und Subjekte. Kritische Weißseinsforschung in Deutschland. Münster.

Ellison, Treva/Green, Kai M./Richardson, Matt/Snorton, Riley C., 2017: We Got Issues. Toward a Black Trans*/Studies. TSQ Transgender Studies Quarterly. 4 (2), 162-169.

Feinberg, Leslie, 1992: Transgender Liberation. A Movement Whose Time Has Come. New York. Garfinkel, Harold, 1967: Studies in Ethnomethodology. Englewood Cliffs, NJ.

Get the L Out, o.J.: Internet: https://getthelout.wordpress.com (23.7.2018).

Heger, Anna, 2013: Xier packt xiesen Koffer. ComicZineHeftchen über Pronomen ohne Geschlecht. o.A.

Haritaworn, Jinthana, 2005: Queerer als wir? Rassismus. Transphobie. Queer Theory. In: Yekani, Elahe Hashemi/Michaelis, Beatrice (Hg.): Quer durch die Geisteswissenschaften: Perspektiven der Queer Theory. Berlin, 216-237.

Haritaworn, Jin/Kuntsman, Adi/Posocco, Silvia (Hg.), 2014: Queer Necropolitics. New York.

Kessler, Suzanne J./McKenna, Wendy, 1978: Gender. An Ethnomethodological Approach. Chicago, London.

Koch-Rein, A., 2009, Wissen schafft Geschlecht. Transgender Studies als akademisches Feld. In: an.schläge. Das feministische Magazin. Juni, 20-21.

Koyama, Emi, 2006: Whose Feminism Is It Anyway? The Unspoken Racism of the Trans Inclusion Debate. In: Stryker, Susan/Whittle, Stephen (Hg.): The Transgender Studies Reader. New York, 698-705.

Meyerowitz, Joanne, 2002: How Sex Changed. A History of Transsexuality in the United States. Cambridge, MA.

Raymond, Janice, 1979: The Transsexual Empire. The Making of the She-Male. Boston, MA.

Rubin, Gayle, 1990/2011: The Traffic in Women. In: Rubin, Gayle: Deviations. A Gayle Rubin Reader. Durham, London, 33-65.

Scott, Joan, 1986: Gender. A Useful Category of Historical Analysis. In: The American Historical Review. 91 (5), 1053-1075.

Spade, Dean/Whang, Sel, 2004: Transecting the Academy. In: GLQ. A Journal of Lesbian and Gay Studies. 10 (2), 240-253.

sterneck.net, o.J.: Publication History. Internet: http://www.sterneck.net/gender/stone-posttranssexuel/index.php (1.7.2018).

Stone, Sandy, 1991: The Empire Strikes Back. A Posttranssexual Manifesto. In: Straub, Kristina/ Epstein, Julia (Hg.): Body Guards. The Cultural Politics of Gender Ambiguity. New York, 280-304.

Stryker, Susan, 1994/2006: My Words to Victor Frankenstein Above The Village of Chamounix: Performing Transgender Rage. In: Stryker, Susan/Whittle, Stephen (Hg.): The Transgender Studies Reader. New York, 244-256.

Stryker, Susan, 2008: Transgender History. Berkeley, CA.

Stryker, Susan, 2015: Transgender Studies: Histories and Futures of the Field. Vortrag im Rahmen der Gender Talks, Univ. Wien/Akademie der bildenden Künste Wien, 9.6.2015. Unveröff. Manuskript.

Stryker, Susan/Whittle, Stephen (Hg.), 2006: The Transgender Studies Reader. New York.

Verein ][diskursiv, 2011: Sprachliches Handeln und Diskriminierung. In: migrazine.at - online magazin von migrantinnen für alle. Internet: http://www. migrazine.at/artikel/sprachliches-handeln-und-diskriminierung (1.7.2018). 


\title{
TAGESPOLITIK
}

\section{Without Remedy: Lessons Learned from a Gendered Analysis of the 2018 Hungarian General Elections}

\author{
ANDREA PETŐ
}

One could ask: What was that feminist colleague thinking when she announced in 2018 that she wanted to join a new Facebook group, called "Feminism of the Hungarian Sociological Association" (FHSA)? The new group included two administrators whom that same self-declared feminist scholar had previously 'blocked' as friends. This was the question that the group administrators FHSA actually asked themselves, when that ostensibly fierce, fearless and dedicated feminist activist submitted her request to join the new site - after she had already played a key role in trolling and destroying the oldest, most visited professional Facebook page called "Gender Studies in Hungary". The latter group had served as the most important infrastructure for feminist activism and teaching in recent years when public space and funding began shrinking considerably. In 2017, the Hungarian community of scholars and activists were shaken by several events that were long in coming, which pointed at serious political challenges that feminist politics now face.

At first glance, the inner turmoil witnessed in virtual space around who could ban and exclude whom from a closed, professional Facebook group may have had nothing to do with the results of three consecutive elections in Hungary. The Fidesz Magyar Polgári Szövetség (FIDESZ) party, in coalition with the Christian Democratic Party (Kereszténydemokrata Néppárt/KDNP), won all three, starting in 2010. In 2018, they increased their electoral support by an additional 440.000 votes. Significantly, this victory occurred even though the FIDESZ-KDNP government has been under international pressure for dismantling the rule of law, undermining the freedom of press, restricting women's rights, and mismanaging European Union (EU) funds, among other concerns (Petö 2017a). The government was nonetheless able to use the critique it encountered received abroad to its own advantage in the domestic arena where votes matter. These parties utilized external criticisms to justify an intensification of government rhetoric, claiming that Brussels, migrants and György Soros have waged a war against Hungary while illegitimately interfering in its domestic affairs. While opposition activists gave interviews to the foreign press, participated in hearings and attended informal dinners abroad, FIDESZ used government funding to mobilize voters in the countryside, often by distributing campaign donations or pressuring citizens to vote for its incumbents. In contrast to mainstream views, I argue that it is crucial to examine the strategies behind FIDESZ's consecutive victo- 
ries and to trace their connection with the virtual hurricane that destroyed the oldest, largest Hungarian-speaking Facebook group of gender scholars and activists. What does the collapse of the only professional gender studies Facebook venue tell us about the situation and limitations of feminist politics in Hungary, at a time when such politics are desperately needed? Feminists fought their battles on Facebook, using the weapons of unfriending, exclusion, and blocking. For many, the virtual closed space turned into a substitute for real, face-to face debates and political activism on the ground. This battle came to symbolize the same political crisis that led to FIDESZ's third electoral victory.

\section{The Illiberal Polypore State}

The current predicament of progressive politics, and that, the crisis of feminist political activism, can be traced back to multiple factors. This article discusses only one of them - new state formation and the novel quality of governance that the FIDESZ-KDNP has established in recent years. Political scientists are still arguing over whether the current ruling system should be characterized as "democratic authoritarianism," the "illiberal state," or as a "mafia state". Together with the Polish sociologist Weronika Grzebalska I have suggested applying the term "polypore state" (Grzebalska/Petö 2016).

The polypore is a parasitic pore fungus that lives on wood and produces nothing but further polypores. Our article defined three functional characteristics of the polypore state, all of which are gendered (ibd.; Grzebalska/Petö 2018). First, these characteristics are weakly represented or else are missing from traditional political analyses, much less considered in the opposition's electoral strategies. Still, all three are of key importance in understanding FIDESZ's third electoral victory, following a campaign during which the opposition could barely reach voters outside of Budapest; nor did their messages respond to the electorate's everyday problems. Secondly, they help to explain the reasons behind the desperate activities typical of Hungarian opposition politics today, exemplified by virtual actions, such as interviews and Facebook posts. Third, they aid us in comprehending why the opposition remain incapable of processing the real reasons behind their electoral defeat; instead they resort to blaming misled and manipulated voters. The self-destructive, virtual fights among Hungarian feminists on Facebook offers but one sign of this predicament.

One crucial feature of the polypore state involves the establishment of a parallel, state-financed sphere of non-governmental organizations (NGOs). The polypore state finances NGOs that appear to have the same or similar goals as the other human rights organizations that have been established since the regime change that took place after 1989 that concentrated on: the gender-equal balancing of family and work, the reintegration of mothers into the job market, assistance for mothers with small children. However, the ideological framing now is entirely different. To receive government financial support, these NGOs must display unfailingly loyalty 
both to the government and to the patriarchal system it represents. In other words, they cannot challenge either the patriarchal political system, its institutions or its agents. As a result, the Hungarian government can present a busy, flourishing NGO sphere to the fact-finding members of the European Parliament, or to the UN Committee on the Elimination of Discrimination against Women (CEDAW Committee; EP/Noichl 2018); in the meantime, monetary sources have completely dried up for all but a few, „non-loyal” NGOs and activists. For NGO-ized Hungarian feminists who have lived from project to project, this move amounts to a death blow: Their livelihoods have been wiped out, and entire offices have been shut down. Literally, „spaces” for NGOs that are not loyal to the state have ceased to exist. The expertise and networks that required decades to build have gradually lost their social and cultural value, as poverty increases, and markets shrink, ultimately leading to brutal fights and fierce competition in the virtual domain.

Another characteristic of the polypore state involves familism, or the replacement of gender politics with family politics, based on a normative model limited exclusively to heterosexual married couples, who are supported by state social policies. The vocabulary, agenda, action plans and international networks born of Hungarian women's movements are all embedded in the discourse of women's universal rights. The rhetoric of familism took off from a women's rights framework but replaced women with the family as its key focus. Women are present as caregivers: wives, mothers and, at best, as part-time workers. For feminists used to working within a human rights framework, this was an unexpected turn for which they were illprepared. It took them by surprise when government measures, such as access to childcare assistance for the employed in 2014, which had significantly increased the number of working mothers with small children, became widely popular. The family tax and the flat-rate tax in 2011 are also popular, even though volumes of expert analysis prove that the first is disadvantageous for women, while the latter only favours high income families (Szikra 2014). The fact that voters are opting for measures that work against their own economic interests and supporting a party which impoverishes them further is a new phenomenon. This, in and of itself, calls for a more complex analysis of voter motivations. A further challenge for feminist politics is to communicate such policy consequences in an interesting, comprehensive manner at a time when the ideological and physical spaces are dominated by the polypore state. So far, we have no solutions for these challenges. Government propaganda has deliberately undermined the social and symbolic legitimation of Gender Studies and the activist work carried out by NGOs; this has only exacerbated the panic and bitterness felt among those involved, sparking additional, venomous Facebook debates.

This leads us to consider the third characteristic of the polypore state, namely, its utilization of security discourse. The FIDESZ government regularly presents policyrelated questions as national security issues. According to this rhetoric, the vigilant government is working to defeat the threats posed by Brussels, the migrants, György Soros etc. According to government propaganda, NGOs, especially women's rights 
organizations are likewise threatening, subverting the traditional family model, using foreign money and following foreign orders. The feminist activists who attempt to counter this discourse start from a very disadvantaged position. On the one hand, government arguments are irrational, as illustrated by the fact that the number of persons officially seeking asylum in Hungary was and remains negligible. Yet, the government succeeded in introducing an emotional turn which has made the application of rational arguments impossible. On the other hand, use of security discourse has sabotaged the legitimacy of the earlier, all-encompassing human rights discourse. This marked a first perceptible shift in policy away from scientific knowledge, once the government started to use Gender Studies as an instrument for fear-mongering. State official applied the toolkit of science, by citing a hodgepodge of surveys in an ad hoc manner, which allowed them to undermine the relevance of gender research, their empirical findings, as well as the value and legitimacy of their scientific endeavours in general. Another example involves the attack on academic freedom by way of the Lex CEU (Central European University); in spring 2017 the Hungarian Parliament amended the Higher Educational Law targeting the CEU on two levels. First, it requires that the CEU must have a corresponding US campus, something it has never had in its twentysix-year history; it further required that this campus be up and operating by January 1,2018 . Second, the bill demanded that hosting government sign a written agreement with the home-country government of any foreign university in Hungary. The US campus is operational as of this point, but the FIDESZ government failed to sign the agreement with the State of New York, where CEU is chartered. This was followed by the attack against the Hungarian Academy of Sciences, after FIDESZ's 2018 landslide victory allowed it to take direct state control of its budget (Pető 2017b).

\section{The Anti-Gender Movement and the Establisment of a New World Order}

Is there a perceptible difference in worldview between Gender Studies and the antigender movement, parallel to that between conservative and liberal political philosophies? Or does their relationship sooner resemble the one between creationism and evolutionary biology, in which the latter considers the former mock science, which the expert community needs to combat with all of its scientific might? Because Gender Studies is a revisionist science, emphasizing the importance of assessing who speaks from what position (as opposed to absolute scientific objectivity) and following a value-based revisionism (Tucker 2008). Gender Studies therefore cannot counter the pressure of the anti-gender equality movement by claiming that the latter is "unscientific" or "nonobjective". In other words, there is a re-visioning science built on the results of revisions, on one side, and, on the other, a science which itself is "re-visioning", and therefore highly vulnerable, since its own legitimacy is at stake. It has been a long road from Max Weber's famous Wissenschaft als Beruf (Weber 1917/2017) to the institutionalization of Gender Studies. Scientific findings are continuously revisited and updated, revised, of course, but its re-evaluation is not 
acceptable. The anti-gender movement utilises pseudo-scientific arguments to support its ideological aims, but what makes it into a mock science is the way in which it does so. The language is saturated with hatred, the kind of hatred that the members of the Gender Studies Facebook group internalized and then turned against each other.

\section{Conclusion}

The anti-gender movement is not merely another offshoot of age-old anti-feminist backlash. When modern politicians like Orban, Erdogan and others claim that women's sole purpose is child-bearing, or when a pop celebrity who should remain nameless in this article discusses the so-called "female principle", meaning essentialised "womanhood" these are not simply conservative responses to the success of the second-wave feminist movements. The anti-gender movement is a fundamentally new phenomenon that was launched for the sake of establishing a new world order and not a backlash as it will create a fundamentally new context (Grzebalska 2016; Hark/Villa 2015; Petö 2015a, 2015b). It is a hegemonic fight for socialization in the Gramscian sense (Petö 2017c). The anti-gender movement stands as a nationalist, neoconservative response to the crisis induced by the global, neoliberal world order. It should therefore mobilize all people committed to human rights and democracy, and not only gender researchers (Grzebalska 2016; Kováts/Pető 2017). The anti-gender movement attacks liberalism and thus democracy, insofar as liberalism and democracy have been intertwined since the Enlightenment. In the meantime, the role of the state is changing, because the polypore state no longer considers diversity an asset anymore and moves from the alibi like compliance with EU diversity adopted for EU accession (Pető 2017d).

The opposition has yet to find any remedy against the functional characteristics of the polypore state, relying on the creation of a parallel NGO sphere, familism and the securitization of many issues not only migration but from food safety to education. This is partly because activists did not notice that all these processes are gendered, and that gender is the "symbolic glue" that connects and mobilizes political powers which had previously not seemed reconcilable; it also owes partly to their failure to match their political vocabulary to actual social problems (Grzebalska/Kováts/Pető 2017). Alhough the Sargentini-draft report for the European Parliament about the rule of law in Hungary talks about a dismantling of the rule of law and government interference in media, the voters are more concerned with everyday financial problems and the crisis of care (European Parliament/Sargentini 2018).

Feminist politics should reconsider the reasons and the consequences of not having been part of mainstream progressive politics since the collapse of communism; feminists must learn to respond to real social problems in an accessible language. It is only then that we can hope that future Facebook debates will not shatter Hungarian community of gender researchers and activists, and that a social media network like the FHSA would grow to encompass more than its current seven hundred members. The feminist activist who submitted this request to join the new Facebook group, 
which might be the first step in a much-needed process of self-reflection. Lastly and most importantly, perhaps then our debates would not use the register and vocabulary of the FIDESZ-created hate rhetoric any more. This would be the first step toward avoiding the publication of an article explaining Orban's fourth nationalpopulist victory in this journal in 2022.

\section{References}

CEDAW Committee: Country reports - the United Nations. Internet: www.un.org/womenwatch/ daw/cedaw/reports.htm (27.7.2018).

European Parliament/Sargentini, Judith, 2018: Draft Report on a Proposal Calling on the Council to Determine, pursuant to Article 7(1) of the Treaty on European Union, the Existence of a Clear Risk of a Serious Breach by Hungary of the Values on which the Union is founded (2017/2131(INL)). Committee on Civil Liberties, Justice and Home Affairs, 11.4.2018. Internet: www.europarl.europa.eu/resources/library/media/20180411RES01553/20180411RES01553.pdf (27.7.2018).

European Parliament/Noichl, Maria, 2018: Draft Opinion of the Committee on Women's Rights and Gender Equality for the Committee on Civil Liberties, Justice and Home Affairs on the Situation in Hungary (pursuant to the European Parliament Resolution of 17 May 2017) (2017/2131(INL)), 8.3.2018. Internet: www.europarl.europa.eu/sides/getDoc.do?type=COMPARL\&reference=PE619.174\&format=PDF\&language=EN\&secondRef=01 (27.7.2018).

Grzebalska, Weronika, 2016: Why the War on "Gender Ideology" Matters - and not Just to Feminists. Anti-Genderism and the Crisis of Neoliberal Democracy. In: Visegrad Insight, 7.3.2016. Internet: http://visegradinsight.eu/why-the-war-on-gender-ideology-matters-and-not-just-tofeminists/ (27.7.2018).

Grzebalska, Weronika/Kováts, Eszter/Pető, Andrea, 2017: Gender as Symbolic Glue: How “Gender" became an Umbrella Term for the Rejection of the (Neo)liberal Order. In: Political Critique, 13.1.2017. Internet: http://politicalcritique.org/long-read/2017/gender-as-symbolic-glue-howgender-became-an-umbrella-term-for-the-rejection-of-the-neoliberal-order/ (27.7.2018).

Grzebalska, Weronika/Pető, Andrea, 2016: How Hungary and Poland have Silenced Women and Stifled Human Rights. In: The Huffington Post, 16.10.2016. Internet: https://www. huffingtonpost. com/the-conversation-global/how-hungary-and-poland-ha_b_12486148.html?guccounter=1 (27.7.2018).

Grzebalska, Weronika/Pető, Andrea, 2018: The Gendered Modus Operandi of the Illiberal Transformation in Hungary and Poland. In: Women's Studies International Forum. 68, 164-172.

Hark, Sabine/Villa, Paula-Irene (Eds.), 2015: (Anti-)Genderismus. Sexualität und Geschlecht als Schauplätze aktueller politischer Auseinandersetzungen. Bielefeld.

Kováts, Eszter/Pető, Andrea, 2017: Anti-Gender Discourse in Hungary: A Discourse without a Movement? In: Kuhar, Roman/Paternotte, David (Eds.): Anti-Gender Campaigns in Europe: Mobilizing against Equality. Lanham et al., 117-133.

Pető, Andrea, 2015a: "Anti-Gender" Mobilisational Discourse of Conservative and Far Right Parties as a Challenge for Progressive Politics. In: Kováts, Eszter/Poim, Mari (Eds.): Gender as Symbolic Glue. The Position and Role of Conservative and Far Right Parties in the Anti-Gender Mobilizations in Europe. Foundation for European Progressive Studies and Friedrich-Ebert-Stiftung, 126-132. Internet: http://library.fes.de/pdf-files/bueros/budapest/11382.pdf (27.7.2018).

Pető, Andrea, 2015b: Gender Equality as Re-Enchantment: Political Mobilisation in Times of "Neo-Patriarchal Neoliberalism" and Possibilities of Bipartisan Dialogue. In: Woman Up! 2. A Transatlantic Dialogue. Foundation for European Progressive Studies. Brussels, 139-145.

Pető, Andrea, 2017a: Hungary’s Illiberal Polypore State. In: European Politics and Society Newsletter. (21), 18-21. 
Petö, Andrea, 2017b: Report from the Trenches. The Debate around Teaching Gender Studies in Hungary. Internet: www.boell.de/en/2017/04/10/report-trenches-debate-around-teachinggender-studies-hungary (27.7.2018).

Pető, Andrea, 2017c: How are Anti-Gender Movements Changing Gender Studies as a Profession? In: Religion and Gender. 6 (2), 297-299. Internet: www.religionandgender.org/articles/abstract/10.18352/rg.10182/ (27.7.2018).

Pető, Andrea, 2017d: From Women through Gender to Unconscious Bias: Changing Terminology about Gender Equality in the EU. In: Kovats, Eszter (Ed.): The Future of the European Union Feminist Perspectives from East-Central Europe. Budapest: FES, 21-27. Internet: http://library.fes.de/ pdf-files/bueros/budapest/14210.pdf (27.7.2018).

Szikra, Dorottya, 2014: Democracy and Welfare in Hard Times: The Social Policy of the Orbán Government in Hungary between 2010 and 2014. In: Journal of European Social Policy. 24 (5), 486-500.

Tucker, Aviezer, 2008: Historiographic Revision and Revisionism. In: Kopecek, Michal (Ed.): Past in Making. Historical Revisionism in Central Europe. Budapest, 1-15.

Weber, Max, 1917/2017: Wissenschaft als Beruf. Berlin.

\title{
„Gender Studies“ in Ungarn in Gefahr
}

Die ungarische Regierung plant mit dem Dekret 42294/2018 Gender-Studies an der privaten Zentraleuropäischen Universität (CEU) und der größten staatlichen Eötvös Lorand Universität (ELTE) abzuschaffen. Das Verbot ist Teil jener politischen Maßnahmen, die in dem Beitrag von Andrea Pető angesprochen werden und mit denen massiv in die akademische Freiheit eingegriffen wird. Zahlreiche Verbände auf europäischer Ebene ebenso wie auch in den verschiedenen Ländern haben gegen dieses Vorhaben protestiert. Auf unserer Facebook-Seite https://www.facebook.com/FeminaPolitica werden die aktuellen Entwicklungen dokumentiert. Dort finden sich auch Links zu verschiedenen Protestbriefen und Petitionen.

\section{Gewalt an Frauen auf der Flucht}

\author{
JASMIN KASSAI. HANNA LICHTENBERGER
}

Laut aktuellen Schätzungen des Hohen Kommissars der Vereinten Nationen für Menschenrechte (United Nations High Commissioner for Human Rights/UNHCR) waren bis Ende 2017 68,5 Millionen Menschen auf der Flucht, gut die Hälfte davon sind Frauen (UNHCR 2018, 56). Frauen fliehen wie Männer auch auf Grund von Menschenrechtsverletzungen, Krieg, Armut, Folter, staatlicher Repression. Hinzu kommen aber auch geschlechtsspezifische Fluchtgründe, wie unter anderem weib- 
liche Genitalverstümmelung, Zwangsverheiratung, Zwangsprostitution, restriktive geschlechtsspezifische Gesetze (zum Beispiel Arbeits- oder Bildungsverbote), Gewalt in der Familie und Vergewaltigung. Letztere wird auch systematisch als Kriegsmittel zur Drohung und/oder Bestrafung von Frauen, die verdächtigt werden der Opposition anzugehören, eingesetzt (Referat für Frauen und Gleichstellung des Amtes der Vorarlberger Landesregierung 2016, 5).

Diejenigen Frauen, die es schaffen, den beschwerlichen Weg der Flucht in der Hoffnung auf ein Leben in Sicherheit anzutreten, sind häufig während oder nach der Flucht geschlechtsspezifischer Gewalt ausgesetzt. Im Folgenden sollen einige Schlaglichter auf Formen geschlechtsspezifischer Gewalt geworfen werden. In einem ersten Schritt werden geschlechtsspezifische Gefahren während der Flucht aufgezeigt. Daran anschließend thematisieren wir Formen geschlechtsspezifischer Gewalt in Geflüchtetenlagern. Abschließend werden Aspekte institutionalisierter geschlechtsspezifischer Gewalt in Asylverfahren beleuchtet. ${ }^{1}$

\section{Geschlechtsspezifische Gewalt auf der Flucht}

Zwar gibt es bisher keine aussagekräftigen Daten über das Ausmaß der geschlechtsspezifischen Gewalt, der Frauen und Mädchen auf der Flucht ausgesetzt sind, Anhaltspunkte liefert jedoch eine in Deutschland und Norwegen durchgeführte kleine Befragung von Amnesty International (Amnesty International 2016). In dieser wurden 40 Berichte von Frauen und Mädchen, die von der Türkei nach Griechenland und dann über die Balkanroute geflohen und im Norden Europas angekommen waren, veröffentlicht. Die Befragung bringt zum Ausdruck, dass sich alle Befragten über die gesamte Fluchtroute hinweg unsicher und bedroht fühlten. Besonders alleinreisende Frauen und jene, die nur mit ihren Kindern reisten, waren Gewalt ausgesetzt - v.a. in den Transitgebieten ${ }^{2}$ und Flüchtlingslagern in Ungarn, Kroatien und Griechenland. Einige Frauen berichteten, dass sie gezwungen waren, in Lagern neben anderen männlichen Geflüchteten zu übernachten, sodass manche es bevorzugten, an öffentlichen Stränden ohne Überdachung zu nächtigen, um sexualisierten Übergriffen zu entgehen. Sieben der interviewten Frauen waren zum Zeitpunkt der Flucht schwanger und erzählten von Missständen in der medizinischen Versorgung, dem Fehlen von einfachen Nahrungsmitteln sowie körperlichen Übergriffen. Zwölf der Befragten gaben an, sexualisierte Übergriffe in europäischen Transitlagern erlebt zu haben.

\section{Geschlechtsspezifische Gewalt in Geflüchtetenlagern}

Geflüchtetenlager weisen ebenso geschlechtsspezifische Risiken auf, nicht zuletzt, da die besondere Verletzungsoffenheit von Frauen schlicht nicht berücksichtigt wird. So gibt es laut Amnesty International in keinem der lybischen Lager weibliche Wachposten. Außerdem fehlen Amnesty International zufolge beispielsweise 
in europäischen Camps, u.a. auch in einem großen deutschen Erstaufnahmezentrum, geschlechtergetrennte Duschmöglichkeiten (ebd.). Laut eines weiteren Berichts von Amnesty International sind Migrantinnen und Frauen auf der Flucht in libyschen Immigrations-Gefangenenlagern, die in der Verantwortung des Innenministeriums liegen, sexualisierter Gewalt sowie auch anderen Formen von Folter, Sexsklaverei und Misshandlung ausgesetzt. Das Kinderhilfswerk der Vereinten Nationen (United Nations International Children's Emergency Fund/UNICEF) berichtet, dass die Hälfte aller Frauen und Kinder von sexuellem Missbrauch erzählten. In einer Befragung von Kindern und Frauen in Libyen, die das UNO Kinderhilfswerk 2016 durchgeführt hat, gaben drei Viertel der Kinder an, Gewalt seitens Erwachsener erlebt zu haben; viele erzählten außerdem, dass sie finanzieller Erpressung seitens der (häufig männlichen) Schlepper ausgesetzt waren (UNICEF 2017, 2f.). Ohnehin sind die Kosten für die Flucht sehr hoch: Zwischen 200 und 1.200 US-Dollar mussten die Befragten den Schleppern zahlen, oft erhöht sich der Betrag nach Ankunft in Europa. Alleinreisende Frauen auf der Flucht kommen häufig aus sozioökonomisch schlechteren Verhältnissen als Männer und sind unter anderem auch deshalb eine besonders vulnerable Personengruppe (Worbs/Baraulina 2017). Es gibt Berichte über Schmuggler, die Frauen zu sexuellen Handlungen genötigt haben. Frauen werden auf Grund ihrer mangelnden finanziellen Ressourcen dazu gezwungen, diese auszuführen, um ihre eigene Weiterreise zu sichern oder die ihrer Kinder bzw. ihrer Familie nicht zu gefährden. Es existieren Berichte über junge Mädchen, die monatelang oder sogar Jahre in Besitz eines Schleppers waren, um ihre Reise abzuarbeiten (UNICEF 2017, 2f.).

\section{Institutionelle Gewalt in Asylverfahren}

Auch nach der Ankunft in einem sicheren (europäischen) Land sind Frauen im Asylwesen struktureller Gewalt ausgesetzt. Dies liegt erstens daran, dass auf Grundlage der Genfer Flüchtlingskonvention (1951) sexualisierte Gewalt nicht als Fluchtgrund anerkannt wird. Sie bietet lediglich jenen Personen Schutz, die auf Grund von „Rasse ${ }^{3}$ (sic!), Religion, Nationalität, Zugehörigkeit zu einer bestimmten sozialen Gruppe oder wegen politischer Überzeugung" (ebd.) von staatlicher Seite verfolgt werden - Geschlecht als Fluchtgrund findet keine Erwähnung. Fluchtgründe, die nur Frauen betreffen, können somit gemäß der Genfer Flüchtlingskonvention nur unter der sozialen Gruppe oder der politischen Überzeugung subsumiert werden. Dadurch ergibt sich ein gewisser Spielraum für behördliche Willkür. Sarah Ortner (2016) zeigt am Beispiel der österreichischen Asylverfahren, dass folglich insbesondere in erster Instanz angenommen wird, „dass sexuelle Gewalttaten durch Staatsorgane einer Frau von Einzelpersonen angetan würden und deshalb keine staatliche Verfolgung darstellten. Gravierende Frauenrechtsverletzungen im häuslichen Bereich seien private Bedrohungen und daher asylrechtlich nicht relevant“"(ebd., 2). 
Eine zweite wesentliche Hürde für geflüchtete Frauen ist der Erstkontakt mit europäischen Behörden. Bei Eingriffen in die sexuelle Selbstbestimmung gelten europaweit grundsätzlich Asylverfahrensrichtlinien, die besagen, dass Betroffene von einem_r gleichgeschlechtlichen Person, sofern nicht anders gewünscht, vernommen werden müssen. Die 2013 verabschiedete Richtlinie des Europäischen Parlaments und des Rates zu gemeinsamen Verfahren für die Zuerkennung und Aberkennung des internationalen Schutzes (2013) sieht somit vor, in der Zulassung zu Verfahren und den Verfahren Geschlecht zu berücksichtigen, nicht aber Geschlecht als Fluchtgrund anzuerkennen. Die Richtlinie verweist darauf, dass ,,(b)estimmte Antragsteller (...) unter Umständen besondere Verfahrensgarantien (benötigen), unter anderem aufgrund ihres Alters, ihres Geschlechts, ihrer sexuellen Ausrichtung, ihrer Geschlechtsidentität, einer Behinderung, einer schweren Erkrankung, einer psychischen Störung oder infolge von Folter, Vergewaltigung oder sonstigen schweren Formen psychischer, physischer oder sexueller Gewalt. Die Mitgliedstaaten sollten bestrebt sein, Antragsteller, die besondere Verfahrensgarantien benötigen, als solche zu erkennen, bevor eine erstinstanzliche Entscheidung ergeht" (Richtlinie des Europäischen Parlaments und des Rates 2013, 62). In der Praxis gibt es mit dieser Regelung jedoch viele Probleme. Frauen werden bei der Erstbefragung meist nicht einmal über dieses Recht informiert. Erschwerend kommt hinzu, dass Frauen auf nicht sensibilisierte und psychologisch ungeschulte Beamt_innen treffen und nicht das nötige Vertrauen aufbauen können, um über geschlechtsspezifische Fluchthintergründe zu erzählen. Wenn überhaupt, werden frauenspezifische Fluchtursachen deshalb meist sehr spät oder gar nicht im Asylverfahren eingebracht und können daher nicht berücksichtigt werden.

\section{Was es braucht}

Was bräuchte es, um geschlechtsspezifische Verletzungsoffenheit auf der Flucht und während Asylverfahren zumindest zu minimieren? Entgegen der derzeitigen europäischen Tendenz, die ,Festung Europa ${ }^{\prime}$ zu stärken, müssten internationale Fluchtrouten gesichert und legal zugänglich gemacht werden, um Übergriffen und Ausbeutung von Frauen auf der Flucht entgegenzuwirken. Frauen- bzw. geschlechtsspezifische Fluchtgründe müssten auch in der Praxis der Rechtsprechung anerkannt werden. Dazu fehlen bisher Zahlen, weil Statistiken nicht geführt werden. Um institutionelle Gewalt zu verhindern, bräuchte es zudem mehr Schulungen und Sensibilisierungsarbeit an im Asylverfahren involvierten Beamt_innen und Sicherheitspersonal. Nach der Ankunft müssten in Erstaufnahmezentren und Asylunterkünften geschützte Orte für Frauen und Kinder sowie LGBTIQ-Personen vorhanden sein, um etwaigen Übergriffen vorzubeugen. Vor dem Hintergrund, dass geflüchtete Frauen häufig an einer sogenannten posttraumatischen Belastungsstörung leiden, bedarf es dringend des Ausbaus von öffentlich-finanzierten Psychotherapieplätzen mit Fokus auf transkultureller und Trauma-spezifischer Arbeit. Ebenso wichtig wäre der Zugang zum ös- 
terreichischen Arbeitsmarkt, um Frauen gesellschaftliche Teilhabe zu ermöglichen. Bisher sind die Zugangsregelungen für Frauen im Asylverfahren sehr restriktiv und de facto nicht gegeben, sodass vielen geflüchteten Frauen nur eine Möglichkeit der legalen Erwerbstätigkeit bleibt, die Sexarbeit. Die Öffnung des Arbeitsmarktes für Frauen im Asylverfahren würde zumindest ein gewisses Maß an Wahlfreiheit eröffnen und darüber hinaus zur Ermöglichung gesellschaftlicher Teilhabe beitragen. Die aktuelle Politik der österreichischen Bundesregierung besteht darin, rechtspopulistische Akteur_innen in Europa zusammenzubringen, um weitere Schikanen gegen Flüchtende auszuarbeiten. So wie alle Formen rechter Politiken braucht die österreichische Regierung die rassistische, angstschürende Dauerdebatte und die Inszenierung des Ausnahmezustandes auch, um von tiefgreifenden Angriffen auf Frauen(schutz) organisationen, Arbeitnehmer_innen, Kinder und Jugendliche abzulenken. So bleibt $\mathrm{zu}$ befürchten, dass sich die Verletzungsoffenheit von Frauen auf der Flucht weiter verstärkt, obwohl die Maßnahmen dagegen auf dem Tisch liegen würden.

\section{Anmerkungen}

1 LGBTIQ-Personen sind sowohl in den Herkunftsländern, in denen Homosexualität kriminalisiert wird, auf der Flucht sowie im Behördenkontakt besonderer Vulnerabilität ausgesetzt, worauf von Beratungsstellen und Interessenverbänden verstärkt verwiesen wird (vgl. dazu Der Standard 2018; Malmoe 2018).

2 Transitgebiete sind sowohl jene Transitzonen, die Ungarn 2015 an Flughäfen errichtet hat, wie umzäunte und abgeschlossene Geflüchtetenlager, die an den Landesgrenzen errichtet wurden. Transitlager sind aber auch Lager an südeuropäischen Landesgrenzen, wie etwa im nordgriechischen Idomeni, wo Geflüchtete darauf warten müssen, die Grenze zum Nachbarland Mazedonien, das nicht zur Europäischen Union gehört und somit auch nicht dem Schengen-Abkommen unterliegt, zu überqueren.

3 Zu Kritik und Begriffsgeschichte des „Rasse“-Begriffes im Recht vgl. Cremer 2018

\section{Literatur}

Amnesty International, 2016: Sexualisierte Gewalt gegen weibliche Flüchtlinge. Internet: www.amnesty.de/2016/1/18/sexualisierte-gewalt-gegen-weibliche-fluechtlinge?destination =node $\% 2 F 668$ (1.7.2018).

Cremer, Hendrik, 2018: Zur Problematik des Begriffs „Rasse“ in der Gesetzgebung. In: HeinrichBöll-Stiftung (Hg.): Heimatkunde. Migrationspolitisches Portal. Internet: https://heimatkunde. boell.de/2008/11/18/zur-problematik-des-begriffs-rasse-der-gesetzgebung (6.8.2018).

Der Standard, 2018: Eine Frage von Leben und Tod für LGBT-Flüchtlinge. Internet: http://derstandard.at/2000076478359/Eine-Frage-von-Leben-und-Tod-fuer-LGBT-Fluechtlinge (1.7.2018).

Genfer Flüchtlingskonvention (GFK), 1951: Abkommen über die Rechtsstellung der Flüchtlinge (GFK). Internet: www.ris.bka.gv.at/GeltendeFassung.wxe?Abfrage=Bundesnormen\&Gesetzesnu mmer $=10005235$ (1.7.2018).

Malmoe, 2018: Was? Du bist nicht auf Gay-Romeo? LGBTQ-Flüchtlinge und die österreichischen Asylbehörden. Internet: https://malmoe.org/artikel/alltag/3407 (18.7.2018).

Ortner, Sarah, 2016: Frauen auf der Flucht. Jahoda-Bauer Institut. Policy Brief 02/2016. Internet: http://jbi.or.at/wp-content/uploads/2016/03/perspektiven_2_2016_frauen-und-flucht.pdf (1.7.2018). 
Referat für Frauen und Gleichstellung des Amtes der Vorarlberger Landesregierung, 2016: frauen auf der flucht. vom gehenmüssen und ankommenwollen. Internet: https://www.vorarlberg.at/pdf/if_faktum02_16_vorarlberg.pdf (1.7.2018).

Richtlinie des Europäischen Parlaments und des Rates vom 26. Juni 2013 zu gemeinsamen Verfahren für die Zuerkennung und Aberkennung des internationalen Schutzes (Neufassung) (2013/ 32/EU). Internet: www.easo.europa.eu/sites/default/files/public/procedures-DE.pdf (30.7.2018).

UNHCR, 2018: Global Trends. Forced Displacement in 2017. Internet: www.unhcr.org/dach/wpcontent/uploads/sites/27/2018/06/GlobalTrends2017.pdf (1.7.2018).

UNICEF, 2017: A Deadly Journey for Children. The Central Mediterranean Migration Route. Internet: www.unicef.de/blob/135970/6178f12582223da6980ee1974a772c14/a-deadl-journey-forchildren---unicef-report-data.pdf (1.7.2018).

Worbs, Susanne/Baraulina, Tatjana, 2017: Geflüchtete Frauen in Deutschland: Sprache, Bildung und Arbeitsmarkt. Internet: www.bamf.de/SharedDocs/Anlagen/DE/Publikationen/Kurzanalysen/kurzanalyse7_gefluchetete-frauen.pdf (30.7.2018).

\section{Afrin, Frauenrevolution und die Jineolojî}

\section{MECHTHILD EXO}

Vor sechs Jahren, am 19. Juli 2012, fand in Nordsyrien der Anfang einer Revolution in dem Gebiet statt, das auch als Westkurdistan - kurdisch: Rojava - bezeichnet wird. Die Initiative ging von langjährig bestehenden klandestinen kurdischen Strukturen, nicht zuletzt der Frauenorganisierung, aus und wurde von den seit 2011 unter den Bedingungen der in anderen Orten Syriens entbrannten Aufstände und Repressionen gegründeten Selbstverteidigungskräfte (Yekitiya Xwe Parastina Gel, YXG, später Yekîneyên Parastina Gel, YPG) unterstützt. Staatliche Einrichtungen, die bis dahin unter der Kontrolle des syrischen Baath-Regimes standen, wurden weitgehend unblutig übernommen. Bereits seit 2011 gab es Demonstrationen, meist angeführt von kurdischen Frauenorganisationen. Es war die Zeit des Arabischen Frühlings. Seither findet in Nordsyrien ein gesellschaftlicher Neuaufbau statt, der durch kommunale, konsensorientierte Basisdemokratie, Geschlechterbefreiung und Ökologie geprägt ist. Diese Grundideen basieren auf der Philosophie Abdullah Öcalans und bilden über die kolonialen staatlichen Grenzen hinweg verbindende Säulen in der kurdischen Befreiungsbewegung (Öcalan 2017). Der durch diese politischen Ideen getragene gesellschaftsbefreiende Prozess inspiriert und integriert auch die nichtkurdischen Bevölkerungsgruppen in der Region wie Assyrer_innen, Araber_innen, Turkmen_innen und Ezid_innen und weit darüber hinaus. Im Folgenden erläutere ich diese politischen Ideen und deren Verwirklichung unter anderem mit einem neuen Gesellschaftsvertrag, Frauengesetzen und einer selbstverantwortlichen Gesellschaft. Weiter erkläre ich, warum die Jineolojî als neue, antipatriarchale Wissenschaft, die diese Veränderungsprozesse mit neuen gesellschaftlichen Wissensformen 
verbindet, als große Lernchance für feministische Bewegungen in Europa verstanden werden sollte.

\section{Demokratie ohne Staat}

Revolution wird in der auf Öcalan basierenden politischen Philosophie nicht als Staatsmachtübernahme gedacht; überhaupt ist ein eigener Staat, beispielsweise ein kurdischer Staat, nicht das Ziel des Befreiungskampfes. Mit dem Konzept des demokratischen Konföderalismus wird ein Prozess der zunehmenden Demokratisierung und der politischen Selbstverantwortung der Gesellschaften beschritten, der Staaten immer unbedeutender machen soll. Denn Staatlichkeit wird nicht als unumstößliches Ordnungsprinzip gesehen. Ein Staat könne nicht antipatriarchal und an der Selbstbestimmung der verschiedenen sozialen Gruppen eines (Staats-)Gebietes orientiert ausgeformt werden, sondern stehe dem von seinen Grundprinzipien her entgegen. Vorerst bedeutet das, die autonome Selbstorganisierung der verschiedenen gesellschaftlichen Gruppen - religiöse Minderheiten, unterschiedliche kulturelle Gruppen, Jugendliche, Intellektuelle, Künstler_innen, Frauen usw. - zu stärken. Demokratie hat nach diesem Verständnis ihre Basis in überschaubaren, kommunalen Zusammenhängen: im Stadtviertel oder Straßenzug, im Dorf, aber auch beispielsweise an Schulen, an Universitäten und in wirtschaftlichen Kooperativen. Mit imperativem Mandat werden Delegierte in vernetzende und übergreifende Versammlungen, die Räte, geschickt. Diese Ebenen setzen sich immer weiter fort. Die soziale Verbundenheit und das gemeinschaftlich orientierte, fürsorgende Miteinander sind dabei als Werte leitend, die als Kern des Menschseins verstanden werden. Es wird darauf hingearbeitet, diese demokratische, freiheitliche Selbstverwaltung eigenständig zu praktizieren sowie zugleich in der Verfassung der jeweiligen Staaten, in denen diese Prozesse stattfinden, zu verankern. D.h. die Staaten werden tiefgreifend demokratisiert, solange an eine Welt ohne Staaten noch nicht zu denken ist.

\section{Frauenrevolution}

Die Revolution in Rojava ist als Frauenrevolution bekannt geworden. Frauenorganisierung steht im Zentrum der Aufmerksamkeit. Nach Europa ist das mit den Bildern der bewaffneten Kämpferinnen der Frauenverteidigungseinheiten (kurdisch: Yekîneyên Parastina Jin/YPJ) gedrungen. Diese Bilder gingen vor allem 2014 durch alle Medien, als die Stadt Kobanî in monatelangen schweren Auseinandersetzungen vom Islamischen Staat (IS) zurückerobert wurde. Doch was im westlichen Medienhype auf die (Bilder der) YPJ-Kämpferinnen reduziert und entpolitisiert wurde, ist ein radikaler Transformationsprozess, in dem Frauen führende Rollen in allen Bereichen einnehmen: politisch, ökonomisch, philosophisch, sozial, medial, intellektuell etc. Geschlechterbefreiung wird in dieser gesellschaftlichen Neugestaltung als notwendige Grundlage für alle anderen Veränderungsprozesse angesehen. Patriarchale 
Herrschaft wird als grundlegende destruktive und ungerechte Struktur gesehen, die kapitalistischer und staatlicher Herrschaft vorausgeht. „If we want to construe the true meaning of terms such as equality, freedom, democracy and socialism that we so often use, we need to analyse and shatter the ancient web of relations that have been woven around women" (Öcalan 2017, 59). Alle Geschlechter sowie Partnerschaftsund Familienverhältnisse müssen von der patriarchalen Durchsetzung befreit werden. Es wird von einem System der freien Frauen und freien Männer gesprochen. Das ist die Grundlage für eine selbstverantwortliche Gesellschaft.

\section{Gesellschaftsvertrag und Frauenrechte}

Die Revolution wurde durch klandestin bestehende Strukturen der Frauenorganisierung initiiert und hat von Beginn an sowohl die autonome Frauenselbstorganisierung als auch die gerechte Beteiligung von Frauen in allen Entscheidungsgremien und Leitungspositionen (System der Co-Leitung) parallel verankert. Der Ende 2016 verabschiedete neue Gesellschaftsvertrag der Demokratischen Föderation von Nordsyrien ${ }^{1}$ (DFNS) ist historisch der erste von Frauen geschriebene Gesellschaftsvertrag. Frauenrechte werden umfassend abgesichert. Die entsprechenden Gesetze gehen über das hinaus, was in liberalen westlichen Staaten mühsam und gegen Widerstand in Jahrzehnten durch Frauenbewegungen durchgesetzt werden konnte und gegenwärtig gegen ein anti-feministisches Rollback weiter behauptet werden muss. So ist beispielsweise bereits im Gesellschaftsvertrag verankert, dass „,die Reduzierung von Frauen zu Objekten verboten“ ist (DFNS § 11); „Gewalt gegen Frauen, ihre Ausbeutung und Diskriminierung gelten als Verbrechen und werden nach dem Gesetz bestraft" (ebd., $\S 25)$. Die Gesetze legen nicht nur ein Verbot von jeglicher Form von Sexismus und Gewalt gegen Frauen fest, sondern die Pflicht aller, ,gegen herrschende und rückschrittliche Einstellungen anzukämpfen" (Benario 2017a, 25). Im selbstverwalteten Nordsyrien werden Frauenrechte ganz praktisch und in allen Bereichen des Alltags und Familienlebens umgesetzt. „Der Geschlechterkampf findet nicht nur in der politischen Arbeit und im öffentlichen Raum statt, sondern auch in den Familien. Das ist ein Ausdruck des wachsenden Bewusstseins und der Kraft von Frauen, die sie im Zuge der kontinuierlichen Kämpfe und der autonomen Organisierung der Frauenfreiheitsbewegung in Kurdistan entwickelt haben“" (Benario 2017a, 28). Die Verankerung der Frauenrechte wurde mit neuen Gesetzen, wie u.a. für die Erleichterung der Ehescheidung für Frauen, mit begleitenden Kampagnen und mit sozialen Einrichtungen unterstützt. Die geschaffenen Institutionen wie Mala Jin (Häuser der Frauen), die Beratung und Austausch anbieten, 24-Stunden-Notrufe und Schutzräume sind bedeutend für Veränderungen. Dennoch wird die in ihrem Zusammenhalt und der ethisch-politischen Selbstverantwortung gestärkte Gesellschaft als entscheidender angesehen, um gegen Praktiken der Frauenunterdrückung oder häusliche Gewalt in der lokalen Kommune einzuschreiten. In den selbstorganisierten Kommunen können eigenständig verändernde soziale Lösungen gefunden werden. 


\section{Jineolojî}

Die Überwindung patriarchaler Verhältnisse und Denkweisen als Grundlage einer neuen Gesellschaftlichkeit ist verbunden mit dem Aufbau einer neuen Form von (Sozial-)Wissenschaft. Die Jineolojî - Jin bedeutet Frau, aber auch Leben, -logie steht für Wissenschaft - stellt das Leben(-serhaltende) in den Mittelpunkt und wird konsequent antipatriarchal und vom Standpunkt der Frauen entwickelt. Mythologie, Religion, Philosophie und Wissenschaft werden auf Androzentrismen überprüft und ihre Ausrichtung auf die zunehmend tiefergehende Etablierung patriarchaler Lebensverhältnisse abgelehnt. Binäre Denkweisen werden ebenso zurückgewiesen wie die vielen Trennungen und Zerteilungen, die Kontrolle und Ausbeutung ermöglichen: zwischen Natur und Mensch, zwischen Wirtschaft, Politik und Gesellschaft, zwischen privat und öffentlich, zwischen den wissenschaftlichen Disziplinen und vielem mehr. Das Wissen und die Wissenschaft werden mit der Gesellschaft verbunden und insbesondere mit den Frauen. Entgegen dem traditionellen wissenschaftlichen Ideal einer nicht-involvierten, überlegen handelnden Expertin, die ein Objekt objektiv beforscht, ist Forschung in die ethisch-politische Gesellschaft eingebunden. Aus den Fragen, Wünschen und Problemen der Gesellschaft, die Verantwortung für sich selbst und für gemeinsam getragene ethische Werte übernimmt, ergibt sich ein Forschungsauftrag, der wiederum an den Erfahrungen von den Menschen und dem vorhandenen gesellschaftlichen Wissen ansetzt. Jineolojî wird als „Wissenschaft von der und für die Frauenrevolution“ (Benario 2018, 23) gesehen. Als solche setzt sie sich die Erforschung gesellschaftlicher Möglichkeiten zum Ziel, Leben in komplexen, nicht-hierarchischen Verbindungen zwischen verschiedenen Menschen, sozialen, ethnischen und religiösen Gruppen und Gesellschaften sowie auch zu Pflanzen, Tieren und den Naturelementen zu gestalten - und praktiziert dieses Prinzip auch. Das Lebengebende und Lebenserhaltende werden in den Mittelpunkt gerückt. Matriarchatsforschungen und feministische Forschungen werden ausgewertet und mit der Jineolojî weiterentwickelt. „Insbesondere das Sichtbar- und Bewusstmachen der reichen geschichtlichen Ressourcen der lokalen Frauengeschichte und -kultur in den verschiedenen Epochen und Gemeinschaften der Völker Nordsyriens stellen eine wichtige Inspirationsquelle und Bezugspunkte dar" (ebd., 23). Es wurden Jineolojî-Forschungszentren in Afrîn, Dêrîk und Minbic (alle Nordsyrien) sowie in Brüssel aufgebaut. Jineolojî wurde in den Lehrplan der Oberschulen Nordsyriens integriert und im Oktober 2017 begann der erste Studiengang Jineolojî an der Rojava Universität in Qamislo. Es gibt eine Fachzeitschrift Jineolojî und eine internationale Website: www.jineoloji.org. Jineolojî-Konferenzen wurden in Köln (2014), Stockholm (2015), Paris (2016) und Dêrîk (2018) durchgeführt. 


\section{WomenRiseUpForAfrin und Schweigen statt Solidarität}

„(W)ir haben bewiesen und es hat sich gezeigt, dass das System der demokratischen Selbstverwaltung funktioniert", sagte eine arabische Frau auf der Jineolojî-Konferenz im Januar 2018 in Dêrîk (zit.n. ebd., 25). Die selbstorganisierte Gesellschaft der DFNS entwickelte sich in den letzten sechs Jahren trotz des wirtschaftlichen Embargos und der militärischen Angriffe vom IS und der Türkei äußert schnell und erfolgreich. Sie wurde zur Inspiration für Aktivist_innen und soziale Bewegungen weltweit.

Am 20. Januar 2018 begann die Türkei einen völkerrechtswidrigen Angriffskrieg gegen den nordsyrischen, selbstverwalteten Kanton Afrin. Damit wird genau diese demokratische, frauenbefreiende Gesellschaftsalternative angegriffen. Bereits in den ersten Tagen der Luftangriffe wurde der 3.000 Jahre alte Ain Dara Tempel der Göttin Ischtar, ein Symbol matrizentrischer Geschichte der Region, die in einigen Dörfern bis heute weiterlebt, zerbombt. „Wir betrachten es nicht als Zufall, dass der türkische Staat die Geschichte der Frau zum Ziel seiner Angriffe macht. Stattdessen ist es ein weiteres Mittel, die patriarchale Ordnung zu erhalten" (Jineolojî Akademie 2018). Nach der Besetzung Afrins zusammen mit verbündeten islamistischen Milizen wurde ein repressives, islamistisches Regime eingeführt. Seitdem werden Frauen aus dem öffentlichen Leben zurück in die privaten Häuser gedrängt. Gefangen genommene Kämpferinnen werden vergewaltigt, gefoltert und ihre entkleideten Leichname werden öffentlich zur Schau gestellt. Der türkische Staat betrachtet ,gegen Unrecht und Unterdrückung kämpfende Frauen als eine ,terroristische Bedrohung seiner nationalen Interessen ““ (Benario 2018, 27).

Frauen und Frauenorganisationen weltweit solidarisieren sich mit den Frauen in Afrin, neue Kampagnen und Aktionen unter dem Motto WomenRiseUpForAfrin sind entstanden (siehe https://twitter.com/hashtag/womenriseupforafrin). Dennoch: Solidarität wird von vielen auch verweigert. Die Duldung dieses Krieges durch die NATO-Partner- und andere Staaten wird begleitet von einem allgemeinen Schweigen. Mit dem Anspruch überlegener Urteilsfähigkeit werden in deutschsprachigen linken und feministischen Foren mögliche Fehler bei den Revolutionsaktivitäten unterstellt, um sich so Protestäußerungen gegen den Angriffskrieg zu enthalten. Jetzt herrscht der Islamismus in Afrin. Nur wenige Friedensforscher_innen, (Frauen-) Friedensorganisationen wie die Internationale Frauenliga für Frieden und Freiheit (IFFF/WILPF) und andere kritische, internationalistische (Frauen-)Organisationen, unter anderem die feministische Kampagne „Gemeinsam kämpfen“, Terre des Femmes, das Informationsbüro Nicaragua, die Partei Die Frauen, die Frauenkirche Zentralschweiz und einige GEW-Landesverbände, verteidigen bisher mit ihrer Stimme die selbstbestimmte Gesellschaft und die Frauenrevolution in Nordsyrien (http://frauenfuerafrin.blogsport.de). 


\section{Kommunikative Verbindungen schaffen}

Das Selbstverwaltungsgebiet soll zunehmend isoliert werden. Die Kommunikation und direkte Begegnung mit den Menschen, die diesen regionalen Neugestaltungsprozess umsetzen, werden massiv behindert. Das betrifft auch den akademischen Austausch. Die Teilnahme einer akademischen Frauendelegation aus Deutschland, der auch die Autorin angehörte, am Symposium „Die neuen Universitäten und Akademien“, das vom 20. bis 21. Juli 2018 an der 2016 gegründeten Rojava Universität in Qamislo stattfand, wurde verhindert. Die Reise endete auf der irakischen Seite der Grenzstation Semalka. In Übereinstimmung mit dem Auswärtigen Amt Deutschlands (Generalkonsulat Erbil, 16.7.2018, telefonische Auskunft Frau Merks) soll ein Grenzübertritt Richtung Nordsyrien nicht mehr möglich sein. Die Kurdische Regionalregierung (KRG) im Nordirak, die eng mit der türkischen Regierung zusammenarbeitet, verhindert seit Mitte Juli 2018 die Weiterreise - eine Folge der formalen Bestätigung von Recep Tayyip Erdoğan als Präsident der Türkei.

In Nordsyrien wollten die Delegationsteilnehmerinnen die verschiedenen Bereiche und Einrichtungen der Jineolojî-Arbeit kennenlernen und insbesondere mit der Jineolojî-Fakultät der Rojava Universität den Aufbau einer Hochschulkooperation besprechen. Die Grundlagen der Jineolojî werden in Europa, Lateinamerika oder auch Kanada in Seminaren weitergegeben, doch der Ursprung dieser Wissenschaft liegt in der kurdischen Frauenbewegung und in Nordsyrien wird die Jineolojî am intensivsten und praktisch weiterentwickelt. Deshalb hat der Fachbereich Soziale Arbeit und Gesundheit der Hochschule Emden/Leer den Aufbau einer wissenschaftlichen Kooperation mit der Jineolojî Fakultät an der nordsyrischen Rojava Universität beschlossen. Studierende aus Emden sind bereits in den direkten, digitalen Austausch mit der Jineolojî Fakultät in Syrien getreten (Emder Zeitung 9.5.2018). Der Allgemeine Studierendenausschuss (AStA), die Zentrale Gleichstellungsbeauftragte, die Koordinatorin für Nachhaltigkeit und gesellschaftliche Verantwortung der Hochschule sowie auch das Emder Friedensforum haben mit Grußbotschaften ihr Interesse am Austausch und Lernen mit- und voneinander bekundet.

Die akademische Delegationsgruppe konnte sich im Juli 2018 kein eigenes Bild machen und nur eine Vertreterin der Jineolojî-Fakultät persönlich kennenlernen, die dafür nach Erbil, Irak, gereist ist. Das zeigt sehr deutlich, wie wichtig es ist, gute Wege und Bedingungen für den Austausch zu schaffen und die Isolierung voneinander zu überwinden. Zozan Sima, Mitglied der Jineolojî-Akademie Rojava, erklärt: „Wir verfolgen das Ziel, unsere Erfahrungen mit den Frauenbewegungen weltweit zu teilen und mit ihnen auf verschiedenen Ebenen zu kooperieren. Insbesondere glauben wir, dass Frauen, die einen Kampf gegen das System führen, und Frauen, die im Mittleren Osten eine Frauenrevolution zu realisieren versuchen, nur mit Hilfe der Jineolojî tiefgreifende Schritte entwickeln können“ (Sima 2017, 40).

Die Jineolojî-Fakultät strebt die Zusammenarbeit mit Zentren der feministischen und/oder Gender-/Frauenforschung sowie mit Akademiker_innen und Hochschulen 
international an, die nach alternativen Wissenschaftsformen suchen. „Insbesondere suchen wir den Austausch mit Akademikerinnen aus der Frauenforschung; mit feministischen, ökologischen und anarchistischen Akademikerinnen; mit AkademikerInnen, die alternative sozialwissenschaftliche Ansätze gegenüber den positivistischen Sozialwissenschaften verfolgen" (Sima, zit.n. Benario 2017b, 42).

Der Bezug auf die Jineolojî als die Wissenschaft der Frauenrevolution im 21. Jahrhundert bietet die wichtige Möglichkeit, die weit verbreiteten Ambivalenzen zu überwinden, in denen sich feministische und andere kritische Wissenschaft mit den bestehenden akademischen und politischen Verhältnissen arrangiert haben. Stattdessen sollten wir uns mit der wissenschaftlichen Frage beschäftigen, wie wir das Gesellschaftssystem loswerden, das uns zerstört (vgl. Holloway 2015, 14). Die Jineolojî wird bereits von Frauen/Trans/Inter in mehr als elf europäischen Ländern aufgegriffen (Website Jineolojî 2017; Diyar 2018). Die Kooperation mit der JineolojîArbeit in Nordsyrien ist ein solidarischer Schritt gegen die Isolierung und die weiter drohenden Angriffe auf die demokratische Selbstverwaltung. Darüber hinaus - so mein Plädoyer - kann die Jineolojî auch der Weg für feministische Kämpfe und herrschaftskritisches Denken und Handeln in Europa sein.

\section{Anmerkung}

1 Dieser Name wird seit 2016 statt dem kurdischen Wort Rojava benutzt, um der multikulturellen Bevölkerungszusammensetzung gerecht zu werden.

\section{Literatur}

Benario, Andrea, 2017a: Zum Verhältnis von Recht und Moral: Die Dialektik der Frauengesetze in Rojava. In: Kurdistan Report. 190, 24-28.

Benario, Andrea, 2017b: Jineolojî: Von einem Begriff zur Theorie, von der Theorie zur Praxis und bleibenden Strukturen für die Frauenrevolution. In: Kurdistan Report. 194, 36-42.

Benario, Andrea, 2018: Von der Jineolojî-Konferenz zum Widerstand in Efrin. Frauenbefreiung oder patriarchale Barbarei?! In: Kurdistan Report. 196, 23-28.

Demokratische Föderation Nordsyrien (DFNS): Der Gesellschaftsvertrag der Demokratischen Föderation von Nordsyrien. Internet: https://rojname.com/3547324 (28.7.2018).

Diyar, Zilan, 2018: Jineolojî Mediterranean Camp: „We followed the footsteps of Sara in Bilbao“. April 2018. Internet: https://jineoloji.org/en/2018/04/10/jineoloji-mediterranean-camp-we-followed-the-footsteps-of-sara-in-bilbao/ (28.7.2018).

Emder Zeitung, 9.5.2018: „Wie eine Blume in der Wüste." Video-Konferenz der Hochschule Emden/Leer mit Jineolojî Fakultät in Nordsyrien.

Generalkonsulat Erbil der Bundesrepublik Deutschland, 16.7.2018, telefonische Auskunft Frau Merks.

Holloway, John, 2015: Resistance Studies: A Note, A Hope. In: Journal of Resistance Studies. 1 (1), 12-17.

Jineolojî-Akademie, 31.1.2018: Türkische Kampfflugzeuge bombardieren archäologische Stätten in Efrin - Tausende von Jahren alte Zeugnisse der Frauenkultur zerstört. Internet: http:// Jineolojî.org/de/2018/01/31/ (29.7.2018). 
Öcalan, Abdullah, 2017: The Political Thought of Abdullah Öcalan. London.

Sima, Zazan, 2017: Wissenschaft des Lebens - Jineolojî. Jineolojî-Akademie: Bildung und Forschung zur Erweiterung des Freiheitsbegriffs. In: Kurdistan Report. 191, 39-40.

Website Jineolojî, 2017: Bericht über das Jineolojî-Camp 2017. September 2017. Internet: http:// jineoloji.org/de/2017/09/11/bericht-ueber-das-jineoloji-camp-2017/ (28.7.2018). 


\section{NEUES AUS LEHRE UND FORSCHUNG}

\section{Kurznachrichten}

\section{Protest des Netzwerks der Hochschullehrenden gegen Bann der Gender Studies in Ungarn}

Die ungarischen Ministerien für Humanressourcen und für Justiz haben der ungarischen Hochschulrektorenkonferenz einen Gesetzesentwurf zur Abschaffung der Genderstudies vorgestellt. Studierende sollen ihr Studium noch beenden dürfen, zukünftig dürfen Genderprogramme aber nicht mehr angeboten werden. Derzeit haben die ELTE-Fakultät für Sozialwissenschaften und die Central European University (CEU) Genderstudies in ihren Studienprogrammen etabliert.

Der Gesetzesvorschlag reiht sich ein in mehrere Versuche der ungarischen Regierung, Geschlechterforschung und Bildung für politische Ziele in Misskredit zu bringen, da sie dem , ungarischen' Geschlechterideal nicht entsprechen. So wurde etwa vor kurzem das Zentrum für Gesellschaftsforschung der Ungarischen Akademie der Wissenschaften unter Beschuss genommen.

Das Internationale Netzwerk der Hochschullehrenden ruft lokale und internationale Hochschulen und Forschungseinrichtungen zum Protest gegen den Gesetzesvorschlag und die Versuche der ungarischen Regierung, die Freiheit der Hochschullehre einzuschränken und die Stellung der Genderstudies zu diskreditieren, auf.

Die Protestnote kann auf der Seite des Netzwerks der Hochschullehrenden im Wortlaut nachgelesen werden.

Internet: http://oktatoihalozat.hu/wp-content/uploads/2018/08/Call-for-protest.pdf

\section{DFG-Forschungsprojekt „doing family und doing reproduction in vielfältigen Familien“}

Der Vielfalt von Familienbeziehungen und Reproduktionsmodellen widmet sich seit Beginn des Jahres ein neues DFG-Forschungsprojekt an der Humboldt-Universität zu Berlin am Lehrbereich Soziologie der Arbeit und Geschlechterverhältnisse am Institut für Sozialwissenschaften unter Projektleitung von Prof. Dr. Christine Wimbauer, Dr. Almut Peukert und Dr. Mona Motakef (Projektlaufzeit 2018-2020). Die Forschenden untersuchen das Konzept und die Konstruktion von Familien sowie familiale Alltagspraxen. Im Fokus stehen dabei LGBT*Q Familien und ihre Deutung als ,,besondere Familie“. Das Projekt nimmt dazu die von den Familien erlebten gesellschaftlichen Ein- und/oder Ausschlüsse und Ungleichheitserfahrungen in den Blick. Die empi- 
rische Basis dazu bilden narrative Paar- und Familieninterviews. Dazu suchen die Forschenden auch noch Familien, die an den Interviews teilnehmen möchten.

\section{Wissensportal LSBTI}

Der Gesundheit und sozialen Teilhabe lesbischer, schwuler, bisexueller, trans- und intergeschlechtlicher Menschen in Deutschland widmet sich das Wissensportal LSBTI, das die Arbeitsgruppe „Sozialmedizin und Public Health mit Schwerpunkt Geschlecht und Diversität" an der FH Dortmund ins Leben gerufen hat. Auf dem Portal werden bestehende Studien und Ressourcen zum Thema gebündelt und aufbereitet. Es stellt auch eine Möglichkeit dar, themenspezifische Abschlussarbeiten zu veröffentlichen. Damit soll „ein bedarfsgerechter, verschiedene Körperlichkeiten akzeptierender und diskriminierungsfreier Zugang zur Gesundheitsversorgung" gefördert werden (Journal des Netzwerks Frauen- und Geschlechterforschung NRW 2018, 27). Das Portal ist auch ein Ausgangspunkt für neue Forschungsarbeiten, da erstmals ein intersektionaler Überblick über das spezifische Zusammenspiel der Kategorien Gesundheit, sexuelle Identität, Alter, Migration, sozioökonomischer Status etc. erstellt wird. Zudem kann durch das Portal die Netzwerkbildung von Praktiker*innen, LSBTI-Community-Akteur*innen, Gesundheitsversorgung und Wissenschaft angeregt werden.

Mehr Infos unter Journal des Netzwerks Frauen- und Geschlechterforschung NRW. 42 (2018), 27.

Internet: www.wissensportal-lsbti.de

\section{Start des Forschungsprojekts „Engendering Migration, Development and Belonging: The Experiences of Recently Arrived Afghans in Europe“}

Dem Verbleib von Flüchtlingen aus Afghanistan in Dänemark, Deutschland, UK und der Schweiz widmet sich ein neues Forschungsprojekt, das vom Schweizer Netzwerk für Internationale Studien gefördert wird. Das Projekt untersucht, welchen Einfluss die in den Ursprungs- und Gastgebergemeinden der Geflüchteten vorherrschenden Vorstellungen von Geschlecht auf die Wünsche derselben in Bezug auf Heimat und Zugehörigkeit haben. Des Weiteren wird in den Blick genommen, wie die Gastgebergesellschaften diese Wünsche und Vorstellungen integrieren. Drittens wird die Rückwirkung der Flüchtlinge und ihrer Geschlechteridentitäten auf ihre Ursprungsländer betrachtet.

Das Projektteam setzt sich aus Forschenden der Université de Neuchâtel, Coventry University, Aarhus Universitet, des Swiss Refugee Council, des Graduate Institute Geneva, der University of Oxford sowie der University of London zusammen.

Internet: https://snis.ch/project/engendering-migration-development-and-belonging-the-experiences-ofrecently-arrived-afghans-in-europe/ 


\section{Anneliese Maier-Forschungspreis für Prof. Sylvia Walby}

Zur Förderung der Internationalisierung der Geistes- und Sozialwissenschaften vergibt die Humboldt-Stiftung den nach der Philosophin und Wissenschaftshistorikerin Anneliese Maier benannten Forschungspreis. Gefördert werden über einen Zeitraum von bis zu fünf Jahren Forschungskooperationen zwischen den Preisträger_innen und Fachkolleg_innen in Deutschland. Einer der acht jedes Jahr vergebenen Preise ging dieses Jahr an Prof. Sylvia Walby, Officer of the Order of the British Empire, Distinguished Professor of Sociology und UNESCO Chair in Gender Research, Director des Violence and Society UNESCO Centre an der Lancaster University, UK. Sylvia Walby ist auch Fellow in the Academy of Social Sciences and the Royal Society of the Arts.

Als Gastinstitution fungiert das Essener Kolleg für Geschlechterforschung. Dort wird Sylvia Walby gemeinsam mit Prof. Karen Shire, Mitglied des Vorstands des Essener Kollegs für Geschlechterforschung, zur Geschlechterdimension des Menschenhandels, der Transformation der Geschlechterbeziehungen im europäischen Vergleich sowie den Themen Geschlecht und Gewalt arbeiten.

Internet: https://www.uni-due.de/ekfg/walby.php

\section{Länderreport Deutschland des Projekts „Evaluation Framework for Promoting Gender Equality in Research and Investigation“ (EFFORTI) veröffentlicht}

Das Projekt EFFORTI veröffentlichte im Januar 2018 mehrere Länderreports zur Wirksamkeit von Gleichstellungsprojekten im Bereich Forschung und Innovation. Der Report sieht Auswirkungen der allgemeinen Familienpolitik auf den wissenschaftlichen Bereich insbesondere in den weiterhin bestehenden Anreizen für eine traditionelle Rollenaufteilung innerhalb von Partnerschaften und in vergleichsweise großzügigen Elternzeitregelungen. In Bezug auf Gleichstellungsprogramme wird der Wissenschaftsbereich gegenüber der Allgemeingesellschaft besonders hervorgehoben. Der Gender Pay Gap im Bereich Forschung und Innovation, so der Report, ist mit 19,3\% kleiner als in der Gesamtwirtschaft (22,3\%). Gleichzeitig betont der Report Grenzen der existierenden Gleichstellungsprogramme, etwa die Freiwilligkeit von Gleichstellungszielen und die Auswirkung von unsicheren Arbeitsbedingungen auf die Karriereaussichten von Personen mit Familien- und Pflegeverantwortung.

Weitere Informationen und der ausführliche Bericht unter folgendem Link: https://www.efforti.eu/ publications/country-reports

\section{Einrichtung des Open Gender Journal}

Das Margherita-von-Brentano-Zentrum der Freien Universität Berlin betreibt seit Herbst 2017 das Open Gender Journal als Möglichkeit des Open Access Publishing 
in den Gender Studies. Das Journal veröffentlicht ausschließlich Erstveröffentlichungen aus der Geschlechterforschung und verwandten Wissenschaftsbereichen.

Weitere Informationen sowie Zugang zu den bisher veröffentlichten Ausgaben unter: www. opengenderjournal.de

\section{Konferenz der Gleichstellungsminister_innen fordert systematische Einbeziehung von Genderperspektiven in Curricula}

Die Konferenz der Gleichstellungs- und Frauenministerinnen, -minister, -senatorinnen und -senatoren der Länder (GFMK) forderte auf ihrer Jahreshauptkonferenz im Juni 2018 die Förderung von Geschlechterforschung und von Frauen im Wissenschaftssystem. Zu diesem Zweck rief die Konferenz die Bundesregierung sowie wissenschaftliche Führungspositionen dazu auf, sechs Zielsetzungen zu verfolgen. Diese betreffen im Einzelnen die Weiterentwicklung von Gleichstellungsstrategien, die Überprüfung rechtlicher Rahmenbedingungen mit Hinblick auf ihre geschlechterspezifischen Auswirkungen, den Ausbau von Förderprogrammen von Frauen in der Wissenschaft, die Integration von Gender als inhaltlicher Dimension in die Forschungsförderung, die Berücksichtigung von Geschlechteraspekten als Qualitätsmerkmal bei der Prüfung von Forschungsanträgen sowie eine weitere Förderung der Geschlechterforschung etwa durch die Einrichtung von Gender-Professuren.

Der Beschluss in seiner Gänze findet sich unter folgendem Link: https://www. gleichstellungsministerkonferenz.de/documents/zusammenfassung-beschluesse-oeffentlich-28-gfmk2018-bremerhaven_2_1529402469.pdf

\section{Neue Veröffentlichungen zur geschlechtergerechten Hochschulkultur}

Die Bundeskonferenz der Frauen- und Gleichstellungsbeauftragten an Hochschulen veröffentlichte zwei Broschüren mit dem Ziel, Geschlechtergerechtigkeit weiter im Hochschulsystem zu verankern. Die Publikation „Gender 2020. Auf dem Weg zu einer geschlechtergerechten Hochschul- und Wissenschaftskultur" basiert auf einem aus Mitteln des Bundesministeriums für Bildung und Forschung geförderten Projekt und vereint Beiträge zu rechtlichen Rahmenbedingungen der Gleichstellung, zu Argumenten für Gleichstellungspolitik, zu gleichstellungspolitischen Innovationen und Erfolgen, Hindernissen und Impulsen für Geschlechtergerechtigkeit sowie zu verschiedenen Aspekten der Hochschulkultur. Der Leitfaden „Auf dem Weg zur Professur an einer Fachhochschule/Hochschule für angewandte Wissenschaften“ sammelt Hinweise und Informationen für Frauen, die eine entsprechende Position anstreben. Darunter befinden sich Angaben zu allen Phasen eines Bewerbungsverfahrens sowie Adressen einschlägiger Datenbanken. 


\section{Toolbox der Genderplattform an österreichischen Hochschulen}

Seit Januar 2018 betreibt die Genderplattform der Gleichstellungsakteur_innen und Geschlechterforscher_innen an österreichischen Hochschulen eine Online-Toolbox für Instrumente der universitären Gleichstellungsarbeit. Die Sammlung gliedert sich in die Bereiche Gendersensible Organisationskultur, Gleichstellungsorientierte Karriereentwicklung und Nachwuchsförderung, Steuerung, Management, Universitätsleitung, Geschlechtergerechte Ressourcenverteilung und Gender Budgeting, Integration der GenderDimension in Forschung und Lehre sowie Vereinbarkeit von Berufsleben, Familienleben und Lebensgestaltung. Die Rubriken bilden ein breites Spektrum an Ressourcen ab, von Publikationen über Verweise auf Kommunikationsplattformen und Vernetzungsmöglichkeiten bis hin zu themenspezifischen Workshop- und Mentoringangeboten.

Weitere Informationen sowie Zugang zur Toolbox unter: www.genderplattform.at

\section{Europäische Kommission unterstützt „No Women No Panel“ Kampagne}

EU-Kommissarin Mariya Gabriel startete im März 2018 eine Kampagne unter dem Titel „No Women No Panel“. Gabriel fordert darin, dass zu jedem Panel, zu dem sie eingeladen wird, mindestens eine weitere Frau eingeladen wird. Die Kampagne ist inspiriert von Datenbanken, die Profile von Expertinnen sammeln und sich die bessere Repräsentation von Frauen in politischen und wissenschaftlichen Plattformen zum Ziel setzen. Weitere Kommissionsmitglieder brachten ihre Unterstützung für die Initiative zum Ausdruck und die Europäische Kommission bezeichnete sie auf ihrer Nachrichtenseite als einen Schritt zur Umsetzung von Geschlechtergerechtigkeit.

Weitere Informationen unter: https://ec.europa.eu/digital-single-market/en/news/commissioners-

support-no-women-no-panel-campaign

\section{Digitaler Gleichstellungsatlas}

Eine interaktive digitale Version auf Grundlage des 3. Atlas zur Gleichstellung von Frauen und Männern in Deutschland (2017) ermöglicht es nun, online mit Daten zu geschlechtsspezifischen Unterschieden zu arbeiten. Die Daten sind mit interaktiven Karten aufbereitet. So zeigt z.B. ein Blick auf die regionale Verteilung des Gender Pension Gap große Unterschiede in den Alterssicherungseinkommen von Frauen und Männern ab 65 Jahren zwischen den Bundesländern: Während Rentnerinnen in Nordrhein-Westfahlen, Rheinland-Pfalz und Schleswig-Holstein $62 \%$ weniger Rente erhielten als Rentner, belief sich der Unterschied in Mecklenburg-Vorpommern und Sachsen auf unter 36\%. Die übrigen Bundesländer lagen dazwischen.

Der vom Bundesfrauenministerium veröffentlichte sogenannte digitale Gleichstellungsatlas bietet auch die Möglichkeit, ausgewählte Indikatoren oder sämtliche zugrunde gelegten Daten im CSF-Format herunterzuladen.

Mehr Informationen unter: https://www.bmfsfj.de/bmfsfj/service/gleichstellungsatlas?active=fpo 


\title{
Studium prekär
}

\author{
JANA GÜNTHER
}

Die aktuellen bundesdeutschen Maßnahmen in Hochschule und Forschung widmen sich nur in Ansätzen der sozialen und arbeitsrechtlichen Dimension. Gerade diese ist aber auf der Folie neuer Anforderungen hinsichtlich der Antidiskriminierungsgesetzgebung (AGG) sowie ganz prinzipieller Forderungen wie dem Schließen von „Gerechtigkeitslücken“, dem Abbau von „Bildungsarmut“ und mehr Chancengleichheit (Allmendinger 2016, 78) ganz wesentlich.

Insbesondere die Exzellenzstrategie, die Bolognareform und der Hochschulpakt dominier(t)en die politischen Diskurse. Stichworte sind hierbei zumeist Leistungsund Wettbewerbsfähigkeit (Bude 2011, 15) sowie Innovation und Qualitätsentwicklung (BMBF 2018; BMBF n.d.).

Die soziale Dimension von Lehre und Forschung im Bereich der Hochschule wird überwiegend von Interessengruppen - wie Gewerkschaften, Mittelbauinitiativen und verfassten Studierendenschaften - problematisiert. Im Folgenden werden die verschiedenen Diskursstränge der Debatte um die soziale Dimension aufgezeigt und ein Perspektivenwechsel hinsichtlich gerechter Studienfinanzierung diskutiert.

\section{Ausgangslage: „Prekär ist wer?“1}

Innerhalb der letzten Jahre haben sich in der öffentlichen wie akademischen Diskussion zwei spezifische Debattenstränge als besonders öffentlichkeitswirksam erwiesen: Erstens wird die soziale und oftmals als prekär bezeichnete Situation im Bereich Hochschule und Forschung zumeist hinsichtlich der Beschäftigten - insbesondere des wissenschaftlichen Nachwuchses - beleuchtet (u.a. de la Riva 2018, 26; Keller 2015a, 136ff.; Klecha/Reimer 2008, 14; Konsortium Bundesbericht Wissenschaftlicher Nachwuchs 2017, 125; Lange-Vester 2016, $21 \mathrm{ff}$;; Ullrich/Reitz 2018, 23f.). Dieser Diskursfluchtpunkt erstaunt nicht sonderlich, weil selbiger durchaus als ein Marker der vielbeschworenen „Abstiegsgesellschaft“ (Nachtwey 2016) oder der „Statuspanik“ der „,neuen Mitte“ (Bude 2011, 21f.) gedeutet werden kann. Bildung allein ist nicht mehr zwangsläufig ein Garant für sozialen Aufstieg (Nachtwey 2016, 154). So sind Abschlüsse eben auch eine „Währung, die das Sozialprestige bewerten und als Zugang zu Arbeitsplätzen gehandelt werden“, d.h. auch hier kann es zur Inflation kommen (Collins 2014, 67). Eine immer besser ausgebildete Masse an Menschen konkurriert um „obere Mittelschichtsjobs“ (ebd.). Dies betrifft auch den Hochschulbereich, sowohl die dort unterhalb der Professur Beschäftigten als auch die Studierenden, die in diese Erwerbsarbeitsbereiche drängen. Die Erwerbsarbeitslage des wissenschaftlichen Nachwuchses wird daher ganz zu Recht problematisiert, denn die damit einhergehenden Unsicherheiten hinsichtlich prekärer Biografien und finanzieller Engpässe, die sich durch Erwerbsarbeitsunterbre- 
chungen aufgrund der Teilzeitbefristungs- (TzBfG) und Wissenschaftszeitvertragsregelungen (WissZeitVG) auch auf die Sozial- und Rentenversicherung auswirken, bleiben eine ernstzunehmende soziale Herausforderung.

Nicht zuletzt gestaltet sich Lehre und Forschung als Erwerbsarbeitsort immer noch als ein exklusiver Ort bzw. als ,geschlossene Gesellschaft“ (Graf 2017), die bestimmte soziale Gruppen - insbesondere ab der Professur - exkludiert (Möller 2013, $341 \mathrm{ff}$., Graf 2017, 10f.), z.B. Menschen mit Migrationsgeschichte, People of Color, mit Behinderung oder chronischer Krankheit, bestimmte soziale Schichten sowie Frauen (mit und ohne Kindern). Diese Fragilität der Erwerbsarbeitsverhältnisse sowie fehlende Diversität beeinflusst denn u.U. auch die Qualität, Inhalte und Innovation von Forschung und Lehre selbst ganz wesentlich.

Letzteres beträfe auch die Studierendenschaft, die ihrerseits und als größte Interessengruppe an den Hochschulen, mit doch ganz eigenen Problemen in Bezug auf soziale Belange zu kämpfen hat. An diesen Gedanken anknüpfend lässt sich ein zweiter Debattenstrang aufzeigen, der sich in den letzten Jahren vermehrt in der Öffentlichkeit - wenngleich nicht mit derselben Konsistenz und politischen Wirkkraft - wiederfand, nämlich der der sozialen Herkunft der Studierenden. Hierbei wurde viel weniger auf die eigentliche Situation von Studierenden als sozialer Gruppe verwiesen, als darauf, dass besonders Arbeiter_innenkinder in geringerem Maße den Zugang zum Studium finden (Autorengruppe Bildungsberichterstattung 2018, 172; Coenen/König 2016, 177ff.; Urbatsch 2011, 22ff.). Andere Studien deuten umfassender darauf hin, dass insbesondere sogenannte „nichttraditionelle Studierende“, d.h. die nicht den Kriterien „25 Jahre alt, ledig, kinderlos, ohne niedrige (Bildungs-) Herkunft, Inländer_in ohne Migrationshintergrund, mit Hochschulzugangsberechtigung auf dem ersten Bildungsweg, in Vollzeit studierend und ohne körperliche und geistige Beeinträchtigung " (Trautwein 2016, 170) entsprechen, mit besonderen Herausforderungen hinsichtlich der Aufnahme und Durchführung eines Studiums konfrontiert werden. Ziel und Zweck müsse es demnach sein, das Studium sozial durchlässiger zu gestalten, um allen gesellschaftliche Teilhabe und Berufschancen zu ermöglichen. Letzteres ist jedoch vor dem Hintergrund des verschärften Wettbewerbs ,,in der Mitte“ (Münch 2016, 71) zumindest auf der Ebene des Erwerbsarbeitsmarktes illusorisch.

Die gute Nachricht ist: Mit der Zunahme der Studierendenzahl ${ }^{2}$ generell stellt sich auch eine größere Heterogenität der Studierendengruppe ein (Autorengruppe Bildungsberichterstattung 2018, 172; DGB 2016, 4; Middendorff/Apolinarski/Becker et al. 2017, 27). Für ,nichttraditionelle' Studierende oder studierende Arbeiter_innenkinder stellt sich die Frage der Studienfinanzierung demnach noch einmal dringender als für die sogenannten, traditionellen' Student_innen, doch legen aktuelle Debatten nah, nicht nur den Zugang, sondern die Lebensphase des Studiums in ihrer sozialen Dimension konsequenter und für die Studierendengruppe als Ganze in den Blick zu nehmen. 


\section{Soziale Situation von Studierenden: Armut, Wohnungsnot, Studienkosten}

„Lustig“ ist das „Studentenleben“ schon lange nicht mehr (Keller 2017, 18), was insbesondere studentische Interessenvertretungen ${ }^{3}$ und Gewerkschaften monieren und auf die sich verschärfende Lage für Studierende dezidiert hinweisen (u.a. DGB 2016; fzs 2011; Keller 2015b). Die Erwerbstätigenquote in der Studierendenschaft liegt seit 2016 bei $69 \%$ und damit so hoch wie noch nie (Middendorff/Apolinarski/ Becker et al. 2017, 60). Innerhalb dieser Gruppe studierender Beschäftigter gehen überdurchschnittlich viele Kinder aus hochschulbildungsfernen Familien einer Erwerbsarbeit nach (ebd., 62). Ein Teil - nämlich 55\% - der Studierenden mit ,niedriger" Bildungsherkunft gibt u.a. an, aus Angst vor Verschuldung ${ }^{4}$ keinen BAföGAntrag zu stellen (Middendorff/Apolinarski/Becker et al. 2017, 55). Generell ist die Rate für Studiendarlehen seit 2012 gestiegen (ebd., 43). Studierende nehmen, um ihren Status als selbige nicht zu gefährden und damit steuerliche, sozial- und krankenversicherungsrelevante Probleme (z.B. Kindergeld oder Familienversicherung der Krankenkasse) zu produzieren, zumeist geringfügige Jobs (450-Euro-Jobs) oder Teilzeitarbeitsverhältnisse (weniger als 20 Stunden) an. Arbeitende Studierende werden allerdings nicht als atypisch oder prekäre Beschäftigte wahrgenommen, da sie sich ihrem Status nach noch in der Ausbildungsphase befinden. Hierbei gilt es zu bedenken, dass dies erstens insgesamt arbeitsmarktpolitische Auswirkungen hat, da Studierende mit anderen Erwerbsarbeitstätigen um Arbeitsplätze konkurrieren. Zweitens hat diese Form der Beschäftigung nur geringen Mehrwert für spätere Sozial- und Rentenleistungen der Studierenden. Drittens verlängert sich aufgrund zunehmender Mobilitäts- und Studienanforderungen (z.B. Auslandsaufenthalte, Praktika) die Studienzeit noch einmal zusätzlich, oder die Qualität des Studiums sinkt für die Studierenden, da sie nicht inhaltlich, sondern effizienz- und zeitorientiert studieren (müssen).

Die Einkünfte - zumeist aus elterlicher Unterstützung und Erwerbsarbeitslohn zusammengesetzt - von Studierenden lagen im Jahr 2016 insgesamt bei rund $860 €$ (ebd., 39) und damit im Bereich der Armutsgefährdungsgrenze. ${ }^{5}$ In den ostdeutschen Bundesländern sind die Einkünfte noch niedriger als in den meisten westdeutschen (ebd., 40). Unter den Studierenden musste im Jahr 2016 zudem jede_r fünfte mit weniger als $670 €$ monatlich auskommen (ebd., 41) und gilt damit rein formal als arm. Das hat Folgen: Eine besondere Herausforderung für einen Großteil der Studierenden ist mittlerweile die sich verschärfende Mietsituation in den Hochschulstädten (Mersch 2017, 16f.). Die gestiegene Studierendenzahl bedingt auch einen erhöhten Wettbewerb auf dem Mietmarkt, gleichzeitig wird Wohnraum im urbanen Raum insgesamt knapper (Middendorff/Apolinarski/ Becker et al., 2017, 64). Für die wenigen BAföG-Empfänger_innen, die insgesamt nur ca. 18\% der Studierenden insgesamt ausmachen (ebd., 52), die den Höchstsatz von $735 €$ erhalten, ist regulär eine Wohnpauschale von etwa $250 €$ eingeplant (Pridik 2017), was kaum den durchschnittlichen Mietausgaben in Höhe von $323 €$ (Middendorff/Apolinarski/Becker et al. 2017, 48) 
von Studierenden entspricht. ${ }^{6}$ D.h., ob Berlin, Darmstadt, Dresden oder Kleve: Ein großer Teil der studentischen Einkünfte muss für Mietkosten einkalkuliert, eventuelle wohnliche Übergangslösungen zu Anfang des Studiums müssen zeitlich und finanziell in Kauf genommen, eine Aufnahme von Erwerbsarbeit erwogen und eine Nebenjobsuche organisiert werden, was wiederum zu einem ,Abrieb“ in der Studienleistung führen kann. Dies hat in der Folge Effekte auf die Beantragung und/oder Weiterförderung durch das BAföG, Stipendien oder Studiendarlehen. Zwar war es ein Ziel der Bologna-Reform, die Studienzeiten zu verkürzen, jedoch verbleiben durchschnittlich 84,8\% länger im BA und ca. 87,2\% länger im MA (Buschle/Hähnel 2016, 19), d.h. hier muss hinsichtlich der Finanzier- und Studierbarkeit nachgeforscht und politisch nachjustiert werden.

Die in den einzelnen Bundesländern immer wieder geführten Debatten um die Einführung von Studiengebühren tragen vermutlich zusätzlich zu einer allgemeinen Verunsicherung in der Studierendenschaft bei (Keller 2017, 18). Überhaupt spielen in der öffentlichen Diskussion um Hochschul- und Studienfinanzierung die Kosten für ein Studium eine geringe Rolle: Selbst wenn die Lebenserhaltungskosten nicht als Teil von Studienkosten eingerechnet werden, verbleibt doch ein wesentlicher Anteil an Ausgaben für Verwaltungs- bzw. Immatrikulationsgebühren, Kranken- und Pflegeversicherungsgebühren (ab 25 Jahren ca. $85 €$ monatlich), Mobilitätskosten (Semestertickets, Auslandsaufenthalte, Sprachkurse, Exkursionen), Arbeitsmittel (Kopien, Bücher, Software usw.) ${ }^{7}$, die Studierende aufbringen müssen. Zwar ermöglichen Online-Ressourcen in Bibliotheken oder virtuelle Kurse den Zugang zu kostenloser Seminarliteratur und notwendigen Programmen, doch auch hier stehen nicht an jedem Studienstandort die gleichen Zugangsmöglichkeiten (Lizenzen) zur Verfügung. Zudem werden eigene oder elterliche Zuzahlungen zu Büchern, die Anschaffungen von Rechnern (Laptop, Tablet) und anderen Lernmitteln sowie ein (mobiler) Internetzugang mittlerweile für ein Studium vorausgesetzt und als gegeben angenommen.

Bedenkt man all diese Punkte und stellt insbesondere den spezifischen Informations- und Beratungsbedarf, der bei Studierenden bei ungefähr 61\% liegt (Middendorff/Apolinarski/Becker et al. 2017, 70), die verlängerte Studienphase, die hohe Erwerbstätigenquote und die im Armutsrisikobereich liegenden durchschnittlichen Einkommenswerte in Rechnung, liegt es nahe anzunehmen, dass das Studium eine für viele Studierende durchaus prekäre Lebenslage darstellt. Nicht zuletzt verweisen auch die Abbruchquoten ${ }^{8}$ auf größere Fragilitäten im Hochschulbildungsbereich.

\section{Studienfinanzierung: Leistung und Wettbewerb statt soziale Gerechtigkeit}

In der BRD müssen Studierende zumeist auf eine Mischfinanzierung aus elterlicher Unterstützung und Erwerbsarbeit setzen. Nur jede_r Achte bezieht (Keller 2017, 18) überhaupt noch BAföG. Ein Teil der Studierenden liegt auch deutlich unter den BAföG-Referenzwerten in Bezug auf Ein- und Ausgaben sowie unter dem Hartz IV- 
Satz, wenn Miet- und Heizkosten mit eingerechnet werden. Hier handelt es sich um sogenannte ,verdeckte Armut ${ }^{\text {‘9 }}$ (Dohmen/Cleuvers/Cristóbal et al. 2017, 49). Eine letzte Novellierung hinsichtlich der Studienfinanzierung fand für das BAföG 2016 statt, konnte aber den allgemeinen Abwärtstrend nicht stoppen.

Mit dem Ausbau eines Stipendiensystems sollte neben BAföG und Bildungsdarlehensangeboten eine ,wichtige Säule in der Studienfinanzierung“ erbaut werden (BMBF 2015). Die Stipendien der Begabtenförderwerke richten sich nach den Vergabe- und Beantragungsregelungen des BAföGs, d.h. auch diese sind an das Einkommen und Vermögen der Eltern und der Studierenden gekoppelt. Dem entgegengesetzt wurde die Konzeption und Einführung des Deutschlandstipendiums 2010, bei welchem insbesondere begabte und leistungsstarke Studierende „unabhängig von sozialer Herkunft" (BMBF 2017) gefördert werden. Diese Anrufung der Unabhängigkeit sozialer Herkunft suggeriert auf problematische Weise zweierlei. Zum einen gibt es hier eben nicht die Hürde des Einkommens der Eltern beim Förderantrag, und zum anderen wird stark gemacht, dass jede_ $r$ - solange die erforderlichen Leistungen erbracht werden - von der Förderung profitieren kann. Bei näherer Betrachtung lassen sich jedoch gleich mehrere Fallstricke erkennen: Erstens beträgt die Förderung lediglich $300 €$ und ist damit eher als ein Zubrot denn als eine wirkliche Ausfinanzierung zu bewerten. Zweitens zeichnen sich die „Übergangsstellen innerhalb des Hochschulsystems“ immer noch durch „eine fortgesetzte Verzerrung der Teilhabe aus" (Autorengruppe Bildungsberichterstattung 2018, 172). Wettbewerbsorientierte Leistungsanforderungen an Studienfinanzierungsmöglichkeiten zu koppeln, meint eben nicht gerechte Bildungschancen für alle Studierenden und bewirkt gleichzeitig soziale Schließungsmomente sowie unsolidarisches Verhalten unter den Studierenden selbst. Drittens beziehen lediglich 25.947 Studierende (ebd.) das Deutschlandstipendium, also verschwindend wenige, bedenkt man die hohen Studierendenanteile in Deutschland (siehe Anmerkung 2).

Insgesamt finanzieren sich nur 5\% der Studierenden über Stipendien (Middendorff/ Apolinarski/Becker et al. 2017, 43), sodass hier nach wie vor nur von einem „Säulchen" (Günther 2010, 136) statt einer Säule der Studienförderung gesprochen werden kann. Insgesamt gesehen, ist die bundesdeutsche Studienfinanzierung unzureichend, und die soziale Situation der Studierendenschaft lässt demnach die bereits aufgestellte Behauptung zu, dass es sich bei der Lebensphase des Studiums um eine prekäre handelt.

\section{Bildungspolitik: Aufstiegschance oder sozialpolitischer Puffer?}

Nun wurden ,Lehrjahre‘ ja bekanntlich noch nie als ,Herr_innenjahre“ begriffen, definiert man Schule, Ausbildung und Studium als eine in der Lebensbiographie nicht auf Dauer angelegte Phase, deren Früchte man in der darauf folgenden Zeit als Erwerbstätige_r erntet. Doch diese Sichtweise ist problematisch. Wie eingangs erwähnt, legten Forschungsergebnisse immer wieder nahe, dass ein Studium kein 
Garant mehr für den Eintritt in den gehobeneren Erwerbsarbeitsmarkt oder gar für sozialen Aufstieg ist. Die Bildungsexpansion stößt damit auf lange Sicht an ihre Grenzen (Münch 2016, 71). Gerade bei der jüngeren Generation hat sich die „,typische Erwerbsbiografie“ also „insgesamt verändert“ (Nachtwey 2016, 153). D.h., dass eine sowieso schon verlängerte Ausbildungsphase, die sich prekär gestaltet, von einer ebenfalls prekären Erwerbsarbeitsphase abgelöst wird. Die Bildungsexpansion hat - neben den unbestreitbar gesellschaftlich positiven Effekten (Allmendinger 2016, 78ff.) - demnach auch eine Schattenseite: Die Idee, dass mehr Bildung in einer (wettbewerbsorientierten) Gesellschaft zu mehr Chancengleichheit, mehr Arbeitsplätzen und Wirtschaftskraft führe (Collins 2014, 69), liefert auch die Lösung für das Problem der immer stärker schrumpfenden Anzahl von Mittelschichtsarbeitsplätzen (ebd.): Menschen werden länger in der Bildungssphäre ge- und aus dem Erwerbsarbeitsmarkt herausgehalten (ebd.). Die bewusste politische Forcierung und Reorganisation zu wettbewerbsorientierten und nach privatwirtschaftlichen Maßstäben organisierten Hochschulen führt darüber hinaus nicht nur zu den benannten prekären Erwerbsarbeitsverhältnissen für wissenschaftlichen Nachwuchs und Lehrpersonal generell. Unter dem Druck, Kosten zu sparen, wird die Last der Finanzierung eben auch zunehmend auf die Studierenden und deren Eltern abgewälzt (ebd.).

Abschließend bleibt zu sagen, dass die soziale Lage der Studierenden alarmierend ist. ,Prekarität ist überall“" und macht eben auch vor dem Bildungswesen nicht halt (Bourdieu 1998, 96); sie betrifft fast alle Statusgruppen an Hochschulen und Universitäten. Sicherlich nicht abschließend für den Debattenaufschlag hier, doch als Fäden, die wieder aufzunehmen sind, schließe ich mit zwei Gedanken meine Ausführung: Prekäre Lebensverhältnisse beginnen erstens für eine breitere Masse an Menschen schon während der Ausbildungsphase und verstetigen sich unter den aktuellen Bedingungen biografisch. Längere Schul- und Studienphasen haben zudem sozialversicherungspflichtige Auswirkungen durch die atypischen Beschäftigungsverhältnisse während des Studiums, den späteren Eintritt in den regulären Arbeitsmarkt und ebenfalls spätere Familiengründung usw., d.h. Politikfelder wie Sozial-, Bildungs-, Arbeits- und Familienpolitik sind hier eng verzahnt und verhalten sich teilweise gegenläufig zueinander. Zweitens muss die soziale Situation von Studierenden selbst als eine Form prekären Lebens eben auch akademisch wahrgenommen, analysiert und in der Studien- und Lehrplanung ${ }^{10}$ viel dezidierter berücksichtigt werden.

\section{Anmerkungen}

1 Angelehnt an die gleichnamige Forschungsarbeit von Magdalena Freudenschuss (2013) stellt sich auch im Hochschulbereich die Frage, wer gilt als prekär und wer nicht?

2 Im Wintersemester 2002/03 sind 1.939.233 Studierende zu verzeichnen, im Wintersemester 2017/18 mit 2.842.224 schon fast eine Millionen mehr (Statistisches Bundesamt n.d.)

3 Die Studierendenschaften hatten auf europäischer Ebene insgesamt einen großen hochschulpolitischen Einfluss darauf, dass die soziale Dimension überhaupt im Bologna-Prozess berücksichtigt wurde (Brändle 2010, 107). 
4 Die Förderung nach dem Bundesausbildungsförderungsgesetz (BAföG) für Studierende besteht i.d.R. zur Hälfte aus einem zinslosen Staatsdarlehen und zur anderen Hälfte aus einem Vollzuschuss.

5 In der Armutsforschung wird in der Regel davon ausgegangen, dass die Armutsrisikoschwelle unter $60 \%$ des Median aller Nettoäquivalenzeinkommen der Bevölkerung innerhalb des Landes liegen (Statistische Ämter des Bundes und der Länder 2017).

6 Im Alternativen BAföG-Bericht von 2017 wurde noch von 311 Euro in Westdeutschland und ca. 304 Euro in Ostdeutschland ausgegangen (DGB 2017, 25).

7 Die Kosten für Bildung/Lernmittel werden unterschiedlich erfasst, die monatlichen Ausgaben variieren in verschiedenen Berichten zwischen 35 Euro und 98 Euro monatlich (Dohmen/ Cleuvers/Cristóbal et al. 2017, 36).

8 Im Bachelor liegen diese bei bundesdeutschen Studierenden bei ca. 29\% gesamt (Heublein/ Ebert/Hutzsch et al. 2017, 263), der Abbruch erfolgt im Durchschnitt nach 4,7 Semestern (ebd., V). Die Abbruchquote in den Masterstudiengängen liegt an den Universitäten bei 15\% und an Fachhochschulen bei 19\% (ebd., 268f.).

9 Von verdeckter Armut wird dann gesprochen, wenn eine Person Anspruch aus Transferleistungen hat, diese aber aus bestimmten Gründen nicht in Anspruch nimmt.

10 Für erwerbsarbeitende und/oder erziehende Studierende sind beispielsweise angemessene Lösungen für Teilzeit- oder Abendstudien immer noch selten. Für nachhaltige fachspezifische Konzepte hinsichtlich einer ausgewogenen und professionellen Lehrgestaltung, die Präsenz- und Fernstudiensegemente sinnvoll kombiniert, fehlen m. E. den Lehrkräften - vor dem Hintergrund der oftmals eigenen prekären Erwerbsarbeits- und Qualifikationssituation - die Ressourcen (und teilweise die hochschulinterne Ausstattung).

\section{Literatur}

Allmendinger, Jutta, 2016: Mehr Bildung, größere Gleichheit. Bildung ist mehr als eine Magd der Wirtschaft. In: Mau, Steffen/Schöneck, Nadine M. (Hg.): (Un-)Gerechte (Un-)Gleichheiten. Bonn, 74-81.

Autorengruppe Bildungsberichterstattung, 2018: Bildung in Deutschland 2018. Ein indikatorengestützter Bericht mit einer Analyse zu Wirkungen und Erträgen von Bildung. Bielefeld.

BMBF, n.d.: Der Bologna-Prozess - die Europäische Studienreform. Internet: https://www.bmbf. de/de/der-bologna-prozess-die-europaeische-studienreform-1038.html.

BMBF, 2015: Mehr als ein Stipendium. Die Angebote der Begabtenförderungswerke. Berlin.

BMBF, 2017: Das Deutschlandstipendium. Bundesministerium für Bildung und Forschung. Internet: https://www.bmbf.de/de/das-deutschlandstipendium-881.html (1.7.2017).

BMBF, 2018: Bologna Prozess betont akademische Freiheit als Voraussetzung eines global attraktiven Europäischen Hochschulraums. Internet: https://www.bmbf.de/de/bologna-prozess-betont-akademische-freiheit-als-voraussetzung-eines-global-attraktiven-5924.html (30.7.2018).

Bourdieu, Pierre, 1998: Prekarität ist überall. In: Pierre Bourdieu (Hg.): Gegenfeuer. Wortmeldungen im Dienste des Widerstands gegen die neoliberale Invasion. Konstanz, 96-102.

Brändle, Tobias, 2010: 10 Jahre Bologna-Prozess. Chancen, Herausforderungen und Problematiken. Wiesbaden.

Bude, Heinz, 2011: Bildungspanik. Was unsere Gesellschaft spaltet. München.

Buschle, Nicole/Hähnel, Sascha, 2016: Hochschulen auf einen Blick. Wiesbaden.

Coenen, Cara/König, Evamarie, 2016: Ohne Netz und doppelten Boden: Als Studierende der ersten Generation an die Uni. In: Femina Politica. Zeitschrift für feministische Politikwissenschaft. 25 (1), 177-182. 
Collins, Randall, 2014: Das Ende der Mittelschichtarbeit: Keine weiteren Auswege. In: Wallerstein, Immanuel Maurice/Collins, Randall/Mann, Michael/Derluguian, Georgi/Calhoun, Craig (Hg.): Stirbt der Kapitalismus? Fünf Szenarien für das 21. Jahrhundert. Frankfurt/M., 49-88.

DGB, 2016: Alternativer BAföG-Bericht. Berlin. Internet: http://jugend.dgb.de/meldungen/ studium/++co++3698a746-ed4a-11e6-81e2-525400d8729f (2.7.2018).

Dohmen, Dieter/Cleuvers, Birgitt A./Cristóbal, Víctor/Laps, Jochen, 2017: Ermittlung der Lebenshaltungskosten von Studierenden. Eine Studie im Auftrag des Deutschen Studentenwerks. Berlin.

fzs, 2011: Soziale Dimension als integraler Bestandteil der Akkreditierung. freier zusammenschluss der studentInnenschaften. Internet: https://www.fzs.de/2011/08/12/soziale-dimensionals-integraler-bestandteil-der-akkreditierung (1.7.2018).

Freudenschuss, Magdalena, 2013: Prekär ist wer? Der Prekarisierungsdiskurs als Arena sozialer Kämpfe. Münster.

Graf, Angela, 2017: Die Wissenschaftselite - eine geschlossene Gesellschaft? In: Lessenich, Stephan (Hg.): Geschlossene Gesellschaften. Verhandlungen des 38. Kongresses der Deutschen Gesellschaft für Soziologie in Bamberg 2016. Internet: http://publikationen.soziologie.de/index.php/ kongressband_2016/article/view/400 (31.7.2018).

Günther, Jana, 2010: Studienfinanzierung light. In: Femina Politica. Zeitschrift für feministische Politikwissenschaft. 19 (2), 135-140.

Heublein, Ulrich/Ebert, Julia/Hutzsch, Christopher/Isleib, Sören/König, Richard/Richter, Johanna/Woisch, Andreas (2017): Zwischen Studienerwartungen und Studienwirklichkeit. Ursachen des Studienabbruchs, beruflicher Verbleib der Studienabbrecherinnen und Studienabbrecher und Entwicklung der Studienabbruchquote an deutschen Hochschulen. Hannover.

Keller, Andreas, 2015a: Wissenschaftszeitvertragsgesetz auf dem Prüfstand. In: Femina Politica. Zeitschrift für feministische Politikwissenschaft. 24 (2), 136-140.

Keller, Andreas, 2015b: Stellungnahme der Gewerkschaft Erziehung und Wissenschaft (GEW) zum Öffentlichen Fachgespräch der Technikfolgenabschätzung im Deutschen Bundestag am Mittwoch, 20. Mai 2015. Die wirtschaftliche und soziale Lage der Studierenden. Ausschussdrucksache 18(18)104 b. Stellungnahme.

Keller, Andreas, 2017: Nicht lustig! In: Erziehung \& Wissenschaft. 69 (12), 18.

Klecha, Stephan/Reimer, Melanie, 2008: Wissenschaft als besonderer Arbeitsmarkt Grundtypologien des Umgangs mit unsicherer Beschäftigung beim wissenschaftlichen Personal. In: Klecha, Stephan/Krumbein, Wolfgang (Hg.), 2008: Die Beschäftigungssituation von wissenschaftlichem Nachwuchs. Wiesbaden, 13-87.

Konsortium Bundesbericht Wissenschaftlicher Nachwuchs, 2017: Bundesbericht Wissenschaftlicher Nachwuchs 2017. Statistische Daten und Forschungsbefunde zu Promovierenden und Promovierten in Deutschland. Bielefeld.

de La Riva, Miguel, 2018: Unter den Professoren: Die prekäre Universität. In: Blätter für deutsche und internationale Politik. 63 (1), 25-28.

Lange-Vester, Andrea, 2016: Zwischen W3 und Hartz IV: Zumutungen prekarisierter Arbeitsbedingungen für den (erziehungs-Jwissenschaftlichen Nachwuchs. In: Erziehungswissenschaft. 53 (2), 21-29.

Mersch, Britta, 2017: Zimmer frei? Immer seltener. In: Erziehung \& Wissenschaft. 69 (12), 16-17.

Middendorff, Elke/Apolinarski, Beate/Becker, Karsten/Bornkessel, Philipp/Brandt, Tasso/HeiBenberg, Sonja/Poskowsky, Jonas, 2017: Die wirtschaftliche und soziale Lage der Studierenden in Deutschland 2016. 21. Sozialerhebung des Deutschen Studentenwerks durchgeführt vom Deutschen Zentrum für Hochschul- und Wissenschaftsforschung. Internet: https://www.bmbf. de/pub/21._Sozialerhebung_2016_Hauptbericht.pdf (7.7.2018).

Möller, Christina, 2013: Wie offen ist die Universitätsprofessur für soziale Aufsteigerinnen und Aufsteiger? In: Soziale Welt. 64 (4), 314-360. 
Münch, Richard, 2016: Mehr Bildung, größere Ungleichheit. Ein Dilemma der Aktivierungspolitik. In: Mau, Steffen/Schöneck, Nadine M. (Hg.): (Un-)Gerechte (Un-)Gleichheiten. Bonn, 65-73.

Nachtwey, Oliver, 2016: Die Abstiegsgesellschaft. Über das Aufbegehren in der regressiven Moderne. Berlin.

Pridik, Nicola, 2017: BAföG-Bedarf. Höhe der Förderung - Leistungsbedarf. Internet: https:// www.bafoeg-aktuell.de/bafoeg/bedarf.html (1.7.2018).

Statistische Ämter des Bundes und der Länder, 2017: Armut und soziale Ausgrenzung. Internet: http://www.amtliche-sozialberichterstattung.de/A2armutsgefaehrdungsschwellen.html (1.7.2018).

Statistisches Bundesamt, n.d.: Anzahl der Studierenden an Hochschulen in Deutschland vom Wintersemester 2002/2003 bis 2017/2018. In: Statista - Das Statistik-Portal. Internet: https:// de.statista.com/statistik/daten/studie/221/umfrage/anzahl-der-studenten-an-deutschen-hochschulen/ (25.7.2018).

Trautwein, Peggy, 2016: Nichttraditionelle Bildungswege als Aspekt studentischer Heterogenität an den Hochschulen in Sachsen-Anhalt. In: Femina Politica. Zeitschrift für feministische Politikwissenschaft. 25 (1), 170-177.

Ullrich, Peter/Reitz, Tilmann, 2018: Raus der prekären Mobilität. In: FORUM Wissenschaft. 35 (2), 23-24.

Urbatsch, Katja, 2011: Studierende der ersten Generation an deutschen Hochschulen gewinnen und fördern. In: Heinrich Böll Stiftung (Hg.): Öffnung der Hochschule. Chancengerechtigkeit, Diversität, Integration. Berlin, 22-26.

\section{Strategien für eine gender- und diversitätssensible Hochschuldidaktik}

\section{DAVID KERGEL. BIRTE HEIDKAMP-KERGEL}

Aktuelle Formen einer gendersensiblen Hochschuldidaktik sind dem machtanalytischen Turn in diesem Feld zuzurechnen, der eingangs vorgestellt wird. So kann eine Verortung gendersensibler Didaktik innerhalb des hochschuldidaktischen Diskurses geleistet werden. Das einer zeitgemäßen geschlechtersensiblen Hochschuldidaktik zugrundeliegende Genderverständnis lässt sich anhand einer genealogisch orientierten Rekonstruktion der Thematisierung von Gender im hochschulischen Bildungsraum herausarbeiten. Vor dem Hintergrund dieser analytischen Rahmungen werden im folgenden Beitrag Eckpunkte einer gendersensiblen Hochschuldidaktik vorgestellt.

\section{Von der Bologna-Reform zum machtanalytischen Turn in der Hochschuldidaktik}

Der hochschuldidaktische Diskurs rückte im Kontext der Bologna-Reform Ende der 1990er Jahre/zu Beginn der 2000er Jahre verstärkt in den Fokus der Hochschul- 
öffentlichkeit: In der Sorbonne-Erklärung von Frankreich, Deutschland, Großbritannien und Italien wurde 1998 eine erste Harmonisierung des europäischen Hochschulraums beschlossen. 1999 schlossen sich mit der Bologna-Erklärung 29 weitere Staaten dieser Zielsetzung an. Diese Neujustierung des europäischen Bildungsraums wurde von einer bis heute anhaltenden Intensivierung des hochschuldidaktischen Diskurses flankiert. So wurde 1995 von Barr und Tagg 1995 der wirkmächtige Artikel „From Teaching to Learning - A New Paradigm for Undergraduate Education“ veröffentlicht. Barr und Tagg plädieren im Bereich der „undergraduate education“ für einen hochschuldidaktischen Paradigmenwechsel, der zu einer stärkeren Lerner*innen-Zentrierung und einer Verabschiedung von instruktionsorientierten Lehr-/Lernszenarien führt. Konstruktivistische und damit kompetenzorientierte Lehr-/Lernszenarien stellen ,die Studierenden und ihren Kompetenzerwerb in den Mittelpunkt“" und „,eröffnen (...) Möglichkeiten für einen Paradigmenwechsel von einer lehrenden- zu einer studierendenzentrierten Haltung“" (Messner 2016, 5). Die Hochschuldidaktik hat sich folglich ,im Schatten des Bologna-Prozesses weiterentwickelt und einen unvermuteten Aufschwung genommen“ (Wildt 2013, 39). Dieser Diskurs um die Anforderungen einer kompetenzorientierten Lehre war bzw. ist zumeist von einem (sozio-)konstruktivistischen lerntheoretischen Verständnis geprägt. Die studierendenzentrierte Kompetenzgenerierung im Kontext konstruktivistisch orientierter Lehr-/Lernszenarien geht von Studierenden aus, die ihr Wissen im sozialen Kontext selbst generieren, validieren und stets neu infrage stellen. Im Rahmen eines solchen konstruktivistisch orientierten Lehr-/Lernverständnisses geraten machtanalytische Strukturen aus dem Blick, in die Studierende ebenso wie Lehrende eingebunden sind. Der Prozess der Wissensgenerierung im hochschulischen Bildungsraum und auch der Zugang zu diesem selbst ist aber signifikant von ökonomischem und sozialem Kapital abhängig (Bourdieu/Passeron 1998; Bildungsbericht 2018). Diese Erkenntnisse restrukturieren sukzessive den hochschuldidaktischen Diskurs. Zunehmend lässt sich von einem machtanalytischen Turn in der Hochschuldidaktik sprechen. Dieser machtanalytische Turn zeichnet sich über die Problematisierung von Differenzkategorien wie Gender, ökonomischer Hintergrund der Akteur*innen, etc. aus. Ein unreflektierter Umgang mit diesen Differenzkategorien, so die grundlegende Argumentation im Kontext des machtanalytischen Turns, reproduziert gesellschaftliche Ungleichheiten im hochschulischen Bildungsraum. Daher gilt es, hochschuldidaktische Strategien zu entwickeln, die einen konstruktiv-emanzipativen Umgang mit Differenz jenseits essentialistischer Identitätskonzepte und der Verfestigung von Differenzkategorien ermöglichen. Die Ansätze einer gendersensiblen Lehre sind dieser machtanalytischen Perspektivierung von Hochschuldidaktik zuzurechnen. Dabei ist die Thematisierung von Gender im hochschulischen Bildungsraum anhaltenden diskursiven Transformationen unterworfen. Die aktuelle Ausdefinierung einer gendersensiblen Hochschuldidaktik erschließt sich mit einem analytischen Blick auf diese diskursiven Transformationen, der im Folgenden gegeben wird. Aufbauend auf den Erkenntnissen gender- und diversitätstheoretischer 
Diskurse lassen sich Eckpunkte für Handlungsstrategien einer gender- bzw. diversitätssensiblen Hochschullehre entwickeln.

\section{Von der Frauenförderung zu einem dekonstruktivistischen Genderverständnis in der Hochschuldidaktik}

Wenn von Gender in der Hochschuldidaktik die Rede ist, lohnt für eine Begriffsschärfung eine historisch orientierte Analyse: So entstanden im Zuge der Protestbewegungen im Kontext der 1960er und 1970er Jahre nicht nur erste hochschuldidaktische Initiativen und Institutionalisierungen (Giebler-Müller 2018). Der Emanzipationsanspruch der Protestbewegungen führte auch zu einer Sensibilisierung bzgl. der Frauenförderung (FF). So wurde im Zuge der 1960er Jahre die Benachteiligung von Frauen verstärkt mit der Zielsetzung thematisiert, u.a. über Quotierungsregeln für Frauen, Frauenförderpläne, Verbesserung der Aus- und Weiterbildung, Unterstützung bei der Rückkehr in den Beruf nach einer Familienphase etc. geschlechtsspezifische Ungleichheiten abzubauen.

Auf institutioneller Ebene fand dieser Ansatz seinen Niederschlag in für den öffentlichen Dienst geltenden Gleichstellungsgesetzen auf Bundes- und Landesebene sowie in der Einrichtung von Stellen für Frauenbeauftragte (in Westdeutschland) beziehungsweise Gleichstellungsbeauftragte (in Deutschland) und entsprechender innerbetrieblicher Strukturen. (Degele 2008, 152, Fn1)

Ende der 1970er Jahre wurde der Ansatz der Frauenförderung durch das Modell des Gender Mainstreamings (GM) erweitert. Grundsätzlich ist GM durch die Ausrichtung geprägt, eine einseitige Fokussierung des Frauenförderungsansatzes zu überwinden. Auf den UN-Weltfrauenkonferenzen in Nairoibi (1985) und in Bejing (1995) ist dementsprechend der GM-Ansatz wirkmächtig gefördert worden. So wurde beispielweise in Bejing eine Aktionsplattform gegründet. Die Unterzeichnerstaaten, die diese Aktionsplattform unterstützen, verpflichteten sich dazu, GM im Verwaltungshandeln umzusetzen. Dementsprechend ist auch GM seit 1999 in der EU Bestandteil der Gleichstellungs- und Antidiskriminierungspolitik und bildet ein durchgängiges Leitprinzip der Bundesregierung. Zudem gibt es seit 2000 auf kommunaler Ebene sowie auf Ebene der Länder Strategien zur Realisierung von GM.

Konzeptionell zeichnet sich GM dadurch aus, Strategien zum Abbau von ungleicher Ressourcenverteilung zwischen Frauen und Männern zu entwickeln und zu implementieren. Geschlechtergerechtigkeit wird im GM nicht „länger als Gruppeninteresse formuliert, sondern als Querschnittsaufgabe, die alle AkteurInnen in der jeweiligen Organisation zu lösen haben“ (Schenk 2008, 154).

Im Bildungsraum Hochschule zeigt sich der GM-Ansatz mehr oder weniger explizit u.a. auf der Ebene der Studienorganisation. So wird beispielsweise bei Studiengängen im Bereich der Frühkindpädagogik der geringe Anteil männlicher Studierender problematisiert, während beispielsweise im Bereich des IT-Studiums auch 
frauenspezifische Studiengänge angeboten werden: An der Hochschule Technik und Wirtschaft Berlin existiert z.B. der Frauenstudiengang Informatik und Wirtschaft und an der Hochschule Bremen der internationale Frauenstudiengang Informatik. Flankiert werden solche Studiengänge von Initiativen wie dem Girls` and Boys` Day.

Der GM-Ansatz ist eher auf der Mesoebene hochschulinterner Organisationsentwicklung zu verorten. Auf der Ebene der Hochschuldidaktik hat sich dagegen ein Genderverständnis durchgesetzt, das gemäß der eher dekonstruktivistischen Ausrichtung des machtanalytischen Turns die Konstruktion von Geschlecht und Geschlechterhierarchien sowie Abhängigkeitsverhältnisse im Allgemeinen kritisch adressiert. Die Rezeptionslinien des machtanalytischen Turns stehen dabei in der Tradition poststrukturalistischer Theoriebildung. So etablierte sich im deutschsprachigen erziehungswissenschaftlichen Feld spätestens seit Ende der 1990er Jahre ein „,machtsensibles“ (Walgenbach 2014, 103) bzw. machtkritisch dekonstruktivistisches Vielfalts- bzw. Diversitätsverständnis. Ein solches dekonstruktivistisches Diversitätsverständnis schließt Fragen nach der Thematisierung von Geschlechtergleichheit und Fragen der Konstruktion von Geschlechteridentität im pädagogischen Kontext integrativ mit ein: „Machtkritische Diversity-Ansätze sehen soziale Identitäten und Zugehörigkeiten als Produkte von Herrschaftsverhältnissen wie Rassismus, Antisemitismus, Heteronormativität, Sexismus oder Behindertenfeindlichkeit“ (ebd., 104).

Der sich seit Mitte der 2000er Jahre im pädagogischen Feld etablierende machtkritische Diversitätsansatz (ebd., 103f.) entfaltet sich im Zuge des machtanalytischen Turn auch auf Ebene der Hochschuldidaktik. Ausgangsüberlegung ist der Kritikpunkt, dass Ansätze wie FF und GM eher personenzentriert und quantitativ orientiert nach Geschlechterrepräsentanz in institutionellen Gefügen bzw. nach Gleichverteilung fragen. Im Zuge eines machtkritischen Genderverständnisses gerät dagegen die Strukturebene selbst in den Blick. Im Sinne des Doing Difference bzw. Doing Gender werden institutionell präfigurierte soziale Praktiken problematisiert, welche zu der performativen Rekonstruktion von Geschlechteridentitäten beitragen. Auf der Ebene der Hochschuldidaktik wird zumeist in Form von konzeptionellen Überlegungen zunehmend thematisiert, wie im Lehrgeschehen Formen des Doing Gender abgeschwächt und entdramatisiert werden können. Hintergrund bildet die Annahme, dass präfigurierte Gendersubjektivitäten Menschen in normative Muster sozialisieren, die nicht den Ansprüchen einer selbstgewählten (Geschlechts-)Identität entsprechen (Wilchens 2007).

\section{Neue Formen des Lehrens - Strategien einer dekonstruktivistischen gendersensiblen Hochschuldidaktik}

Im Sinne des komplexen Strukturverständnisses poststrukturalistischer Ansätze wird Gender als eine - wenn auch grundlegende, da jede*n Akteur*in betreffende 
- Diversitätsdimension thematisiert. Eine machtkritische Hochschuldidaktik ist als eine dekonstruktivistische diversitätssensible Hochschuldidaktik zu begreifen, die sich durch Lehr-/Lernstrategien definiert, die darauf ausgerichtet sind, Identitätsfestschreibungen und die damit verbundenen Schematisierungen, Diskriminierungen und Stigmatisierungen abzuschwächen und zu entdramatisieren. Gerade wenn Geschlecht als Identitätskategorie in den Fokus rückt, kann dies zu einer Dramatisierung und performativen Stärkung von geschlechterspezifischen Differenzlinien führen. Dem Spannungsverhältnis zwischen Problematisierung und Dramatisierung lässt sich u.a. dadurch begegnen, dass in gegebenen Beispielen stereotypisch entgegenlaufende weibliche und männliche Formen verwendet oder das generische Maskulinum durch ein generisches Femininum ersetzt wird. Hierdurch kann es in der Hochschullehre - unabhängig vom jeweiligen Fach - zu Irritationen kommen. Irritationen wiederum stellen heuristische Bedingungen für das Aufbrechen konventionalisierter Wissensformationen - in diesem Fall geschlechtsspezifische Selbstverständlichkeiten - dar.

Neben dieser Strategie der Irritation und Entdramatisierung empfiehlt sich für eine geschlechts- bzw. diversitätssensible Hochschullehre im Allgemeinen die Verwendung von Lehr-/Lernformaten, die durch kollaborative Arbeitsformen eine diskursive Transzendierung von sozialen Zugehörigkeitskategorien ermöglichen. Im Zentrum stehen dabei sogenannte „neu(e) Formen des Lehrens“ (Bouffier/Kehr/ Lämmerhirt et al. 2014, 61) wie das problembasierte oder forschende Lehren bzw. Lernen (Kergel/Heidkamp 2015, 2016). Lehr-/Lernformen wie das forschende Lernen basieren auf einer sozialkonstruktivistischen Studierendenpartizipation. Im Sinne des Empowerment-Gedankens kritischer Pädagogik werden Studierende als Akteur*innen begriffen, die kritisch reflektieren, eigenverantwortlich und selbstgesteuert sowie dialogisch bzw. polylogisch miteinander Wissen konstruieren. Gerade die dialogische bzw. polylogische Struktur der „,neuen Lehrformen“ eröffnet einen Diskursraum, in dem die Diversität der Studierenden vielfältige Perspektiven auf Lehrgegenstände ermöglicht. Dieser Diskursraum führt im Idealfall zu einer Multiperspektivität, durch welche die Beschränkungen einer identitätsspezifischen Sichtweise aufgehoben werden können: Im polylogischen Austausch geraten identitätsspezifisch gerahmte Wissensbestände in Bewegung, indem neue Wissensformen entstehen. Dementsprechend gilt es im Sinne eines machtkritischen, dekonstruktivistischen gender- bzw. diversitätssensiblen Ansatzes Lehren und Lernen im hochschulischen Bildungsraum

nicht auf die Vermittlung gegebenen Wissens zu reduzieren, sondern vielmehr als kontingente Herstellung von Wissen zu verstehen (...), als ergebnisoffener und unabschließbarer Prozess des Ausverhandelns einer Vielzahl unterschiedlicher Positionen und Interessen, $\mathrm{zu}$ dessen Gestaltung und Wirkung alle Beteiligten entscheidend beitragen (Lummerding 2012, 48). 
Neben den emanzipatorisch-kollaborativen Strategien der „neuen Formen des Lehrens", die darauf abzielen, Studierende als Akteur*innen einer kritisch-reflexiven, dekonstruktivistischen Wissensproduktion im polylogischen Kontext zu adressieren, lassen sich auch andere Formen einer dekonstruktivistischen (Hochschul-) Lehre identifizieren. Als ein paradigmatisches Beispiel lassen sich Formen des forschenden Lernens verstehen, die von Akteur*innen initiiert werden, die sich selbst als marginalisierte Gruppen verstehen. Die Ausgrenzung und Diskriminierungserfahrungen werden durch forschendes Lernen wie im Forschungskollektiv des Boston Womens Health Club (Boston Women's Health Collective 1970; Kergel/Heidkamp 2018) im Bereich der Frauenemanzipation kritisch-emanzipativ aufgearbeitet. In derartigen Ansätzen, die in der Tradition der kritischen Pädagogik stehen, würde sich eine marginalisierte Gruppe durch ihre forschend lernende Auseinandersetzung mit erfahrenen gesellschaftlichen Ausgrenzungen als widerständiger Akteur* konstituieren. Dieser Gedanke verdient im Sinne einer emanzipativen Repolitisierung der Hochschule eine zukünftig zu leistende hochschuldidaktische Ausformulierung, da er die partizipativ-emanzipativen Potenziale von Hochschuldidaktik weiter vorantreibt.

\section{Literatur}

Barr, Robert B./Tagg, John, 1995. From Teaching to Learning - A New Paradigm for Undergraduate Education. In: Change. 27 (6), 13-25.

Bildungsbericht, 2018: Nationaler Bildungsbericht. Internet: https://www.bildungsbericht.de/de/ nationaler-bildungsbericht. (22.7.2018).

Bourdieu, Pierre/Passeron, Jean-Claude, 1988: Die Illusion der Chancengleichheit. Untersuchungen zur Soziologie des Bildungswesens am Beispiel Frankreichs. Stuttgart.

Bouffier, Anna/Kehr, Petra/Lämmerhirt, Miriam/Leicht-Scholten, Carmen, 2014: Spätes Erwachen an deutschen Hochschulen: Die „Entdeckung“ der Lehre und Berücksichtigung von Gender und Diversity. In: Tomberger, Corinna (Hg.): Gender- und Diversity-Kompetenzen in Hochschullehre und Beratung: Institutionelle, konzeptionelle und praktische Perspektiven. Hildesheim, 53-68.

Boston Women's Health Collective, 1970: Women and their Bodies. A Course. Boston.

Degele, Nina, 2008: Gender/Queer Studies. Paderborn.

Giebler-Müller, Ute, 2018: Hochschuldidaktische Positionen von der „Revolution durch Didaktik“ zur „Didaktisierung von Bildung“ In: Platte, Andrea/Werner, Melanie/Vogt, Stefanie/Fiebig, Heike (Hg.): Praxishandbuch Inklusive Hochschule. Weinheim, 43-54.

Kergel, David/Heidkamp, Birte, 2015: Forschendes Lernen mit digitalen Medien. Ein Lehrbuch. \#theorie \#praxis \#evaluation. Münster.

Kergel, David/Heidkamp, Birte, 2016: Forschendes Lernen 2.0. Partizipatives Lernen zwischen Globalisierung und medialem Wandel. Wiesbaden.

Kergel, David/Heidkamp, Birte, 2018; „It was dynamic! We all learned together” Forschendes Lernen diversitätssensibel gedacht - Didaktische Strategien für eine emanzipative Kompetenzentfaltung. In: Kergel, David/Heidkamp, Birte (Hg.): Praxishandbuch Habitussensibilität und Diversität in der Hochschullehre. Wiesbaden, i.E.

Lummerding, Susanne, 2012: Diversifizieren. Zur Interrelation der Produktion von Wissen und der Produktion von Differenz. In: Heitzmann, Daniela/Klein, Uta (Hg.): Diversity konkret gemacht. Wege zur Gestaltung von Vielfalt an Hochschulen. Weinheim, 45-60. 
Messner, Elgrid, 2016: Hochschuldidaktische Herausforderungen zwischen Bologna und Humboldt. In: Steirische Hochschulkonferenz (Hg.): Qualität in Studium und Lehre, Lernweltforschung 26. Wiesbaden, 5-7.

Schenk, Christian, 2008: Frauenförderung, Gender Mainstreaming und Diversity management, Gleichstellungspolitische Praxen im Lichte der Geschlechterforschung. In: Degele, Nina: Gender/ Queer Studies. Paderborn, 149-165.

Walgenbach, Katharina, 2014: Heterogenität - Intersektionalität - Diversity in der Erziehungswissenschaft. Opladen.

Wilchins, Riki, 2006: Gender Theory. Eine Einführung. Berlin.

Wildt, Johannes, 2013: Entwicklung und Potentiale der Hochschuldidaktik. In: Heiner, Mathias/ Wildt, Johannes ( $\mathrm{Hg}$.): Professionalisierung der Lehre. Perspektiven formeller und informeller Entwicklung von Lehrkompetenz im Kontext der Hochschulbildung. Bielefeld, 27-57. 


\title{
REZENSIONEN
}

Hürcan Aslı Aksoy (Hg.)

\section{Patriarchat im Wandel. Frauen und Politik in der Türkei}

\author{
HELIN RUF-UÇAR
}

Der Band vereint mehrere deutsch- und englischsprachige Beiträge von Wissenschaftlerinnen, die in Deutschland oder der Türkei lehren und forschen. Ziel ist, den Einfluss politischer und gesellschaftlicher Entwicklungen auf die Geschlechterverhältnisse in der Türkei darzustellen. Dabei untersuchen die Autorinnen aus historischen, politischen, gesellschaftlichen und strukturellen Perspektiven die Entwicklungen der letzten Jahre und fragen, welche Rolle Frauen im politischen und gesellschaftlichen Wandel spielen, welche Rechte Frauen in der Türkei haben, wie die unterschiedlichen Frauenbewegungen zueinander stehen und wie diese mit dem Wiedererstarken des Patriarchats umgehen. Jeder Beitrag wird dabei politisch und gesellschaftlich in Kontext gesetzt: die Gezi-Park-Proteste 2013, der erneute Ausbruch des Konflikts mit der PKK 2016, der militärische Putschversuch im Juli 2016 sowie der im Anschluss ausgerufene Ausnahmezustand, der zu einer Entlassungswelle von über 125.000 Staatsbediensteten und zahlreichen Verhaftungen führte. Die Beiträge decken somit verschiedene Forschungsthemen ab und richten sich an eine breite Leserschaft, die Interesse an den Entwicklungen in der Türkei aus einer Gleichstellungsperspektive hat.

Das Buch Patriarchat im Wandel ist in drei Abschnitte gegliedert. Im ersten Teil des Buches, „Geschlechterregime und Politik in der Türkei“, werden die verschiedenen Entwicklungsetappen des Geschlechterregimes aus historischer und rechtlicher Perspektive vorgestellt.

Die Entwicklung der Frauenrechte seit Gründung der Republik wird im Beitrag von Hürcan Aslı Aksoy sehr detailliert abgebildet. Aksoy weist darauf hin, dass die Institutionalisierung von gleichstellungspolitischen Fragen und die rechtliche Anpassung an internationale und europäische Vorgaben (neues Zivilgesetzbuch, Revision des Arbeits- und Strafrechts, Gesetze zum Schutz vor häuslicher Gewalt) seit 2002 stetig zugenommen haben. Jedoch verstärkt der politische Diskurs der Partei für Gerechtigkeit und Entwicklung (Adalet ve Kalkınma Partisi, AKP) ein konservatives Frauenbild und ein patriarchales Geschlechterverhältnis und konterkariert somit die während der ersten Legislaturperiode (2002-2007) von den Frauenbewegungen vorangebrachten rechtlichen Errungenschaften.

Renate Kreile geht in ihrem Beitrag vor allem der Frage nach, warum mehr Frauen als Männer die AKP unterstützen. Kreile analysiert in diesem Zusammenhang die 
Vor- und Nachteile eines kemalistischen Staatsfeminismus sowie die Traditionalisierung der Geschlechterrollen durch die AKP-Regierungen und schlägt vor, nach strukturellen Rahmenbedingungen zu fragen, die die Mobilisierungskraft der verschiedenen Deutungsangebote erklären. In diesem Zusammenhang arbeitet sie heraus, dass die soziale Absicherung und politische Anerkennung der Care-Tätigkeiten von Frauen tatsächlich wichtige Gründe dafür darstellen, dass Frauen den von der AKP vertretenen patriarchalen Geschlechtervertrag überzeugt mittragen.

Im zweiten Teil des Buches liefern die Beiträge einen Überblick zu den politischen Handlungsfähigkeiten der „Frauenbewegungen unter dem AKP Regime“ und beleuchten die staatliche Frauenpolitik.

Bihter Somersan zeichnet die unterschiedlichen Interessen der säkularen, religiös-konservativen, kurdischen, autonomen, sozialistischen und LGBTI Gruppen in der Türkei und ihren jeweiligen Entstehungskontext nach. Somersan stellt dabei fest, dass Regierungen seit Entstehung der Republik Frauenbelange politisch instrumentalisieren und abwerten, und dass sich dieser Prozess durch die AKP-Regierungen zusehends verschärft hat. Die Bekräftigung der konservativen Frauenrollen als Mütter, Ehefrauen und Pflegekräfte für Angehörige werden sowohl durch die neuen Regelungen, Gesetze und Sozialhilfeleistungen, als auch durch die fehlenden Maßnahmen der Regierung zur Erhöhung des Frauenanteils in Politik und Wirtschaft determiniert.

Der Beitrag von Ayşe Dursun zum Aufstieg von konservativen Frauen-Nichtregierungsorganisationen (NGOs) beleuchtet die zunehmende Ausgrenzung regierungskritischer Frauengruppen aus dem politischen Diskurs. Seit der zweiten Legislaturperiode der AKP werden sogenannte GONGOs (Government-organised NGOs) gegenüber den Frauen-NGOs bevorzugt, die die konservative, religiöse und nationalistische Rhetorik der AKP unterstützen. Als Beispiel für eine Frauen-GONGO untersucht Dursun den Verein KADEM (Der Verein für Frau und Demokratie) und stellt fest, dass Organisationen dieser Art das Ziel verfolgen, die Frauenbewegungen in der Türkei zu kooptieren und eine islamisch orientierte AKP-nahe Tagesordnung durchzusetzen.

Íclal Ayşe Küçükktrca untersucht in ihrem englischsprachigen Beitrag, welche Funktion Solidarität bzw. intersektional ausgerichtete Koalitionen für die Interaktion der kurdischen und der türkischen Frauenbewegungen in der Türkei erfüllen. Sie stellt fest, dass der bewaffnete Konflikt zwischen dem Militär und der PKK die Solidarität und die themenspezifischen Koalitionen beider Frauenbewegungen gefährden. In ihrem Beitrag diskutiert sie die Kontextfaktoren, die eine Zusammenarbeit befördern oder verhindern, und konzentriert sich insbesondere auf die Selbstbeschreibungen beider Frauenbewegungen.

Der englischsprachige Beitrag von Nil Mutluer analysiert die Auseinandersetzung von kemalistischen Feministinnen mit den Themen Kopftuch, Militarismus, Familie, Geschlecht, Sexualität und Nationalismus. Sie arbeitet dabei die Unterschiede zwischen reformistischen und konservativen Strömungen kemalistischer Feminis- 
tinnen in diesen Themenbereichen heraus. Die Reformistinnen zeichnen sich durch einen inklusiven Ansatz aus, der die Forderungen muslimischer und kurdischer Frauengruppen berücksichtigt, sich jedoch gegen die politische Instrumentalisierung von Frauenrechten ausspricht. In diesem Zusammenhang haben beide Strömungen gemeinsam, dass sie die anti-demokratische und ausgrenzende Mentalität der AKP kritisieren.

Im dritten Teil des Buches „Soziale Dynamiken der Geschlechterverhältnisse“ beschäftigen sich die Autorinnen mit den strukturellen Ungleichheiten sowie der Entsäkularisierung der Gesellschaft in der Türkei.

Çağla Ünlütürk Ulutaş beschreibt in ihrem Beitrag zum Care-Regime in der Türkei, dass primär Familie, soziale Netzwerke und Wohltätigkeitsorganisationen Träger der Pflege von Kindern und Angehörigen sind. Unter anderem wirkt sich das Fehlen öffentlicher Kinderbetreuungseinrichtungen auf die Beschäftigungsquote von Frauen (28\%) aus. Daher sieht sie nur in einer Übernahme dieser Aufgaben durch die öffentliche Hand die Möglichkeit, nachhaltig die Gleichstellung von Frauen zu fördern.

Der letzte Beitrag von Berna Zengin Arslan beschäftigt sich mit der Entstehung und Entwicklung der Gülen-Bewegung in der Türkei seit den 1960er-Jahren, ihrer Internationalisierung in den 1990er-Jahren sowie ihrer strategischen Vorgehensweise in der Entsäkularisierung und Islamisierung der Türkei. Dabei konzentriert sie sich vor allem auf die Rolle der Gülen-Schulen, welche nicht nur eine Segregation zwischen den Geschlechtern, sondern vor allem die Förderung von Männerbünden als Träger öffentlichen Wandels etablierten, um säkulare Institutionen unbemerkt zu unterwandern und Konzepte der Moderne umzudeuten.

Das Buch bietet insgesamt einen guten Überblick zur Frauen- und Türkeiforschung. Die einzelnen Beiträge zeichnen systematisch die politischen und gesellschaftlichen Konfliktlinien nach, die die Rechte der Frauen und die Handlungsspielräume der Frauenbewegungen zunehmend begrenzen. Ein analytisches Schlusswort, welches die Beiträge miteinander verknüpft und eine Perspektive für weiterführende Forschungsfragen aufzeigt, hätte das Buch noch abgerundet.

Hürcan Asli Aksoy (Hg.), 2018: Patriarchat im Wandel. Frauen und Politik in der Türkei. Frankfurt/M.: Campus Verlag, 258 S., ISBN 978-3-593-50806-1. 


\title{
Neo-Institutionalismus - Revisited. Bilanz und Weiterentwicklungen aus Sicht der Geschlechterforschung
}

\author{
KARIN LOHR
}

Der vorliegende von Maria Funder herausgegebene Band nimmt eine theoretische Strömung - den soziologischen Neo-Institutionalismus (NI) - in den Blick, die in den letzten Jahren vor allem in der organisationssoziologischen Forschung sehr prominent geworden ist. Die zentrale These des NI ist, dass sich Organisationen an Normen, Erwartungen und Leitbildern ihrer institutionellen Umwelt orientieren, um nicht nur als effizient, sondern auch als legitim zu gelten und damit gesellschaftliche Anerkennung zu erfahren. Dezidiertes Ziel des Handbuches ist es, ,die vorhandenen Schnittstellen zwischen Geschlechterforschung und Neo-Institutionalismus näher auszuloten und Weiterentwicklungen zur Diskussion zu stellen“ (11). Der Band ist inspiriert durch eine Tagung und ein Projekt (gefördert durch die DFG). Die (inklusive Vor- und Nachwort) auf 584 Seiten präsentierten 21 Beiträge des Handbuchs sind allerdings in der vorgegebenen Kürze in keiner Weise angemessen zu würdigen und kritisch zu reflektieren.

Im ersten Teil wird das „Wirkgeflecht“ von Gesellschaft, Organisation und Geschlecht als theoretisches Problem thematisiert. Organisationen werden als Orte der Herstellung oder auch Auflösung von Geschlechterdifferenzen betrachtet und argumentiert, dass deren Einbindung in unterschiedliche institutionelle (und gendered) Felder, in gesellschaftliche Normen- und Wertesysteme sowie in nationalspezifische institutionelle Rahmenbedingungen es ermöglicht zu erklären, warum trotz rhetorischer Modernisierung Geschlechterungleichheit ein zentrales Thema bleibt (Funder/Walder, Hericks/Wobbe, Knoll).

Der zweite Teil des Handbuches setzt sich mit grundlegenden Theoremen des NI auseinander: dem auf Scott zurückgehenden Institutionenbegriff (Nagel/Schulte) Hiß, Horwarth), der prominenten These der Entkopplung von ,talk“ und ,,action“" in Organisationen (u.a. Hericks) und dem Argument, dass Organisationen nicht nur nach Rationalität, sondern auch nach Legitimität streben (u.a. Ranftl). Diese Ansätze werden kritisch hinterfragt und aus geschlechtersoziologischer Perspektive erweitert.

Der dritte Teil greift die unzureichende Thematisierung von handlungsmächtigen und mikropolitisch agierenden Akteur innen im NI auf. Dafür wird auf klassische mikroinstitutionalistische und neuere Ansätze (insbesondere des „skandinavischen Institutionalismus“ zum ,institutional entrepreneur" und zur ,institutional work“) zurückgegriffen. Es wird die Frage aufgeworfen, wie Institutionen in Organisationen überhaupt entstehen und inwiefern sie wandelbar sind (Rybnikova/Lang, Eberher, Trenkmann, Offenberger/Nentwich, Rastetter). Konzepte des „practising gender“, 
des ,,doing gender“ und des ,doing difference“ werden zum Anlass genommen, Strategien des De-Genderings zu diskutieren (Eberher, Trenkmann).

Wandel- und Beharrungstendenzen der vergeschlechtlichten Verfasstheit von Organisationen werden im vierten Teil auch empirisch besprochen. Beispiele hierfür sind u.a. das Auseinanderklaffen von veränderten Männlichkeitsvorstellungen sowie Vereinbarkeitsansprüchen und dem tatsächlichen Verhalten von Vätern (Liebig/Peitz) und die Umsetzung von Diversity-Management Konzepten (Hasse/Mormann). Die Autor_innen zeigen auf, dass in Organisationen Paradoxien auftreten, Entkopplungsprozesse stattfinden, politische Gestaltungsspielräume unterschiedlich genutzt werden können, diskursive Abgrenzungsstrategien verfolgt werden (Amstutz/Wet$z e l$ ) und die De-Thematisierung von Geschlecht vorangetrieben wird, aber dennoch heteronormative Muster und Geschlechterungleichheiten nicht überwunden sind. $\mathrm{Zu}$ diesem Schluss kommt auch Müller in der Re-Interpretation der Befunde des Bandes, wenn sie festhält, dass die „Legitimationsebene in Bewegung gerät“" (561). Als Fazit bleibt festzuhalten, dass die Beiträge des Handbuchs theoretisch-konzeptionell angelegt sind, aber auch empirische Einblicke in verschiedene Themengebiete, die aktuell in der Geschlechterforschung verhandelt werden (Gleichstellungspolitiken, Frauen in Führungspositionen, neue Väter, Vereinbarkeit von Beruf und Familie u.a.) sowie in verschiedene Organisationstypen (ILO, Unternehmen, Hochschulen, Verbände, Feuerwehr u.a.) bieten. Die Beiträge füllen aus geschlechtersoziologischer Perspektive die Lücke zwischen doing gender und konstruktivistischen Ansätzen, die auf Subjekt- und Interaktionsebene argumentieren, und eher strukturellen Ansätzen, die auf die historische Genese von Geschlechterdifferenzen und verfestigte gesellschaftliche Strukturen verweisen. Der Ertrag für die Geschlechterforschung ist, dass die Mechanismen in Organisationen und deren institutionellem Umfeld aufgezeigt werden, die zur Reproduktion von Geschlechterungleichheiten beitragen. Die Überlegungen geben den Blick frei auf das Werden und den Wandel der institutionellen Verfestigung von Geschlechterdifferenzen in Organisation und Gesellschaft. Was den Band besonders macht ist, dass es durchweg gelingt, den NI für die Geschlechterforschung fruchtbar zu machen, Geschlecht als Kategorie in die Konzepte und Analysen des NI einzuschreiben und eine Verschränkung zwischen neo-institutionalistischen Theorien und Gendertheorien zu erreichen. Und mehr noch: Es werden neue theoretische und analytisch-konzeptionelle Ansätze nicht nur für die Geschlechterforschung - besonders was Analysen auf Organisationsebene anbelangt - sondern auch für die Organisationsforschung entwickelt (z.B. bezüglich der Unschärfen im verwendeten Organisationsbegriff, der defizitären Erklärung der Entstehung von dominanten institutionellen Deutungsmustern und der Vernachlässigung von Akteur_innen). Zudem wird der NI, aber auch die Geschlechterforschung durch andere theoretische Perspektiven inspiriert (z.B. durch Bezugnahme auf die Soziologie der Kritik, die Feld- und Praxistheorie Bourdieus, die Akteur-Netzwerk-Theorie von Latour).

Weiterer Diskussionsbedarf besteht m.E. bezüglich der Verwendung des Institutionenbegriffs (der häufig in den Beiträgen nicht explizit gemacht wird), der Themati- 
sierung verschiedener institutioneller Felder und Organisationstypen, der Aufnahme von Intersektionalität und der Überwindung heteronormativer Perspektiven, der weiteren Thematisierung von Macht und Herrschaft und schließlich einer stärkeren kapitalismuskritischen (s. auch Müller) sowie gesellschaftstheoretischen Fundierung.

Maria Funder (Hg.), 2017: Neo-Institutionalismus - Revisited. Bilanz und Weiterentwicklungen aus Sicht der Geschlechterforschung. Baden-Baden: Nomos Verlagsgesellschaft, 584 S., ISBN 978-3-8487-2995.

Alexandra Scheele, Stefanie Wöhl (Hg.)

\section{Feminismus und Marxismus}

\section{CARINA MAIER}

Der Sammelband „Feminismus und Marxismus“ verdeutlicht eine Suche nach emanzipatorischen Potenzialen, mit dem Ziel nach Marx (1844) ,alle Verhältnisse umzuwerfen, in denen der Mensch ein erniedrigtes, ein geknechtetes, ein verlassenes, ein verächtliches Wesen ist" (MEW 1, 385). Die beiden Herausgeberinnen Alexandra Scheele und Stefanie Wöhl geben mit dem Buch anlässlich Karl Marxs 200. Geburtstag einen umfassenden und vor allem differenzierten Überblick über die vielfältigen feministisch-marxistischen Debatten, die breite Rezeptionen von Marx sowie diverse feministische Zugänge vereinen.

Den Einstieg bietet ein historischer Abriss der Auseinandersetzungen um eine strukturelle Analyse des Verhältnisses von Patriarchat und Kapitalismus, die spätestens in den 1970er-Jahren einsetzten und bis heute andauern. Im gesamten Buch, insbesondere im ersten Block „Feministische Kapitalismuskritik“ wird aufgegriffen, was im Klappentext bereits mit Heidi Hartmann angekündigt wird: die Thematisierung der „unglücklichen Ehe“ (9) des Marxismus mit dem Feminismus. So widmen sich viele Debatten der Rolle von Geschlechterverhältnissen in marxistischer Theorie. Frigga Haug eröffnet mit ihrem Beitrag „Selbstveränderung als gesellschaftliche Praxis“ den Raum für grundlegende Kontroversen: Fragen nach dem politischen Subjekt, nach der Rolle subjektiver Erfahrung sowie des universalen Anspruches. Daran anschließend erweitert Ingrid Kurz-Scherf die Grenzen des Marx'schen Denkens, indem sie die „Erneuerung des ,emanzipatorischen Begehrens ${ }^{6}$ in die Perspektive einer feministischen Re-Vision der Kritik der politischen Ökonomie“(61) übersetzt. Ohne dabei die „Aktualität vom Marx’schen Vermächtnis“(61) zu mindern, thematisiert sie mit der Problematisierung nostalgischer Projektionen in die Figur Marx ein „fatales Begehren nach emanzipatorischen Gewissheiten“(60). 
Der zweite Block des Sammelbandes widmet sich den Themen Arbeit, Care und soziale Reproduktion. Beatrice Müller weist in ihrem Aufsatz die permanente und konstitutive Abwertung von Care und Care-Arbeit als eine Konstante im patriarchalen Kapitalismus aus, geht dabei weit über Marx'sche Konzeptionen hinaus, und zeigt dennoch eine begrifflich-theoretische Kontinuität auf. Die „sorge(n)freie Gesellschaft“ (85) funktioniere über strukturelle Dynamiken der Abjektion auf gesellschaftlicher Ebene. Die Negation von menschlicher Verletzbarkeit und Abhängigkeit, die jeglichen Beziehungen inhärent sind, sowie die erweiterte Betrachtung der körperlich-leiblichen Dimension von Care, verdichten die Analyse der theoretischen Begründung der Abwertung von Care. Müller verbindet abstrakte Fragen nach den Formbestimmungen des Wertes mit konkreten Alltagskämpfen von Pflegearbeiterinnen. Den möglicherweise entpolitisierenden Charakter von Werttheoremen wendet sie produktiv, indem sie die „Veränderbarkeit gesellschaftlicher Kräfteverhältnisse verdeutlicht“ (95). Die theoretische Grundlagenarbeit setzt sich in Alexandra Scheeles Aufsatz „Erwerbsarbeit und Emanzipation“ fort, der eine begriffliche Annäherung an den Arbeitsbegriff bietet. Mit der Thematisierung der widersprüchlichen Konstitution von weiblicher* (Un-)Abhängigkeit rückt eine Uneinigkeit feministisch-marxistischer Debatten ins Zentrum: jene der Frage nach "Emanzipation durch Erwerbsarbeit" (115). Scheele begnügt die Leser*innen nicht mit einfachen Antworten, sondern betont die Notwendigkeit der Auseinandersetzungen über die Bedingungen der Arbeit als solche.

Daran bemessen, wie produktiv die Artikel auch über Marx hinausdenken und dennoch die besagte Traditionslinie fortführen, stellt der dritte Block einen Höhepunkt dar, bei dem die Suche nach Emanzipation und Revolution explizit bearbeitet wird. Die eingangs gestellte Frage nach dem politischen Subjekt wird Beitrag für Beitrag geschärft: Aus einer queeren Perspektive sucht der Artikel von Susanne Lummerding nach anti-identitären Subjektkonstitutionen und stellt Fragen nach Ausschlüssen und Grenzziehungen auch innerhalb marxistisch-feministischer Debatten neu. Die Betonung von Identität als „Resultat einer Differenzierung, auf das Kapitalismus grundsätzlich angewiesen ist" (150), bietet einen möglichen antinormativen und antirassistischen Ansatzpunkt für materialistische Analysen. Dem Trugschluss, queere Kämpfe seien bloß kulturell, begegnet die Autorin mit einem radikalen Konzept von queer, verstanden ,als antinormatives, antirassistisches, antisexistisches und kapitalismuskritisches“ (154), und will dieses „für eine Kritik an Identitätslogik produktiv“ (156) nutzen. Passend dazu bietet Hanna Meißner „, Revolutionäre Visionen“, die ausgehend von einer Analyse der Verengung auf das „echte Klassensubjekt“ (160) das Fatale einer Sehnsucht nach dem politischen Subjekt herausarbeitet. Sie betont die Notwendigkeit einer Marx'schen Analyse für eine revolutionäre Transformation, zeigt aber auch die spezifischen Begrenzungen auf.

Der vierte Block „Regulation und Finanzialisierung“ bietet aktuelle Analysen, die ausgehend von regulationstheoretischen Perspektiven, jeweils historisch und räumlich soziale Kämpfe betonen. Im Block „Staatlichkeit und Reproduktionsregime“ bietet Birgit Sauer mit einer Verbindung von neo-marxistischen und post-struktura- 
listischen Staatsperspektiven einen anregenden Beitrag, bei dem weniger Marx als vielmehr Feminismus den Zugang charakterisiert. Sie analysiert die geschlechtsspezifische Gewaltförmigkeit des kapitalistischen Staates intersektional. Mit einer strukturellen Perspektive auf Subjektivierung nähert sie sich der Frage, ,weshalb sich Menschen der staatlichen (Normierungs-)Gewalt unterwerfen“ (209). Durch die Arbeit am Begriff der Sozialen Reproduktion komplementieren Julia Dück und Katharina Hajek die Fragen nach Staatlichkeit. Die Betonung der historischen Kontinuität von Begriffen und die Notwendigkeit der stetigen Kämpfe werden vielfach verdeutlicht, beispielsweise im mehrmaligen Rekurs auf die Hausarbeitsdebatte.

Der Band bietet durch die thematische und theoretische Diversität der Schwerpunktsetzung niederschwellige Möglichkeiten, sich Marx feministisch zu nähern, ihn zu kritisieren, zu erweitern und über ihn hinauszudenken. Die Ansatzpunkte des Marx'schen Werkes reichen von werttheoretischen Überlegungen über den Arbeitsbegriff bis zum Kapitalverhältnis und eröffnen vielfältige Problemfelder, wenngleich explizitere Bezugnahmen auf Rassismus und Antisemitismus die Sammlung noch abrunden würden. Es lohnt sich, dieses Buch als Plädoyer zu lesen, Marx oder zumindest sein Erbe in feministische Debatten einzubeziehen; eine neue innovative Bearbeitung des Feldes Feminismus und Marxismus steht jedoch nicht im Fokus. Optimistisch stimmt ebenso, dass ein gemeinsames Ziel der Autor*innen ersichtlich ist, zumal an unterschiedlichen theoretischen, sich teilweise auch widersprechenden Strängen gearbeitet wird. Jegliche Versuche der Vereinheitlichung dieses Projekts laufen Gefahr, die bemerkenswerte Differenziertheit der Debatten, wie sie im Buch abgebildet ist, zu verlieren. So muss die Suche weitergehen, ,jenseits der einen Wahrheit eines in sich homogenen Kollektivsubjekts, aber immer noch diesseits des kategorischen Imperativ(s), alle Verhältnisse umzuwerfen“ (73).

Alexandra Scheele, Stefanie Wöhl (Hg.), 2018: Marxismus und Feminismus. Weinheim: Beltz Juventa, 250 S., ISBN 978-3-7799-3052-5.

\section{Actors, Institutions, and the Making of EU Gender Equality Programs}

\section{ANNE CRESS}

Petra Ahrens zeigt in ihrer Monographie „Actors, Institutions, and the Making of EU Gender Equality Programs" auf, wie sich im Zuge des Entwurfs und der Adaption des „Fahrplans für die Gleichstellung von Frauen und Männern (2006-2010)“ 
ein grundlegender Wandel in der europäischen Gleichstellungspolitik vollzog. Das von Alison Woodward (2004) identifizierte ,,velvet triangle“ - ein starkes Politiknetzwerk bestehend aus Femokrat_innen, feministischen Wissenschaftler_innen/ Expert_innen sowie frauenbewegten Akteur_innen - scheint seither ebenso Geschichte zu sein wie die Ära der wirkmächtigen gleichstellungspolitischen Aktionsprogramme. Ahrens' Dissertation zeichnet sich durch eine Kombination von soziologischen und politikwissenschaftlichen Forschungsansätzen aus, durch die es ihr gelingt, verborgene Politikprozesse auf bemerkenswerte Weise zu erhellen und deren, dramatic consequences for the constellation of actors in the EU gender equality policy“"(3) offenzulegen.

Datengrundlage der akteurszentrierten qualitativen Studie sind 33 Expert_inneninterviews sowie relevante EU-Dokumente. Die Interviews führte Ahrens im Jahr 2008 mit jenen Akteur_innen, die unmittelbar am sog. Fahrplanprozess (roadmap process) beteiligt waren. In der Einleitung (Kapitel 1) präsentiert die Autorin eine kritische und zugleich fallbezogene Relektüre der Theorie der Strukturierung von Anthony Giddens, die ihr im Weiteren ermöglicht ,the duality - and not the dualism - of agency and structure“"(11) zu untersuchen. Zudem geht sie im ersten Kapitel auf die historischen Meilensteine europäischer Gleichstellungspolitik ein. Im zweiten Kapitel öffnet Ahrens dann die Black Box der vertikalen und horizontalen Politikprozesse. Detailliert schildert sie, wer auf welche Weise und zu welchem Zeitpunkt involviert war, und fasst ihre Erkenntnisse in einer übersichtlichen ,Roadmap policy process timeline“ (97) zusammen. Im Vergleich zu früheren gleichstellungspolitischen Prozessen ist u.a. die geringere Anzahl an unmittelbar Beteiligten sowie deren begrenztes Wissen übereinander auffallend. Der Prozess wurde bis zu dem Zeitpunkt der Verabschiedung des Fahrplans primär von der Kommission koordiniert und kontrolliert. Anschließend dominierten der FEMM-Ausschuss und die Europäische Frauenlobby. Das dritte Kapitel widmet Ahrens der Frage, wie dieser Prozess von den Interviewten rückblickend interpretiert und (re-)konstruiert wird. Für die durchaus heterogenen Deutungen identifiziert sie im vierten Kapitel sodann vier Erklärungsfaktoren: die unterschiedlichen, je nach Politikinstrument variierenden Netzwerke, das Jobrotationssystem und die interne Arbeitsteilung der EUInstitutionen sowie die Terminierung und zeitliche Abfolge der Politikprozesse und -instrumente.

Im fünften und letzten Kapitel führt Ahrens die gewonnenen Erkenntnisse zusammen und erläutert ,the unexpected rollback of EU gender equality programmes“ (238). Mit dem „Fahrplan für die Gleichstellung von Frauen und Männern (20062010)“ schlug die Kommission einen anderen Weg als zuvor ein. Die vorherigen politischen Programme hatten die Vernetzung relevanter Akteur_innen initiiert und eine progressive Gleichstellungspolitik gefördert. Im Unterschied dazu verfügte der neue Fahrplan weder über ein spezielles Aktionsprogramm noch über ein eigenes Budget. Darüber hinaus änderte sich mit der Adaption dieses Politikinstrumentes - so Ahrens zentrale These - ,the whole character of EU gender equality policy- 
making" (6). Der institutionenübergreifende Kooperationsansatz wurde von einer Ghettoisierung der Gleichstellung in den jeweiligen Institutionen abgelöst (246), die bis heute anzuhalten scheint. Die gleichstellungspolitischen Akteur_innen arbeiten auf supranationaler Ebene nicht mehr eng in einem starken Netzwerk zusammen, sondern haben sich in „,competing stakeholders“ (241) verwandelt. Ihre institutionelle Verortung und Rolle gewinnt zunehmend an Bedeutung, wohingegen persönliche Beziehungen in den Hintergrund treten. Ahrens deutet diese Entwicklung nicht als eine Abweichung von den üblichen supranationalen Politikprozessen, sondern vielmehr als eine „Normalisierung“ der Gleichstellungspolitik im Sinne eines ,adjustment to the usual EU rules and routines" (238). Es wurden die üblichen kommissionsinternen ,soft-law“-Prozesse etabliert, zu denen externe Akteure überwiegend keinen Zugang haben. Dass all diese fundamentalen Änderungen nicht in einem „open and 'noisy' conflict” (242) mündeten, führt Ahrens auf die in der EU allgemein vorherrschende Kompromisskultur und deren fatale depolitisierende Effekte zurück. Das gleichstellungspolitische Programm der Kommission konnte so im Zuge des Fahrplanprozesses ohne großen Widerstand zu einer reinen „Symbolpolitik“ - einer bloßen Auflistung laufender gleichstellungspolitischer Aktivitäten - verkümmern. Ahrens' Buch gibt am Beispiel des Fahrplanprozesses einen außergewöhnlich tiefen und detaillierten Einblick in die internen Prozesse der Europäischen Kommission. Es ist daher allen Forscher_innen und Praktiker_innen uneingeschränkt zu empfehlen, die an den Funktionsweisen des politischen Systems der EU im Allgemeinen oder an den Entwicklungen im Feld der europäischen Gleichstellungspolitik im Speziellen interessiert sind.

Petra Ahrens, 2018: Actors, Institutions, and the Making of EU Gender Equality Programs. Basingstoke: Palgrave Macmillan, 305 S., ISBN 978-1-137-57060-4.

Heike Mauer

\section{Intersektionalität und Gouvernementalität. Die Regierung von Prostitution in Luxemburg}

\section{BRIGITTE TEMEL}

Das vorliegende Buch „Intersektionalität und Gouvernementalität. Die Regierung von Prostitution in Luxemburg" von Heike Mauer hat die Prostitution in Luxemburg zwischen 1900 und der Zwischenkriegszeit zum Forschungsgegenstand. Zentral für Mauers theoretischen Zugang sind das Konzept der Intersektionalität sowie das der Gouvernementalität nach Michel Foucault. Durch diese Verbindung zu einer 
integralen Forschungsperspektive untersucht Mauer unterschiedliche historische Quellen, um Prostitutionspolitiken sowie hierfür angewandte Praktiken von unter anderem Regierung, Polizei, Parlament, Öffentlichkeit und Individuen zu analysieren (21).

Nach einer kurzen Einführung in die Thematik sowie der Vorstellung des gewählten Forschungsansatzes leitet Mauer direkt in den theoretischen Teil der Arbeit über.

Hier steht die Auseinandersetzung mit Intersektionalität und Gouvernementalität, mit dem Ziel der Erweiterung der intersektionalen Perspektive durch Foucaults Machtanalytik im Zentrum. Anschließend werden die Genealogie des Begriffs der Intersektionalität sowie die Grundzüge der Debatte um das Konzept nachgezeichnet und die Kontroverse um die Auswahl der Analysegegenstände skizziert. Hierfür wird knapp auf Foucaults Verständnis des Verhältnisses von Sexualität, Rassismus sowie der Bio-Politik der Bevölkerung Bezug genommen. Zum Verhältnis von Intersektionalität und Macht vertritt Mauer die These, dass Intersektionalitätsansätze keinen ausreichend herausgearbeiteten Machtbegriff hätten beziehungsweise mangelnde Machtsensibilität aufweisen würden. Sie verbindet daher die intersektionale Perspektive dieser Arbeit mit Aspekten von Foucaults Machtanalytik - Souveränität, Disziplin und Gouvernementalität.

Im empirischen Teil der Arbeit wird analysiert, wie Prostitution in Luxemburg zwischen 1900 und der Zwischenkriegszeit regiert wurde und wie durch diese Regierung intersektional Macht ausgeübt wurde. Nach einem kurzen historischen Einblick in gesellschaftliche Entwicklungen in Luxemburg um 1900 sowie der Problematisierung von Prostitution zu jener Zeit wird das zur Analyse herangezogene Quellenmaterial vorgestellt. Zwei für die Problematisierung der Prostitution zentrale Themenkomplexe werden näher beleuchtet - die sogenannten Animierkneipen, Orte mit Frauenbedienung, in welchen versteckt der Prostitution nachgegangen wurde, sowie die , wilden Ehen', dem unverheirateten Zusammenleben einer Frau mit einem Mann, welches mit Prostitution assoziiert wurde. Dann werden unterschiedliche „Regierungsweisen“ „der Prostitution fokussiert: Anhand der damaligen Rechtslage und juridischen Regelungen der Prostitution wird die Analyse des Zusammenwirkens von juridischen, disziplinären sowie gouvernementalen Machtlogiken beschrieben (253). Die fremdenpolizeiliche Regierung der Prostitution sowie die Regierung der Prostitution mittels der Sequestrierung, das heißt Inhaftierung geschlechtskranker Frauen und die Reglementierung der Kellnerinnenbedienung als Möglichkeit der Bekämpfung der Prostitution werden ebenfalls analysiert, ebenso wie die Regierung des Selbst von Ehefrauen als Präventionsmaßnahme gegen Prostitution.

Insgesamt ist der Band übersichtlich und nachvollziehbar strukturiert. Mauer besticht durch eine ausführliche sowie gründliche theoretische Argumentation, die überzeugt. Insbesondere in Bezug auf Intersektionalität hat Mauer sehr sorgfältig Ursprünge, Geschichte, Entwicklung sowie Kontroversen und Debatten rund um den Begriff herausgearbeitet. Es fällt allerdings auf, dass Foucaults machttheoretischen Ausführungen in Relation deutlich weniger Raum im Theoriekapitel zuteilwurde. 
Hinsichtlich der konkreten Operationalisierung beziehungsweise Anwendung der entwickelten Analyseperspektive sowie der Auswertungsschritte des Quellenmaterials wäre mehr Transparenz wünschenswert gewesen. So wurde auf die vorgenommene Operationalisierung der Analyseperspektive verhältnismäßig kurz eingegangen und das methodische Vorgehen nicht näher ausgeführt. Im empirischen Teil der Studie beweist Mauer, dass sie es versteht, die von ihr entwickelte Analyseperspektive am Material anzuwenden und es hinsichtlich des Untersuchungsgegenstandes geschickt zu befragen. Unter Einbezug zahlreicher Fallbeispiele wird das Lesen der Ergebniskapitel zu einer spannenden Lektüre.

Mauer sucht mit der vorliegenden Arbeit gleich dreierlei Forschungslücken zu adressieren. Erstens, Wissen über ein bislang unerforschtes Gebiet luxemburgischer Geschichte zu erschließen. Zweitens, die Entwicklung einer intersektionalen und machtanalytischen Analyseperspektive. Drittens, einen Beitrag zur politischen Theorie der Geschlechterverhältnisse zu leisten sowie zur Debatte um Intersektionalität und Macht. Dieses Vorhaben ist Mauer auf jeden Fall gelungen. Weitere Arbeiten, welche die hier erarbeitete integrative Analyseperspektive von Intersektionalität und Machtanalytik nach Foucault aufgreifen, werden hoffentlich folgen - gerne zum Thema der Prostitution.

Heike Mauer, 2018: Intersektionalität und Gouvernementalität. Die Regierung von Prostitution in Luxemburg. Leverkusen-Opladen: Verlag Barbara Budrich, 418 S. ISBN 978-3-8474-2113-9.

Gerald Posselt, Tatjana Schönwälder-Kuntze, Sergej Seitz (Hg.)

\section{Judith Butlers Philosophie des Politischen. Kritische Lektüren}

\section{MAREIKE GEBHARDT}

Der von Posselt, Schönwälder-Kuntze und Seitz edierte Band hat sich vorgenommen, „Butlers vielgestaltige und weitverzweigte Reflexionen im Hinblick auf Fragen der Politik und des Politischen kritisch auszuloten und für die (politische) Philosophie der Gegenwart produktiv zu machen“ (8). Daraus leiten die drei Herausgeber_innen in ihrer gemeinsamen Einleitung drei Dimensionen ab, die das Politische im Denken Butlers umreißen: Erstens muss in der Diskussion des Verhältnisses von Theorie und Politik mit Butler davon ausgegangen werden, dass Theorie(-bildung) eine spezifische Praxisform des Politischen darstellt, die immer schon in soziopolitische Problemlagen, Kräfteverhältnisse und Machtstrukturen eingebettet ist. Zweitens ist Butlers Denken durch eine Kritik der konzeptuellen und normativen Prämissen 
politischer Philosophie gekennzeichnet, die sich gegen ein ,fundamentalistisches Verständnis der klassischen (politischen) Philosophie richtet und stattdessen auf die kontingenten Grundlagen des politischen Denkens verweist. Drittens gilt es nach den Bedingungen, Potenzialen und Praktiken politischer Veränderung zu fragen. Im ersten Teil des Bandes, „Theoretisierungen“, geht es um eine werkimmanente Lektüre, welche die zentralen Argumentationslinien, Ansätze und Begriffe zunächst rekonstruiert und schließlich auch kritisch ausleuchten soll: Hier reflektieren die Herausgeber_innen in Einzelbeiträgen methodologische und erkenntnistheoretische Fragen (Schönwälder-Kuntze), das Verhältnis zwischen Performativität und dem Politischen (Posselt) sowie die Verflechtungen von Ethik, Alterität und Politik (Seitz).

Im zweiten Teil „Normen und Normativierungen“ werden Butlers Überlegungen durch eine Bezugnahme zu anderen Ansätzen geschärft und verteidigt: Die Beiträge konzentrieren sich auf Anerkennung, Heteronormativität, Solidarität sowie Ent-/Unterwerfung. Zunächst bearbeiten Matthias Flatscher und Florian Pistrol die „Normativität in Anerkennungsverhältnissen “(99) und wählen als Gesprächspartner Butlers Axel Honneth. Die Autoren arbeiten die Schwachstellen der Anerkennungsphilosophie Honneths heraus, stellen diese dem Butler'schen Ansatz gegenüber und betonen die Vorteile einer dekonstruktiven Ethik der Anerkennung, die auf die Sozialität normativer Ordnungen ebenso verweist wie auf die Machtasymmetrien in einer ungleichen, d.h. ungerechten, Verteilung von Prekarität. Der zweite Beitrag fokussiert auf Heteronormativität als hegemoniales Konzept: Im Anschluss an die queer-feministischen und postkolonialen Praktiken der Subversion und Mimikry setzen sich María do Mar Castro Varela und Nikita Dhawan mit der Politik gleichgeschlechtlicher Eheschließung auseinander, die zwischen einer „Verfestigung der heteronormativen Ordnung" und ,gegenhegemoniale[n] Artikulationen"(131) oszilliert - und somit sowohl repressiv-konservative als auch subversiv-emanzipatorische Formen annehmen kann. Im Anschluss diskutiert Hannah Meißner die Fallstricke liberaler Subjektkonzeptionen, die in vertrags- und tauschtheoretischer Tradition das Subjekt als souveränen, rationalen und maskulin(isiert)en Entscheidungsträger markieren. Hierbei werden implizite Machtstrukturen wie auch die soziale, kulturelle und historische Einbettung der Subjektwerdung fahrlässig ignoriert - oder durch den Begriff formaler Gleichheit camoufliert. Für Meißner entwirft Butler in ihrer Dekonstruktion des souveränen Subjektbegriffs eine Kontranarration der „Subjektwerdung“, die von Verletzlichkeit und Prekarität als conditio humana erzählt und daraus solidarische Kraft entfaltet. Heike Kämpf widmet sich schließlich Butlers Ausführungen zu Prozessen der Subjektivierung als Unterwerfung (,subjectivation“): In einer detailreichen Rekonstruktion zeigt Kämpf auf, wie Butler im Anschluss an Foucault und Arendt „Entunterwerfung“ als Kritik und Hinterfragung einer „IntelligibilitätsMatrix" (169) versteht, durch die Lebewesen nur unter bestimmten Bedingungen gesehen und gehört werden. Erst Prozesse der Entunterwerfung ermöglichen marginalisierten Subjekten öffentliche und politische Sichtbarkeit. Die Entunterwerfung 
hat für Kämpf daher immer schon einen kritischen, wenngleich nicht notwendig intentionalen, Gestus inne.

Der dritte Teil widmet sich „Visibilitäten und Transformationen“ und untersucht die medien-, körper- und politiktheoretischen Überlegungen Butlers. In den vielschichtigen Beiträgen von Julia Prager und Andreas Oberprantacher werden die Motive des Leidens, der Trauer und der Unsichtbarkeit durch eine Diskussion des Konzepts der ,grievability“ medien- und politiktheoretisch geltend gemacht. Während Prager in ihrer ,politischen Theorie des Medialen“ (189) räumlich-ästhetische Phänomene der Perspektivierung und Verschiebung fokussiert, konzentriert sich Oberprantacher auf die Analyse der Dämonisierungs- und Viktimisierungseffekte, die sich angesichts pejorativer Medieneinsätze im Diskursraum Flucht und Migration einstellen und damit auch festlegen, welche Leben als „,betrauerbar“ gelten können. Zum Abschluss erörtern die Beiträge von Hans-Martin Schönherr-Mann und Gerhard Thonhauser im Dialog mit Butlers Performativitätsbegriff - insbesondere in Rekurs auf dessen Neuauflage im Rahmen von „Notes toward a Performative Theory of Assembly“ (2015) - das politische Potenzial sich im öffentlichen Raum versammelnder Körper. Der Band endet, indem er Butler selbst zu Wort kommen lässt: In zwei ins Deutsche übersetzten Beiträgen werden das Verhältnis von politischer Philosophie und Psychoanalyse ausgelotet bzw. Fragen der Körperlichkeit und der Verletzlichkeit erörtert.

Insgesamt zeigen die Beiträge die Multiperspektivität und Kohärenz des Denkens Butlers auf. Die Beiträge arbeiten die Verbindungen zwischen ihrem Frühwerk und den Post-9/11-Schriften heraus. Dennoch steht die Auseinandersetzung mit Butlers rezenten Arbeiten im Mittelpunkt, weshalb die Begriffe der Prekarität, Trauer und Vulnerabilität in den analytischen Vordergrund rücken. Damit stellt der Band eine der ersten deutschsprachigen Veröffentlichungen in diesem Feld dar, das bislang im englischsprachigen Raum stärkere Aufmerksamkeit erfuhr. Er erweitert den deutschsprachigen Forschungsstand um eine entscheidende Auseinandersetzung mit den späteren Konzepten Butlers.

Wie ein roter Faden zieht sich der Verweis auf die Interdependenz von politischem Denken und ethischem Anspruch durch den Band. Dies hätte durch Querverweise zwischen den Beiträgen noch deutlicher herausgearbeitet werden können und die Kohäsion des Bandes erhöht.

Die Frage der Übersetzung bleibt indes unbeantwortet. Die Mehrheit der Beiträge nutzt die Übersetzung ins Deutsche, mit der problematische Verluste im Translationsprozess verbunden sind. Eine kurze Stellungnahme der Herausgeber_innen zum Umgang - oder eine konsistente Verwendung innerhalb der verschiedenen Beiträge - mit englischsprachigem Original und deutscher Übersetzung wäre wünschenswert gewesen; dies gilt auch für eine durchgängige Verwendung gendersensibler Sprache.

Gerald Posselt, Tatjana Schönwälder-Kuntze, Sergej Seitz (Hg.), 2018: Judith Butlers Philosophie des Politischen. Kritische Lektüren. Bielefeld: transcript. 328 S., ISBN 978-3-8376-3846-2. 


\section{Antifeminismus: Kontextualisierung, Historisierung und Theoretisierung eines aktuellen Phänomens (Sammelrezension)}

\section{ANNETTE HENNINGER}

Angesichts der Mobilisierungserfolge antifeministischer Kampagnen boomen Publikationen zu diesem Thema. Drei Anfang 2018 erschienene Sammelbände beleuchten das Phänomen Antifeminismus aus unterschiedlichen Perspektiven.

Der Band von Juliane Lang und Ulrich Peters untersucht aus sozialwissenschaftlicher Perspektive die beweglichen Schnittstellen zwischen Antifeminismus, Rassismus und Antisemitismus in Deutschland und Österreich. Antifeminismus, so Lang und Peters, trete seit der Jahrtausendwende zunehmend in organisierter Form auf. Der moderne Antifeminismus sehe für Frauen nicht mehr allein die Mutterrolle vor. Er beharre jedoch auf einer wesenhaften Differenz der Geschlechter, was entweder mit der göttlichen Ordnung, unter Berufung auf die Biologie oder mit völkischen Ordnungsvorstellungen begründet werde. Stefanie Mayer, Edma Ajanovic und Birgit Sauer zeigen unter Rekurs auf Laclau und Mouffe, dass die von antifeministischen Akteur*innen in Österreich heraufbeschworene ,Gender-Ideologie' ein leerer Signifikant ist, der diskursive Anschlüsse zu weiteren, anti-egalitären, antipluralistischen und antidemokratischen Diskursen ermöglicht. Gideon Botsch und Christoph Kopke beleuchten die historische Kontinuität des Topos des ,Volkstods' in der extremen Rechten. Kevin Culina arbeitet heraus, wie in der Zeitschrift Compact Verschwörungsdenken, Antifeminismus und Antisemitismus ineinandergreifen. Je zwei Beiträge fokussieren die politische Rechte in Deutschland (Kirsten Achtelik zur Lebensschutz-Bewegung, Patrick Wielowiejski zur politischen Positionierung von Homosexuellen in der AfD) bzw. in Österreich (Elli Scambor und Daniela Jauk zu Antifeminismus im Männerrechts-Diskurs sowie Judith Goetz über deutschnationale Burschenschaften). Jonas Fedders analysiert Antifeminismus als Beispiel für eine moderne, codierte oder auch offen zutage tretende Spielart des Antisemitismus, etwa wenn behauptet wird, die Rockefellers und Rothschilds hätten den Feminismus erfunden. Birge Krondörfer untersucht Kontroversen über geschlechtergerechte Sprache in Österreich, Johanna Lea Illgner Hass-Kampagnen und Silencing im Internet. Am Beispiel der (außer-)schulischen Bildungsarbeit (Vivien Laumann, Katharina Debus) sowie der Beratung für männliche Betroffene sexualisierter Gewalt (Clemens Fobian, Rainer Ulfers) werden die Folgen antifeministischer Diskursintervention für die Praxis beleuchtet. Hierbei werden Tendenzen zur (Re-) Tabuisierung von geschlechtlicher und sexueller Vielfalt und sexualisierter Gewalt diskutiert, aber es wird auch Transparenz über und ein selbstbewusstes Festhalten an eigenen professionellen Standards eingefordert. Zwar wird in dem Band keine einheitliche analytische Perspektive auf den Untersuchungsgegenstand entwickelt. 
Seine Stärke liegt im historisierenden Zugriff auf das Phänomen Antifeminismus sowie im detaillierten empirischen Nachweis der Wahlverwandtschaft von Antifeminismus, Rassismus und Antisemitismus - ein Aspekt, der in anderen Analysen deutlich zu kurz kommt.

Der Band von Gero Bauer, Regina Ammicht Quinn und Ingrid Hotz-Davies basiert auf zwei transdisziplinären Vorlesungsreihen an der Universität Tübingen und vereinigt elf Beiträge aus der Theologie, den Kultur- und Sozialwissenschaften bis zur Neurowissenschaft. Thematische Klammer ist die Frage, wie die vermeintliche ,Natürlichkeit' der Geschlechter kontextbezogen konstruiert wird. Der Band entfaltet seine Stärken dort, wo er das Mantra antifeministischer Debatten widerlegt, die Geschlechterbinarität bzw. die Geschlechterrollen seien evolutionär vorgeprägt, gottgewollt, ,schon immer' so gewesen oder naturgegeben: Miriam Noël Haile nimmt die populäre Jäger- und Sammlerinnen-These aufs Korn, wonach die Geschlechterrollen evolutionsgeschichtlich in der Steinzeit geprägt wurden. Die empirischen Belege hierfür seien dünn; vielmehr sei der Blick auf die Urzeit stark von rückwärtsgewandten Projektionen zeitgenössischer Geschlechterverhältnisse durch bürgerlich-westlich sozialisierte Forscher bestimmt gewesen. Zwei Beiträge hinterfragen die ,Natürlichkeit' von Zweigeschlechtlichkeit: Angelika von Wahl zeichnet den historischen Umgang mit Intersexualität nach. Ab den 1950er-Jahren wurden intersexuelle Neugeborene zwangsoperiert, um ihr geschlechtliches Erscheinungsbild zu vereindeutigen. Selbsthilfegruppen von Intersexuellen und ihren Angehörigen prangerten dies als Menschenrechtsverletzungen an und setzten damit die Bundesregierung erfolgreich unter Druck. 2013 wurde im Personenstandsrecht die Vorgabe gestrichen, das Geschlecht eines Neugeborenen innerhalb von 14 Tagen einzutragen. Ein Highlight des Bandes ist der gut verständliche Beitrag von Marion Müller zur institutionellen Reflexivität der Geschlechtertrennung im Sport. Am Beispiel von Fußball zeigt Müller, wie die vermeintliche Leistungsungleichheit der Geschlechter durch verbandliche Verbote von gemischten Teams und vereinfachte Sonderregeln für Frauen konstruiert wurde. Anhand von Olympiaden zeichnet sie die Schwierigkeiten von Versuchen nach, die Geschlechtszugehörigkeit von Sportlerinnen* eindeutig zu bestimmen. Insgesamt demonstriert der Band überzeugend, dass die vermeintliche ,Natürlichkeit' oder Gottgewolltheit der Geschlechtertrennung erst mit Hilfe androzentrischer Deutungen, rückwärtsgewandter Projektionen und institutionalisierter Regeln hergestellt wird - was als ,Natur' erscheint, ist also in hohem Maße gesellschaftlich konstruiert.

Der von Mieke Verloo herausgegebene politikwissenschaftliche Sammelband verfolgt einen theoriegenerierenden Anspruch, den man bei vielen Publikationen zum Thema leider vermisst. In der Einleitung wählt Verloo den Begriff „opposition to gender+ equality“, um das breite Akteursspektrum in den Blick zu nehmen, das gegen feministische und Gleichstellungspolitiken interveniert, wobei Verloo Geschlechterungleichheit intersektional betrachtet (daher gender+). Ein wichtiges Anliegen des Bandes ist die Analyse der strukturellen Kontexte, in denen sich eine solche Oppo- 
sition entfaltet. Conny Roggeband unterscheidet bei dem aus der US-Bewegungsforschung stammenden Konzept von Movement/Countermovement Dynamics eine mechanische und eine machtanalytisch informierte Variante. Letztere hält sie für weiterführend, da sie von einem Machtvorsprung antifeministischer Akteur*innen ausgeht: Diese könnten sich bei der Verteidigung traditioneller Ungleichheiten auf institutionelle Machtressourcen und etablierte Eliten stützen. Die Wahrscheinlichkeit antifeministischer Gegenmobilisierung steige, wenn feministische Bewegungen moderate Erfolge hätten, gesellschaftliche Gruppen (darunter auch konservative Frauen) ihre Interessen oder ihren Status bedroht sähen oder Eliteakteur*innen sich hiervon Einfluss auf staatliche Politiken versprächen. Verloo stellt ihre Weiterentwicklung von Sylvia Walbys Social Complexity Theory vor. Sie hält die Zentralbegriffe dieses feministisch-systemtheoretischen Zugangs (gesellschaftliche Domänen, Ungleichheitsregime, politische Projekte, Tipping Points, FeedbackSchleifen und Pfadabhängigkeit) für hilfreich zur Analyse von antifeministischen Oppositionsdynamiken. Die empirischen Beiträge untersuchen unterschiedliche Erscheinungsformen von „opposition to gender+ equality“. Niels Spierings zeichnet anhand des European Social Survey Unterschiede im Niveau von Einstellungen zu Geschlechtergleichheit am Arbeitsmarkt und Homosexualität im Zeitverlauf (2004-2010) nach. Einige Beiträge legen den Fokus auf die institutionalisierte Politik (Petra Ahrens zu verdeckter Opposition in der EU-Bürokratie, Elisabeth Holzleithner zur wechselhaften Geschichte der Jurisdiktion des EUGH, Christina Bergqvist, Elin Bjarnegård und Pär Zetterberg zum Konflikt zwischen Klassen- und Geschlechteranliegen in der schwedischen Sozialdemokratie, die zur Ablehnung einer Ausweitung der Vätermonate führte). Andere nehmen das Zusammenspiel institutionalisierter und außerparlamentarischer Akteur*innen in den Blick (Andrea Kriszán und Raluca Maria Popa zu Diskursen über häusliche Gewalt in Mittel- und Osteuropa, David Paternotte zum Manif pour Tous in Frankreich, Ana Miškovska Kajevska zur Reform des Abtreibungsrechts in Mazedonien). Sofia Strid untersucht hate speech im Internet als Erscheinungsform von Geschlechtergewalt mit dem Ziel (männlichen) Machterhalts. Abschließend reflektiert Verloo Erkenntnisgewinne und Lücken des Bandes: Es fehlten Beiträge zu Südeuropa, zu Großbritannien und Deutschland, und intersektionale Dynamiken insbesondere bezüglich der Wechselwirkungen von Geschlecht mit ,race'/Ethnizität blieben unterbelichtet. Zwar gelingt es Verloo nach Ansicht der Rezensentin nicht überzeugend, den Nutzen des Begriffsgewimmels zu demonstrieren, mit dem ihre Social Complexity Theory operiert. Jedoch ist diese Perspektive hilfreich für das Aufspüren analytischer Engführungen der Bewegungsforschung: Verloo attestiert dem Movements/CountermovementsAnsatz die Vernachlässigung nicht bewegungsförmiger Akteur*innen und eine unterentwickelte Kontextreflexion. Sie betont die Kontextualität der politischen und diskursiven Gelegenheitsstrukturen für antifeministische Opposition und hebt die Qualität der Demokratie als zentralen Faktor hervor. Es gelte also, demokratische Institutionen zu stärken, um die Chancen feministischer Projekte zu verbessern. 
Wer einen Einstieg in die Dekonstruktion der ,Natürlichkeit' von Geschlecht sucht, ist mit dem Band von Bauer/Amicht-Quinn/Hotz-Davies gut beraten, der mit anschaulichen Beispielen operiert und auch für die Lehre geeignet ist, allerdings wenig zum Verständnis von Antifeminismus als politisches Phänomen beiträgt. Der Band von Lang/Peters konzentriert sich auf Wahlverwandtschaften zwischen Antifeminismus und Ideologien aus dem konservativen bis rechten Spektrum. Er stellt somit detailliertes Hintergrundwissen über die Akteursgruppen bereit, die (neben dem evangelikalen Spektrum) antifeministische Debatten in Deutschland und Österreich besonders massiv vorangetrieben haben, während im Kontrast z.B. zu Frankreich konservative Katholik*innen eher im Hintergrund agieren. Den größten Erkenntnisgewinn im Hinblick auf eine Theoretisierung des Phänomens leistet der Band von Verloo, der die in der Forschung häufig unreflektiert genutzte Bewegungs-Terminologie hinterfragt (handelt es sich bei Antifeminismus wirklich um eine Bewegung?) und Ansätze aus der Bewegungsforschung systematisch auf Erkenntnisgewinne und Grenzen für die Analyse des Phänomens abklopft. Zudem ist dies das einzige der besprochenen Werke, das die Wechselwirkungen von Antifeminismus mit der Erosion von Demokratie thematisiert. Hier wäre lediglich eine etwas systematischere Fallauswahl mit Blick auf die einbezogenen Länder sowie die von Verloo stark gemachte intersektionale Perspektive wünschenswert gewesen.

Juliane Lang, Ulrich Peters (Hg.), 2018: Antifeminismus in Bewegung: aktuelle Debatten um Geschlecht und sexuelle Vielfalt. Hamburg: Marta Press, 331 S., ISBN 978-3-944442-52-5.

Gero Bauer, Regina Ammicht Quinn, Ingrid Hotz-Davies (Hg.), 2018: Die Naturalisierung des Geschlechts: zur Beharrlichkeit der Zweigeschlechtlichkeit. Bielefeld: transcript, 223 S., ISBN 978-3-8376-4110-3.

Mieke Verloo (Hg.), 2018: Varieties of Opposition to Gender Equality in Europe. London: Routledge, 237 S., ISBN 978-1-38-64961-3. 


\section{ANKÜNDIGUNGEN UND INFOS}

\section{Call for Papers}

\section{Heft 2/2019 der Femina Politica: Umkämpfte Solidaritäten (Arbeitstitel)}

Die Frage nach Solidarität(en) ist aktuell so präsent wie umkämpft. Bereits seit längerer Zeit lassen sich im Zuge neoliberaler Transformationen Tendenzen staatlicher und gesellschaftlicher Entsolidarisierung beobachten, die teils bestehende Ungleichheiten und Differenzsetzungen verschärfen, teils neue (mit) hervorbringen. Mit der voranschreitenden Autoritarisierung im globalen Norden werden diese Politiken radikalisiert: wenn etwa rechtspopulistische Bewegungen und Parteien unter nationalistischen und rassistischen Vorzeichen Solidarität als exkludierende Solidarität rahmen. Zugleich sind jedoch auch neue Praxen der Solidarisierung zu beobachten: Transnationale Solidarisierungen in der Flüchtlingshilfe zeugen hiervon ebenso wie transnationale Bewegungen wie \#BlackLivesMatter, \#NiUnaMenos oder \#MeToo. Und auch im wissenschaftlichen Diskurs setzen sich feministische, queere und antirassistische Ansätze verstärkt (wieder) mit der umkämpften Frage nach Bündnispolitiken, Möglichkeiten kollektiven Handelns und der Formierung von Bewegungen jenseits vorab festgelegter oder singulärer Identitäten auseinander. Während dabei einerseits (neue) feministische Allianzen und Politiken entworfen werden, werden andererseits binnenfeministische Kritiken aktualisiert: So werden eurozentrische und paternalistische Überlegenheitsgesten im Namen von Solidarität kritisiert. Ebenso wird eine Fokussierung (queer-)feministischer Öffentlichkeiten auf Minderheitenrechte und Identitätspolitik beklagt, die neue und vertiefte soziale Ungleichheiten aus dem Blick verloren habe.

Für das Schwerpunktheft „Umkämpfte Solidaritäten“ (Arbeitstitel) möchten wir vor dem Hintergrund gegenwärtiger politischer Entwicklungen auf nationalstaatlicher sowie supranationaler Ebene die Frage nach Solidarität(en) aus feministischer, queerer und postkolonialer Perspektive neu stellen. Dabei interessieren uns zum einen die multiplen geschlechterpolitischen Bedingungen und Effekte im Hinblick auf veränderte Solidaritätsverhältnisse; zum anderen wollen wir danach fragen, was (intersektionale) feministische Solidarität heute angesichts vergeschlechtlichter, rassisierter und klassisierter Ungleichheitsverhältnisse bedeuten kann.

Von besonderem Interesse sind theoriegeleitete empirische sowie theoretische Beiträge zu folgenden Themenbereichen:

- Wie lassen sich in einer globalisierten Welt gesellschaftlicher Zusammenhalt und Strukturen wechselseitiger Solidarität herstellen? Vollzieht sich eine Entwick- 
lung von einer inklusiven zu einer exklusiven Solidarität? Wie stehen sich die Entwürfe ,Europa der Vielen` und ,gemeinsames Europa' gegenüber? Sind verschärfte Grenzregime und die Abwehr von Geflüchteten Ausdruck eines neuen Nationalismus, der keine Solidarität mehr kennt? Wie steht es um die europäische Solidarität nach der Finanz- und Eurokrise? Welche Bedeutung haben diese Verhältnisse für die Entwicklung einer intersektional gedachten geschlechterpolitischen Perspektive?

- Wenn Solidarität als Grundfeste des Sozialstaates begriffen wird, stellt sich die Frage, inwiefern über die Veränderungen des Sozialstaates vergeschlechtlichte, rassisierte und klassisierte Ungleichheiten (re-)produziert werden. Welche Effekte haben Transformationen wie etwa vom Solidarprinzip der Sozialversicherungen (Arbeitslosenversicherung, Rente) zur Privatisierung der Fürsorge für unterschiedliche Bevölkerungsgruppen?

- Wie gestaltet sich im Rahmen aktueller Prozesse der Neoliberalisierung und Autoritarisierung das Verhältnis von Freiheit - Gleichheit - Solidarität angesichts multipler Ungleichheits- und Unterdrückungsverhältnisse? Inwiefern ist Solidarität die Voraussetzung für Freiheit und Gleichheit? Handelt es sich bei internationaler und transnationaler Solidarität um einen Mythos? In welchem Verhältnis stehen Universalität und Partikularität?

- Was sind aktuelle Politiken und Formen queer-feministischer Solidarisierung, die mikropolitische Arenen (wie etwa solidarische Lebens- und Existenzweisen) ebenso berücksichtigen wie institutionelle Zusammenhänge (wie etwa das queerfeministische Potenzial von zivilgesellschaftlichen Akteur_innen, Gewerkschaften, Menschenrechtsorganisationen etc.)?

- Wie steht es um die Zukunft feministischer Bewegungen und Allianzen: Ist ,Frauen*solidarität" ein überholtes Konzept und Ausdruck eurozentrischer, paternalistischer Überlegenheitsgesten oder gibt es spezifische Erfahrungen (der sexuellen Gewalt, der Verantwortlichkeit für Reproduktion, der Ausbeutung des Körpers etc.), die von vielen Frauen* geteilt werden und damit ein Fundament für Solidarität bilden können? Wie könnten Formen ,strategischer Solidarität aussehen?

\section{Abstracts und Kontakt}

Der Schwerpunkt wird inhaltlich von Brigitte Bargetz, Alexandra Scheele und Silke Schneider betreut. Wir bitten um ein- bis zweiseitige Abstracts bis zum 30. November 2018 an brigitte.bargetz@univie.at, alexandra.scheele@uni-bielefeld.de, silke. schneider-ksw@fernuni-hagen.de oder redaktion@femina-politica.de. Die Femina Politica versteht sich als feministische Fachzeitschrift und fördert wissenschaftliche Arbeiten von Frauen* in und außerhalb der Hochschule. Deshalb werden inhaltlich qualifizierte Abstracts von Frauen* bevorzugt. 


\section{Abgabetermin der Beiträge}

Die Schwerpunktverantwortlichen laden auf der Basis der eingereichten Abstracts bis zum 15. Dezember 2018 zur Einreichung von Beiträgen ein. Der Abgabetermin für die fertigen, anonymisierten Beiträge im Umfang von 35.000 bis max. 40.000 Zeichen (inklusive Leerzeichen, Fußnoten und Literatur) ist der 15. März 2019. Die Angaben zu den Autor_innen dürfen ausschließlich auf dem Titelblatt erfolgen. Alle Manuskripte unterliegen einem Double Blind Peer-Review-Verfahren. Pro Beitrag gibt es ein externes Gutachten (Double Blind) und ein internes Gutachten durch ein Redaktionsmitglied aus dem Herausgeberinnenteam. Ggf. kann ein drittes Gutachten eingeholt werden. Die Rückmeldung der Gutachten erfolgt bis spätestens 15. Mai 2019. Die endgültige Entscheidung über die Veröffentlichung des Beitrags wird durch die Redaktion auf Basis der Gutachten getroffen. Der Abgabetermin für die Endfassung des Beitrags ist der 15. Juli 2019.

\section{Offene Rubrik Forum}

Neben dem Schwerpunktthema bietet die Rubrik Forum die Gelegenheit zur Publikation von Originalmanuskripten aus dem Bereich geschlechtersensibler Politikwissenschaft (Beiträge im Umfang von max. 20.000 Zeichen), die zentrale Forschungsergebnisse zugänglich machen oder wissenschaftliche Kontroversen anstoßen. Vorschläge in Form von ein- bis zweiseitigen Abstracts erbitten wir an die Redaktionsadresse redaktion@femina-politica.de. Die endgültige Entscheidung wird auf der Basis des Gesamttextes getroffen. 


\section{Neuerscheinungen}

\begin{abstract}
Ahmed, Nizam (Hg.), 2018: Women in Governing Institutions in South Asia. Parliament, Civil Service and Local Government. Basingstoke: Palgrave Macmillan.
\end{abstract}

Aksoy, Hürcan Aslı (Hg.), 2018: Patriarchat im Wandel. Frauen und Politik in der Türkei. Frankfurt/M., New York: Campus Verlag.

Baxter, Judith, 2018: Women Leaders and Gender Stereotyping in the UK Press. A Poststructuralist Approach. Basingstoke: Palgrave Macmillan.

Behrensen, Maren/Hennig, Linda E./Heimbach-Steins, Marianne, 2018: Gender - Nation - Religion. Ein internationaler Vergleich von Akteursstrategien und Diskursverflechtungen. Frankfurt/M., New York: Campus Verlag.

Chiva, Cristina, 2018: Gender, Institutions and Political Representation. Reproducing Male Dominance in Europe's New Democracies. Basingstoke: Palgrave Macmillan UK.

Coates, Rodney D./Ferber, Abby L./Brunsma, David L., 2018: The Matrix of Race. Social Construction, Intersectionality, and Inequality. Los Angeles: SAGE Publications.

Dackweiler, Regina-Maria/Rau, Alexandra/ Schäfer, Reinhild (Hg.), 2018: Frauen und Armut. Feministische Perspektiven. Opladen: Verlag Barbara Budrich.

Dahlerup, Drude, 2017: Has democracy failed women? Cambridge/Malden: Polity Press.

Davidson-Schmich, Louise K., 2017: Gender, Intersections, and Institutions: Intersectional Groups Building Alliances and Gaining Voice in Germany. Ann Arbor: University of Michigan Press.

Diendorfer, Gertraud/Usaty, Simon (Hg.), 2018: Geschlechtergeschichte und Geschlechterpolitik. Alte und neue Herausforderungen. Wien: Demokratiezentrum.

Diewald, Irmgard, 2018: Männlichkeiten im Wandel. Zur Regierung von Geschlecht in der deutschen und schwedischen Debatte um ,Männer in Kitas'. Bielefeld: Transcript Verlag.

Elias, Juanita/Roberts, Adrienne, 2018: Handbook on the International Political Economy of Gender. Northampton: Edward Elgar Publishing.
Fernandes, Leela (Hg.), 2018: Feminists Rethink the Neoliberal State. Inequality, Exclusion, and Change. New York: NYU Press.

Frevert, Ute, 2017: Die Politik der Demütigung. Schauplätze von Macht und Ohnmacht. Frankfurt/M.: S. Fischer Verlag.

Ganz, Kathrin, 2018: Die Netzbewegung. Subjektpositionen im politischen Diskurs der digitalen Gesellschaft. Opladen: Verlag Barbara Budrich.

Gerhard, Ute, 2018: Frauenbewegung und Feminismus. Eine Geschichte seit 1789. München: Verlag C.H.Beck.

Gerhard, Ute, 2018: Für eine andere Gerechtigkeit. Dimensionen feministischer Rechtskritik. Frankfurt/M., New York: Campus Verlag.

Glaeser, Janina, 2018: Care-Politiken in Deutschland und Frankreich. Migrantinnen in der Kindertagespflege - moderne Reproduktivkräfte erwerbstätiger Mütter. Wiesbaden: Springer VS.

Goetz, Judith/Sedlacek, Joseph Maria/Winkler, Alexander (Hg.), 2018: Untergangster des Abendlandes. Ideologie und Rezeption der rechtsextremen ,Identitären'. Hamburg: Marta Press.

Gruner, Paul-Hermann, 2018: Die suggestive Konfiguration von „Weiblichkeit”. Frauenzeitschriften, Doing Gender und die Kontinuität tradierter Rollenstereotype. Wiesbaden: Springer VS.

Günter, Andrea/Conrady, Claudia/Harth, Elfriede/Holzäpfel, Lena/Löbert, Traude, 2018: Denkwerkstatt Gerechtigkeit. Gerechtere Geschlechterverhältnisse denken und gestalten. Roßdorf: Ulrike Helmer Verlag.

Hark, Sabine/Hofbauer, Johanna, 2018: Vermessene Räume, gespannte Beziehungen. Unternehmerische Universitäten und Geschlechterdynamiken. Berlin: Suhrkamp Verlag.

Hartley, Daniel/Horn-Schott, Mirjam/Olson, Greta/Schmidt, Regina Leonie (Hg.), 2018: Beyond Gender. An Advanced Introduction to Futures of Feminist and Sexuality Studies. London, New York: Routledge. 
Heinemann, Isabel, 2018: Wert der Familie. Ehescheidung, Frauenarbeit und Reproduktion in den USA des 20. Jahrhunderts. Berlin: De Gruyter Oldenburg.

Heitzmann, Daniela/Klein, Uta (Hg.), 2017: Diversity konkret gemacht. Wege zur Gestaltung von Vielfalt an Hochschulen. 2. Auflage. Weinheim: Beltz Juventa.

Hobuß, Steffi/Khiari-Loch, Ina/Maataoui, Moez (Hg.), 2018: Tunesische Transformationen. Feminismus - Geschlechterverhältnisse - Kultur. Tunesisch-deutsche Perspektiven. Bielefeld: Transcript Verlag.

Kahlert, Heike (Hg.), 2018: Gender Studies and the New Academic Governance. Global Challenges, Glocal Dynamics and Local Impacts. Wiesbaden: Springer VS.

Kanyeredzi, Ava, 2018: Race, Culture, and Gender. Black Female Experiences of Violence and Abuse. Basingstoke: Palgrave Macmillan UK.

Kortendiek, Beate/Riegraf, Birgit/Sabisch, Katja (Hg.), 2018: Handbuch Interdisziplinäre Geschlechterforschung. Reihe: Geschlecht und Gesellschaft 65. Wiesbaden: Springer VS.

Krüger-Kim, Helga/Wolf, Laura, 2018: Mutterschaft zwischen Konstruktion und Erfahrung. Aktuelle Studien und Standpunkte. Opladen: Verlag Barbara Budrich.

Lang, Juliane/Peters, Ulrich (Hg.), 2018: Antifeminismus in Bewegung. Aktuelle Debatten um Geschlecht und sexuelle Vielfalt. Hamburg: Marta Press.

Lobban, Rosemary/Luyt, Russell/Welch, Christina, 2018: Diversity in Gender and Visual Representation. London, New York: Routledge.

Löther, Andrea/Riegraf, Birgit, 2017: Gleichstellungspolitik und Geschlechterforschung. Veränderte Governance und Geschlechterarrangements in der Wissenschaft. Opladen: Verlag Barbara Budrich.

Löw, Christine/Volk, Katharina/Leicht, Imke/ Meisterhans, Nadja, 2017: Material turn. Feministische Perspektiven auf Materialität und Materialismus. Opladen: Verlag Barbara Budrich.

Magidimisha, Hangwelani Hope/Khalema, Nene Ernest/Chipungu, Lovemore/Chirimabmowa, Tamuka, 2018: Crisis, Identity and Migration in Post-Colonial Southern Africa. Basel: Springer International Publishing.
Marso, Lori Jo, 2017: Politics with Beauvoir. Freedom in the Encounter. Durham: Duke University Press.

Marx Ferree, Myra, 2018: Feminismen. Die deutsche Frauenbewegung in globaler Perspektive. Frankfurt/M., New York: Campus Verlag.

Messerschmidt, James W./Messner, Michael A./Raewyn, Connell/Martin, Patricia Yancey (Hg.), 2018: Gender Reckonings. New Social Theory and Research. New York City: New York University.

Messner, Elena/Schörkhuber, Eva/Sturm, Peter (Hg.), 2018: Warum feiern: Beiträge zu 100 Jahren Frauenwahlrecht. Wien: Edition Atelier.

Millar, Erica, 2018: Happy Abortions. Mein Bauch gehört mir - noch lange nicht. Berlin: Verlag Klaus Wagenbach.

Millett, Kate, 2018: Sexus und Herrschaft. Die Tyrannei des Mannes in unserer Gesellschaft. Köln: Kiepenheuer \& Witsch.

Mukhopadhyay, Samhita/Harding, Kate, 2017: Nasty Women: Feminism, Resistance, and Revolution in Trump's America. New York: Picador.

Ní Aoláin, Fionnuala/Cahn, Naomi/Haynes, Dina Francesca/Valji, Nahla (Hg.), 2018: The Oxford Handbook of Gender and Conflict. New York: Oxford University Press.

Notz, Gisela, 2018: 50 Jahre 1968. Warum flog die Tomate? Die autonomen Frauenbewegungen der Siebzigerjahre. Entstehungsgeschichte - Organisationsformen - politische Konzepte - Wie geht es weiter? Neu-Ulm: AG Spak Bücher.

Peterson, Helen (Hg.), 2017: Gender in Transnational Knowledge Work. Basel: Springer International Publishing.

Pflücke, Virginia Kimey, 2018: Wenn Hausarbeit bezahlt wird. Der Wandel der Arbeitsbeziehung im Privathaushalt in Spanien und Uruguay. Frankfurt/M., New York: Campus Verlag.

Reusch, Marie, 2018: Emanzipation undenkbar? Mutterschaft und Feminismus. Münster: Verlag Westfälisches Dampfboot.

Robaszkiewicz, Maria, 2017: Übungen im politischen Denken. Hannah Arendts Schriften als Einleitung der politischen Praxis. Wiesbaden: Springer VS. 
Rohde, Achim/Schüler-Springorum, Stefanie/ Von Braun, Christina (Hg.), 2018: National Politics and Sexuality in transregional Perspective. The Homophobic Argument. London, New York: Routledge.

Rousseau, Stéphanie/Morales Hudon, Anahi, 2017: Indigenous Women's Movements in Latin America. Gender and Ethnicity in Peru, Mexico, and Bolivia. New York: Palgrave Macmillan US.

Sauer, Arn T., 2018: Equality Governance via Policy Analysis? The Implementation of Gender Impact Assessment in the European Union and Gender-based Analysis in Canada. Bielefeld: Transcript Verlag.

Sauer, Birgit/Pajnik, Mojca (Hg.), 2017: Populism and the Web. Communicative Practices of Parties and Movements in Europe. London: Routledge.

Schmidt, Francesca, 2018: Netzpolitik. Eine feministische Einführung. Opladen: Verlag Barbara Budrich.

Sedmak, Mateja/Sauer, Birgit/Gornik, Barbara (Hg.), 2017: Unaccompanied Children in European Migration and Asylum Practices. In Whose Best Interests? London: Routledge.

Thimm, Viola (Hg.), 2018: Understanding Muslim Mobilities and Gender. Basel: MDPI.

Thomas, Melanee/Bittner, Amanda (Hg.), 2018: Mothers and Others. The Role of Parenthood in Politics. Vancouver: UBC Press.

Vogel, Lise, 2018: Die Frau im Kapitalismus: Eine feministische Kritik der politischen Ökonomie. Münster: Unrast Verlag.

Volk, Katharina, 2018: Von der Gesellschaftsanalyse zur Utopie. Ein historischer Rückblick auf materialistisch-feministische Theorien. Münster: Westfälisches Dampfboot.

Wilde, Gabriele/Zimmer, Annette/Obuch, Katharina/Panreck, Isabelle-Christine (Hg.), 2018: Civil Society and Gender Relations in Authoritarian and Hybrid Regimes. New Theoretical Approaches and Empirical Case Studies. Opladen: Verlag Barbara Budrich.

\section{Aus Zeitschriften und Sammelbänden}

Ahrens, Petra, 2018: Indirect Opposition: Diffuse Barriers to Gender+ Equality in the European Union. In: Verloo, Mieke (Hg.): Opposing Gender Equality in Europe: Theory, Evidence and Practice. New York: Routledge, 77-97.

Ahrens, Petra, 2018: Qualitative Network Analysis: A Useful Tool for Investigating Policy Networks in Transnational Settings? Methodological Innovations January-April 2018. Open access: http://journals.sagepub.com/ doi/full/10.1177/2059799118769816.

Azam, Hina, 2018: Islamic Feminism between Islam and Islamophobia. In: Journal of Middle East Women's Studies. 14 (1), 124-128.

Bargetz, Brigitte, 2018: Politik und Angst. Oder: homo neuroticus und der Spuk nationaler Souveränität. In: Prokla 190. 48 (1), 73-90.

Bargetz, Brigitte/Freudenschuss, Magdalena, 2018: Umkämpfte Gefühle: Affektives Regieren (in) der multiplen Krise. In: Mesner, Maria/ Mesquita, Sushila (Hg.): Eine emotionale Geschichte: Geschlecht im Zentrum der Politik der Affekte. Wien: Zaglossus (i.E.).

Basham, Victoria M./Catignani, Sergio, 2018: War is Where the Hearth is: Gendered Labor and the Everyday Reproduction of the Geopolitical in the Army Reserves. In: International Feminist Journal of Politics. 20 (2), 153-171.

Bauhardt, Christine/Çağlar, Gülay/Riegraf, Birgit (Hg.), 2017: Ökonomie jenseits des Wachstums - feministische Perspektiven auf die (Post)Wachstumsgesellschaft. Feministische Studien. 35 (2).

Aus Politik und Zeitgeschichte, 2018: (Anti-) Feminismus. 68 (17).

Berghahn, Sabine, 2018: Staatliche Neutralität zwischen religiösem Pluralismus und wohlfeilem Populismus: Ist ein Kopftuchverbot für Richterinnen und Rechtsreferendarinnen verfassungskonform? In: Kritische Justiz. 51 (2), 167-178.

Berghahn, Sabine, 2018: Zeit, das Berliner „Neutralitätsgesetz“ zu ändern! In: Rechtswirklichkeit. Das Blog des Berliner Arbeitskreises Rechtswirklichkeit. Internet: https:// barblog. hypotheses.org/1986.

Deane, Tameshnie, 2018: Sexual Violence and the Limits of Laws' Powers to Alter Behaviour: 
The Case of South Africa. In: Journal of International Women's Studies. 19 (2), 84-103.

Dubravka, Zarkov/Davis, Kathy, 2018: Ambiguities and Dilemmas around \#MeToo: \#ForHow Long and \#WhereTo? In: European Journal of Women's Studies. 25 (1), 3-9.

Eid, Fatima H., 2018: Young Women's Civic Awareness and Public Engagement: A Challenge in a Bahraini Context. In: Journal of International Women's Studies. 19 (2), 197-214.

Essyad, Anouk, 2018: Decolonial and PostcoLonial Approaches: a Dialogue. In: Nouvelles Questions Féministes. 37 (1), 170-175.

Fuchs, Gesine, 2018: Sozialpolitische Wirkungen von "Workfare“ im Wohlfahrtsstaat. ZEUGS - Working Paper No. 10|2018. Internet: www.uni-muenster.de/ZEUGS/publikationen/ workingpapers/index.html.

Garcia, Anne-Laure/Dietzsch, Ina, 2018: Stillen als wissenschaftlicher Gegenstand. Epistemologische Überlegungen zur Untersuchung einer "natürlich sozialen Tatsache“ am Beispiel des medizinischen Diskurses. In: Gender. Zeitschrift für Geschlecht, Kultur und Gesellschaft. 10 (1), 100-114.

Gebhardt, Mareike, 2018: Zwischen Repräsentation und (Real-) Präsenz. Populistische Intervalle und demokratische Temporalstrukturen aus politiktheoretischer Perspektive. In: Diskurs. Die Zeit des Politischen und die Politik der Zeit. Heft 3, 21-44.

Günther, Jana, 2017: Body Politics revisited. Feminismus und Widerstand. In: INDES - Zeitschrift für Politik und Gesellschaft. (4), 83-91.

Guerrina, Roberta/Haastrup, Toni/Wright, Katharine A.M./Masselot, Annick/Heather, MacRae/Cavaghan, Rosalind, 2018: Does European Union Studies have a Gender Problem? Experiences from Researching Brexit. In: International Feminist Journal of Politics. 230 (2), 252-257.

Höhmann, Daniel, 2017: Frauen in politischen Spitzenämtern. Die Ernennung von weiblichen Ministern in die Landeskabinette der deutschen Bundesländer. In: Zeitschrift für Vergleichende Politikwissenschaft. 11 (3), 391 416.

Howell, Alison, 2018: Forget "Militarization": Race, Disability and the "Martial Politics" of the Police and of the University. In: International Feminist Journal of Politics. 20 (2), 117-136.
Jouët, Josiane, 2018: Digital Feminism. Questioning the Renewal of Activism. In: Journal of Research in Gender Studies. 8 (1), 133-157.

Kreissl, Katharina/Sauer, Birgit, 2017: Feminist Political Institutionalism. Ein Beitrag zum Verständnis von Macht und Herrschaft im Geschlechterverhältnis. In: Funder, Maria (Hg.): Neo-Institutionalismus - Revisited. Bilanz und Weiterentwicklungen aus Sicht der Geschlechterforschung. Baden-Baden: Nomos, 525-550.

Lang, Sabine, 2017: Wider den Genderismus. In: Milbradt, Björn/Biskamp, Floris/Albrecht, Yvonne/Kiepe, Lukas (Hg.): Ruck nach rechts? Rechtspopulismus, Rechtsextremismus und die Frage nach Gegenstrategien. Opladen: Barbara Budrich Verlag, 107-118.

Leidinger, Christiane/Elberskirchen, Johanna, 2018: Radikale Feministin und unbeugsame Streiterin für das demokratische Wahlrecht. In: Journal Netzwerk Frauen- und Geschlechterforschung NRW. Heft 42, 36-39.

Mendes, Kaitlynn/Ringrose, Jessica/Keller, Jessalynn, 2018: \#MeToo and the Promise and Pitfalls of Challenging Rape Culture through Digital Feminist Activism. In: European Journal of Women's Studies. 25 (2), 236-246.

Mihăilă, Ramona/Gregova, Elena/Janoskova, Katharina/Kolencik, Juraj/Arsene, Anne Marie, 2018: The Instrumental Function of Gendered Citizenship and Symbolic Politics in the Social Construction of Labor Rights for Migrants. In: Journal of Research in Gender Studies. 8 (2), 127-136.

Minto, Rachel/Mergaert, Lut, 2018: Gender Mainstreaming and Evaluation in the EU: Comparative Perspectives from Feminist Institutionalism. In: International Feminist Journal of Politics. 20 (2), 204-220.

Power, Nina, 2018: Der verführte Feminismus. In: Blätter für deutsche und internationale Politik. Heft 3, 59-68.

Rao, Nitya/Cagna, Paola, 2018: Feminist Mobilization, Claims Making and Policy Change. An Introduction. In: Development and Change. 49 (3), 708-714.

Rössl, Ines, 2018: Wahlrecht für Migrantinnen! 100 Jahre Frauenwahlrecht - Für wen immer noch nicht? In: Hense-Lintschnig, Philipp/ Purth, Valerie/Sagmeister, Maria/Wieser, Nikolaus (Hg.): Autoritäre Tendenzen im Recht. 
Die Zeitschrift für Kritik - Recht - Gesellschaft. Ausgabe 1, 70-76.

Runyan, Anne Sisson, 2018: Decolonizing Knowledges in Feminist World Politics. In: International Feminist Journal of Politics. 20 (1), 3-8.

Scheele, Alexandra, 2018: Prekarität und Prekärsein als Normalzustand? Überlegungen zu einer Zeitdiagnose. In: Baer, Susanne/ Sacksofsky, Ute (Hg.): Autonomie im Recht - Geschlechtertheoretisch vermessen. Baden-Baden: Nomos, 361-372.

Scheele, Alexandra/Wöhl, Stefanie, 2018: Feminism Confronts Marxism. In: Global Dialogue. 8 (1), 36-37.

Seneviratne, Prajna, 2018: Marxist Feminism Meets Postcolonial Feminism in Organizational Theorizing: Issues, Implications and Responses. In: Journal of International Women's Studies. 19 (2), 186-196.

Spehar, Andrea, 2018: The Pursuit of Political Will: Decision Makers' Incentives and Gender Policy Implementation in the Western Balkans. In: International Feminist Journal of Politics. 20 (2), 236-250.

Thompson, Sharon/Hayes, Lydia/Newman, Daniel/Pateman, Carole, 2018: The Sexual Contract 30 Years on: A Conversation with $\mathrm{Ca}-$ role Pateman. In: Feminist Legal Studies. 26 (1), 93-104.

Wessels, Janna, 2018: Feministische Herausforderungen an das Flüchtlingsrecht: von der zweiten zur dritten Welle. In: Gender. Zeitschrift für Geschlecht, Kultur und Gesellschaft. 10 (2), 18-31.

Wilde, Gabriele, 2018: Plädoyer für einen rechtlichen Schutz des Kampfes um Autonomie. In: Baer, Susanne/Sacksofsky, Ute (Hg.): Autonomie im Recht - Geschlechtertheoretisch vermessen. Baden-Baden: Nomos, 147156.

Wilde, Gabriele/Bomert, Christiane, 2018: Geschlechterforschung in der Politikwissenschaft: Feministische Positionen, Debatten und aktuelle Entwicklungen. In: Kortendiek, Beate/Riegraf, Birgit/Sabisch, Katja (Hg.): Handbuch Interdisziplinäre Geschlechterforschung. Reihe: Geschlecht und Gesellschaft 65. Wiesbaden: Springer VS.

Winkel, Heidemarie, 2018: Fremdheit und Geschlecht. Koloniale Wissensbestände und dekoloniales Denken. In: Journal Netzwerk Frauen- und Geschlechterforschung NRW. Heft 41, 28-35. Internet: https://www.netzwerk-fgf.nrw.de/fileadmin/media/media-fgf/ download/publikationen/netzwerk_fgf_journal_41_171214_f_web.pdf.

Zimmer, Annette/Priller, Eckhard/Paul, Franziska, 2018: Karriere im Nonprofit-Sektor? Arbeitsbedingungen und Aufstiegschancen von Frauen. ZEUGS - Working Paper - Special Issue. Internet: https://www.uni-muenster.de/ ZEUGS/publikationen/workingpapers/index. html. 


\section{AUTOR INNEN DIESES HEFTES}

Abels, Gabriele, Prof. Dr., Jean-Monnet-Professorin mit dem Schwerpunkt vergleichende Politikwissenschaft und Europäische Integration, Institut für Politikwissenschaft an der Universität Tübingen, Mitherausgeberin der Femina Politica. Arbeitsschwerpunkte: Demokratisierung der EU, Rolle von Regionen und Parlamenten, Gender-Forschung zur EU, Integrationstheorien. gabriele.abelsquni-tuebingen.de

Ahrens, Petra, Dr. phil., Marie-Sklodowska-Curie-Fellow an der Universität Antwerpen (Belgien) mit dem Forschungsprojekt „Effects of Institutional Change on Participatory Democracy and the Involvement of Civil Society Organisations" (DemocInChange), Mitherausgeberin der Femina Politica und des European Journal of Politics and Gender (EJPG). Arbeitsschwerpunkte: Gleichstellungspolitik in der Europäischen Union, Gender Mainstreaming, soziale Bewegungen, Arbeitsmarkt- und Sozialpolitik. petra.ahrensQuantwerpen.be

Baumgartinger, Persson Perry, Mag. Dr., Trans Studies/Angewandte Sprachwissenschaft/Sozialgeschichte, Senior Scientist am Programmbereich Zeitgenössische Kunst und Kulturproduktion des universitätsübergreifenden Kooperationsschwerpunktes Wissenschaft und Kunst (Paris Lodron Universität Salzburg \& Universität Mozarteum Salzburgl sowie externer Lektor, Trainer \& Coach. Arbeitsschwerpunkte: Kritische Diskursanalyse, Kritisches Diversity, Trans--Arts.

Blome, Agnes, Dr., wissenschaftliche Mitarbeiterin am Arbeitsbereich Vergleich mit Schwerpunkt Deutschland und Frankreich am Otto-Suhr-Institut für Politikwissenschaft der Freien Universität Berlin und Mitherausgeberin der Femina Politica. Arbeitsschwerpunkte: Vergleichende Wohlfahrtssstaatsforschung, Familienpolitik, Ungleichheit und politische Repräsentation von Frauen. agnes.blomelafu-berlin.de

Cress, Anne, M.A., Doktorandin am Institut für Politikwissenschaft der Universität Tübingen. Arbeitsschwerpunkte: Politische Theorie, Feministische Theorie, Repräsentations- und Partizipationsforschung, Care-Ethik. anne.cressduni-tuebingen.de

Davidson-Schmich, Louise K., Professorin für Politikwissenschaften an der University of Miami, Coral Gables, Florida, USA. Autorin von .,Gender Quotas and Democratic Participation: Recruiting Candidates for Elective Offices in Germany” (Ann Arbor, 2016) und Herausgeberin von „Gender, Intersections, and Institutions: Intersectional Groups Building Alliances and Gaining Voice in Germany" (Ann Arbor, 2017). davidsonamiami.edu

Exo, Mechthild, Dr. rer.pol., Hochschule Emden/Leer, Fachbereich Soziale Arbeit und Gesundheit. Arbeitsschwerpunkte in Lehre und Forschung: Transkulturalität, Anti-Rassismus, internationale Entwicklungen, Dekolonialisierung des Wissens, feministisch-dekoloniale Wissenschaftskritik, Jineolojî, Friedens- und Konfliktforschung. mechthild.exolahs-emden-leer.de

Fiig, Christina, Ph.D., Associate Professor, political scientist and gender scholar, Section for European Studies, Aarhus University, Denmark. Areas of expertise: Gender and politics, democracy, media and the public sphere in a perspective of intersectionality, women's enfranchisement. cfiiglacas.au.dk

Gebhardt, Mareike, Dr., Department für Sozialwissenschaften und Philosophie, Institut für Soziologie an der FAU Erlangen-Nürnberg. Arbeits- und Forschungsschwerpunkte: Politische Theorie, Demokratietheorie, Alterität und Fremdheit, Protest und Widerstand, Migrations- und Fluchtforschung.

Günther, Jana, promovierte Dipl. Soz., wissenschaftliche Mitarbeiterin an der Professur für Makrosoziologie, TU Dresden. Arbeitsschwerpunkte: Soziale Bewegungen und Protestforschung, Sozialstrukturanalyse und soziale Ungleichheit sowie klassische feministische Theorie. jana.guentherdutu-dresden.de 
Heidkamp, Birte, M.A., leitende Koordination des E-Learning Zentrums der Hochschule RheinWaal. Arbeitsschwerpunkte: Qualitative Bildungs- und Lernforschung, Medienpädagogik, Diversität im digitalen Zeitalter, Semiotik des Lernens, e-Didaktik.

Henninger, Annette, Dr. phil., seit 2009 Professorin für Politik und Geschlechterverhältnisse mit Schwerpunkt Sozial- und Arbeitspolitik an der Philipps-Universität Marburg. Arbeits- und Lehrschwerpunkte: Politik und Geschlechterverhältnisse, Politische Ökonomie, Demokratie und Geschlecht.

Jenichen, Anne, Dr., Lecturer in Politics and International Relations, Aston Centre for Europe und School of Languages and Social Sciences an der Aston University, Birmingham, Großbritannien. Arbeitsschwerpunkte: Politischer Einfluss internationaler Normen und Organisationen, europäische Menschenrechtspolitik, Rechte benachteiligter Gruppen, insbesondere von Frauen und religiösen Minderheiten. a.jenichendaston.ac.uk

Kassai, Jasmin, derzeit in Ausbildung zur Kinder- und Jugendpsychiaterin und stv. Obfrau des Vereins „Flucht nach Vorn - Verein zur Förderung von Kindern und Jugendlichen mit Fluchterfahrung" in Wien.

Kergel, David, Dr., M.A., erstes Staatsexamen, wissenschaftlicher Mitarbeiter im Projekt digitaLe an der Hochschule Rhein-Waal. Arbeitsschwerpunkte: Qualitative Bildungs- und Lernforschung, Medienpädagogik, Diversität im digitalen Zeitalter, angewandte Epistemologie und Medien- sowie Internetethik, qualitative Evaluationsforschung.

Kletzing, Uta, Dr., Politikwissenschaftlerin, derzeit Referentin im Forum Politik und Gesellschaft in der Friedrich-Ebert-Stiftung in Berlin. Arbeitsschwerpunkte: Frauen in Führungspositionen, u.a. in der Politik; gleichstellungspolitische Strategien, u.a. Paritätsgesetz und Gender Mainstreaming; Personal-, Führungskräfte- und Organisationsentwicklung. maildutakletzing.de

Lichtenberger, Hanna, Politikwissenschaftlerin und Historikerin. Lektorin für Internationale Politische Ökonomie am Institut für Politikwissenschaft der Universität Wien.

Lohr, Karin, Prof. Dr., Lehrbereich Soziologie der Arbeit und Geschlechterverhältnisse am Institut für Sozialwissenschaften an der Humboldt-Universität zu Berlin. Lehr- und Forschungsschwerpunkte: Arbeits- und Organisationssoziologie, Geschlechterforschung, Qualitative Methoden.

Maier, Carina, B.A. B.Sc., Politikwissenschaft, Studierende und Forschungsassistentin am Institut für Internationale Entwicklung an der Universität Wien. Arbeitsschwerpunkte: Feministische Theorie, Antifeminismus, Ideologiekritik.

Mushaben, Joyce Marie, Ph.D., Curators' Distinguished Professor of Comparative Politics und ehemalige Direktorin des Institute for Women's \& Gender Studies an der University of MissouriSt. Louis. Forschungsstipendien der Fulbright Commission, Alexander von Humboldt Stiftung, Ford Foundation und des DAAD, Mitglied im wissenschaftlichen Beirat der Femina Politica. Arbeitsschwerpunkte: Gender and Leadership, deutsche Identitäten (Ost/West/multikulti), Migrations- und Asylpolitik sowie vergleichende Sozialpolitik in den USA und Europa. mushabendumsl. edu

Petö, Andrea, Professorin am Department of Gender Studies an der Central European University, Budapest. Arbeitsschwerpunkte: Vergleichende europäische Sozial- und Geschlechtergeschichte, Gender und Politics, Frauenbewegungen, qualitative Methoden, Oral History und Holocaust. petoadceu.edu

Röhner, Cara, Promotion mit einer Arbeit zu gesellschaftlichen Ungleichheitsverhältnissen und Verfassungsrecht an der Universität Frankfurt/Main, derzeit Rechtsreferendarin am Landgericht Frankfurt/Main. Arbeitsschwerpunkte: Rechtstheorie, Geschlechterverhältnisse und Recht, kritische Sicherheitsforschung. roehnerdjur.uni-frankfurt.de

Rotino, Isabella Sophie, Volljuristin, LL.M., promoviert im Bereich der rechtlichen Geschlechterverhältnisse und ist wissenschaftliche Mitarbeiterin am Lehrstuhl für Gender im Recht der FernUniversität in Hagen. Arbeitsschwerpunkte: Antidiskriminierungsrecht, Menschenrechte und deren Umsetzung, kritische Kriminologie. 
Ruf-Uçar, Helin, Dr. phil., Politikwissenschaftlerin. Arbeitsschwerpunkte: Geschlechterbasierte Gewalt gegen Frauen, Implementierung von Geschlechtergleichstellungsnormen, Frauenbewegungen in der Türkei.

Temel, Brigitte, M.A., Gender Studies, externe Lektorin an der Universität Wien. Arbeitsschwerpunkte: Feministische Theorie, Queere Theorie, Sexarbeit. brigitte.temeldunivie.ac.at

Wischnewski, Alex, M.A., Politikwissenschaft, Mitbegründerin der Plattform Keine Mehr, Referentin für feministische Politik für die Fraktion DIE LINKE im Bundestag. Arbeitsschwerpunkte: Gewalt gegen Frauen, Care, Marxismus-Feminismus. keineeinzigemehrdgmail.com 